\title{
pH-dependent chloride transport by pseudopeptidic cages for the selective killing of cancer cells in acidic microenvironments
}

\author{
Lucía Tapia, ${ }^{[a]}$ Yolanda Pérez, ${ }^{[b]}$ Michael Bolte, ${ }^{[c]}$ Josefina Casas, ${ }^{[a, d]}$ Jordi Solà, ${ }^{[a]}$ Roberto Quesada ${ }^{[e]}$ \\ and Ignacio Alfonso*[a]
}

\begin{abstract}
Acidic microenvironments in solid tumors is a hallmark of cancer. Inspired by that, we designed a family of pseudopeptidic cage-like anionophores displaying $\mathrm{pH}$-dependent activity. When protonated, they efficiently bind chloride anion as shown by NMR titration in aqueous acetonitrile. They also transport chloride through lipid bilayers (ISE experiments in POPC liposomes), being the anionophoric properties improved at acidic $\mathrm{pH}$, which suggests an $\mathrm{H}^{+} / \mathrm{Cl}^{-}$symport mechanism. NMR studies in DPC micelles demonstrate the ability of the cages to bind chloride within the lipid phase. Moreover, the corresponding affinity and the chloride exchange rate with the aqueous bulk solution are improved when the $\mathrm{pH}$ is lowered. These results offer insights into the process at the molecular level. This behavior induces an increased cytotoxicity towards lung adenocarcinoma cells in the $\mathrm{pH}$ conditions mimicking those of the solid tumors. Besides, all these properties are finely tuned by the nature of the side chains of the cages, namely the external decoration of the molecules that modulates their lipophilicity and potential interactions with the cell membrane. Our study paves the way towards using $\mathrm{pH}$ as a parameter to control the selectivity of cytotoxic ionophores as anti-cancer drugs.
\end{abstract}

The accurate control of local $\mathrm{pH}$, with specific values in the different cellular compartments and organelles, is essential for the correct function of living cells. ${ }^{[1]}$ Specifically, tumor tissues are characterized by a reverse $\mathrm{pH}$ gradient compared to normal tissues, with a slightly basic intracellular $\mathrm{pH}\left(\mathrm{pH}_{\mathrm{i}}\right)$ and an acidic extracellular $\mathrm{pH}\left(\mathrm{pH}_{\mathrm{e}}\right)$, as a result of the altered cancer cell metabolism. ${ }^{[2]}$ This $\mathrm{pH}$ pattern allows cancer cells to escape from apoptosis, ${ }^{[3]}$ as well as to promote cell migration and metastasis. ${ }^{[4]}$ Accordingly, the design of drugs able to specifically work in the acidic microenvironment around the solid tumors has been suggested as a putative mechanism to improve selectivity in cancer chemotherapy. ${ }^{[5]}$ Small molecule ionophores have been

\footnotetext{
[a] L. Tapia, Dr. J. Casas, Dr. J. Solà and Dr. I. Alfonso Department of Biological Chemistry, IQAC-CSIC Jordi Girona, 18-26, 08034 Barcelona (Spain). E-mail: ignacio.alfonso@iqac.csic.es

[b] Dr. Y. Pérez NMR Facility, IQAC-CSIC Jordi Girona, 18-26, 08034 Barcelona (Spain).

[c] Dr. M. Bolte

Institut für Anorganische Chemie, J.-W.-Goethe-Universität Max-von-Laue-Str.7 60438 Frankfurt/Main (Germany)

[d] Dr. J. Casas CIBER Enfermedades Hepaticas y Digestivas (CIBEREHD)

[e] Dr. R. Quesada

Departamento de Química, Facultad de Ciencias, Universidad de Burgos, 09001 Burgos (Spain)
}

recently proposed as cancer therapeutics, since their ability to transport ions through cell membrane can upset cellular homeostasis, alter membrane polarization state and impact intracellular $\mathrm{pH}$ levels, eliciting cytotoxic effects. ${ }^{[6]}$ Despite very potent anionophores with biological activity have been reported, ${ }^{[7]}$ the selectivity toward tumors or cancer cells is an important but still unaddressed issue. ${ }^{[8]}$ Thus, we envisioned the possibility to design small peptide-like receptors for chloride that could show $\mathrm{pH}$-modulated affinity and transmembrane transport abilities, ${ }^{[9]}$ with the aim to display an enhanced cytotoxicity in acidic environments. To that, we decided to exploit the structure of pseudopeptidic tripodal cages that had shown a very selective chloride binding when protonated, ${ }^{[10,11]}$ and good abilities to transport this anion through artificial lipid bilayers. ${ }^{[11]}$ In order to tune the physicochemical properties and the potential interactions with the cell membrane, we considered different aromatic side chains deriving from naturally occurring Phe, Tyr and Trp, as well as the non-natural O-Me-Tyr and 4-F-Phe (compounds 1a-e in Figure 1).

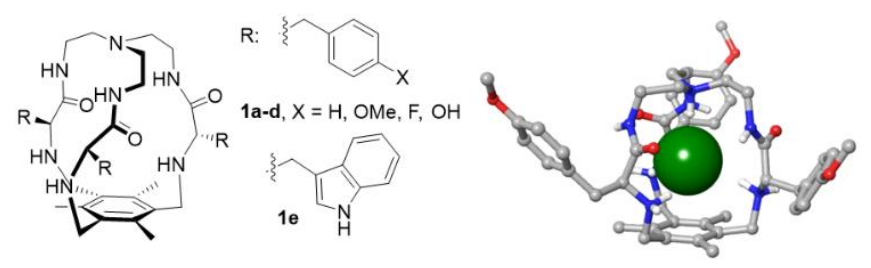

Figure 1. Chemical structure of the pseudopeptidic cages 1a-e and solid state structure of the $\mathbf{1 b} \cdot 4 \mathrm{HCl}$ salt (X-ray diffraction) with the encapsulated chloride in CPK. Additional chloride counterions, solvent molecules and non-polar hydrogen atoms have been omitted for clarity.

The pseudopeptidic cages were prepared following a modification of the previously reported methodology, ${ }^{[11]}$ and experimental details are provided in the Electronic Supporting Information (ESI). All the cages were accurately characterized by spectroscopic techniques and, for two of them, the corresponding crystal structures of the tetra- $\mathrm{HCl}$ salts were resolved by $\mathrm{X}$-ray diffraction. In these two examples (see $\mathbf{1 b}$ in Figure 1 and $\mathbf{1 d}$ in Figure S39 at the ESI) one of the chloride counterions is tightly bound inside the cavity of the cage through strong $\mathrm{H}$-bonding interactions, as we have previously observed for related hosts. ${ }^{[10,11]}$ These solid-state structures supported the ability of the protonated systems to efficiently encapsulate a chloride anion. We also studied the binding properties of the cages by NMR titration of their protonated forms with $\mathrm{TBACl}$ in aqueous acetonitrile (Table 1). 
Table 1. Chloride affinity $\left(\log K_{1: 1}, \log K_{1: 2}, \mathrm{BC}_{50}{ }^{\circ}\right)$, hydrophobicity (calculated $\log P, \mathrm{HPLC}$ retention time), chloride efflux rates in model liposomes (\%Cl. $\mathrm{s}^{-1}$, at different $\left.\mathrm{pH}_{\mathrm{i}} / \mathrm{pH}_{\mathrm{e}}\right)$ and MTT cytotoxicity in $\mathrm{A} 549$ cell lines $\left(\mathrm{IC}_{50}\right.$ in $\mu \mathrm{M}$ at different external $\left.\mathrm{pH}\right)$ for the cages 1a-e.

\begin{tabular}{|c|c|c|c|c|c|c|c|c|c|c|c|}
\hline \multirow{2}{*}{ cage } & \multirow{2}{*}{$\begin{array}{l}\log K_{1: 1} \\
\left(\mathrm{M}^{-1}\right)^{[a]}\end{array}$} & \multirow{2}{*}{$\begin{array}{l}\log K_{1: 2} \\
\left(\mathrm{M}^{-1}\right)^{[a]}\end{array}$} & \multirow{2}{*}{$\mathrm{BC}_{50^{\circ}}(\mu \mathrm{M})^{[\mathrm{b}]}$} & \multirow{2}{*}{$\log P^{[c]}$} & \multirow{2}{*}{$t_{R}(\min )^{[d]}$} & \multicolumn{3}{|c|}{ Chloride efflux rate $\left(\% \mathrm{Cl} \cdot \mathrm{s}^{-1}\right), \mathrm{pH}_{\mathrm{i}} / \mathrm{pH}_{\mathrm{e}}$} & \multicolumn{3}{|c|}{ Cytotoxicity to $\mathrm{A} 549, \mathrm{IC}_{50}(\mu \mathrm{M})$} \\
\hline & & & & & & $7.2 / 7.2$ & $6.2 / 7.2$ & $6.2 / 6.2$ & $\mathrm{pH}_{\mathrm{e}} 7.5$ & $\mathrm{pH}_{\mathrm{e}} 7.1$ & $\mathrm{pH}_{\mathrm{e}} 6.2$ \\
\hline $1 a$ & $4.01(8)$ & $2.2(2)$ & $96 \pm 17$ & 3.90 & 8.017 & 0.092 & 0.091 & 0.159 & $60 \pm 4$ & $60 \pm 3$ & $55 \pm 5$ \\
\hline $1 b$ & $3.7(1)$ & 2.2 & $198 \pm 44$ & 3.63 & 8.431 & 0.039 & 0.055 & 0.078 & $145 \pm 35$ & $118 \pm 16$ & $95 \pm 25$ \\
\hline $1 c$ & $3.82(3)$ & $2.2(1)$ & $148 \pm 10$ & 4.31 & 9.435 & 0.121 & 0.151 & 0.198 & $166 \pm 35$ & $58 \pm 10$ & $29 \pm 4$ \\
\hline $1 d$ & n.d. $[\mathrm{e}]$ & n.d. [e] & n.d. [e] $^{-}$ & 2.81 & 5.067 & 0.059 & $0.1^{[f]}$ & $0.16^{[f]}$ & $>200$ & $>200$ & $>200$ \\
\hline $1 e$ & $3.40(3)$ & $2.1(1)$ & $380 \pm 24$ & 4.04 & 8.148 & $0.14^{[\mathrm{f}]}$ & $0.05^{[f]}$ & $0.128^{[f]}$ & $>200$ & $>200$ & $\sim 170$ \\
\hline
\end{tabular}

[a] By NMR titration, standard deviation on the last significant figure in parenthesis. [b] As defined in ref. [12]. [c] Calculated using VCCLab software with the cages as free amines. [d] Retention time in HPLC C18 reverse phase (see ESI for details). [e] Partial precipitation precluded the accurate fitting of the titration data. [f] The numerical values must be considered with caution since the ISE traces showed an initial efflux that was not maintained during the experiment time (see Figures S58-60 in the ESI).

Interestingly, we observed their ability to bind two chloride anions with very different binding constants for the corresponding $1: 1$ $\left(\sim 10^{4} \mathrm{M}^{-1}\right)$ and $1: 2$ complexes $\left(\sim 10^{2} \mathrm{M}^{-1}\right)$. This result is consistent with the encapsulation of an anion along with a weaker interaction with a second chloride. Likewise, similar chloride affinities $\left(\mathrm{BC}_{50^{\circ}}\right)^{[12]}$ were found, reflecting a conserved binding pocket for all the receptors.

The ionophoric activity of compounds 1a-e was first explored in model phospholipid bilayers by using POPC liposomes (Figure 2). ${ }^{[13,14]}$ First, the ability of these compounds to facilitate chloride efflux from chloride-loaded vesicles was monitored using a chloride selective electrode (ISE). ${ }^{[13 a]}$ The liposome suspension was placed in an isotonic, chloride-free medium and the studied cages were added as aliquots of stock solutions. Percent chloride efflux for each compound was monitored over time, since release of all encapsulated chloride by addition of a detergent allowed the normalization of the chloride leakage. Unspecific detergent effects induced by these compounds were ruled out with control experiments in vesicles loaded with carboxyfluorescein ${ }^{[13 d]}$ (Figure $\mathrm{S} 62$ in the ESI). Different internal and external $\mathrm{pH}$ conditions were tested (Figure $2 \mathrm{~A}$ and Table 1). The conditions for these experiments were chosen to be comparable to those expected under physiological conditions in terms of $\mathrm{pH}$ values and gradients. The cages showed moderate chloride transport abilities, being the efficiency dependent on the nature of the side chains. Thus, in general, the most efficient transporter was 1c, derived from 4-F-Phe, that is the most hydrophobic of the series. The specific behavior in the presence of a $\mathrm{pH}$ gradient is also very noticeable (Figure 2 and Table1). The use of acidic $\mathrm{pH}_{\mathrm{i}}$ and neutral $\mathrm{pH}_{\mathrm{e}}$ produced an increase of the chloride transport promoted by $\mathbf{1 c}(X=F)$, which was much lower with $\mathbf{1 b}(\mathrm{X}=\mathrm{OMe})$ and negligible for $1 \mathrm{a}(\mathrm{X}=\mathrm{H}$, compare orange and blue traces in Figure 2A). The use of both acidic $\mathrm{pH}_{\mathrm{i}}$ and $\mathrm{pH}_{\mathrm{e}}$ increased the chloride transport rates of the three cages, though to a different extent (red traces in Figure 2A). Thus, the fastest rate and highest effect of the acid medium was observed with the fluorinated cage 1c. This result was also confirmed by monitoring chloride influx using lucigenin fluorescent dye ${ }^{[13 c]}$ (Figure $S 61$ in the ESI). Additional experiments with vesicles loaded with a ratiometric fluorescent probe sensitive to $\mathrm{pH}$ (HPTS ${ }^{[14]}$ proved that these compounds efficiently dissipate $\mathrm{pH}$ gradients (Figure $2 \mathrm{~B}$ ). The relative efficiency was found well correlated to the relative activity as chloride transporters measured using ISE and lucigenin assays. Overall, the results suggest a $\mathrm{H}^{+} / \mathrm{Cl}^{-}$symport mechanism for the 1a-c cages that is facilitated by acidic media and strongly dependent on the nature of the host side chain.
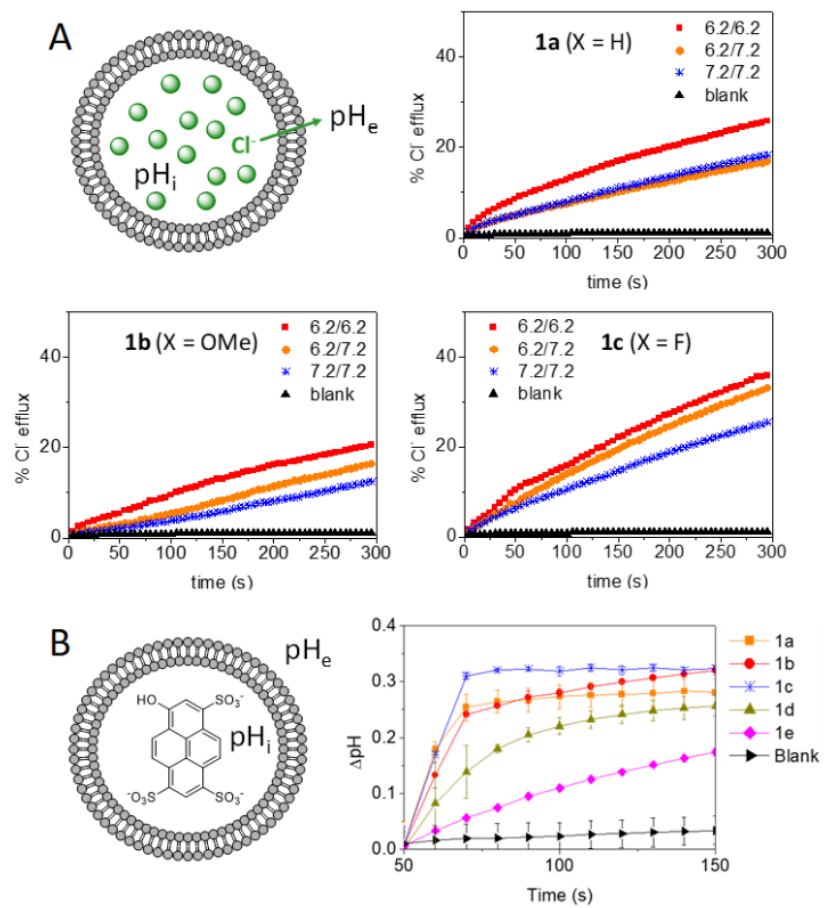

Figure 2. (A) ISE experiments to measure the chloride efflux promoted by 1a-c cages at different internal and external $\mathrm{pH}$. Each plot shows the average of three experiments. (B) HPTS assay showing the ability of 1a-c to dissipate $\mathrm{pH}$ gradients through lipid bilayers ( $10 \%$ cage to POPC molar ratio, ESI for details). 
In order to obtain a more precise picture of the process at the molecular level, we carried out NMR studies of $1 \mathrm{c}$ in an aqueouslipid phase. ${ }^{[15]}$ To that, deuterated-DPC micelles were suspended in $\mathrm{D}_{2} \mathrm{O}$ and a solution of $1 \mathrm{c}$ in DMSO- $d_{6}$ was added. Different conditions of the external aqueous phase were studied ranging from neutral to acidic $\mathrm{pH}$, and also in the absence and presence of salt (Figure 3). The DOSY NMR experiments performed in all the samples showed self-diffusion rates compatible with the total incorporation of the cage within the micelles (Table S8 in the ESI). Thus, $1 \mathrm{c}$ showed an apparent hydrodynamic radius $\left(r_{\mathrm{H}}\right)$ of $2.9 \mathrm{~nm}$, in a very good agreement with the reported size of DPC micelles ${ }^{[16]}$ and much larger than the $r_{\mathrm{H}}$ of the cage when DOSY experiments were performed with $1 \mathrm{c}$ in DMSO- $d_{6}(0.66 \mathrm{~nm}$ alone and $0.76 \mathrm{~nm}$ with protonated $1 \mathrm{c}$ and TBACl). The observed changes of the NMR spectra of 1c within the micelles upon variations in the composition of the external aqueous solution were also very illustrative. The proton NMR of the sample at $\mathrm{pH}$ 7.1 showed the presence of two set of signals for some of the protons, which were especially important for those of the aromatic side chains (Figure 3). Since there is always a low concentration of chloride in these samples ( 2-3 $\mathrm{mM}$ for $\mathrm{pH}$ adjustment), we assigned these signals to the free and chloride-bound cage complexes in slow exchange in the chemical shift NMR timescale. The addition of external $\mathrm{NaCl}$ induced minor changes (line broadening) in the NMR spectra, as expected by the weak chloride binding of the non-protonated cage. Interestingly, when the $\mathrm{pH}$ of the bulk aqueous solution was lowered, the addition of $\mathrm{NaCl}$ produced a dramatic increase of the signals for the chloridebound cage, demonstrating the ability of $1 \mathrm{c}$ to strongly bind $\mathrm{HCl}$ within the lipid phase.
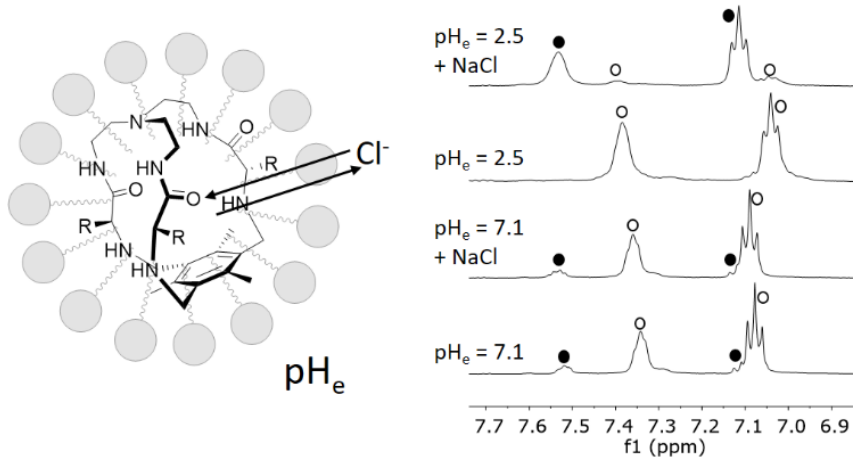

Figure 3. NMR experiments $(500 \mathrm{MHz}, 303 \mathrm{~K})$ performed with 1c $(0.4 \mathrm{mM})$ in deuterated DPC micelles (25 mM, one molecule of 1c per DPC micelle) suspended in $\mathrm{D}_{2} \mathrm{O}$ at different $\mathrm{pH}$ values and upon addition of $150 \mathrm{mM} \mathrm{NaCl}$. The aromatic region showed signals for the free $(\circ)$ and the chloride-bound $(\bullet)$ cage at slow exchange in the chemical shift NMR timescale.

Fortunately, the observation of split signals for the free and bound species allowed us to estimate the chloride exchange rate by EXSY experiments. ${ }^{[17]}$ The sample in acid medium showed a much faster chloride exchange $\left(k_{\mathrm{ex}}=2.7 \mathrm{~s}^{-1}\right.$ at $\left.303 \mathrm{~K}\right)$ than the one at neutral $\mathrm{pH}\left(k_{\mathrm{ex}}=0.2 \mathrm{~s}^{-1}\right.$ at $\left.303 \mathrm{~K}\right)$. The difference in the exchange rate was observed in several signals of the cages (Figures S77-S79 and S82 in the ESI). Accordingly, we concluded that the external aqueous acid medium produced a much stronger chloride binding and a much faster chloride exchange with a cage that remains in the lipid phase. To the best of our knowledge, this is the first direct experimental measurement of this type of processes occurring in an aqueous-lipid interface. Moreover, the fact that the aromatic signals of 1c were strongly affected by the process also suggested the active participation of the fluorinated side chain, most likely through $\mathrm{CH}$-anion or anion-m transient interactions. ${ }^{[18]}$

The biological activity of the cages in living cells was tested in a human lung adenocarcinoma cell line (A549) as a proof of concept. Thus, the cytotoxicity of all the studied cages was determined using the MTT assay ${ }^{[19]}$ (Figure 4 and Table 1). In order to test our hypothesis, we performed the experiments at different $\mathrm{pH}_{\mathrm{e}}$ values, namely using the standard conditions (DMEM medium, $\mathrm{pH}_{\mathrm{e}}$ 7.5) and with the presence of PIPES buffer to fix a slightly more acidic external medium $\left(\mathrm{pH}_{\mathrm{e}} 7.2\right.$ and 6.2). ${ }^{[5 b]}$ Compounds 1a-c displayed cytotoxic activities with interesting $\mathrm{pH}$ dependence, whereas 1d,e were found essentially nontoxic. The Phe derivative rendered $\mathrm{IC}_{50}$ values unaffected by $\mathrm{pH}_{\mathrm{e}}$, while the O-Me-Tyr counterpart showed a slightly higher activity as the $\mathrm{pH}_{\mathrm{e}}$ was lower. The performance of $\mathbf{1 c}$ bearing the 4-F-Phe derivative was especially interesting, since this receptor systematically increased the cytotoxicity as the $\mathrm{pH}_{\mathrm{e}}$ was decreased (Figure 4 and Table 1). Most remarkably, 1c showed to be five-fold more cytotoxic at acidic $\mathrm{pH}_{\mathrm{e}}$ than under the conventional conditions. This allows a relatively wide concentration window $(50-150 \mu \mathrm{M})$ for which 1c would be safe for cells surrounded by weakly basic $\mathrm{pH}$ (healthy cells conditions), but cytotoxic for cells in an acidic microenvironment (such as for solid tumors). The trends observed for the biological activity at different $\mathrm{pH}_{\mathrm{e}}$ values correlated well with the trends observed for the transport assays in model liposomes. Moreover, the MTT assays with 1c at reduced concentration of chloride also showed a decreased cytotoxicity (Figure $\mathrm{S} 83$ in the ESI). Overall, these results are in good agreement with a key role of the ionophoric activity of compounds 1a-c in the observed biological activity.
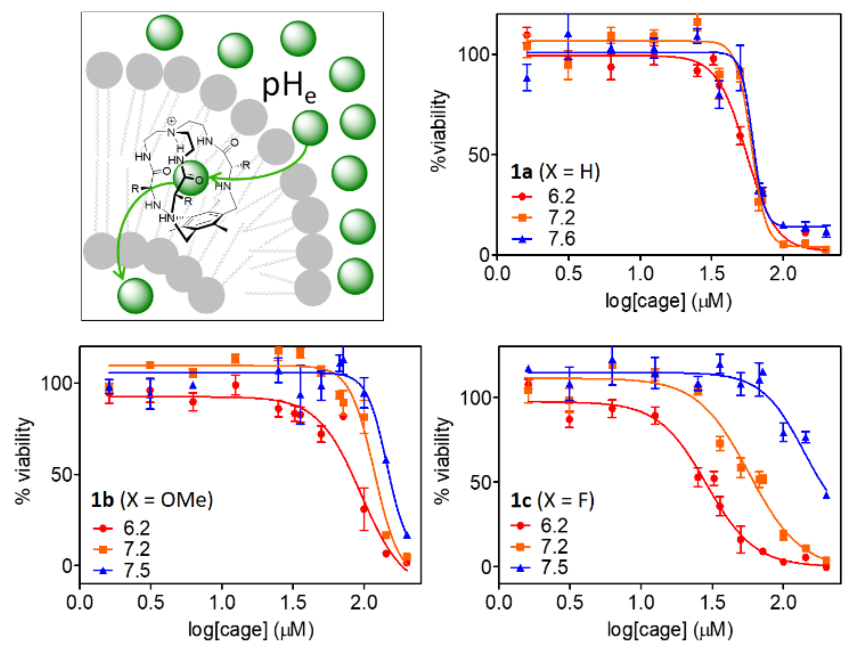

Figure 4. Schematic representation of the cytotoxicity experiments (A549 cell line) and plots of the percent cell viability versus the concentration of the cages 1a-c, performed at different $\mathrm{pH}_{\mathrm{e}}$ values (referenced to their corresponding blanks, see ESI). The results correspond to the average of two independent experiments performed in triplicates each (error bars show standard deviation).

In conclusion, we have developed small pseudopeptidic cages able to exchange $\mathrm{HCl}$ through aqueous-lipid interfaces. The specific behavior of these transporters depend on the nature of the amino acid side chains. Thus, a fluorinated Phe derivative showed an increased $\mathrm{HCl}$ transport ability and a higher cytotoxicity to cancer cells in the presence of $\mathrm{pH}$ gradients 
resembling those characteristic of tumor microenvironments. Our results open the way to further design new $\mathrm{pH}$-dependent anionophores for applications in cancer chemotherapy, with the aim to improve their selectivity for the target.

\section{Acknowledgements}

Financial Support from the Ministry of Science, Innovation and Universities (RTI2018-096182-B-I00, MCIU/AEI/FEDER, EU), AGAUR (2017 SGR 208), Consejería de Educación de la Junta de Castilla y León (BU092U16) and personal support for L. Tapia (BES-2016-076863) are gratefully acknowledged. The $500 \mathrm{MHz}$ spectrometer was funded by MINECO-FEDER (CSIC13-4E2076).

Keywords: supramolecular chemistry $\bullet$ cages $•$ anionophores $•$ cancer $\cdot$ NMR

[1] J. R. Casey, S. Grinstein, J. Orlowski, Nat. Rev. Mol. Cell Biol. 2010, 11, $50-61$.

[2] B. A. Webb, M. Chimenti, M. P. Jacobson, D. L. Barber, Nat. Rev. Cancer 2011, 11, 671-677.

[3] a) D. Lagadic-Gossmann, L. Huc, V. Lecureur, Cell Death Differ. 2004, 11, 953-961; b) S. Matsuyama, J. Llopis, Q. L. Deveraux, R. Y. Tsien, J. C. Reed, Nat. Cell Biol. 2000, 2, 318-325.

[4] a) C. Stock, A. Schwab, Pflugers Arch.-Eur. J. Physiol. 2009, 458, $981-$ 992; b) R. A. Gatenby, E. T. Gawlinski, A. F. Gmitro, B. Kaylor, R. J. Gillies, Cancer Res. 2006; 66, 5216-5223.

[5] a) T. Fukamachi, X. Wang, Y. Mochizuki, C. Maruyama, H. Saito, H. Kobayashi, Int. Immunopharmacol. 2013, 17, 148-153. b) T. Fukamayachi, Y. Chiba, X. Wang, H. Saito, M. Tagawa, H. Kobayashi, Cancer Lett. 2010, 297, 182-189; c) L. E. Gerweck, S. Vijayappa, S. Kozin, Mol. Cancer Ther. 2006, 5, 1275-1279.

[6] a) E. Hernando, V. Capurro, C. Cossu, M. Fiore, M. García-Valverde, V. Soto-Cerrato, R. Pérez-Tomás, O. Moran, O. Zegarra-Moran, R. Quesada, Sci. Rep. 2018, 8, 2608; b) N. Busschaert, S.-H. Park, K.-H. Baek, Y. P. Choi, J. Park, E. N. W. Howe, J. R. Hiscock, L. E. Karagiannidis, I. Marques, V. Félix, W. Namkung, J. L. Sessler, P. A. Gale, I. Shin, Nat. Chem. 2017, 9, 667-675; c) V. Soto-Cerrato, P. Manuel-Manresa, E. Hernando, S. Calabuig-Fariñas, A. MartínezRomero, V. Fernández-Dueñas, K. Sahlholm, T. Knöpfel, M. GarcíaValverde, A. M. Rodilla, E. Jantus-Lewintre, R. Farràs, F. Ciruela, R. Pérez-Tomás, R. Quesada, J. Am. Chem. Soc. 2015, 137, 15892-15898; d) S.-K. Ko, S. K. Kim, A. Share, V. M. Lynch, J. Park, W. Namkung, W. Van Rossom, N. Busschaert, P. A. Gale, J. L. Sessler, I. Shin, Nat. Chem. 2014, 6, 885-892; e) P. A. Gale, R. Pérez-Tomás, R. Quesada, Acc. Chem. Res. 2013, 46, 2801-2813; f) I. Alfonso, R. Quesada, Chem. Sci. 2013, 4, 3009-3019.

[7] a) P. A. Gale, J. T. Davis, R. Quesada, Chem. Soc. Rev. 2017, 46, 24972519; b) X. Wu, L. W. Judd, E. N. W. Howe, A. M. Whitecombe, V. SotoCerrato, H. Li, N. Busschaert, H. Valkenier, R. Pérez-Tomás, D. N. Sheppard, Y.-B. Jiang, A. P. Davis, P. A. Gale, Chem 2016, 1, 127-146. c) E. Hernando, V. Soto-Cerrato, S. Cortés-Arroyo, R. Pérez-Tomás, R Quesada, Org. Biomol. Chem. 2014, 12, 1771-1778; d) P. A. Gale, N. Busschaert, Angew. Chem. Int. Ed. 2013, 52, 1374-1382; Angew. Chem. 2013, 125, 1414-1422; e) S. J. Moore, C. J. E. Haynes, J. González, J. L. Sutton, S. J. Brooks, M. E. Light, J. Herniman, G. J. Langley, V. SotoCerrato, R. Pérez-Tomás, I. Marques, P. J. Costa, V. Félix, P. A. Gale, Chem. Sci., 2013, 4, 103-117; f) B. Díaz de Greñu, P. Iglesias Hernández, M. Espona, D. Quiñonero, M. E. Light, T. Torroba, Ricardo Pérez-Tomás, R. Quesada, Chem. Eur. J. 2011, 17, 14074-14083.

[8] a) L. A. Jowett, E. N. W. Howe, V. Soto-Cerrato, W. Van Rossom, R. Pérez-Tomás, P. A. Gale, Sci. Rep. 2017, 7, 9397; b) H. Li, H. Valkenier, L. W. Judd, P. R. Brotherhood, S. Hussain, J. A. Cooper, O. Jurček, H. A. Sparkes, D. N. Sheppard, A. P. Davis, Nat. Chem. 2016, 8, 24-32.
[9] a) S. V. Shinde, P. Talukdar, Angew. Chem. Int. Ed. 2017, 56, 42384242; Angew. Chem. 2017, 129, 4302-4306; b) A. Roy, O. Biswas, P. Talukdar, Chem. Commun. 2017, 53, 3122-3125; c) E. N. W. Howe, N. Busschaert, X.Wu, S. N. Berry, J. Ho, M. E. Light, D. D. Czech, H. A. Klein, J. A. Kitchen, P. A. Gale, J. Am. Chem. Soc. 2016, 138, 83018308; d) R. B. P. Elmes, N. Busschaert, D. D. Czech, P. A. Gale, K. A. Jolliffe, Chem. Commun. 2015, 51, 10107-10110; e) N. Busschaert, R. B. P. Elmes, D. D. Czech, X. Wu, I. L. Kirby, E. M. Peck, K. D. Hendzel, S. K. Shaw, B. Chan, B. D. Smith, K. A. Jolliffe, P. A. Gale, Chem. Sci. 2014, 5, 3617-3626.

[10] I. Martí, M. Bolte, M. I. Burguete, C. Vicent, I. Alfonso, S. V. Luis, Chem Eur. J. 2014, 20, 7458-7464.

[11] I. Martí, J. Rubio, M. Bolte, M. I. Burguete, C. Vicent, R. Quesada, I. Alfonso, S. V. Luis, Chem. Eur. J. 2012, 18, 16728-16741.

[12] A. Vacca, O. Francesconi, S. Roelens, Chem. Rec. 2012, 12, 544-566.

[13] a) L. A. Jowett, P. A. Gale, Supramol. Chem. 2019, 31, 297-312; b) X. Wu, E. N. W. Howe, P. A. Gale, Acc. Chem. Res. 2018, 51, 1870-1879 c) B.A. McNally, A.V. Koulov, B.D. Smith, J.-B. Joos, A. P. Davis, Chem. Commun. 2005, 1087-1089; d) P. H. Schlesinger, N. K. Djedovič, R. Ferdani, J. Pajewska, R. Pajewski, G. W. Gokel, Chem. Commun. 2003, 308-309.

[14] a) P. Xin, H. Kong, Y. Sun, L. Zhao, H. Fang, H. Zhu, T. Jiang, J. Guo, Q. Zhang, W. Dong, C.-P. Chen, Angew. Chem. Int. Ed. 2019, 58, 27792784; Angew. Chem. 2019, 131, 2805-2810; b) Y. J. Jeon, H. Kim, S. Jon, N. Selvapalam, D. H. Oh, I. Seo, C.-S. Park, S. R. Jung, D.-S. Koh, K. Kim, J. Am. Chem. Soc. 2004, 126, 15944-15945.

[15] a) E. Brunetti, A. Inthasot, F. Keymeulen, O. Reinaud, I. Jabin, K. Bartik, Org. Biomol. Chem. 2015, 13, 2931-2938; b) D. A. Kallick, M. R. Tessmer, C. R. Watts, C. Y. Li. J. Magn. Reson. B 1995, 109, 60-65.

[16] E. Pambou, J. Crewe, M. Yaseen, F. N. Padia, S. Rogers, D. Wang, H. Xu, J. R. Lu, Langmuir 2015, 31, 9781-9789.

[17] C. L. Perrin, T. J. Dwyer, Chem. Rev. 1990, 90, 935-967.

[18] A. V. Jentzsch, D. Emery, J. Mareda, P. Metrangolo, G. Resnati, S. Matile, Angew. Chem. Int. Ed. 2011, 50, 11675-11678; Angew. Chem. 2011, 123, 11879-11882.

[19] J. C. Stockert, R. W. Horobin, L. L. Colombo, A. Blázquez-Castro, Acta Histochem. 2018, 120, 159-167. 
Entry for the Table of Contents (Please choose one layout)

Layout 1:

\section{COMMUNICATION}

Tailored small pseudopeptidic cages improve their chloride binding and transport properties at slightly acidic $\mathrm{pH}$ values. This induces enhanced cytotoxic activity towards lung adenocarcinoma cells in environments mimicking those surrounding solid tumors.

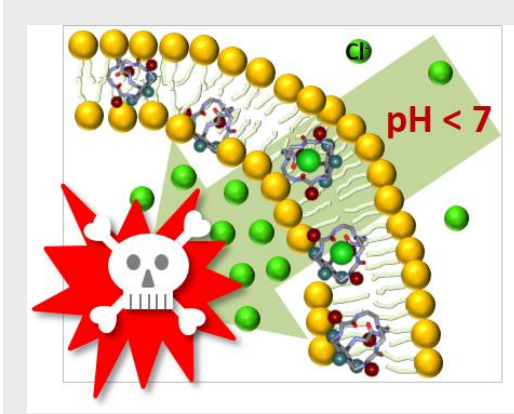

Lucía Tapia, Yolanda Pérez, Michael Bolte, Josefina Casas, Jordi Solà, Roberto Quesada, Ignacio Alfonso*

Page No. - Page No.

pH-dependent chloride transport by pseudopeptidic cages for the selective killing of cancer cells in acidic microenvironments 


\title{
pH-dependent chloride transport by pseudopeptidic cages for the selective killing of cancer cells in acidic microenvironments
}

\author{
Lucía Tapia, ${ }^{[a]}$ Yolanda Pérez, ${ }^{[b]}$ Michael Bolte, ${ }^{[c]}$ Josefina Casas, ${ }^{[a]}$ Jordi Solà, ${ }^{[a]}$ Roberto Quesada ${ }^{[d]}$ \\ and Ignacio Alfonso* [a]
}

\begin{abstract}
Acidic microenvironments in solid tumors is a hallmark of cancer. Inspired by that, we designed a family of pseudopeptidic cage-like anionophores displaying $\mathrm{pH}$-dependent activity. When protonated, they efficiently bind chloride anion as shown by NMR titration in aqueous acetonitrile. They also transport chloride through lipid bilayers (ISE experiments in POPC liposomes), being the anionophoric properties improved at acidic $\mathrm{pH}$, which suggests an $\mathrm{H}^{+} / \mathrm{Cl}^{-}$symport mechanism. NMR studies in DPC micelles demonstrate the ability of the cages to bind chloride within the lipid phase. Moreover, the corresponding affinity and the chloride exchange rate with the aqueous bulk solution are improved when the $\mathrm{pH}$ is lowered. These results offer insights into the process at the molecular level. This behavior induces an increased cytotoxicity towards lung adenocarcinoma cells in the $\mathrm{pH}$ conditions mimicking those of the solid tumors. Besides, all these properties are finely tuned by the nature of the side chains of the cages, namely the external decoration of the molecules that modulates their lipophilicity and potential interactions with the cell membrane. Our study paves the way towards using $\mathrm{pH}$ as a parameter to control the selectivity of cytotoxic ionophores as anti-cancer drugs.
\end{abstract}

DOI:

\section{Table of Contents}

Material and methods

General

NMR spectroscopy

ESI mass spectrometry

NMR spectroscopy in micelles

Fluorescence

Chloride Selective Electrode measurements

$\mathrm{pH}$ measurements

Results and discussion

Synthetic methodology

$X$ Ray crystal analysis

Crystal structure determinations

Titration with TBACl: binding constants

Log $P$ calculation and retention time determination 


\section{Experimental Procedures}

\section{Material and Methods}

\section{General}

Reagents and solvents were purchased from commercial suppliers (Adrich, Fluka or Merck) and were used without further purification. Compound 1a was synthetized as previously described ${ }^{1}$. All the compounds prepared were fully characterized by the complete spectroscopic (NMR, ESI-MS) and analytical data. Preparative reverse phase purifications were performed on an Isolera Biotage instrument (KP-C18-HS, $\mathrm{CH}_{3} \mathrm{CN}$ and water with $0.1 \%$ TFA). Analytical RP-HPLC was performed with a Hewlett Packard Series 1100 (UV detector 1315A) modular system using a reverse-phase Kromasil $100 \mathrm{C} 8(15 \times 0.46 \mathrm{~cm}, 5 \mu \mathrm{m})$ column. $\mathrm{CH}_{3} \mathrm{CN}-\mathrm{H}_{2} \mathrm{O}$ mixtures containing $0.1 \%$ TFA at $1 \mathrm{~mL} / \mathrm{min}$ were used as mobile phase and monitoring wavelengths were set at 220,254 and $280 \mathrm{~nm}$.

\section{NMR spectroscopy}

The NMR experiments were carried out at $25^{\circ} \mathrm{C}$ on a VNMRS-400 NMR spectrometer (Agilent Technologies $400 \mathrm{MHz}$ for ${ }^{1} \mathrm{H}$ and 100 $\mathrm{MHz}$ for ${ }^{13} \mathrm{C}$ ) for characterization and a Bruker Avance-III $500 \mathrm{MHz}$ spectrometer equipped with a z-axis pulsed field gradient triple resonance $\left({ }^{1} \mathrm{H},{ }^{13} \mathrm{C},{ }^{15} \mathrm{~N}\right) \mathrm{TCl}$ cryoprobe $\left(500 \mathrm{MHz}\right.$ for ${ }^{1} \mathrm{H}$ and $125 \mathrm{MHz}$ for $\left.{ }^{13} \mathrm{C}\right)$. Chemical shifts are reported in ppm using tetrakistrimethylsilylsilane as a reference. Data were processed with the software program MNova (Mestrelab Research).

\section{ESI mass spectrometry}

High resolution mass spectra (HRMS) were performed on Acquity UPLC System and a LCT PremierTM XE Benchtop orthogonal acceleration time-of-flight (oa-TOF) (Waters Corporation, Milford, MA) equipped with an electrospray ionization source. All sample solution (in the $1 \times 10^{-4}$ to $1 \times 10^{-6} \mathrm{M}$ range) were prepared in methanol.

\section{NMR spectroscopy in micelles.}

All data were acquired using a Bruker Avance-III $500 \mathrm{MHz}$ spectrometer equipped with a z-axis pulsed field gradient triple resonance $\left({ }^{1} \mathrm{H},{ }^{13} \mathrm{C},{ }^{15} \mathrm{~N}\right) \mathrm{TCl}$ cryoprobe. For all NMR experiments with cages in presence of DPC-d38 (dodecylphosphocholine) micelles, we worked at $25 \mathrm{mM}$ monomer concentration, well above cmc (1.36 mM in PBS). ${ }^{2}$ For the incorporation of pseudopeptidic cages into DPC micelles, a homogeneous solution of detergent in $\mathrm{D}_{2} \mathrm{O}$ was prepared and the cage was added from a weighted stock solution prepared in DMSO-d6. After vigorous vortexing to assure the incorporation of the cage to the micelles (also checked by diffusion coefficient measurements, see below), the $\mathrm{pH}$ was adjusted. Due to the limited solubility of pseudopeptidic host in aqueous solution, the samples in $\mathrm{DPC} / \mathrm{D}_{2} \mathrm{O}$ solution have a final concentration of $0.4 \mathrm{mM}$ cage with a $\sim 1: 1$ cage:DPC micelles ratio (using known aggregation number $\sim 55-60) .{ }^{3}$ The samples at these concentrations were stable and optically clear (without observable precipitation or phase separation) over all the NMR experiments. Regarding the pH adjustment, preliminary studies showed that using a buffer (in $\mathrm{D}_{2} \mathrm{O}$ ) could interfere with anion recognition. ${ }^{4}$ In our case, even using Tris $\cdot \mathrm{HCl}$ in low concentration $(20 \mathrm{mM}$, cited at the literature as one of the buffers with the least competitive chloride counteranion), interfered with chloride binding and caused sample precipitation. Thus, all the cage/DPC samples were prepared in $\mathrm{D}_{2} \mathrm{O}$ without any buffer and the $\mathrm{pH}$ (acidic or neutral) was adjusted using the minimum amount of $\mathrm{DCl} / \mathrm{NaOD}$ (from a $0.2 \mathrm{M}$ stock in $\mathrm{D}_{2} \mathrm{O}$ ), so at the end of the $\mathrm{pH}$ adjustment the added chloride concentration was always lower than 6-7 mM.

Two-dimensional (2D) spectra (NOESY, ROESY, COSY and HSQC) were acquired at $303 \mathrm{~K}$. For samples in DPC-d38/ $\mathrm{D}_{2} \mathrm{O}$, the water resonance was suppressed by "3-9-19" pulse sequence with gradients using flip-back pulse in NOESY experiments (pulse sequence noesyfpgpphwg), 3-9-19 suppression sequence in ROESY experiments (pulse sequence roesygpph19) and presaturation for COSY experiments (pulse sequence cosygpprqf). ${ }^{1} \mathrm{H}-{ }^{1} \mathrm{H}$ NOESY spectra were acquired with a mixing time of $150 \mathrm{~ms}$ (in DPC) and $250 \mathrm{~ms}$ (in DMSO-d6) and ${ }^{1} \mathrm{H}-{ }^{1} \mathrm{H}$ ROESY spectra with a mixing time between 2-75 ms. The comparison of NOESY and ROESY spectra allowed to detect those cross peaks in NOESY spectra originated by spin-diffusion and to identify exchange peaks. $2 \mathrm{D}{ }^{1} \mathrm{H}-{ }^{13} \mathrm{C} H S Q \mathrm{H}$ experiments were acquired with Bruker pulse sequence hsqcdietgpsisp. 2D experiments were processed with the standard TOPSPIN program (Bruker Biospin, Karlsruhe, Germany). The 2D data matrices were multiplied by square-sine bell window function with the corresponding shift optimized for every spectrum and zero-filled to $2 \times 1 \mathrm{~K}$ complex matrices prior to Fourier transformation. Baseline correction was applied in both dimensions.

Exchange constants were calculated using the software EXSYCALC 1.0 (MestreLab Research). In brief, for the calculation of rate exchange constants, the program requires the experimental intensities of NMR peaks obtained from two EXSY experiments: one at a certain mixing time large enough for the magnetization exchange to take place (tm), and another acquired at a mixing time short enough not to see exchange peaks (reference). In the first experiment the volume integrals of those signals in exchange, A(tm), are quantified for both diagonal and cross peaks. In the EXSY reference experiment, since no exchange peaks are observed, the amplitudes of just the diagonal peaks, $\mathrm{A}(0)$, are measured. The values of these integrals are introduced in EXSYCALC 1.0 and the program directly computes the corresponding exchange rate constants, by solving the full relaxation matrix of the system. ${ }^{5}$

\footnotetext{
${ }^{1}$ I. Marti;J. Rubio, M. Bolte, M. I. Burguete, C. Vicent, I. Alfonso, S. V. Luis, Chem. Eur. J. 2014, 20, 7458-7464.

${ }^{2}$ E. Sikorska, D. Wyrzykowski, K. Szutkowski, K. Greber, E. A. Lubecka, I. J. Therm. Anal. Calorim 2015, 123, 511-523.

${ }^{3}$ D.A. Kallick, M.R. Tessmer, C.R. Watts, Y. LiC, J. Magn. Reson. 1995, 109, 60-65.

${ }^{4}$ Q. Yu, A. Kandegedara, Y. Xu, D. B. Rorabacher, Anal. Biochem. 1997, 253, 50-56.

5 J. Lu, D. Ma, J. Hu, W. Tang, D. Zhu, J. Chem. Soc. Dalton Trans. 1998, 2267-2273.
} 
For PFG-NMR diffusion experiments, the field gradient strength $(\mathrm{Gz})$ was calibrated by measuring the self-diffusion coefficient of residual $\mathrm{H}_{2} \mathrm{O}$ in a $100 \%{ }^{2} \mathrm{H}_{2} \mathrm{O}$ sample at $298.0 \mathrm{~K}$. A diffusion coefficient of $1.91 \times 10^{-9} \mathrm{~m}^{2} \mathrm{~s}^{-1}$ for the residual $\mathrm{H}_{2} \mathrm{O}$ signal was then used for the back calculation of the field gradient strength. ${ }^{6}$ For $\mathrm{D}_{2} \mathrm{O}$ samples, diffusion NMR experiments were acquired at $303 \mathrm{~K}$ using Shigemi tubes to minimize convection effects. ${ }^{7}$ The stebpgp1s 19 pulse sequence with WATERGATE 3-91-9 for water suppression and one spoil gradient was used. The diffusion coefficient, D, was determined by fitting diffusion weighted intensities of selected peaks or integrals over a chosen range to the following equation:

$\mathrm{I}=\mathrm{I}_{0} \exp \left\{-\mathrm{Y}^{2} \mathrm{~g}^{2} \delta^{2}(\Delta-\delta / 3) D\right\}($ Eq. 1$)$

Where $\mathrm{y}$ is the gyromagnetic ratio of proton and $\mathrm{g}, \delta$ and $\Delta$ are the amplitude, duration and separation of the single pair of gradient pulses, respectively. Due to the use of bipolar gradient elements, $\Delta$ is replaced by $\left(\Delta-T_{1} / 2\right)$ in Eq. (1), with $T_{1}$ being the time interval between the bipolar gradient pulses within the bipolar gradient encoding or decoding segment. Fittings to Eq. (1) were performed using Bruker Dynamics Center.

The pulsed-field-gradient signal attenuation was monoexponential for all resonances. In the case of DPC, this indicated that the exchange of lipid molecules between micelles and free solution is fast in the NMR time scale. Under these conditions, the observed diffusion coefficient is the weighted average of the free $\left(D_{\text {free }}\right)$ and micellar $\left(D_{\text {mic }}\right)$ values:

$D_{\text {obs }}=f_{\text {free }} D_{\text {free }}+f_{\text {mic }} D_{\text {mic }}($ Eq. 2$)$

In which $f_{\text {free }}$ and $f_{\text {mic }}$ are the mole fraction of free and micellar DPC. The measured self-diffusion coefficients values obtained for the pseudopeptidic cage in different media conditions (DMSO-d6, micelles/ $\mathrm{D}_{2} \mathrm{O}$ at different $\mathrm{pH}$ and with/without $150 \mathrm{mM} \mathrm{NaCl}$ ) and dodecylphosphocholine protons (residual non-deuterated protons) are shown in Table S1. The self-coefficient diffusion for DPC protons $\left(\left(\mathrm{CH}_{2}\right)_{\mathrm{n}}\right.$ and $\left.\mathrm{CH}_{3}\right)$ are in the range $10-12 \times 10^{-11} \mathrm{~m}^{2} / \mathrm{s}$ (at $303 \mathrm{~K}$ in $\left.\mathrm{D}_{2} \mathrm{O}\right)$, similar to known values from DPC micelles in literature, ${ }^{8,9}$ a confirmation that in our experimental conditions we have micellar aggregates. The reason for DPC self-diffusion coefficients being higher than the values from absorbed cage is the presence of free monomeric DPC molecules (with concentration smaller than $\mathrm{cmc}$ ) in fast exchange with micelles in solution. However, the observed cage resonances and their self-diffusion coefficients, smaller than DPC diffusion coefficients, mainly correspond to DPC-bound molecules and act as a probe for the cage incorporation to the micelles, so $D_{\text {mic }}(D P C) \sim D_{\text {cage }}$ (micelle-bound cages).

\section{Fluorescence}

Fluorescence emission was recorded using a HITACHI F-7000 Fluorescence spectrophotometer equipped with stirrer. Two different types of cuvettes were used depending on the assay: standard $10 \mathrm{~mm}$ quartz glass cells from Hellma Analytics High Precision Cell made of Quartz SUPRASIL or disposables MAPM-F10-100 labbox cuvettes. All measurements were performed at $25{ }^{\circ} \mathrm{C}$ unless specified.

\section{Chloride Selective Electrode measurements}

Chloride concentration in transport experiments was recorded using a Combination Chloride Electrode HI4107 Hanna Instruments and a Chloride Selective Electrode 9652 C Crison.

pH measurements were made using a CRISON pHmeter $5014 \mathrm{~T}$.

\footnotetext{
${ }^{6}$ L. G. Longsworth, J Phys Chem 1960, 64, 1914-1917.

${ }^{7}$ K. C. Chung, H-Y. Yu, S.D. Ahn, Bulletin of the Korean Chemical Society 2011, 32, 1970-1974.

8 J. Lauterwein, C. Bosch, L. R. Brown, K. Wuthrich, Biochim. Biophys. Acta 1979, 556, 244-264.

${ }^{9}$ C. Gobl, M. Dulle, W. Hohlweg, J. Grossauer, S. F. Falsone, O. Glatter, K. Zangger, J. Phys. Chem. A. 2010, 114, 4717-4724.
} 


\section{Results and Discussion}

\section{Synthetic methodology}

\section{Synthesis of $1 \mathrm{~b}$}

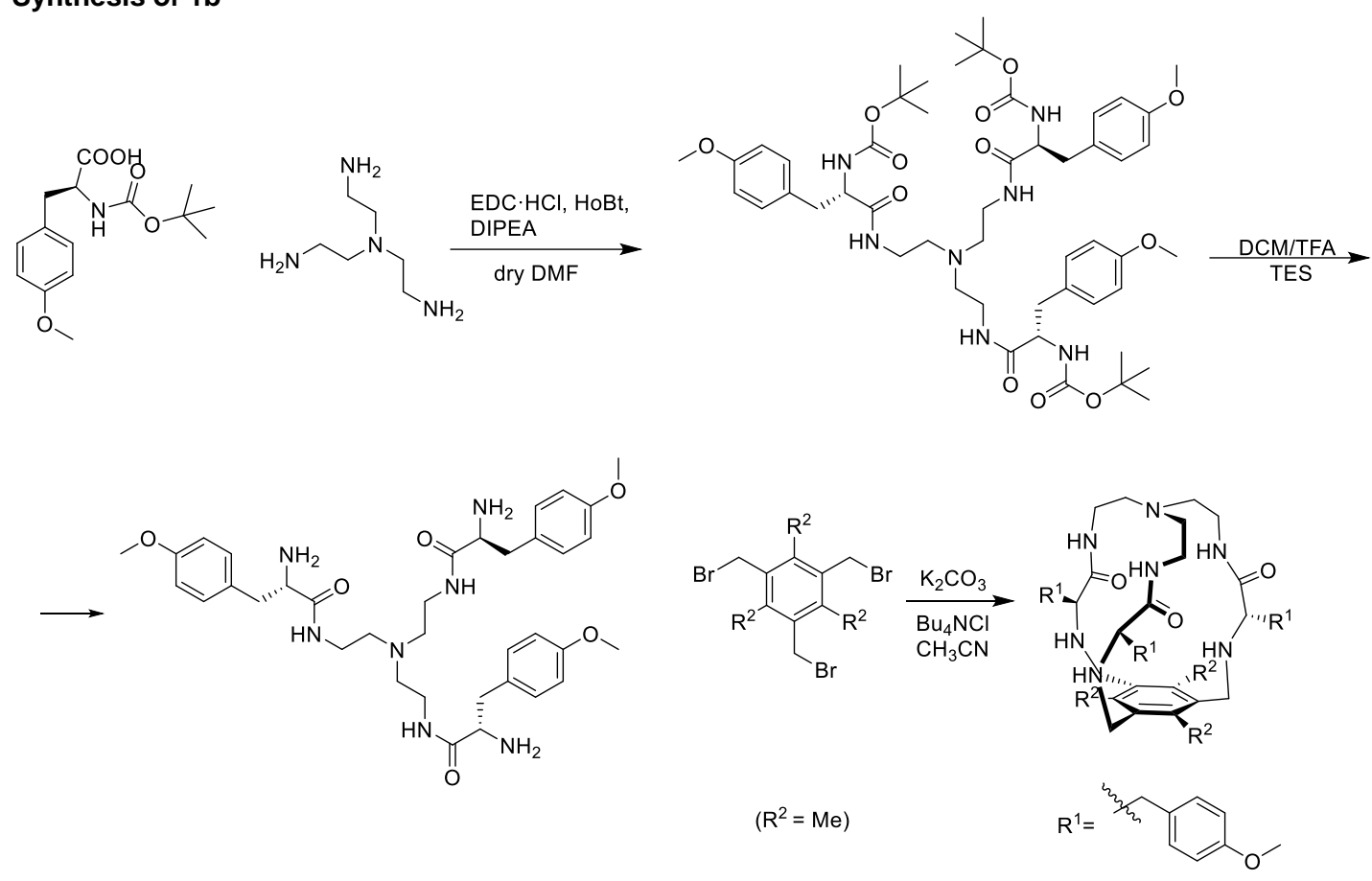

Scheme S1. Full synthetic scheme of $1 \mathrm{~b}$

2b tri-tert-butyl((2S,2'S,2"S)-((nitrilotris(ethane-2,1-diyl))tris(azanediyl))tris(3-(4-methoxy phenyl)-1-oxopropane-1,2diyl))tricarbamate<smiles>COc1ccc(C[C@H](NC(=O)OC(C)(C)C)C(=O)NCCN(CCNC(=O)[C@H](Cc2ccc(OC)cc2)NC(=O)OC(C)(C)C)CCNC(=O)[C@H](Cc2ccc(OC)cc2)NC(=O)OC(C)(C)C)cc1</smiles>

Figure $\mathbf{S 1}$. Structure of $\mathbf{2 b}$

Boc-Tyr(Me)-OH (375 mg, $1.27 \mathrm{mmol})$ was dissolved in dry DMF (2.5 mL). N-(3 Dimethylaminopropyl)-N'-ethylcarbodiimide hydrochloride (EDC. $\mathrm{HCl} 0.394 \mathrm{mg}, 1.53 \mathrm{mmol}$ ), 1-Hydroxybenzotriazole hydrate (HOBt, $0.207 \mathrm{mg}, 1.53 \mathrm{mmol}$ ), N,NDiisopropylethylamine (DIPEA, $0.8 \mathrm{~mL}, 4.6 \mathrm{mmol})$ and tris(2-aminoethyl)amine $(0.06 \mathrm{~mL}, 0.38 \mathrm{mmol})$ were added over the solution. The solution was stirred at room temperature for 16 hours, when no more conversion of the starting material was observed by TLC. The mixture was diluted with water and extracted with DCM $(3 \times 10 \mathrm{~mL})$. Combined organic fractions were washed with aqueous $\mathrm{LiCl}$ $(5 \% \mathrm{w} / \mathrm{w})$, dried over $\mathrm{MgSO}_{4}$ and concentrated to dryness. The residue was purified by flash chromatography using DCM:MeOH 95:5 to give $0.298 \mathrm{mg}$ of $2 \mathrm{~b}(0.307 \mathrm{mmol}, 80 \%$ yield $)$.

${ }^{1} \mathrm{H}$ NMR $\left(400 \mathrm{MHz}, \mathrm{CD}_{3} \mathrm{Cl}\right): \delta(\mathrm{ppm})=7.69(\mathrm{~s}, 3 \mathrm{H}), 7.15$ (A subsystem from $\left.\mathrm{AB}, J_{A B}=8.3 \mathrm{~Hz}, 6 \mathrm{H}\right), 6.76$ (B subsystem from $\mathrm{AB}, J_{A B}=8.4$ $\mathrm{Hz}, 6 \mathrm{H}$ ), 5.65 (d, J=8.8 Hz, 3H), 4.67 (X subsystem from ABX, $\left.J_{A X}=6.3, J_{B X}=8.6 \mathrm{~Hz}, 3 \mathrm{H}\right) 3.77(\mathrm{~s}, 9 \mathrm{H}), 3.35$ (m, $\left.3 \mathrm{H}\right), 3.01(\mathrm{~A}$ subsystem from $\left.A B X, J_{A B}=13.8, J_{A X}=6.3 \mathrm{~Hz}, 3 \mathrm{H}\right), 2.86\left(\mathrm{dd}, \mathrm{B}\right.$ subsystem from $\left.\mathrm{ABX}, J_{A B}=13.8, J_{B X}=8.6 \mathrm{~Hz}, 3 \mathrm{H}\right) 2.84(\mathrm{~m}, 3 \mathrm{H}), 2.48(\mathrm{~m}, 3 \mathrm{H}), 2.39(\mathrm{~m}$, $3 \mathrm{H}), 1.32(\mathrm{~s}, 27 \mathrm{H})$. 
${ }^{13} \mathrm{C} \mathrm{NMR}\left(101 \mathrm{MHz}, \mathrm{CDCl}_{3}\right): \delta(\mathrm{ppm})=189.3,181.1,172.9,158.2,158.2,130.3,113.6,55.6,55.1,54.9,38.7,38.3,28.3$. (Data obtained from HSQC and HMBC spectra)

HRMS (ESI-TOF) m/z [2b + H]+ Calc.: 978.5546, found: 978.6500.

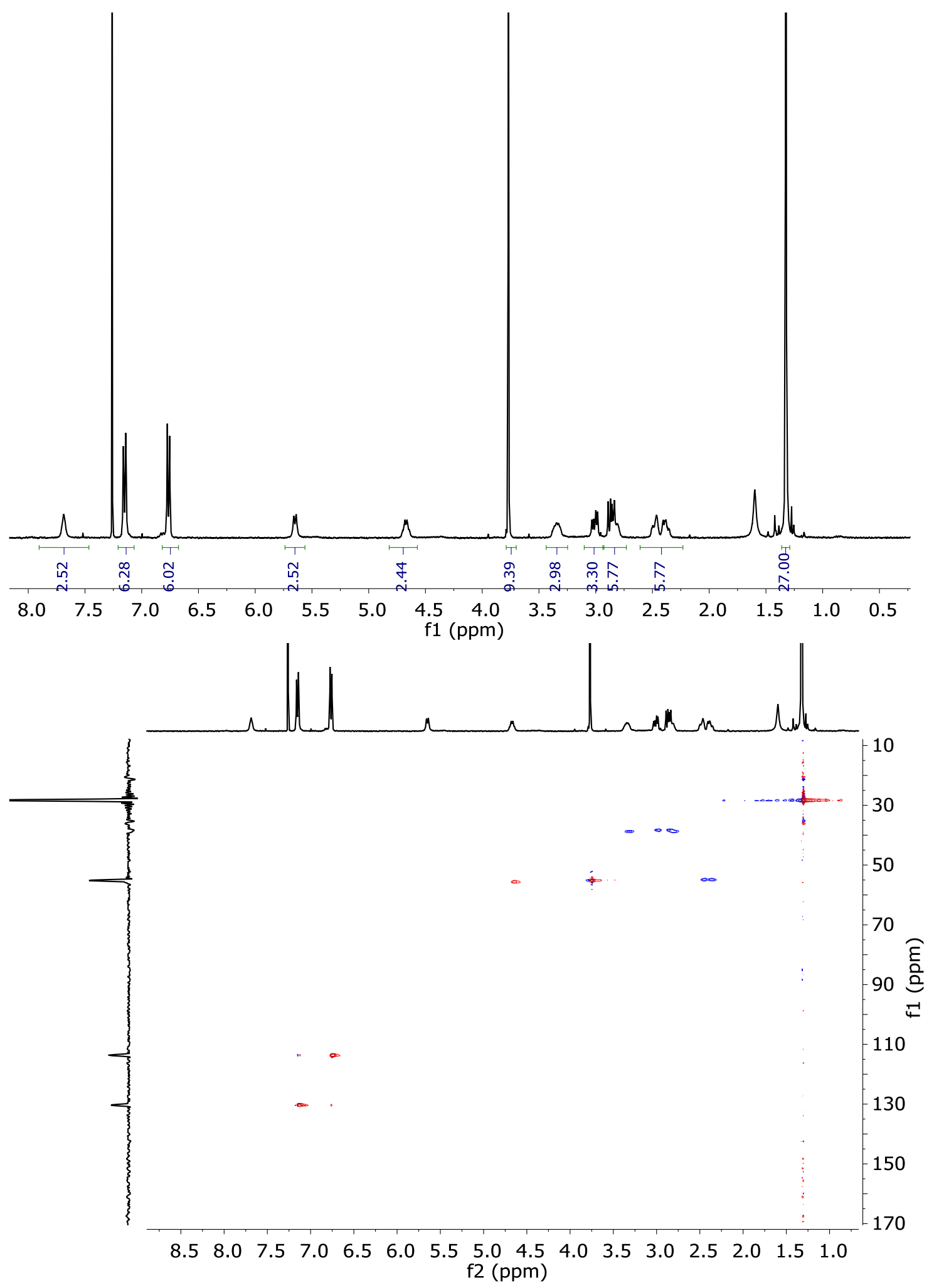




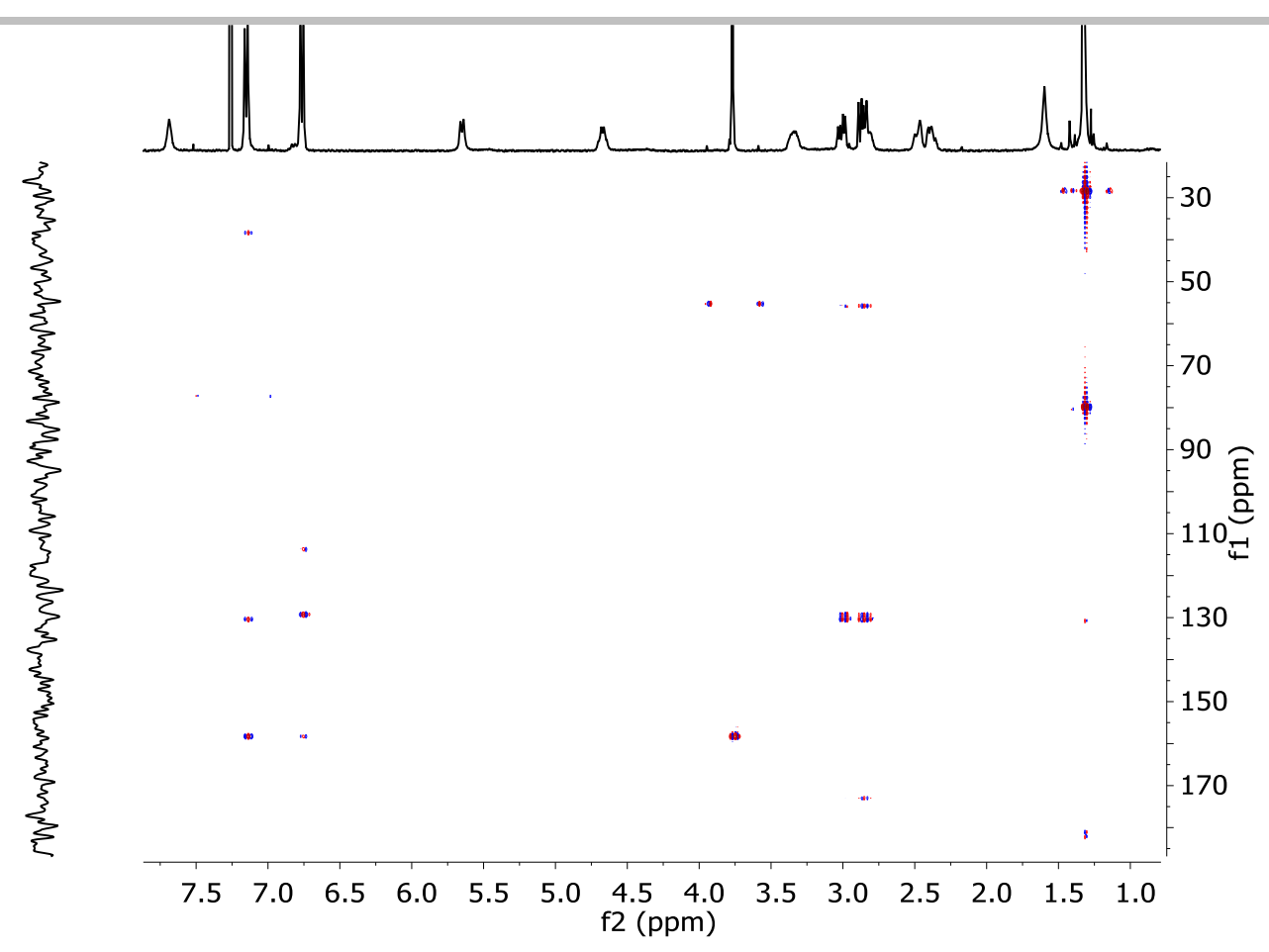

Figure S2. ${ }^{1} \mathrm{H}-\mathrm{NMR}\left(400 \mathrm{MHz}, \mathrm{CD}_{3} \mathrm{OD}\right), \mathrm{HSQC}$ and $\mathrm{HMBC}$ spectra of $\mathbf{2 b}$

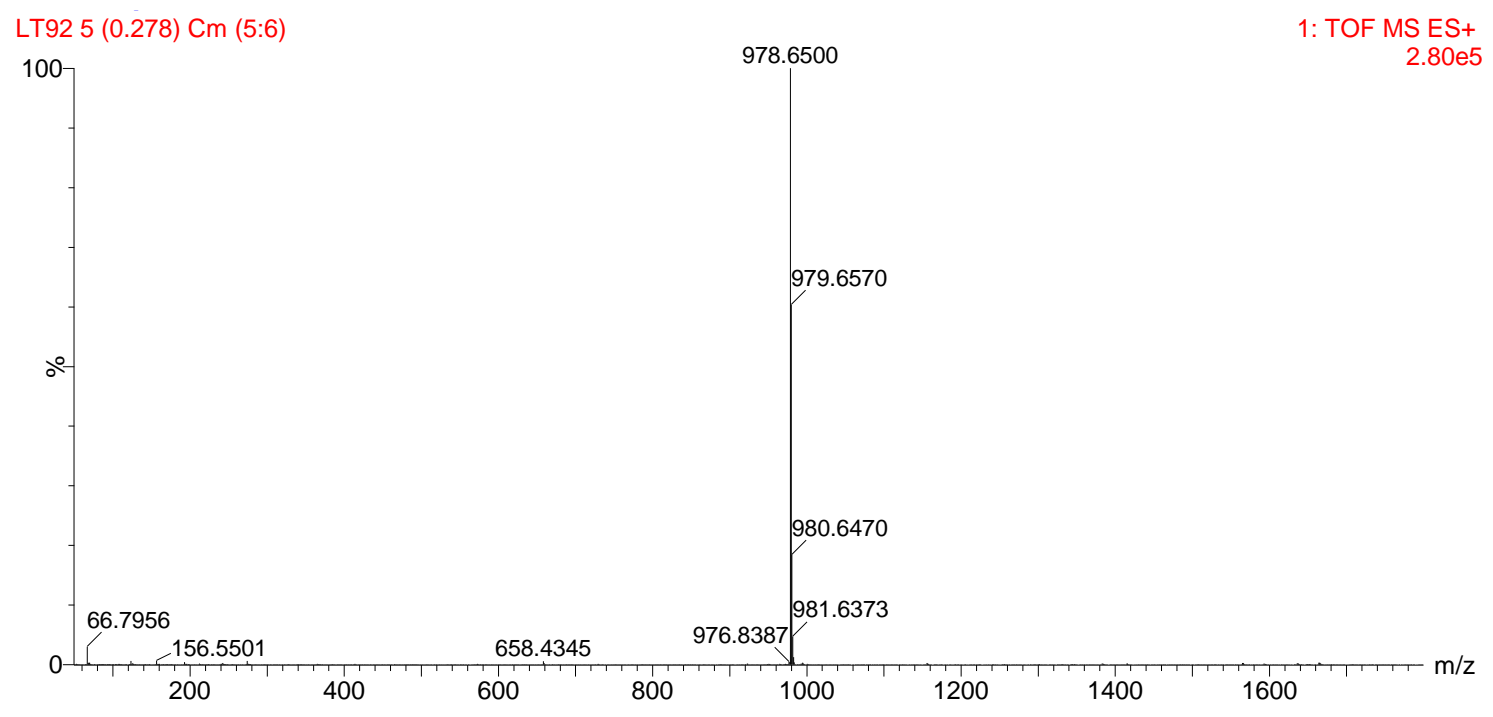

Figure S3. HRMS (ESI+) experimental spectrum of $\mathbf{2 b}$. 
<smiles>COc1ccc(C[C@H](N)C(=O)NCCN(CCNC(=O)[C@H](N)Cc2ccc(OC)cc2)CCNC(=O)[C@H](N)Cc2ccc(OC)cc2)cc1</smiles>

Figure S4. Structure of $3 \mathbf{b}$.

2b (153 mg, $0.156 \mathrm{mmol})$ was dissolved in DCM (1.5 ml). Triethylsilane $(0.35 \mathrm{~mL}, 2.34 \mathrm{mmol})$ and trifluoroacetic acid $(1 \mathrm{~mL})$ were then added. The solution was stirred at room temperature during 3 hours and then solvents were evaporated under an air current affording a yellow oil. The residue was washed several times with diethyl ether and dried affording $3 \mathbf{b} \cdot 4$ TFA as a white solid (166 mg, 0.145 $\mathrm{mmol}, 93 \%$ yield). The resulting solid was dissolved in $\mathrm{NaOH} 1 \mathrm{M}$ and extracted with ethyl acetate to eliminate the TFA and obtain the free amine.

${ }^{1} \mathrm{H}$ NMR $\left(400 \mathrm{MHz}, \mathrm{CD}_{3} \mathrm{OD}\right): \delta(\mathrm{ppm})=7.18(\mathrm{~d}, \mathrm{~J}=8.7 \mathrm{~Hz}, 6 \mathrm{H}), 6.91(\mathrm{~d}, \mathrm{~J}=8.7 \mathrm{~Hz}, 6 \mathrm{H}), 4.03$ (X subsystem from $A B X, J_{A B}=7.3, J_{B X}=7.4$ $\mathrm{Hz}, 3 \mathrm{H}$ ), $3.79(\mathrm{~s}, 9 \mathrm{H}), 3.29(\mathrm{~m}, 6 \mathrm{H}), 3.12$ (B subsystem from $A B X, J_{A B}=14.1, J_{B X}=7.4 \mathrm{~Hz}, 3 \mathrm{H}$ ), 3.00(A subsystem from $A B X, J_{A B}=14.1$, $\left.J_{A X}=7.3 \mathrm{~Hz}, 3 \mathrm{H}\right), 2.65(\mathrm{~m}, 6 \mathrm{H})$.

${ }^{13} \mathrm{C}$ NMR $\left(101 \mathrm{MHz}, \mathrm{CD}_{3} \mathrm{OD}\right): \delta(\mathrm{ppm})=197.9,187.4,158.7,154.1,142.5,83.4,82.9,81.3,64.7,63.5$.

HRMS (ESI-TOF) m/z [3b + H] Calc.: 678.3974 , found: 678.4558

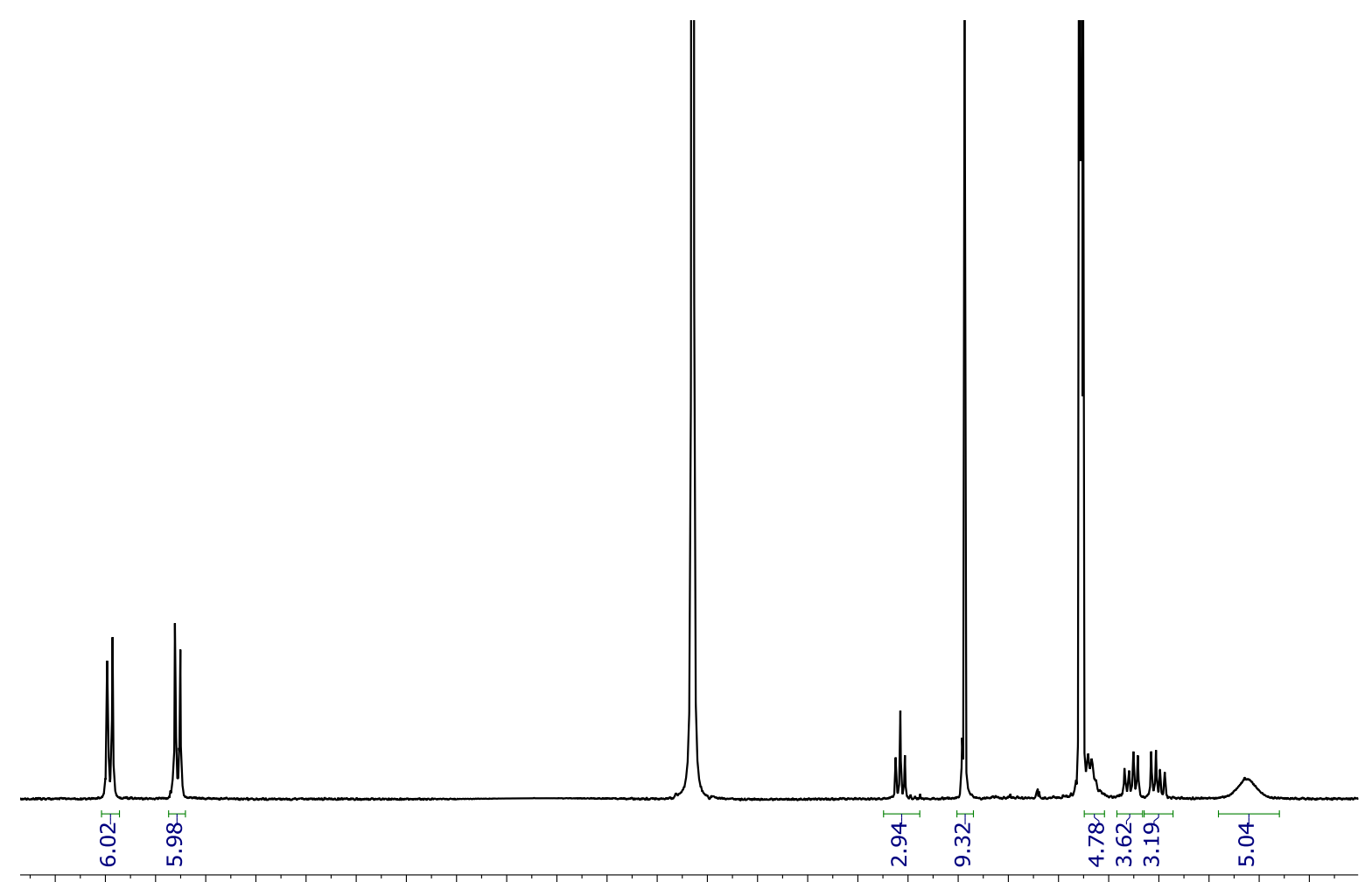

7.4 7.2 7.0 6.8 6.6 6.4 6.2 6.0 5.8 5.6 5.4 5.2 5.0 4.8 4.6 4.4 4.2 4.0 3.8 3.6 3.4 3.2 3.0 2.8 2.6 2.4 f1 (ppm) 

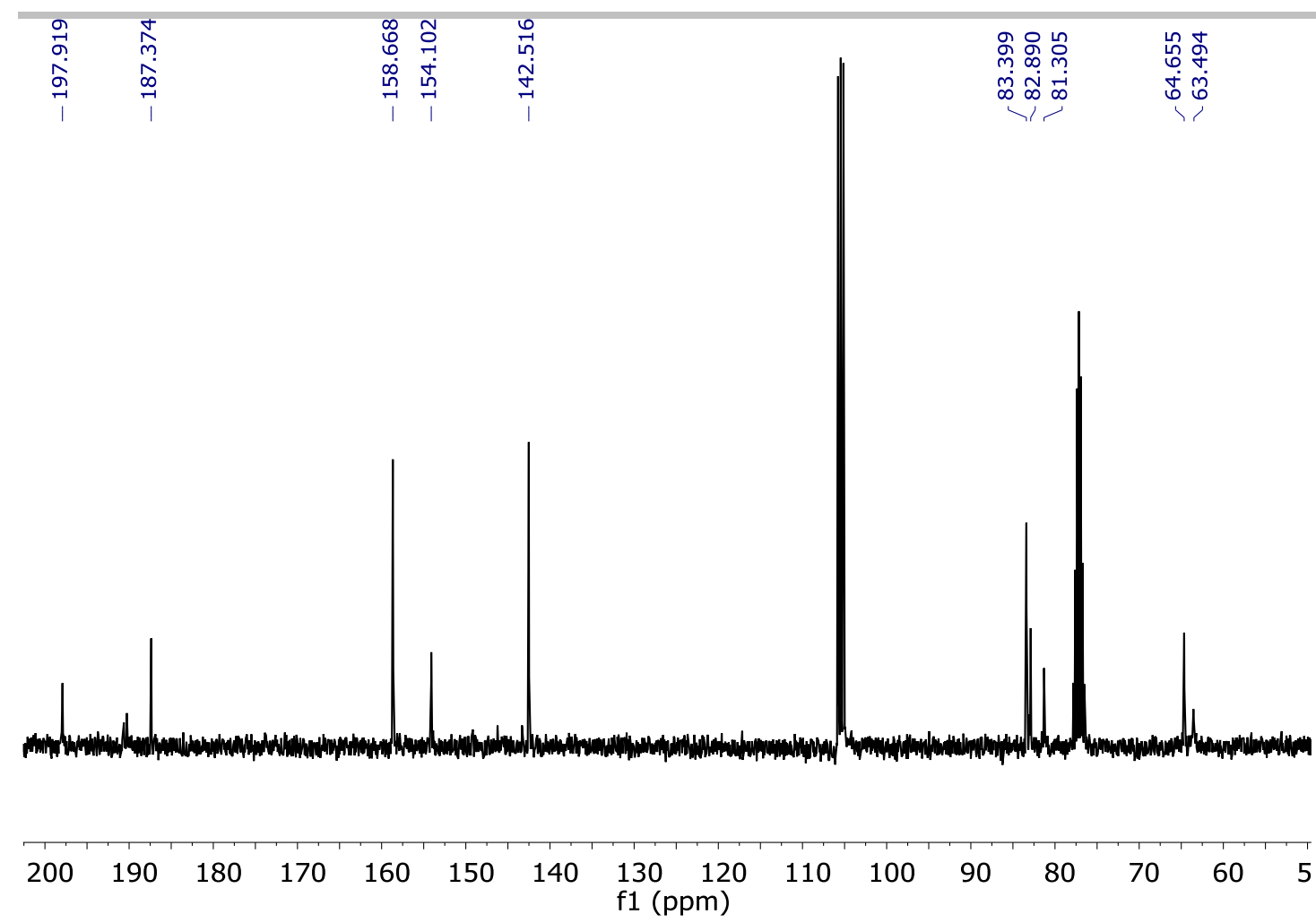

Figure S5. ${ }^{1} \mathrm{H}-\mathrm{NMR}\left(400 \mathrm{MHz}, \mathrm{CD}_{3} \mathrm{OD}\right)$ spectra of $\mathbf{3 b} \cdot \mathbf{4 T F A}$. and ${ }^{13} \mathrm{C}-\mathrm{NMR}\left(101 \mathrm{MHz}, \mathrm{CD}_{3} \mathrm{Cl}\right)$ spectra of $\mathbf{3} \mathbf{b}$.

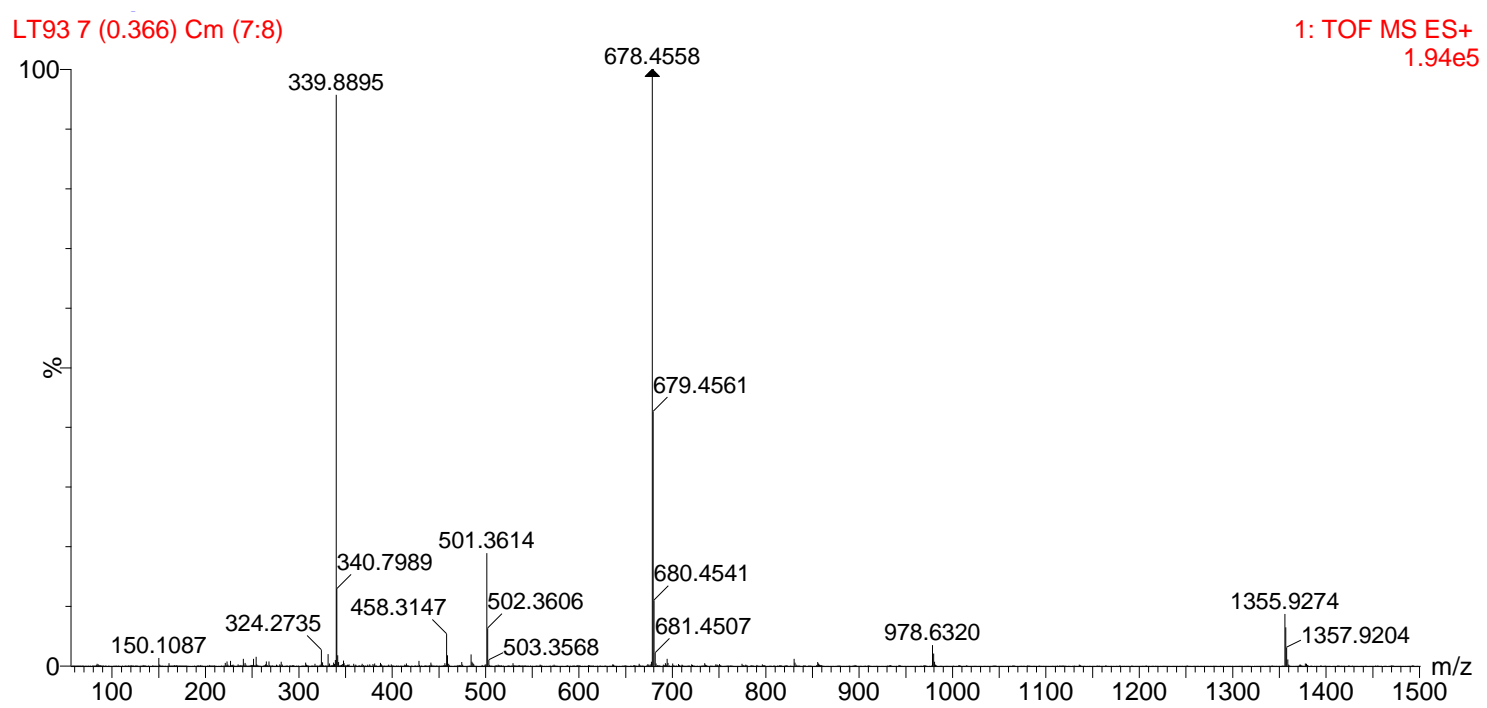

Figure S6. HRMS (ESI+) experimental spectrum of $\mathbf{3 b} \cdot \mathbf{4 T F A}$. 


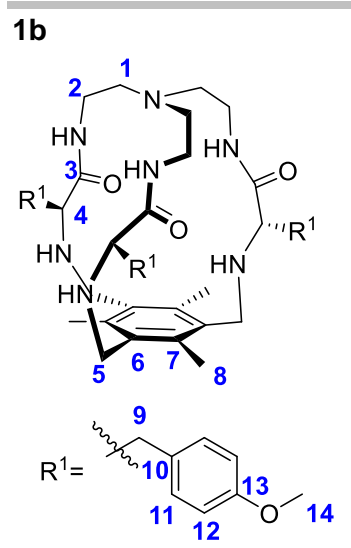

Figure S7. Structure of $\mathbf{1 b}$.

3b (143.2 mg, $0.126 \mathrm{mmol})$ was dissolved in dry acetonitrile $(50 \mathrm{~mL}) . \mathrm{Bu}_{4} \mathrm{Cl}(34 \mathrm{mg}, 0.076 \mathrm{mmol})$ and $\mathrm{K}_{2} \mathrm{CO}_{3}(349 \mathrm{mg}, 3 \mathrm{mmol})$ were added to the solution. 1,3,5-tris(bromomethyl)-2,4,6-trimethylbenzene (50 mg, $0.126 \mathrm{mmol}$ ) was dissolved in acetonitrile (10 mL) and the solution was added to the reaction containing $\mathbf{3 b}$. Reaction mixture refluxed for 16 hours. Solvent was evaporated and the resulting crude was purified by flash chromatography The residue was purified by flash chromatography using DCM:MeOH 95:5 as eluent to give $1 \mathrm{~b}$ (43 mg, $50 \mathrm{mmol}, 40 \%$ yield).

${ }^{1} \mathrm{H}$ NMR $\left(400 \mathrm{MHz}, \mathrm{CD}_{3} \mathrm{Cl}\right): \delta(\mathrm{ppm})=7.23(\mathrm{~d}, \mathrm{~J}=8.6 \mathrm{~Hz}, 6 \mathrm{H}, \mathrm{H12}), 7.18(\mathrm{~m}, 3 \mathrm{H}, \mathrm{NH}), 6.89$ (d, J=8.6 Hz, 6H, H11), 3.81 (s, 9H, H14), $3.73\left(\mathrm{AB}_{\mathrm{q}}, \delta_{\mathrm{A}}=3.77, \delta_{\mathrm{B}}=3.69, J_{A B}=13.6 \mathrm{~Hz}, 6 \mathrm{H}, \mathrm{H} 5\right), 3.42$ (X subsystem from ABX, $\left.J_{A X}=7.5, J_{B X}=4.6 \mathrm{~Hz}, 3 \mathrm{H}, \mathrm{H} 4\right), 3.22$ (B subsystem from $\left.A B X, J_{A B}=4.0, J_{B X}=4.6 \mathrm{~Hz}, 3 \mathrm{H}, \mathrm{H} 9\right), 2.97(\mathrm{~m}, 6 \mathrm{H}, \mathrm{H} 2$ and A subsystem from ABX H9 overlapped), 2.65 (m, $6 \mathrm{H}, \mathrm{H} 1 \mathrm{H} 2), 2.34$ (m, $3 \mathrm{H}, \mathrm{H} 1), 2.29$ (s, 9H, H14).

${ }^{13} \mathrm{C} \mathrm{NMR}\left(100 \mathrm{MHz}, \mathrm{CDCl}_{3}\right): \delta(\mathrm{ppm})=174.2$ (C3), 158.5 (C7), 135.1 (C6), 130.7 (C12), 130.5 (C10), 129.6 (C13), 114.3 (C11), 63.5 (C4), 57.6 (C1), 55.3 (C14), 46.3 (C5), 41.0 (C2), 37.1 (C9), 15.3 (C8). (Data obtained from HSQC and HMBC spectra)

HRMS (ESI-TOF) m/z [1 $1 \mathrm{~b}+\mathrm{H}]^{+}$Calc.: 834.4913 , found: 834.5082

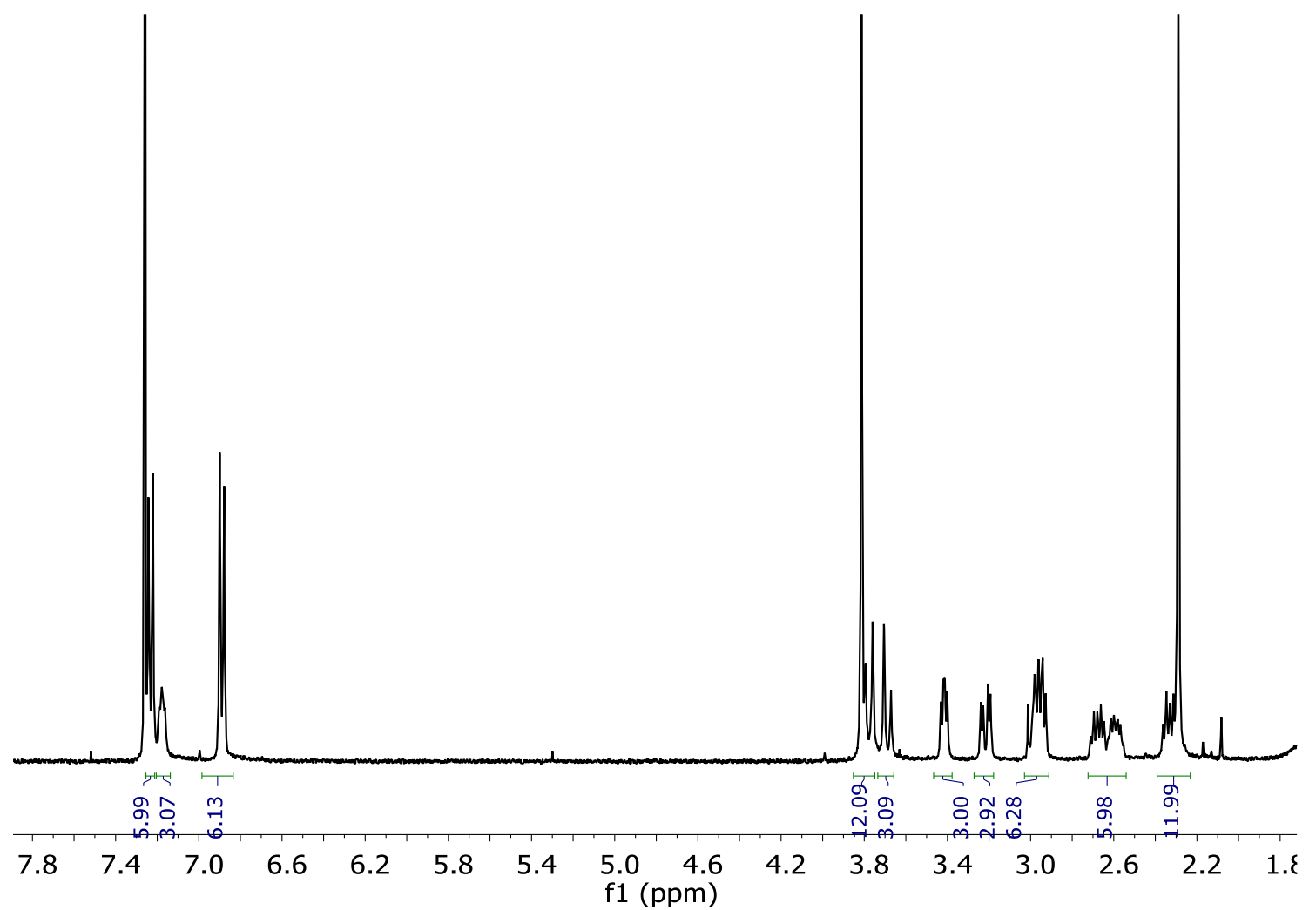



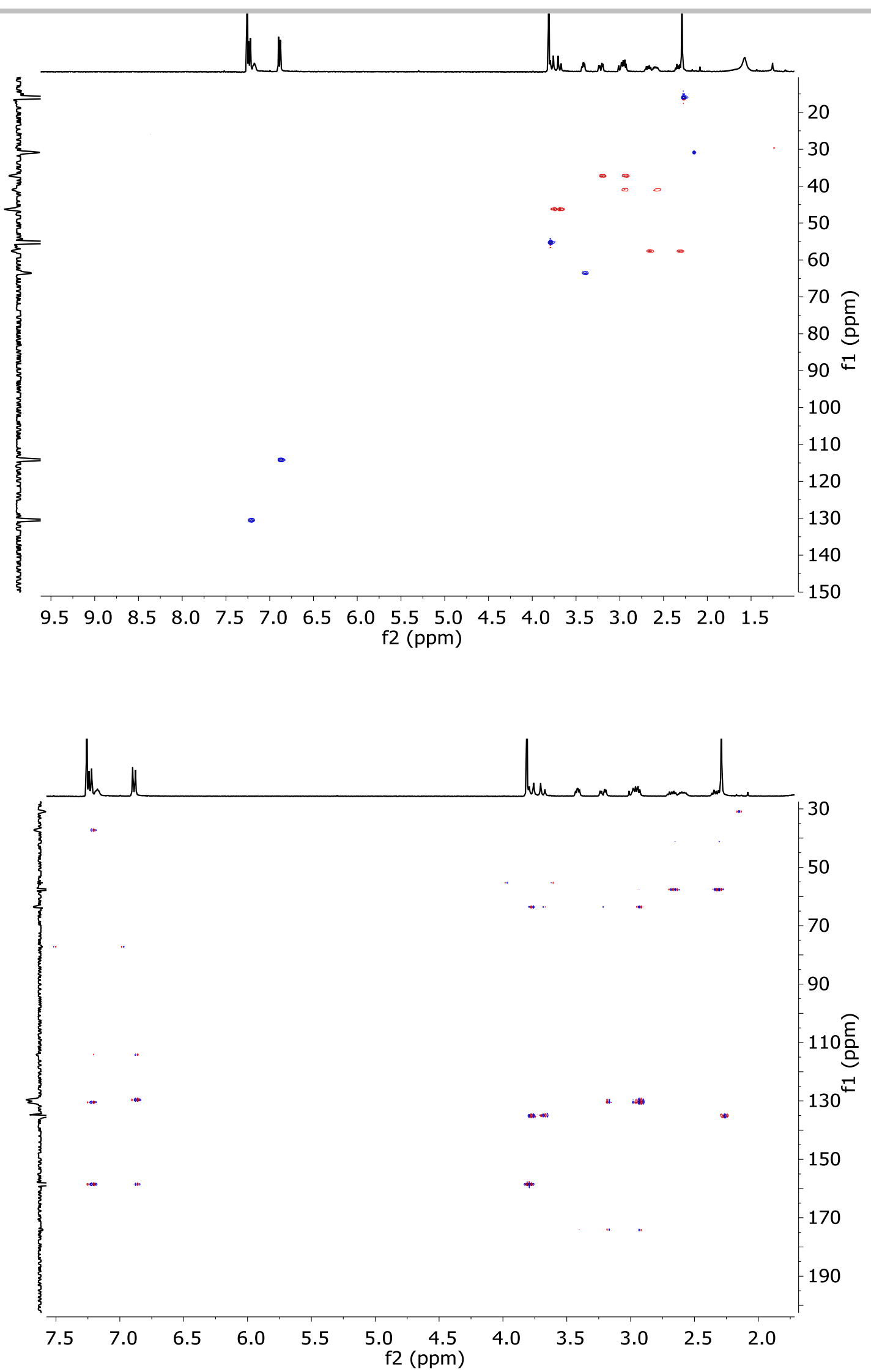

Figure S8. ${ }^{1} \mathrm{H}-\mathrm{NMR}\left(400 \mathrm{MHz}, \mathrm{CD}_{3} \mathrm{OD}\right), \mathrm{HSQC}$ and $\mathrm{HMBC}$ spectra of $\mathbf{1 b}$. 


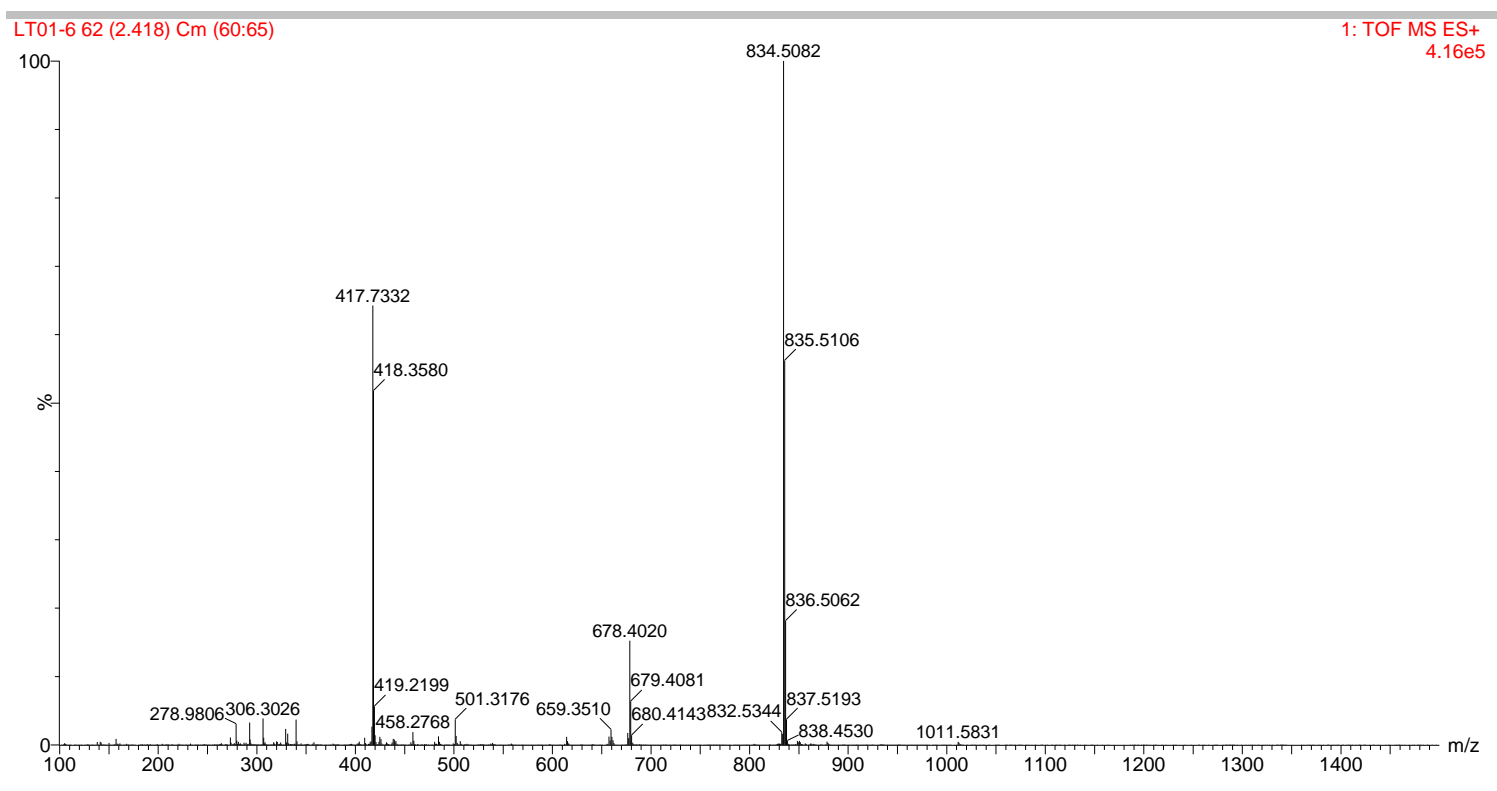

Figure S9. HRMS (ESI+) experimental spectrum of 1b. 
<smiles>CC(C)(C)OC(=O)NC(Cc1ccc(F)cc1)C(=O)O</smiles>

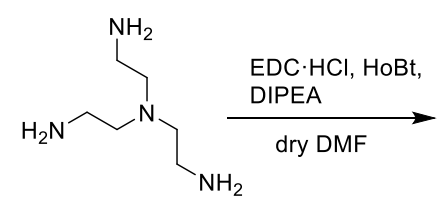<smiles>CC(C)OC(C)(C)OC(=O)C(Cc1ccc(F)cc1)NC(=O)C(Cc1ccc(F)cc1)NC(=O)C(Cc1ccc(F)cc1)NCCN(CCNC(=O)OC(C)(C)C)CCNC(=O)[C@H](Cc1ccc(F)cc1)NC(=O)OC(C)(C)C</smiles><smiles>NC(Cc1ccc(F)cc1)C(=O)NCCN(CCNC(=O)[C@H](N)Cc1ccc(F)cc1)CCNC(=O)[C@H](N)Cc1ccc(F)cc1</smiles><smiles>[R]c1c(CBr)c([R])c(CBr)c([R])c1CBr</smiles>

$\left(R^{2}=\mathrm{Me}\right)$

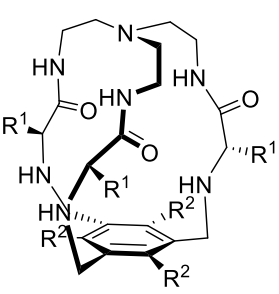

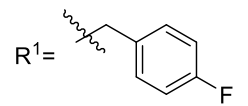

Scheme S2. Full synthetic scheme of 1c.

2c tri-tert-butyl ((2S,2'S,2"S)-((nitrilotris(ethane-2,1-diyl))tris(azanediyl))tris(3-(4-fluorophenyl)-1-oxopropane-1,2diyl))tricarbamate<smiles>CC(C)(C)OC(=O)N[C@@H](Cc1ccc(F)cc1)C(=O)NCCN(CCNC(=O)[C@H](Cc1ccc(F)cc1)NC(=O)OC(C)(C)C)CCNC(=O)[C@H](Cc1ccc(F)cc1)NC(=O)OC(C)(C)C</smiles>

Figure S10. Structure of $2 c$

Boc-Phe(4-F)-OH (299 mg, $1.057 \mathrm{mmol})$ was dissolved in dry DMF (2.5 mL). N-(3-dimethylaminopropyl)- $N$ '-ethylcarbodiimide hydrochloride (EDC. $\mathrm{HCl} 0.254 \mathrm{mg}, 1.28 \mathrm{mmol}$ ) and 1-Hydroxybenzotriazole hydrate (HOBt, $0.196 \mathrm{mg}, 1.28 \mathrm{mmol}), \mathrm{N}, \mathrm{N}-$ diisopropylethylamine (DIPEA, $0.67 \mathrm{~mL}, 3.84 \mathrm{mmol})$ and tris $(2$-aminoethyl)amine $(0.05 \mathrm{~mL}, 0.32 \mathrm{mmol})$ were added over the solution. The solution was stirred at room temperature for 16 hours, when no more conversion of the starting material was observed by TLC. The mixture was diluted with water and extracted with DCM $(3 \times 10 \mathrm{~mL})$. Combined organic fractions were washed with aqueous LiCl $(5 \% \mathrm{w} / \mathrm{w})$, dried over $\mathrm{MgSO}_{4}$ and concentrated to dryness. The residue was purified by flash chromatography using 95:5 DCM:MeOH to give $0.254 \mathrm{mg}$ of $2 \mathrm{c}(0.239 \mathrm{mmol}, 85 \%$ yield $)$.

${ }^{1} \mathrm{H}$ NMR $\left(400 \mathrm{MHz}, \mathrm{CD}_{3} \mathrm{Cl}\right): \delta(\mathrm{ppm})=7.72(\mathrm{~s}, 3 \mathrm{H}), 7.20(\mathrm{dd}, \mathrm{J}=8.5,5.5 \mathrm{~Hz}, 6 \mathrm{H}), 6.90(\mathrm{t}, \mathrm{J}=8.7 \mathrm{~Hz}, 2 \mathrm{H}), 5.71(\mathrm{~d}, J=9.0 \mathrm{~Hz}, 3 \mathrm{H}), 4.70(\mathrm{X}$ subsystem from $\left.A B X J_{A X}=13.7, J_{B X}=8.8 \mathrm{~Hz}, 3 \mathrm{H}\right), 3.35(\mathrm{~m}, 3 \mathrm{H}), 3.02$ (A subsystem from $\left.A B X, J_{A X}=13.7, J_{A B}=6.4 \mathrm{~Hz}, 3 \mathrm{H}\right), 2.87(B$ subsystem from $\left.A B X J_{B X}=8.8 \mathrm{~Hz} J_{A B}=6.4 \mathrm{~Hz}, 3 \mathrm{H}\right), 2.79(\mathrm{~m}, 3 \mathrm{H}), 2.43(\mathrm{~m}, 6 \mathrm{H}), 1.32(\mathrm{~s}, 27 \mathrm{H})$.

${ }^{13} \mathrm{C}$ NMR $\left(101 \mathrm{MHz}, \mathrm{CD}_{3} \mathrm{Cl}\right): \delta(\mathrm{ppm})=173.0,156.4,131.1,131.0,115.2,115.0,80.1,55.8,55.1,39.0,38.7,28.4$. 

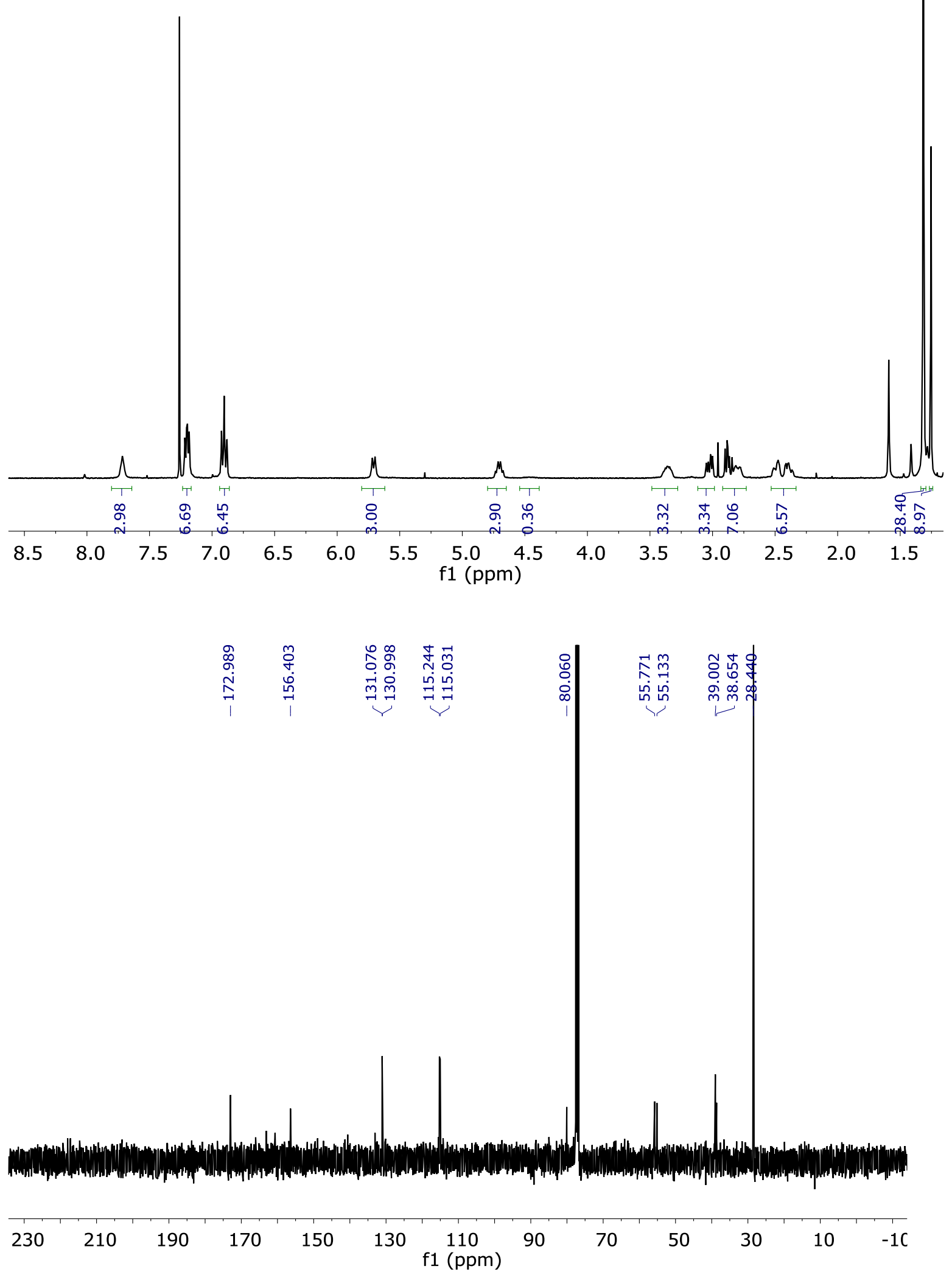

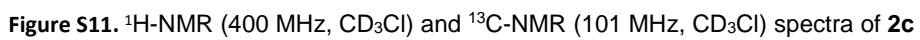




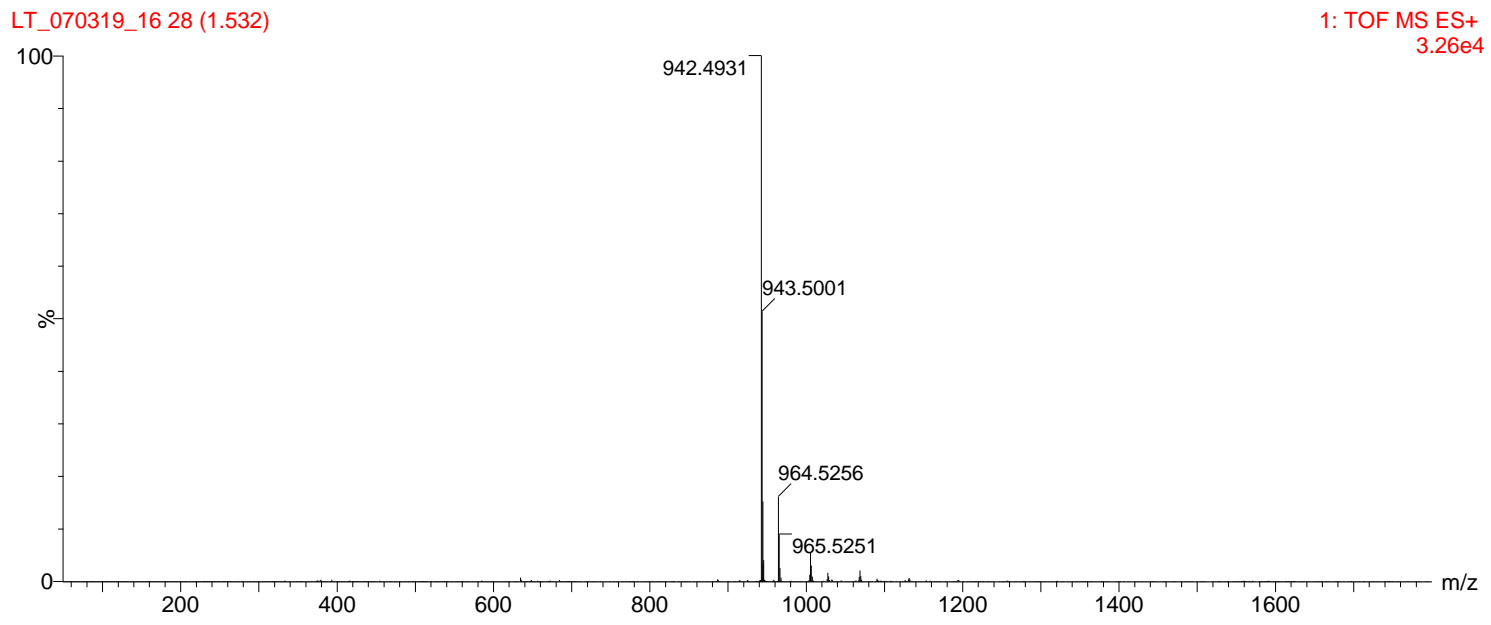

Figure S12. HRMS (ESI+) experimental spectrum of 2c. 


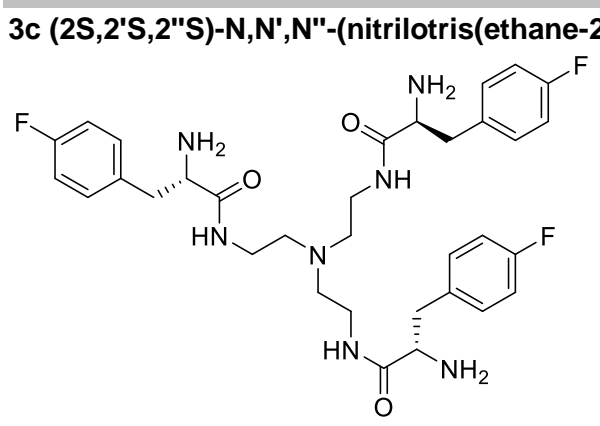

Figure S13. Structure of $3 \mathrm{c}$

2c $(173 \mathrm{mg}, 0.183 \mathrm{mmol})$ was dissolved in DCM $(1 \mathrm{~mL})$ and triethylsilane (TES, $0.414 \mathrm{~mL}, 2.756 \mathrm{mmol})$ and TFA (1mL) were added. The solution was stirred at room temperature for 3 hours. The solvents were then evaporated under an air current affording a yellow oil. The residue was washed several times with diethyl ether and dried affording 3c.4TFA as a white solid (166 mg, $0.145 \mathrm{mmol}, 93 \%$ yield).

${ }^{1} \mathrm{H}$ NMR $\left(400 \mathrm{MHz}, \mathrm{CD}_{3} \mathrm{OD}\right): \delta(\mathrm{ppm})=7.33(\mathrm{dd}, \mathrm{J}=8.5,5.2 \mathrm{~Hz}, 6 \mathrm{H}), 7.09$ (t, J=8.7 Hz, 6H), 4.13 (X subsystem from ABX, JAX=7.2, $J_{B X}=7,6 \mathrm{~Hz}, 3 \mathrm{H}$ ), $3.33\left(\mathrm{~m}, 6 \mathrm{H}\right.$ ), 3.16 (A subsystem from $A B X$, $J_{A X}=7.2, J_{A B}=14 \mathrm{~Hz}, 3 \mathrm{H}$ ), 3.07 (B subsystem from $A B X, J_{B X}=7.6, J_{A B}=14$ $\mathrm{Hz}, 3 \mathrm{H}) 2.59(\mathrm{~m}, 6 \mathrm{H})$

${ }^{13} \mathrm{C} N M R\left(101 \mathrm{MHz}, \mathrm{CD}_{3} \mathrm{OD}\right): \delta(\mathrm{ppm})=168.5,131.0,130.1,115.5,115.3,54.3,52.6,36.4$.

HRMS (ESI-TOF) m/z [3c+ H]+ Calc.: 642.3374, found: 642.3666

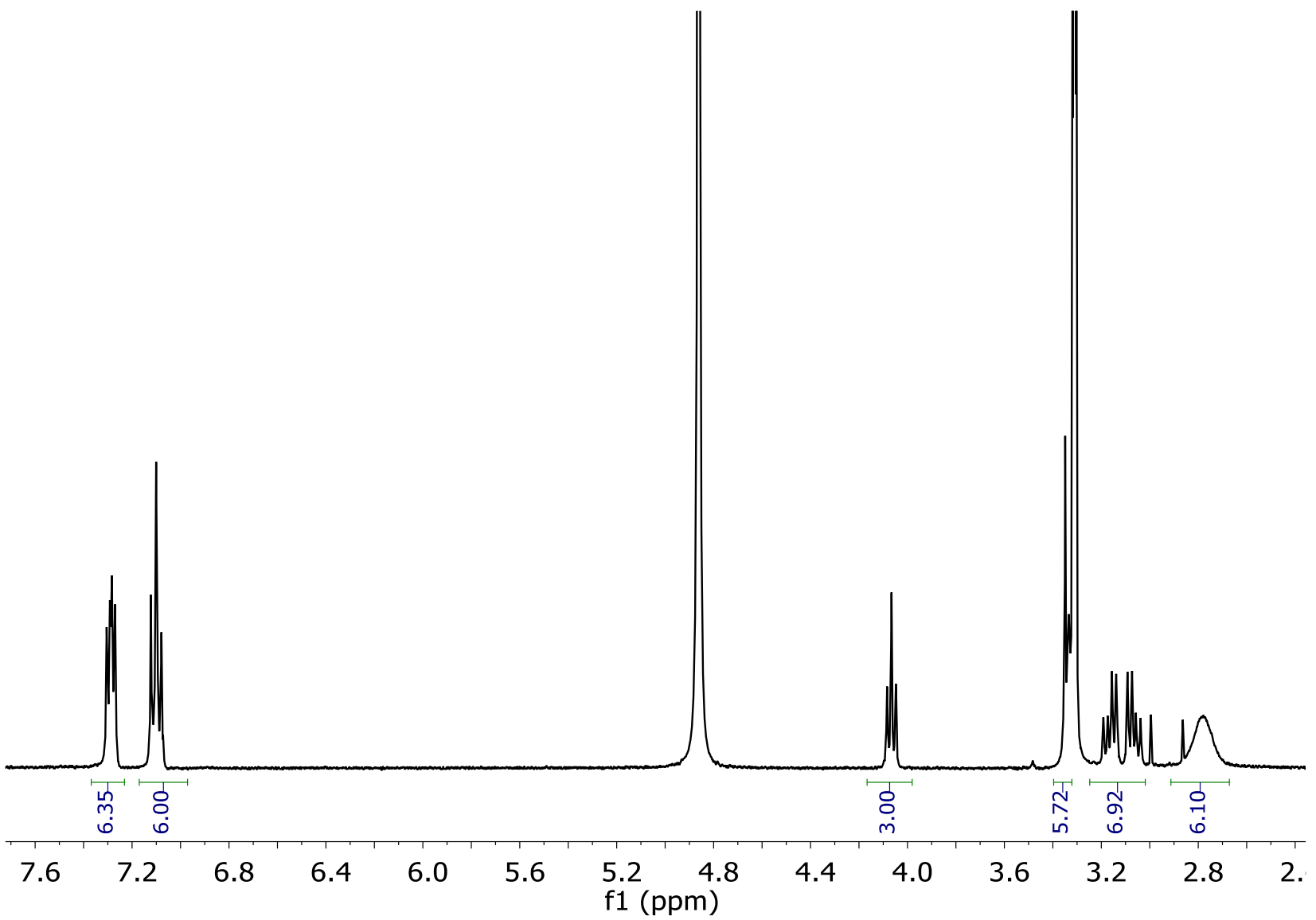




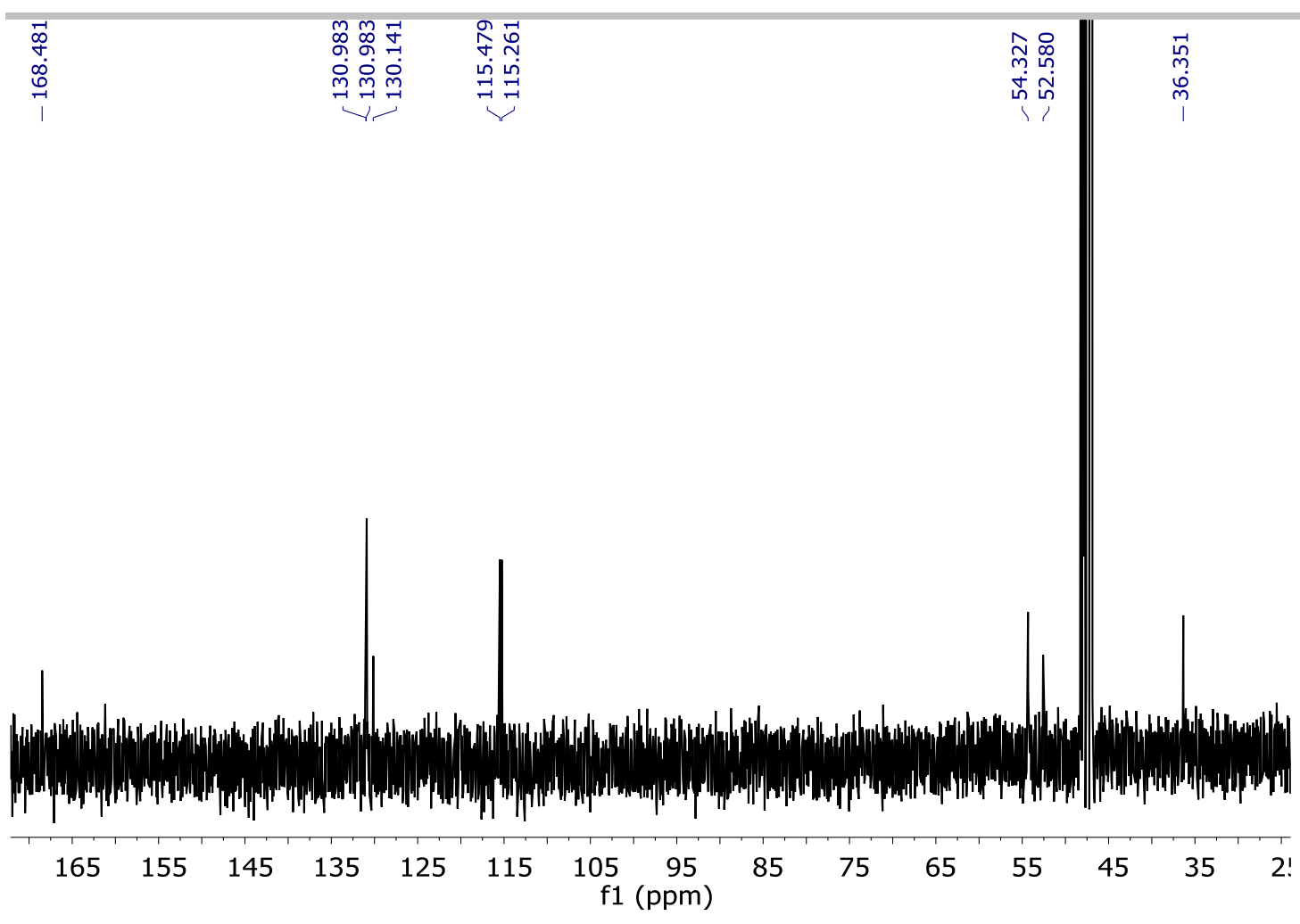

Figure S14. ${ }^{1 \mathrm{H}-\mathrm{NMR}}\left(400 \mathrm{MHz}\right.$, methanol- $\left.\mathrm{d}_{3}\right)$ and ${ }^{13} \mathrm{C}-\mathrm{NMR}\left(101 \mathrm{MHz}\right.$, methanol- $\left.\mathrm{d}_{3}\right)$ spectra of $3 \mathrm{c}$

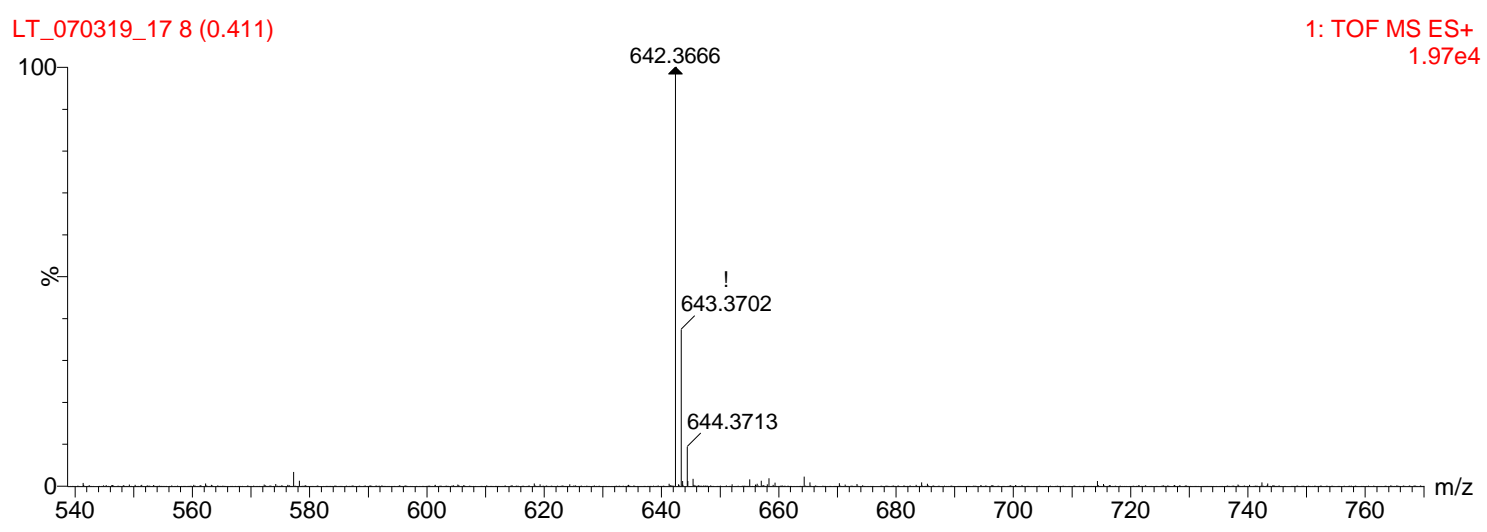

Figure S15. HRMS (ESI+) experimental spectrum of 3c. 


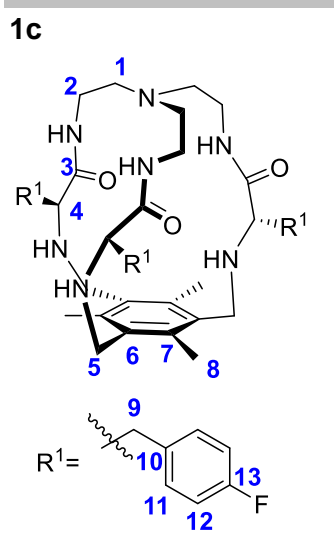

Figure S16. Structure of 1c

3c (173 mg, $0.158 \mathrm{mmol}$ ) was dissolved in ACN (40 mL). Tetrabuthylamonium chloride (22 mg, $0.079 \mathrm{mmol})$, 1,3,5-tris(bromomethyl)2,4,6-trimethylbenzene ( $62 \mathrm{mg}, 0.158 \mathrm{mmol}$ ) and potassium carbonate $(435 \mathrm{mg}, 3.15 \mathrm{mmol}$ ) were added over the solution. The reaction mixture was refluxed for 16 hours. After cooling down, the solution was filtered, solvent was evaporated and the resulting crude was purified by flash column chromatography DCM:MeOH 95:5 as eluent to give 1c (47mg, 59 mmol, 40\% yield).

${ }^{1} \mathrm{H}$ NMR $\left(400 \mathrm{MHz}, \mathrm{CD}_{3} \mathrm{OD}\right): \delta(\mathrm{ppm})=7.29(\mathrm{~m}, 6 \mathrm{H} \mathrm{H11}), 7.04(\mathrm{~m}, 6 \mathrm{H}, \mathrm{H} 12), 3.79\left(\mathrm{AB}_{\mathrm{q}}, \delta_{\mathrm{A}}=3.80, \delta_{\mathrm{B}}=3.78, \mathrm{~J}_{A B}=14 \mathrm{~Hz}, 6 \mathrm{H}, \mathrm{H5}\right), 3.46(\mathrm{X}$ from $A B X$ subsystem, $J_{A X}=6.3, J_{B X}=6.6 \mathrm{~Hz}, 3 \mathrm{H}, \mathrm{H} 4$ ), 3.11 (A subsystem from $A B X, J_{A X}=6.3, J_{A B}=3.7 \mathrm{~Hz}, 3 \mathrm{H}, \mathrm{H} 9$ ), 3.02 (B subsystem, from $\left.A B X J_{B X=6.6,} J_{A B}=3.7 \mathrm{~Hz}, 3 \mathrm{H}, \mathrm{H} 9\right), 2.86(\mathrm{~m}, 3 \mathrm{H}, \mathrm{H} 2), 2.75(\mathrm{~m}, 3 \mathrm{H}, \mathrm{H} 2), 2.43(\mathrm{~m}, 3 \mathrm{H}, \mathrm{H} 1), 2.33(\mathrm{~m}, 3 \mathrm{H}, \mathrm{H} 1), 2.29(\mathrm{~s}, 9 \mathrm{H}, \mathrm{H} 8)$.

${ }^{19} \mathrm{~F} \operatorname{NMR}\left(376 \mathrm{MHz}, \mathrm{CD}_{3} \mathrm{OD}\right): \delta(\mathrm{ppm})=-118.64(\mathrm{~m})$.

${ }^{13} \mathrm{C}$ NMR (101 MHz, CD $\left.{ }_{3} \mathrm{OD}\right): \delta(\mathrm{ppm})=174.5$ (C3), 163.0 and 160,6 (C10, C13), 134.6 (C8), 133.5 (C6), 130.9 (C11), 114.6 (C12), 62.4 (C4), 56.6 (C1), 45.5 (C5), 40.5 (C2), 37.1 (C9), 15.2 (C8).

HRMS (ESI-TOF) m/z [1c+ H] ${ }^{+}$Calc.: 798.4313, found: 798.4435

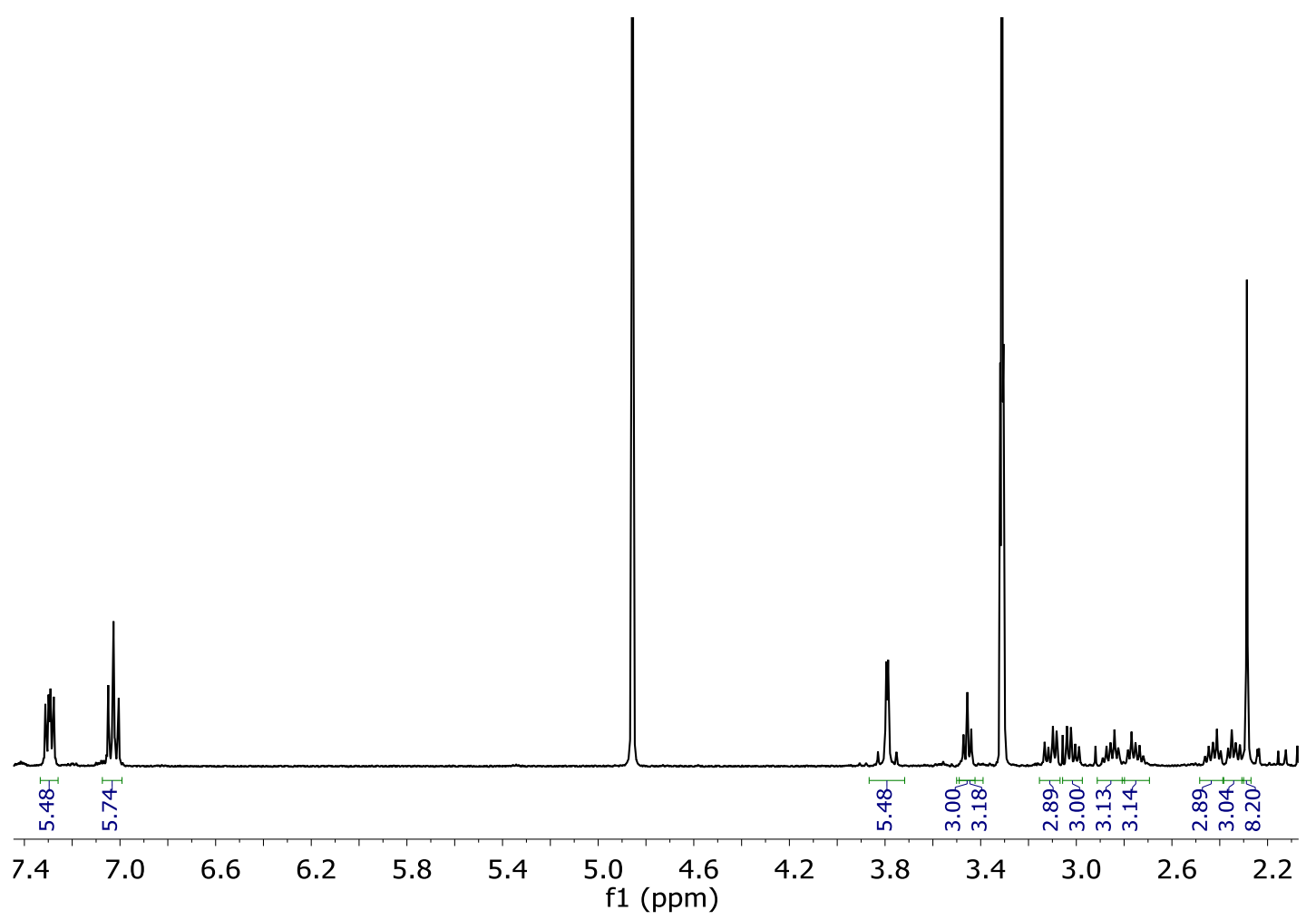




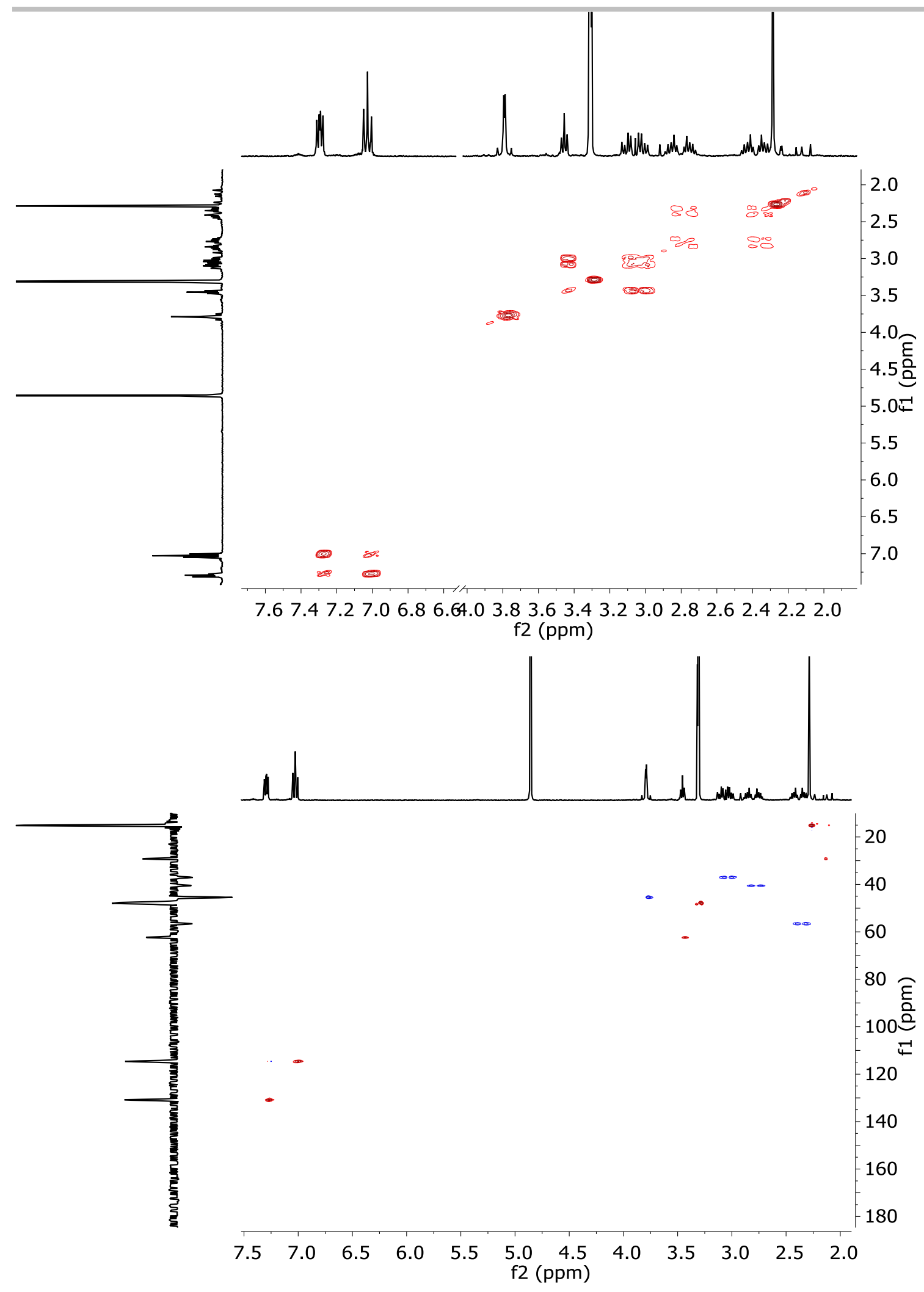




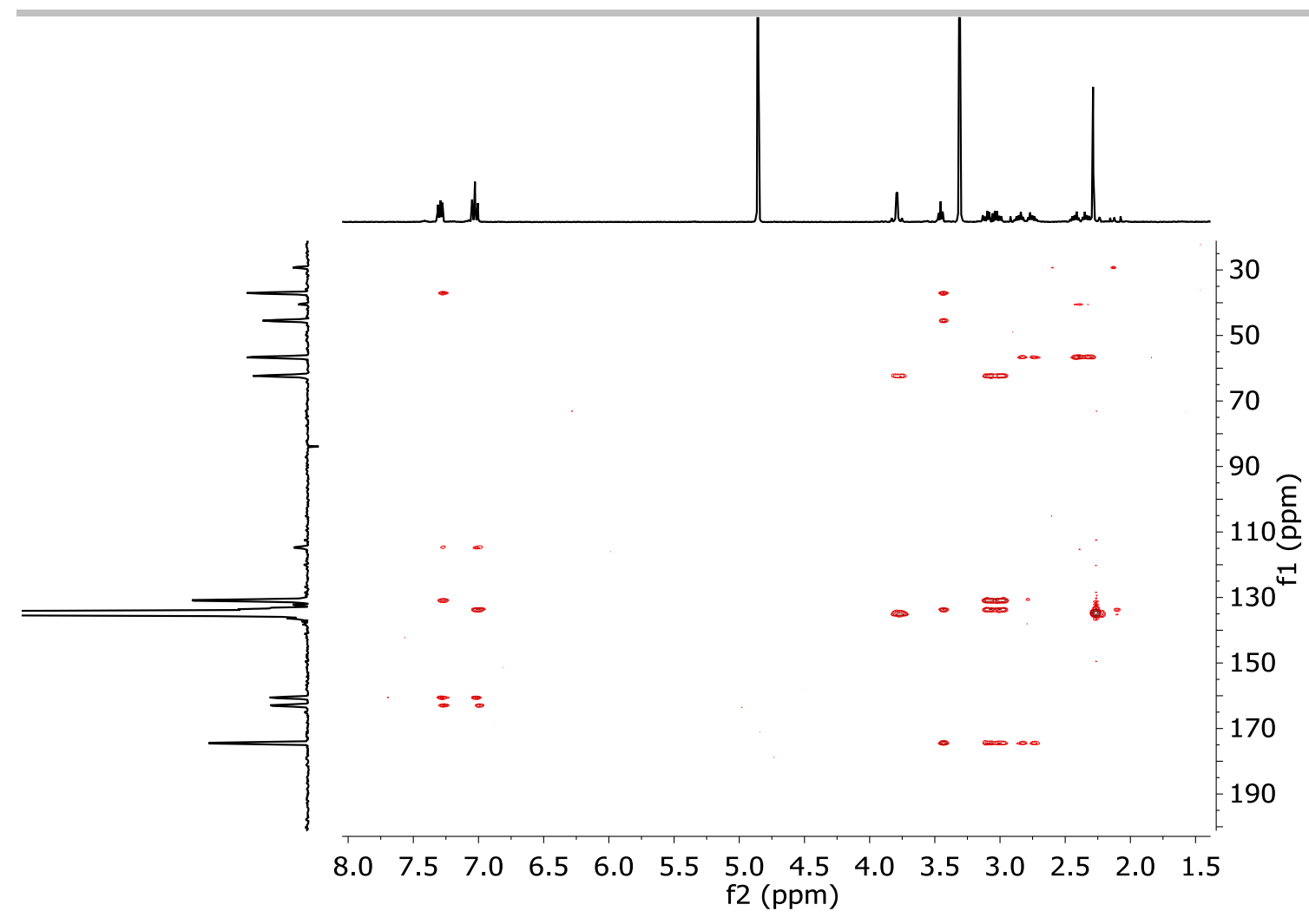

19F NMR (376 MHz, çdd) $\delta-118.61,-118.62,-118.63,-118.65,-118.66,-118.67,-118.68$

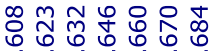

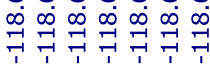

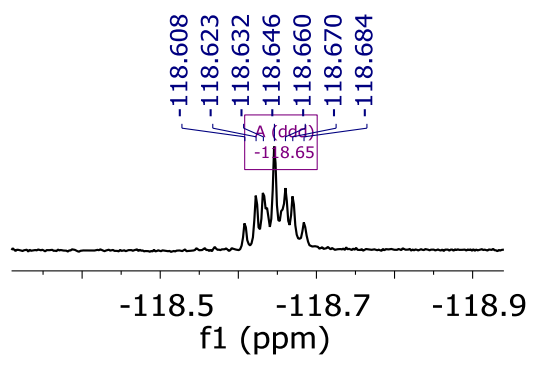

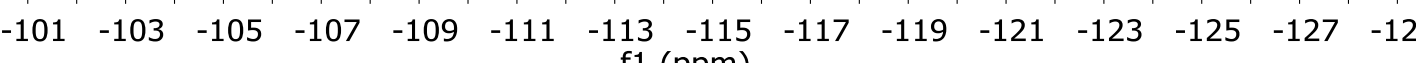
f1 (ppm)

Figure S17. ${ }^{1} \mathrm{H}-\mathrm{NMR}\left(400 \mathrm{MHz}\right.$, methanol- $\left.\mathrm{d}_{3}\right)$, COSY, HSQC, HMBC and ${ }^{19} \mathrm{~F}-\mathrm{NMR}$ spectra of 1c. 


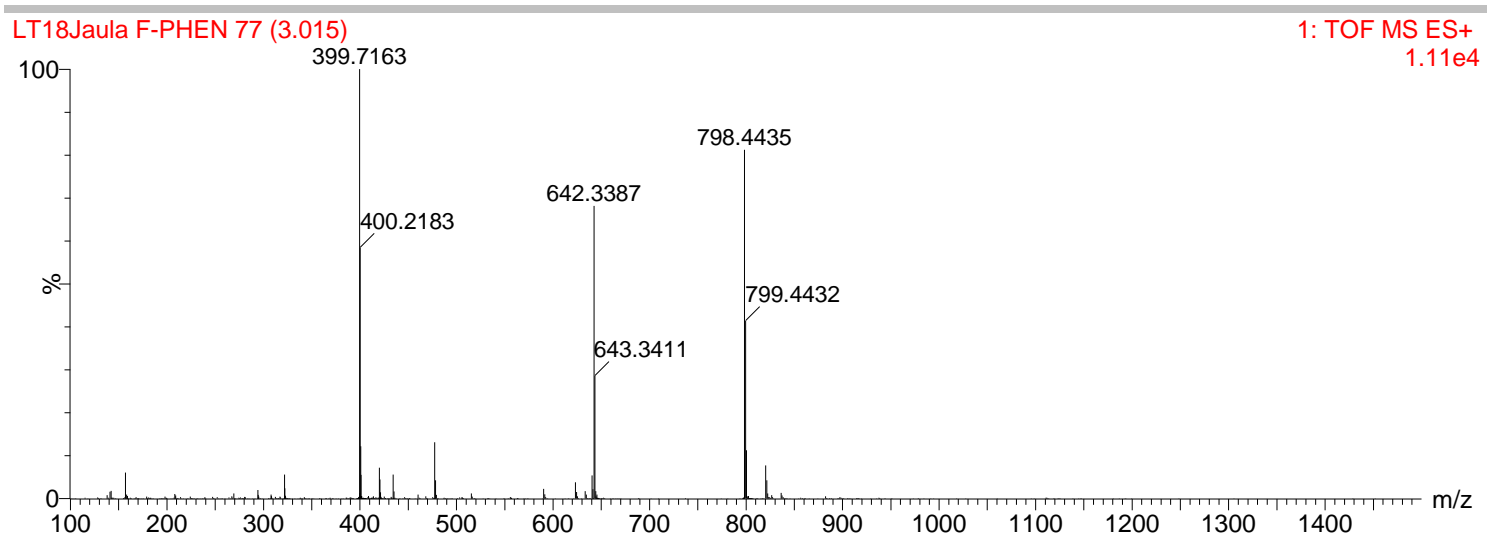

Figure S18. HRMS (ESI+) experimental spectrum of 1c 


\section{Synthesis of 1d}

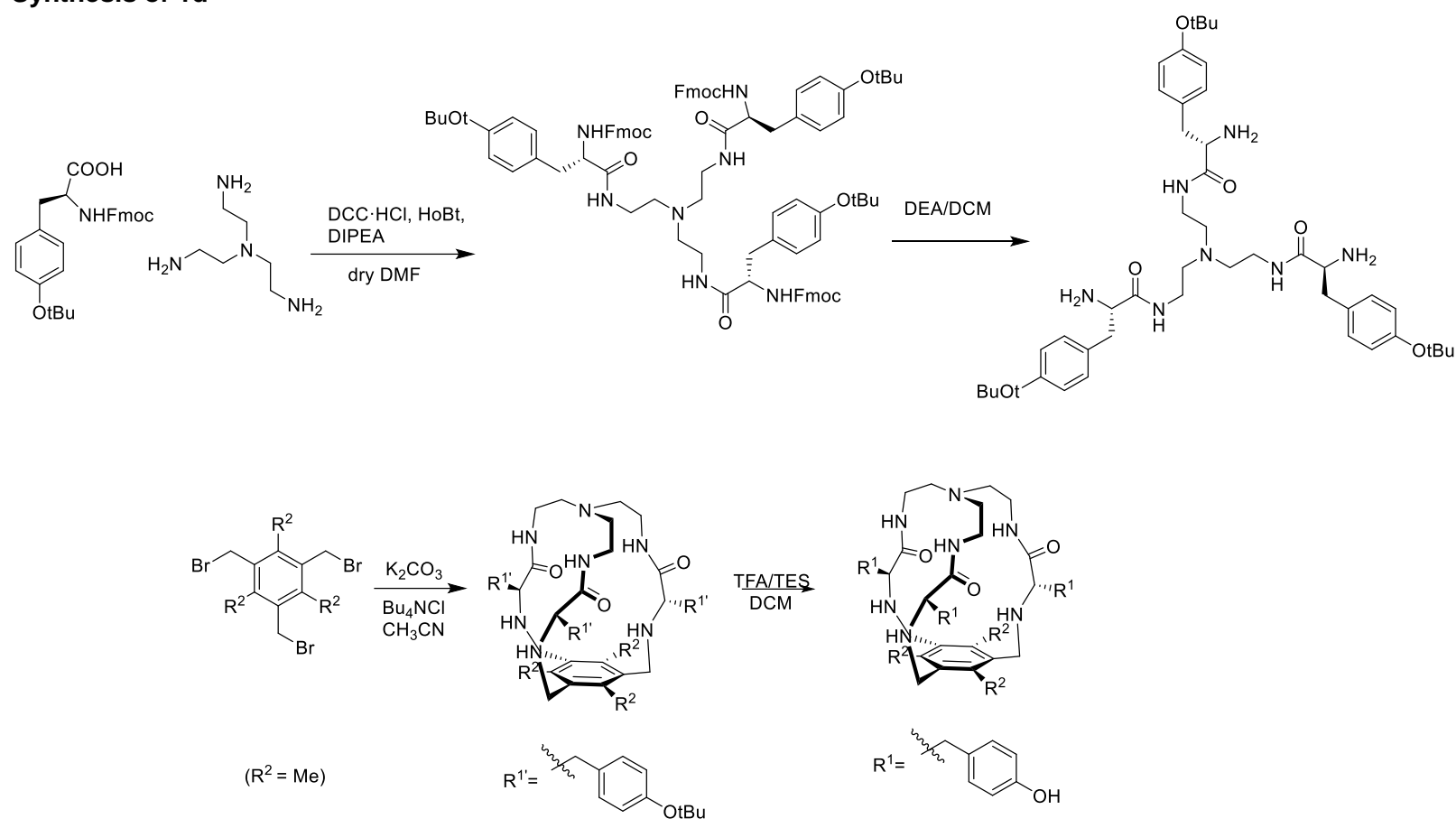

Scheme S3. Full synthetic scheme of 1d

2d tris((9H-fluoren-9-yl)methyl) oxopropane-1,2-diyl))tricarbamate

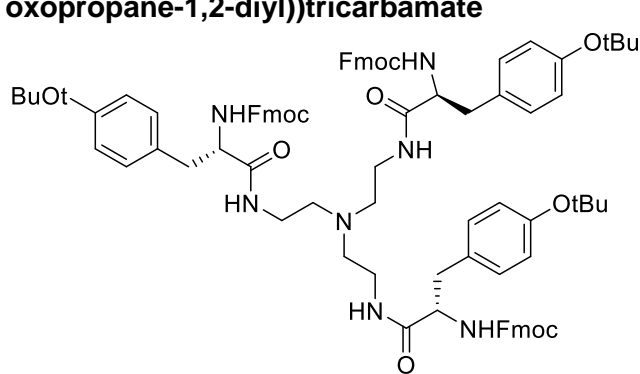

Figure S19. Structure of $\mathbf{2 d}$

Fmoc-L-Tyr(tBu)-OH (767 mg, $1.67 \mathrm{mmol})$ was dissolved in dry DMF (10 mL). N,N'-Dicyclohexylcarbodiimide hydrochloride (DCC.HCl $0.39 \mathrm{mg}, 2.02 \mathrm{mmol}$ ) and 1-hydroxybenzotriazole hydrate (HOBt, $273 \mathrm{mg}, 2.02 \mathrm{mmol}$ ), dissolved in DMF (5 mL) were added over the solution. The solution was stirred at room temperature for 16 hours, when no more conversion of the starting material was observed by TLC. The mixture was then diluted with water and extracted with DCM $(3 \times 10 \mathrm{~mL})$. Combined organic fractions were washed with aqueous $\mathrm{LiCl}(5 \% \mathrm{w} / \mathrm{w})$, dried over $\mathrm{MgSO}_{4}$ and concentrated to dryness. The residue was purified by flash chromatography using DCM:MeOH $97: 3$ to give $614 \mathrm{mg}$ of $2 \mathrm{a}(0.417 \mathrm{mmol}, 81 \%$ yield $)$.

${ }^{1} \mathrm{H}$ NMR $\left(400 \mathrm{MHz}, \mathrm{CD}_{3} \mathrm{Cl}\right): \delta(\mathrm{ppm})=7.65(\mathrm{dd}, J=12.0,7.5 \mathrm{~Hz}, 6 \mathrm{H}), 7.38(\mathrm{t}, J=7.4 \mathrm{~Hz}, 6 \mathrm{H}), 7.32(\mathrm{t}, J=7.4 \mathrm{~Hz}, 6 \mathrm{H}), 7.18(\mathrm{q}, J=8.0 \mathrm{~Hz}$, $6 \mathrm{H}), 7.08(\mathrm{~d}, \mathrm{~J}=8.1 \mathrm{~Hz}, 6 \mathrm{H}), 6.78(\mathrm{~d}, \mathrm{~J}=8.3 \mathrm{~Hz}, 6 \mathrm{H}), 6.02(\mathrm{~d}, \mathrm{~J}=8.7 \mathrm{~Hz}, 3 \mathrm{H}), 4.65(\mathrm{~m}, 3 \mathrm{H}), 4.24(\mathrm{~m}, 3 \mathrm{H}), 4.015(\mathrm{~m}, 9 \mathrm{H}), 3.48(\mathrm{~m}, 3 \mathrm{H})$, $3.20(\mathrm{~m}, 3 \mathrm{H}), 3.01(\mathrm{~m}, 3 \mathrm{H}), 2.87(\mathrm{~m}, 3 \mathrm{H}), 2.77(\mathrm{~m}, 3 \mathrm{H}), 2.36(\mathrm{~m}, 6 \mathrm{H}), 1.94(\mathrm{~m}, 3 \mathrm{H}), 1.70(\mathrm{~m}, 6 \mathrm{H}), 1.69(\mathrm{~m}, 12 \mathrm{H}), 1.36(\mathrm{~m}, 6 \mathrm{H}), 1.23(\mathrm{~s}$, $27 \mathrm{H}), 1.10(\mathrm{~m}, 12 \mathrm{H})$.

${ }^{13} \mathrm{C}$ NMR $\left(101 \mathrm{MHz}, \mathrm{CD}_{3} \mathrm{Cl}\right): \delta(\mathrm{ppm})=172.6,156.7,154.2,143.8,141.2,131.8,129.9,127.8,127.2,125.3,124.213,120.0,78.3,67.5$, $56.3,54.5,46.9,38.8,28.9$.

HRMS (ESI-TOF) m/z [2d+ H] ${ }^{+}$Calc.: 1471.9190, found: 1471.7548. 

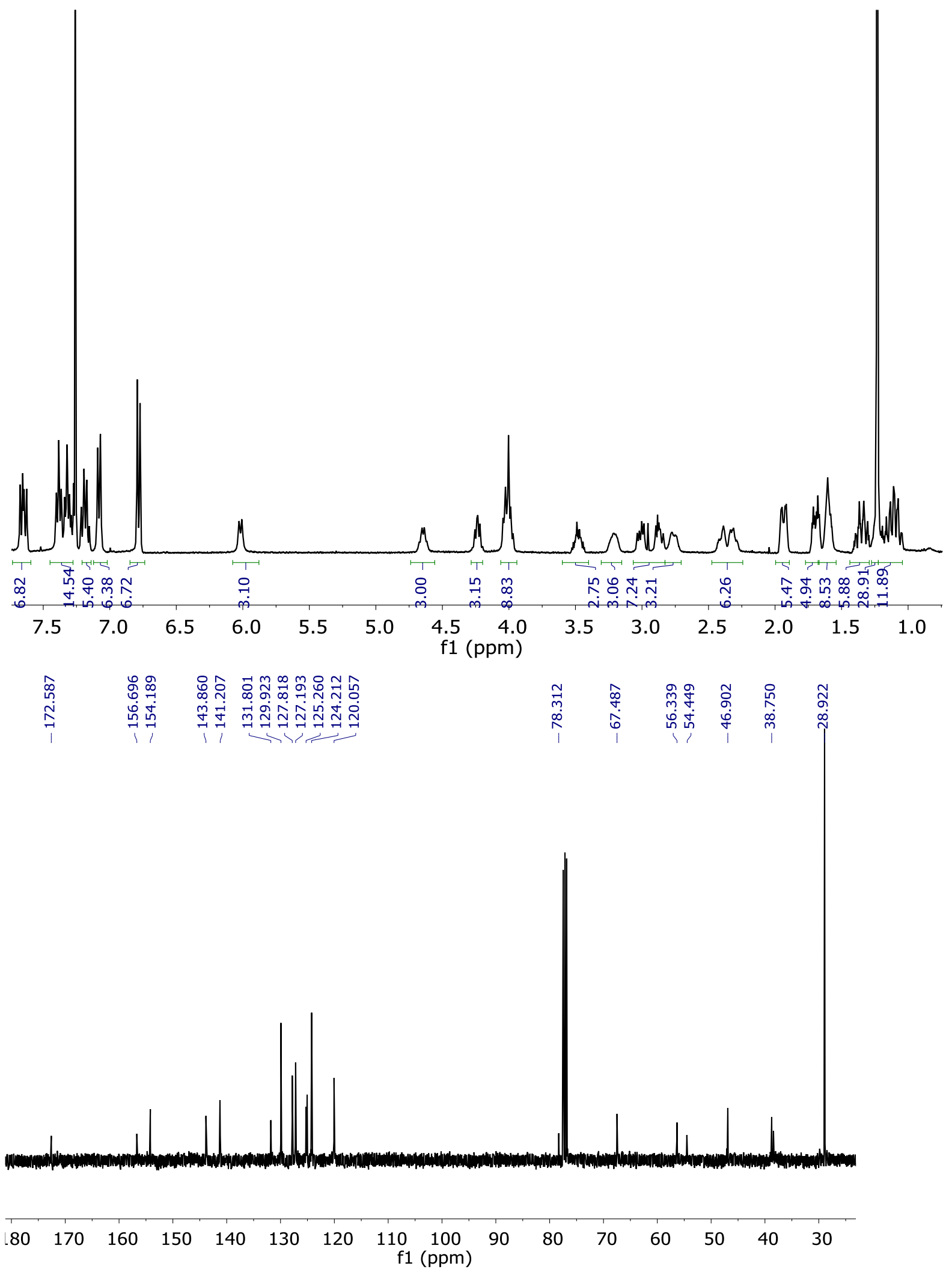

Figure S20. ${ }^{1} \mathrm{H}-\mathrm{NMR}\left(400 \mathrm{MHz}, \mathrm{CD}_{3} \mathrm{Cl}\right)$ and ${ }^{13} \mathrm{C}-\mathrm{NMR}\left(101 \mathrm{MHz}, \mathrm{CD}_{3} \mathrm{Cl}\right)$ spectra of $\mathbf{2 d}$ 


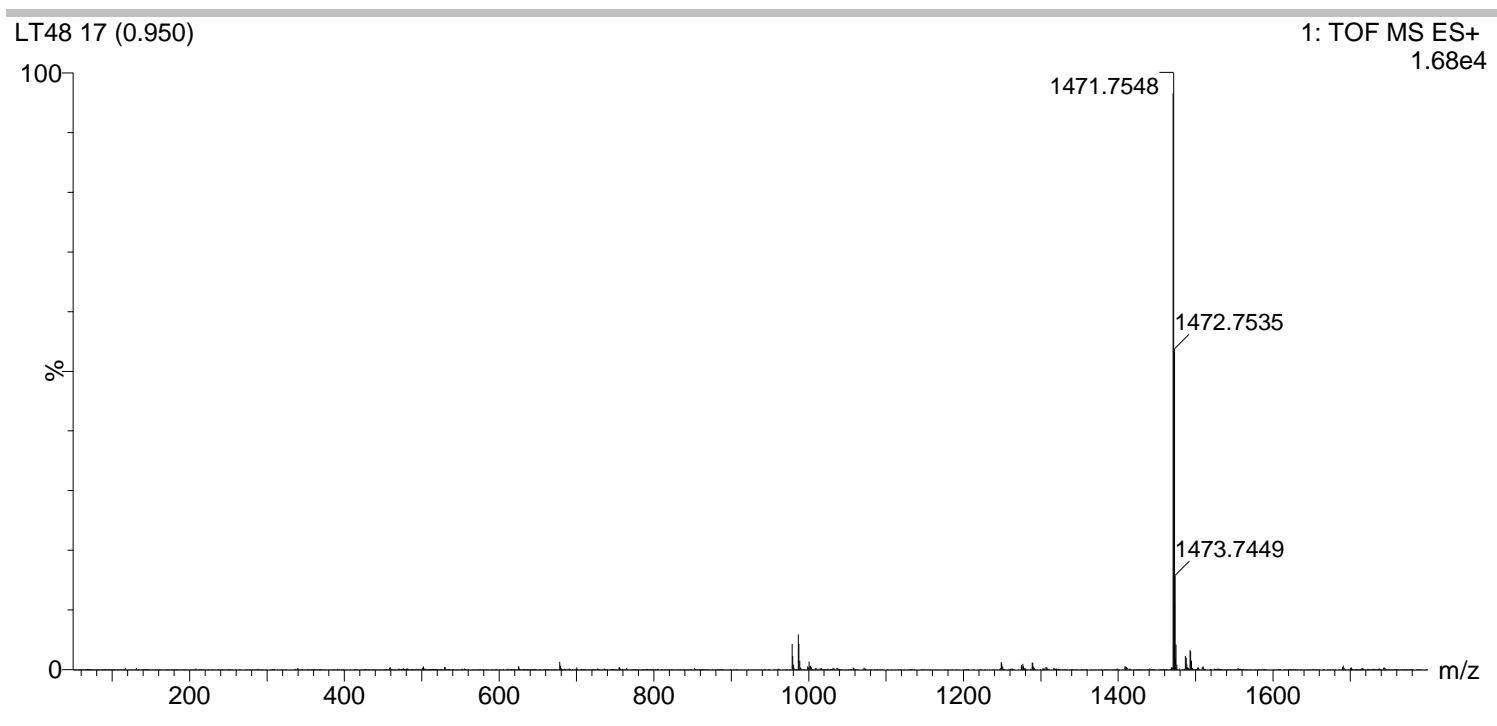

Figure S21. HRMS (ESI+) experimental spectrum of 2d 


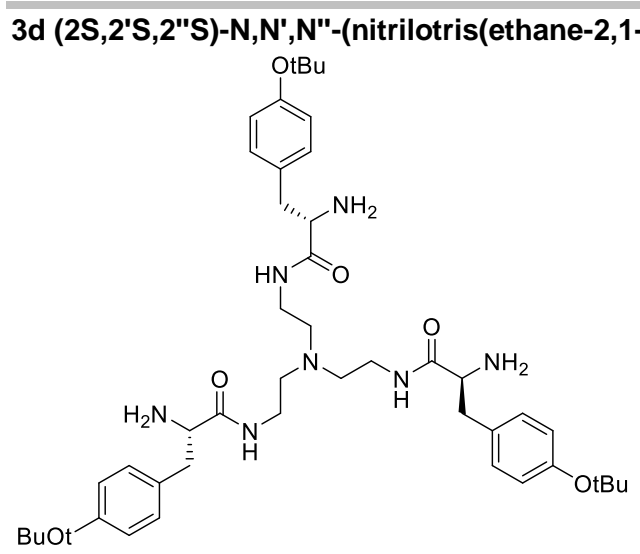

Figure S21. Structure of $\mathbf{3 d}$

2a $(500 \mathrm{mg}, 0.340 \mathrm{mmol})$ was dissolved in $\mathrm{DCM} /$ diethylamine $(1 \mathrm{~mL}, 1: 1)$. The solution was stirred at room temperature for 4 hours when the complete conversion of $\mathbf{2 a}$ was observed by TLC. After that, the solvent was evaporated and the solid was washed several times with hexane giving a $\mathbf{2 b}$ as a white solid $(250 \mathrm{mg}, 0.310 \mathrm{mmol}, 91 \%$ yield)

${ }^{1} \mathrm{H}$ NMR $\left(400 \mathrm{MHz}, \mathrm{CD}_{3} \mathrm{Cl}\right): \delta(\mathrm{ppm})=7.63(\mathrm{t}, J=5.6 \mathrm{~Hz}, 3 \mathrm{H}), 7.12(\mathrm{~m}, 6 \mathrm{H}), 6.90(\mathrm{~m}, 6 \mathrm{H}), 3.54$ (X subsystem from $A B X, J_{A X}=9.3, J_{B X=4.0}$ $\mathrm{Hz}, 3 \mathrm{H}$ ), $3.22(\mathrm{~m}, 6 \mathrm{H}), 3.17$ (B subsystem from $\mathrm{ABX}, J_{B X}=4.0, J_{A B}=3.7 \mathrm{~Hz}, 3 \mathrm{H}$ ), 2.75-2.49 (A subsystem from $A B X, J_{A X}=9.3, J_{A B}=3.7$ $\mathrm{Hz}, 3 \mathrm{H}$ overlapped with $\mathrm{m}, 6 \mathrm{H}), 1.32(\mathrm{~s}, 27 \mathrm{H})$.

${ }^{13} \mathrm{C}$ NMR $\left(101 \mathrm{MHz}, \mathrm{CD}_{3} \mathrm{Cl}\right): \delta(\mathrm{ppm})=173.8,154.3,132.2,129.9,124.4,78.5,56.5,54.3,49.2,40.3,29.0$

HRMS (ESI-TOF) m/z [3d + H]+ Calc.: 804.5382, found: 804.5430

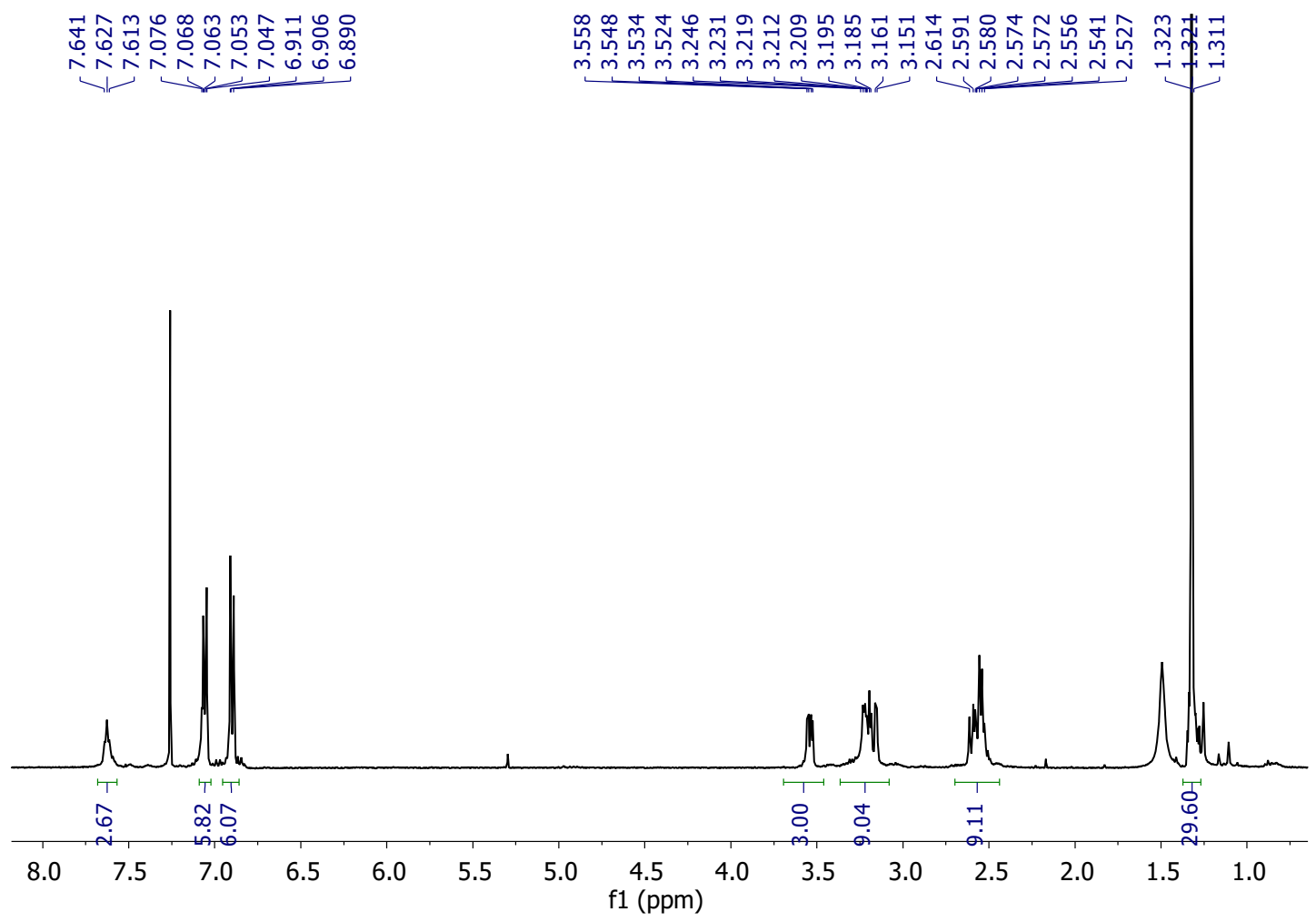




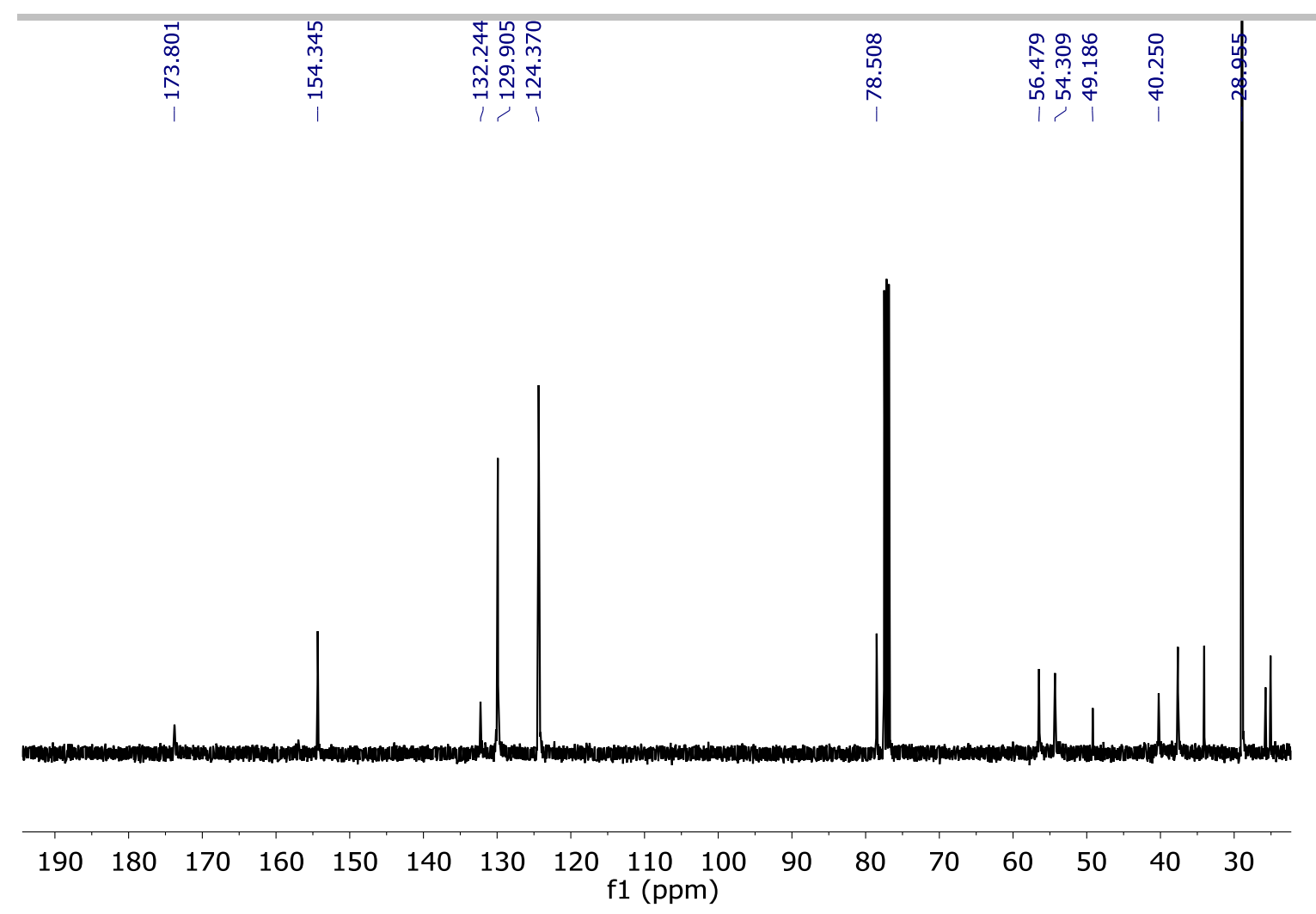

Figure S22. ${ }^{1} \mathrm{H}-\mathrm{NMR}\left(400 \mathrm{MHz}, \mathrm{CD}_{3} \mathrm{Cl}\right)$ and ${ }^{13} \mathrm{C}-\mathrm{NMR}\left(101 \mathrm{MHz}, \mathrm{CD}_{3} \mathrm{Cl}\right)$ spectra of $\mathbf{3 d}$

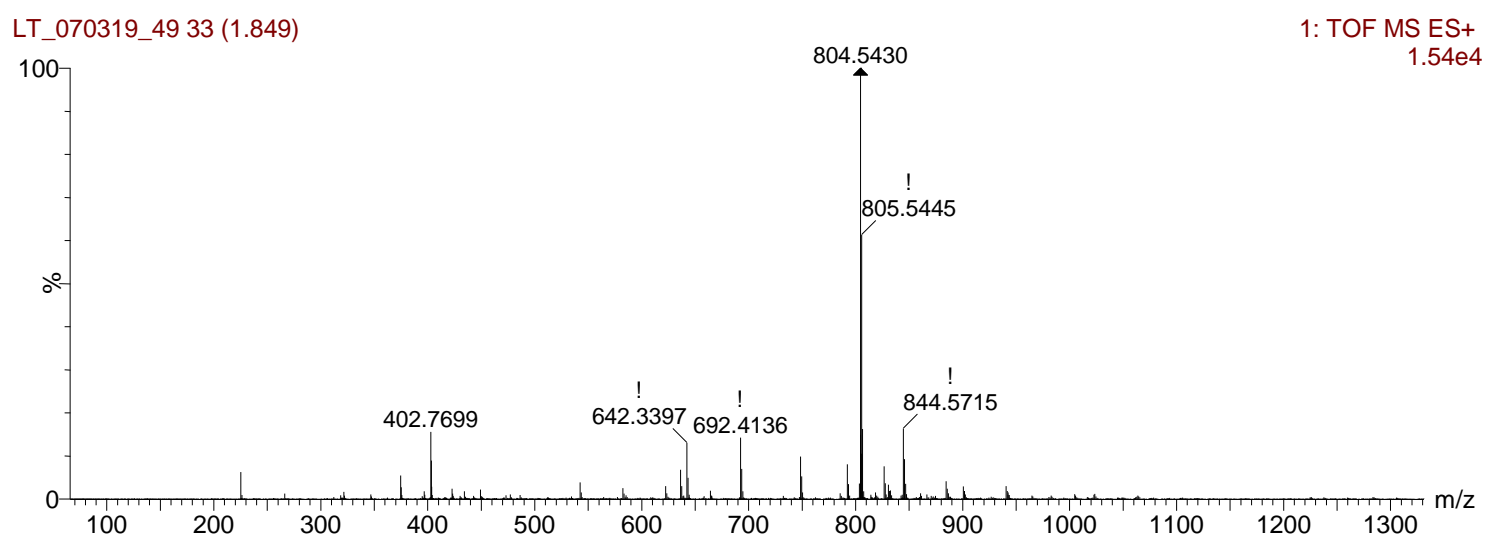

Figure S23. HRMS (ESI+) experimental spectrum of 3d. 


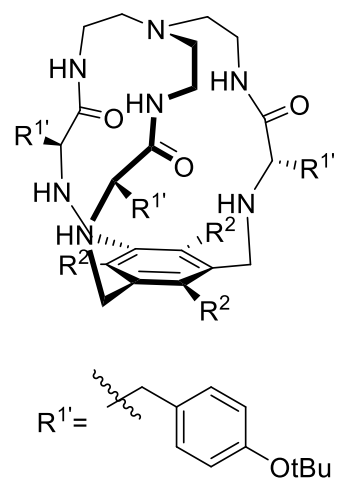

Figure S24. Structure of $\mathbf{4 d}$

2c $(230 \mathrm{mg}, 0.286 \mathrm{mmol})$ was dissolved in $\mathrm{ACN}(50 \mathrm{~mL})$. Tetrabuthylamonium chloride (40 mg, 0.143 mmol), 1,3,5-tris(bromomethyl)2,4,6-trimethylbenzene $(116 \mathrm{mg}, 0.286 \mathrm{mmol})$ and potassium carbonate $(790 \mathrm{mg}, 5.72 \mathrm{mmol})$ were added to the solution. The reaction mixture was refluxed for 16 hours under nitrogen atmosphere. After cooling down to room temperature, the solution was filtered, solvent was evaporated and the resulting crude was purified by flash column chromatography DCM:MeOH $97: 3$ as eluent to give $3 \mathrm{c}$ (90mg, $93.7 \mathrm{mmol}, 33 \%$ yield).

${ }^{1} \mathrm{H}$ NMR $\left(400 \mathrm{MHz}, \mathrm{CD}_{3} \mathrm{Cl}\right): \delta(\mathrm{ppm})=7.21(\mathrm{~d}, J=8.5 \mathrm{~Hz}, 6 \mathrm{H}), 6.97(\mathrm{~d}, J=8.4 \mathrm{~Hz}, 6 \mathrm{H}), 3.68\left(\mathrm{AB}_{\mathrm{q}}, \delta_{\mathrm{A}}=3.72, \delta_{\mathrm{B}}=3.65, J_{A B}=13.6 \mathrm{~Hz}, 6 \mathrm{H}\right)$, 3.43 (X subsystem from $A B X, J_{A X}=4.4, J_{B X}=8.0 \mathrm{~Hz}, 3 \mathrm{H}$ ), 3.28 (A subsystem from $A B X, J_{A X}=4.4, J_{A B}=3.9 \mathrm{~Hz}, 3 \mathrm{H}$ ), 2.94 (B subsystem from $A B X$ overlapped with $3 \mathrm{H}, 6 \mathrm{H}), 2.65(\mathrm{~m}, 6 \mathrm{H}), 2.38(\mathrm{~m}, 3 \mathrm{H}), 2.26(\mathrm{~s}, 9 \mathrm{H}), 1.34(\mathrm{~s}, 27 \mathrm{H})$.

${ }^{13} \mathrm{C}$ NMR $\left(101 \mathrm{MHz}, \mathrm{CDCl}_{3}\right): \delta(\mathrm{ppm})=174.3,154.4,135.2,132.7,130.0,124.6,78.6,63.7,57.9,46.6,41.3,37.9,29.9,29.0,16.2$.

HRMS (ESI-TOF) m/z [4d + H]+ Calc.: 960.6321 , found: 960.7116






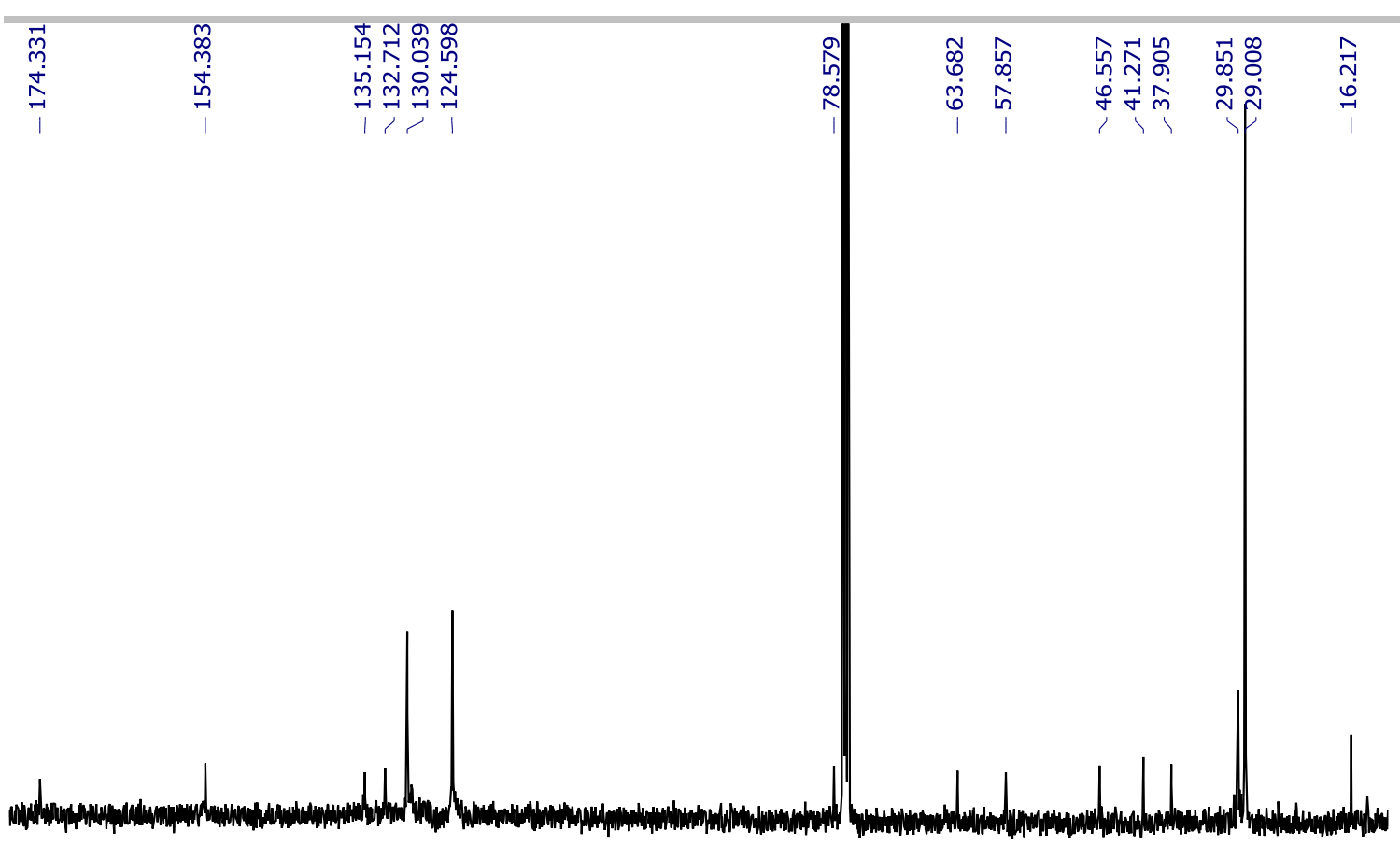

$\begin{array}{lllllllllllllll}170 & 160 & 150 & 140 & 130 & 120 & 110 & \begin{array}{c}100 \\ \mathrm{f} 1(\mathrm{ppm})\end{array} & 80 & 70 & 60 & 50 & 40 & 30 & 20\end{array}$

Figure S25. ${ }^{1} \mathrm{H}-\mathrm{NMR}\left(400 \mathrm{MHz}, \mathrm{CD}_{3} \mathrm{Cl}\right)$ and ${ }^{13} \mathrm{C}-\mathrm{NMR}\left(101 \mathrm{MHz}, \mathrm{CD}_{3} \mathrm{Cl}\right)$ spectra of $4 \mathrm{~d}$

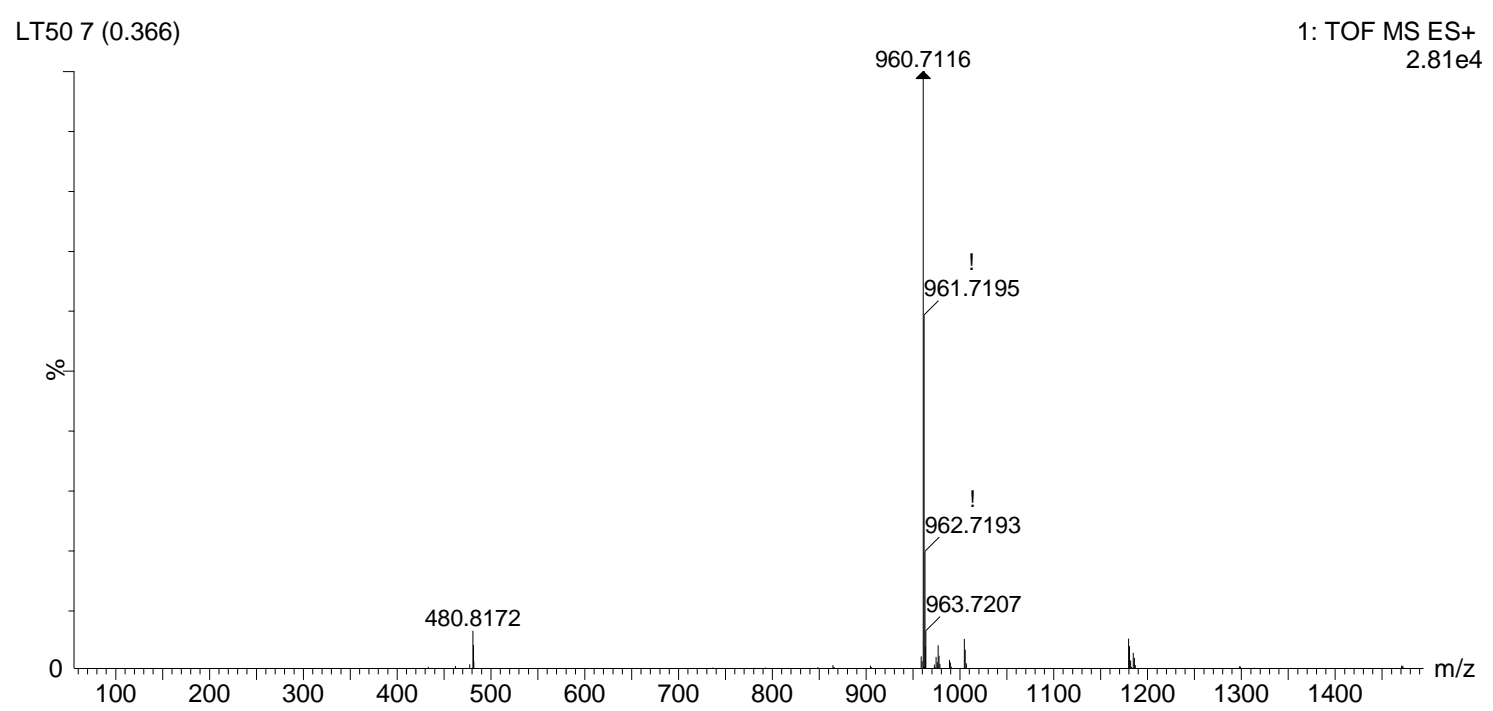

Figure S26. HRMS (ESI+) experimental spectrum of 3d. 

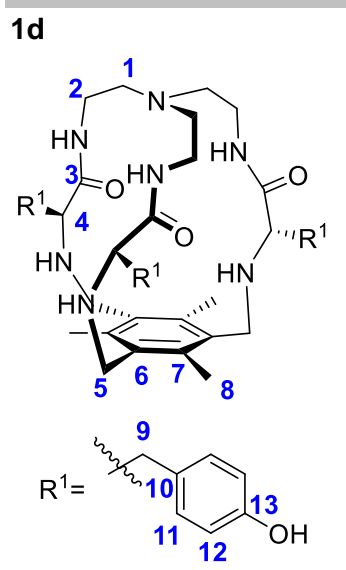

Figure S27. Structure of $\mathbf{1 d}$

4d $(90 \mathrm{mg}, 93.7 \mathrm{mmol})$ was dissolved in DCM $(1.5 \mathrm{ml})$. Triethylsilylsilane $(0.15 \mathrm{~mL}, 1.1 \mathrm{mmol})$ and trifluoroacetic acid $(1 \mathrm{~mL})$ were added. The solution was stirred at room temperature during 3 hours and then solvents were evaporated under an air current affording a yellow oil. The residue was washed several times with diethyl ether and purified through reverse phase flash chromatography affording 1d.4TFA as a white solid (108 mg, $86 \mathrm{mmol}, 91 \%$ yield).TFA 4d.4FTA was dissolved in methanol and amberlite IRA-95 resin was added while stirring until neutral to basic $\mathrm{pH}$ was reached. Finally, amberlite was filtered off and the solvent was evaporated to obtain 1d (43 mg, $34 \mathrm{mmol}, 77 \%$ overall yield).

${ }^{1} \mathrm{H}$ NMR $\left(400 \mathrm{MHz}, \mathrm{CD}_{3} \mathrm{OD}\right): \delta(\mathrm{ppm})=7.09(\mathrm{~d}, J=8.2 \mathrm{~Hz}, 2 \mathrm{H}, \mathrm{H} 11), 6.72(\mathrm{~d}, J=8.1 \mathrm{~Hz}, 2 \mathrm{H}, \mathrm{H} 12), 3.78\left(\mathrm{AB}, \delta_{\mathrm{A}}=3.82, \delta_{\mathrm{B}}=3.74, J_{A B}=14\right.$ $\mathrm{Hz}, 6 \mathrm{H}, \mathrm{H5}$ ), 3.40 (X subsystem from $\mathrm{ABX}, J_{A X}=6.2, J_{B X}=6.6 \mathrm{~Hz}, 3 \mathrm{H}, \mathrm{H} 4$ ), 3.02 (A subsystem from $\mathrm{ABX}, J_{A X}=6.2, J_{A B}=3.7 \mathrm{~Hz}, 3 \mathrm{H}, \mathrm{H} 9$ ) 2.93 (B subsystem from $\left.A B X, J_{B X}=6.6 J_{A B}=3.7 \mathrm{~Hz}, 3 \mathrm{H}, \mathrm{H} 9\right), 2.0(\mathrm{~m}, 6 \mathrm{H}, \mathrm{H} 2), 2.37(\mathrm{~m}, 6 \mathrm{H}, \mathrm{H} 1), 2.27(\mathrm{~s}, 9 \mathrm{H}, \mathrm{H} 8)$.

${ }^{13} \mathrm{C} \mathrm{NMR}\left(100 \mathrm{MHz}, \mathrm{CD}_{3} \mathrm{OD}\right): \delta(\mathrm{ppm})=174.7$ (C3), 155.2 (C13), 135.9 (C7), 130.2 (C11), 128.2 (C6), 114.9 (C12), 62.5 (C4), 56.7 (C1), 45.6 (C5), 40.7 (C2), 37.1 (C9), 15.3 (C8).

HRMS (ESI-TOF) m/z [1d + H]+ Calc.: 792.443, found: 792.4522

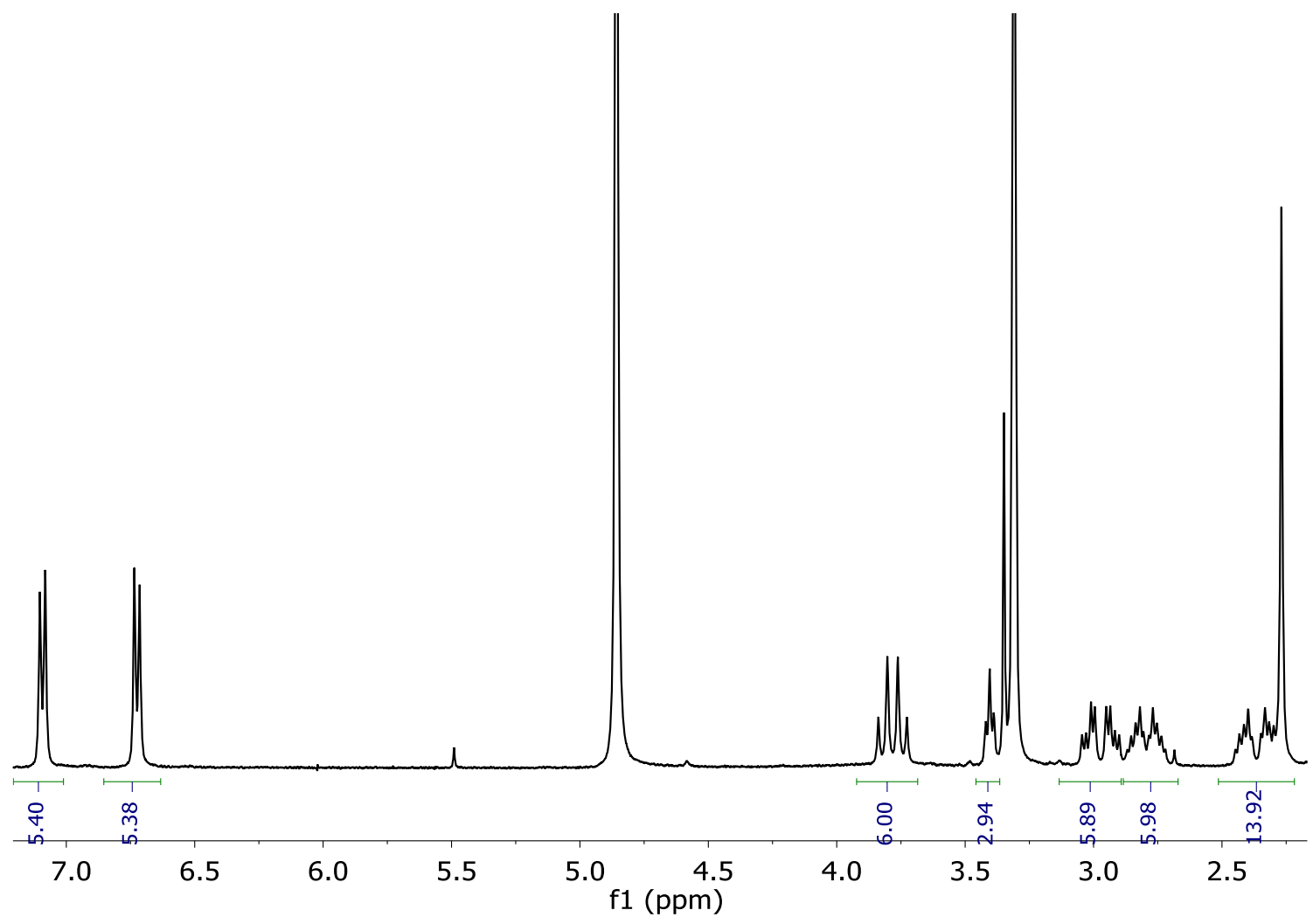




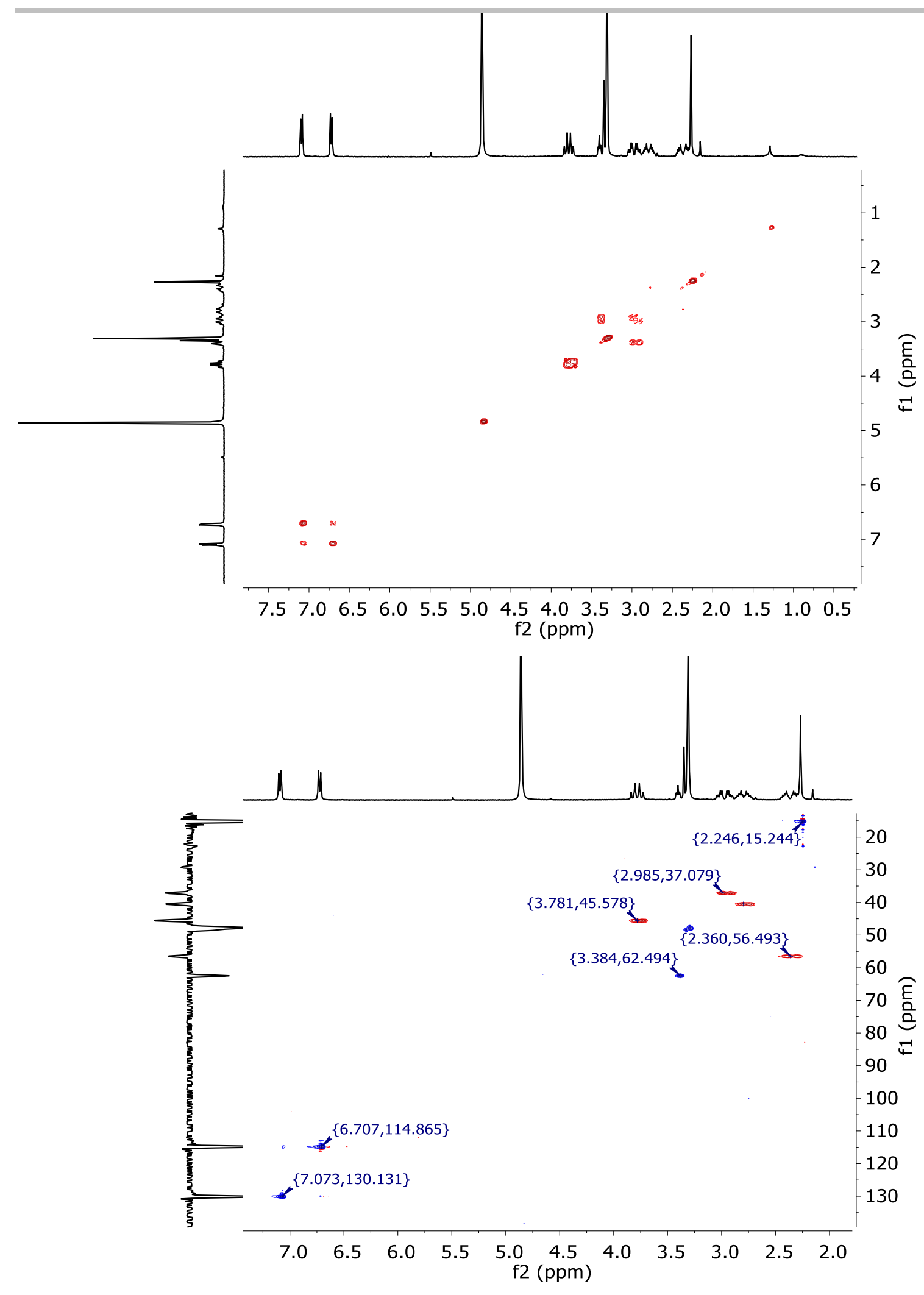




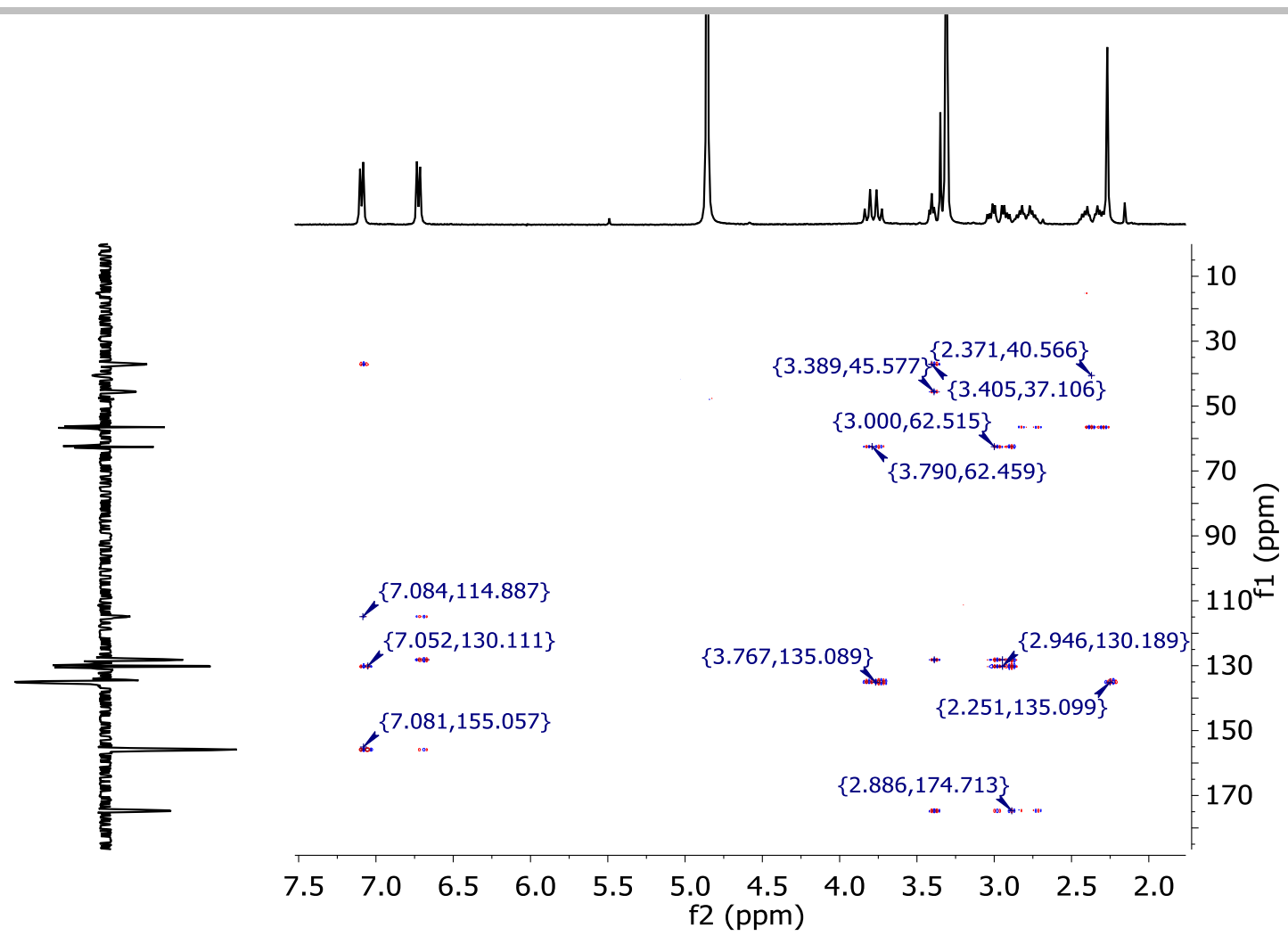

Figure S28. ${ }^{1} \mathrm{H}-\mathrm{NMR}\left(400 \mathrm{MHz}, \mathrm{CD}_{3} \mathrm{OD}\right), \mathrm{COSY}, \mathrm{HSQC}$ and $\mathrm{HMBC}$ spectra of $1 \mathrm{c}$.

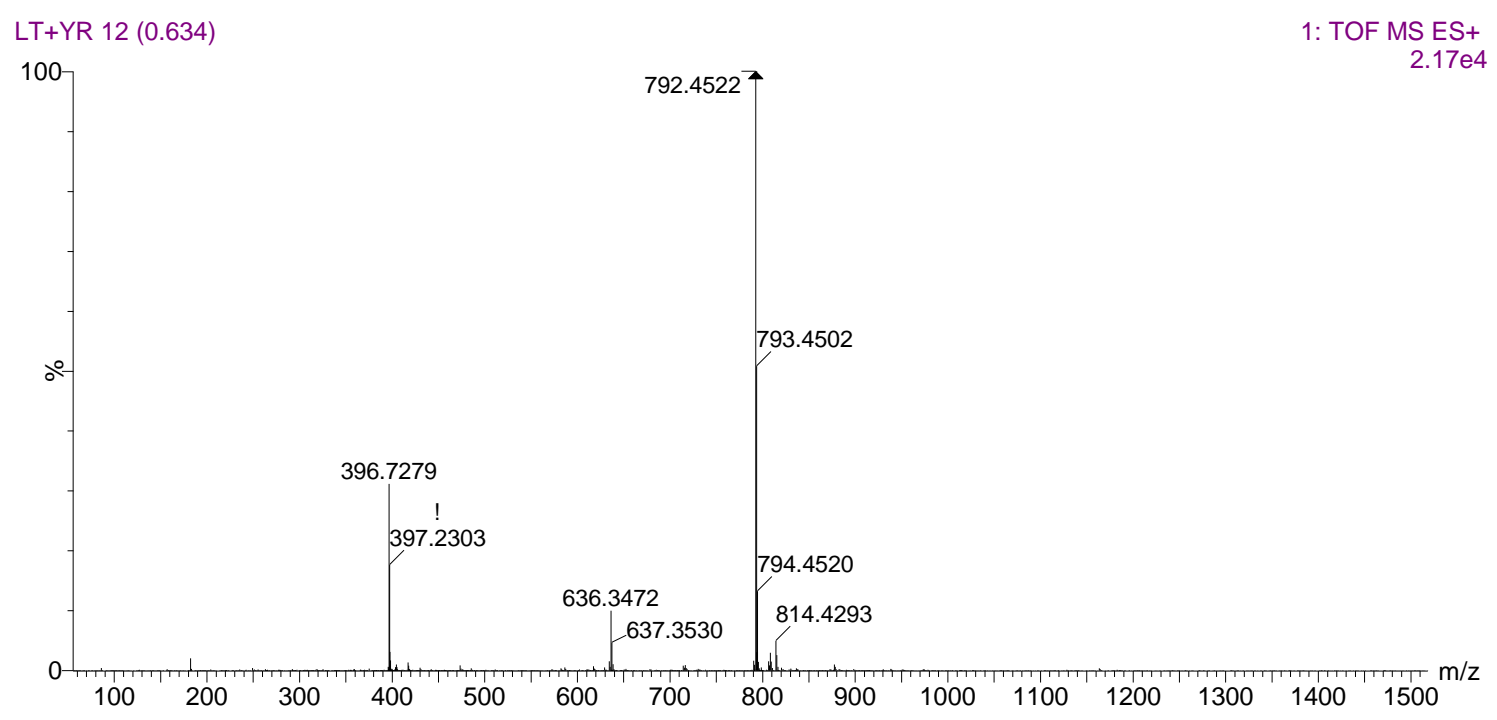

Figure S29. HRMS (ESI+) experimental spectrum of 1c. 


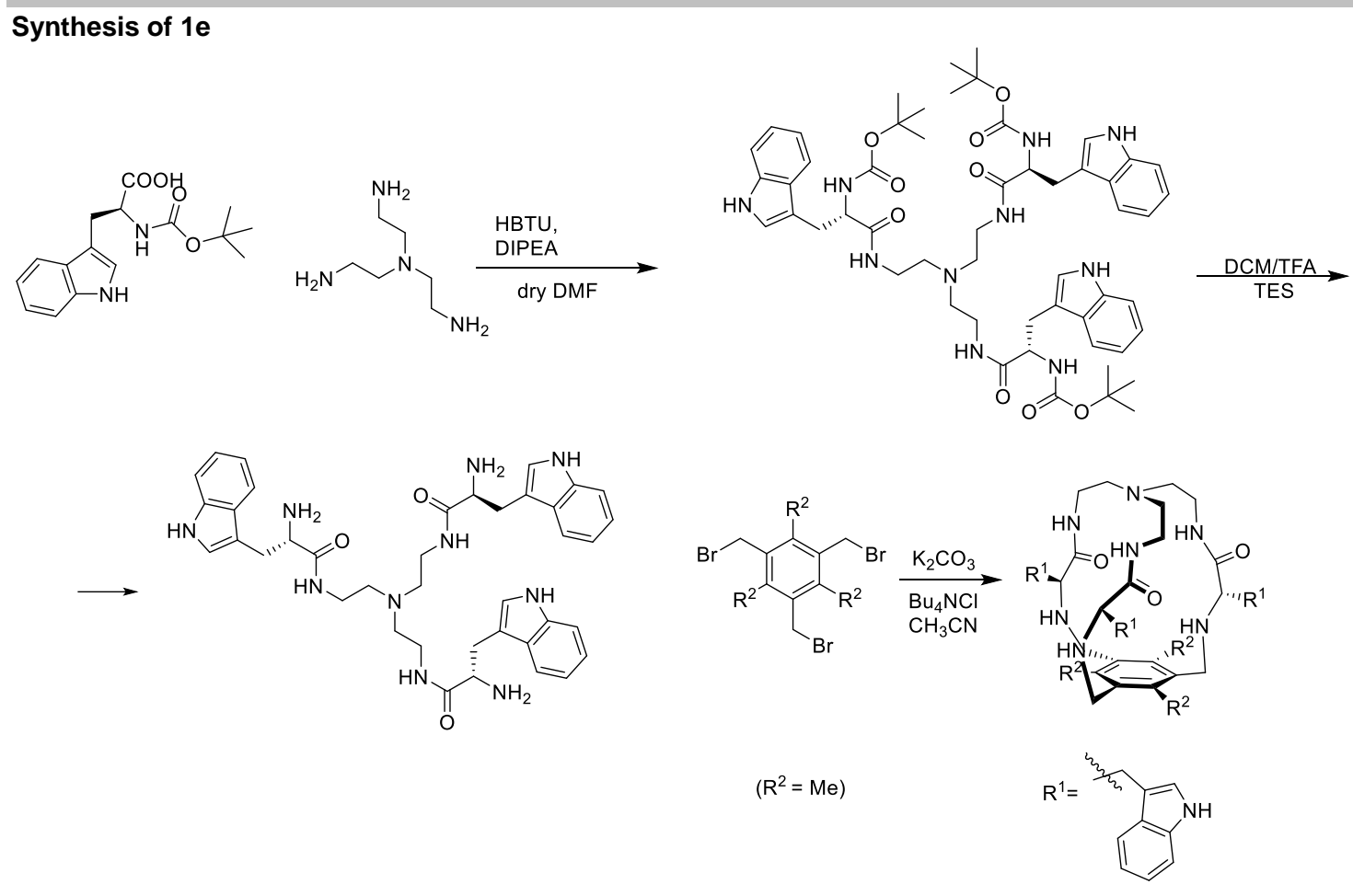

Scheme S4. Full synthetic scheme of $1 e$

2e tri-tert-butyl ((2S,2'S,2"S)-((nitrilotris(ethane-2,1-diyl))tris(azanediyl))tris(3-(1H-indol-3-yl)-1-oxopropane-1,2-diyl))tricarbamate<smiles>CC(C)(C)OC(=O)N[C@@H](Cc1c[nH]c2ccccc12)C(=O)NCCN(CCNC(=O)[C@H](Cc1c[nH]c2ccccc12)NC(=O)OC(C)(C)C)CCNC(=O)[C@H](Cc1c[nH]c2ccccc12)NC(=O)OC(C)(C)C</smiles>

Figure S30. Structure of $2 \mathrm{E}$

Boc-Trp-OH (300 mg, $0.99 \mathrm{mmol})$ was dissolved in dry DCM $(5 \mathrm{~mL})$ and DMF $(0.4 \mathrm{~mL})$. (2-(1H-benzotriazol-1-yl)-1,1,3,3tetramethyluronium hexafluorophosphate (HBTU $0.375 \mathrm{mg}, 0.989 \mathrm{mmol}$ ) $\mathrm{N}, \mathrm{N}$-diisopropylethylamine (DIPEA, $0.09 \mathrm{~mL}, 0.99 \mathrm{mmol}$ ) and tris(2-aminoethyl)amine $(0.041 \mathrm{~mL}, 0.30 \mathrm{mmol})$ were added over the solution. The solution was stirred at room temperature for 16 hours, after no more conversion of the starting material was observed by TLC. The mixture was diluted with more DCM and washed with water $(3 \times 10 \mathrm{~mL})$. Combined organic fractions were washed with aqueous $\mathrm{LiCl}(5 \% \mathrm{w} / \mathrm{w})$, dried over $\mathrm{MgSO}_{4}$ and concentrated to dryness. The residue was purified by flash chromatography using DCM:MeOH 95:5 to give $0.276 \mathrm{mg}$ of $\mathbf{2 e}(0.275 \mathrm{mmol}, 92 \%$ yield).

${ }^{1} \mathrm{H}$ NMR $\left(400 \mathrm{MHz}, \mathrm{CD}_{3} \mathrm{Cl}\right): \delta(\mathrm{ppm})=8.78(\mathrm{~s}, 3 \mathrm{H}), 7.54(\mathrm{~d}, J=7.9 \mathrm{~Hz}, 3 \mathrm{H}), 7.27$ (d, J=8.1 Hz, 3H), 7.10 (t, J=7.5 Hz, 3H), 7.01 (t, J=7.5 $\mathrm{Hz}, 6 \mathrm{H}), 6.97(\mathrm{~s}, 3 \mathrm{H}), 6.41(\mathrm{~s}, 3 \mathrm{H}), 5.54(\mathrm{~s}, 3 \mathrm{H}), 4.39$ (X subsystem from $\left.\mathrm{ABX} J_{A X}=8, J_{B X}=6 \mathrm{~Hz}, 3 \mathrm{H}\right), 3.30-3.03$ ( $\mathrm{m}, \mathrm{A}$ and $\mathrm{B}$ subsystems from $\left.A B X, J_{A X}=8.0, J_{B X}=5.7, J_{A B}=4.4 \mathrm{~Hz}, 6 \mathrm{H}\right), 2.74(\mathrm{~m}, 6 \mathrm{H}), 2.43(\mathrm{~m}, 6 \mathrm{H}), 1.41(\mathrm{~s}, 27 \mathrm{H})$.

${ }^{13} \mathrm{C}$ NMR $\left(100 \mathrm{MHz}, \mathrm{CD}_{3} \mathrm{Cl}\right): \delta(\mathrm{ppm})=172.5,156.0,136.2,127.7,123,7,121.9,119.4,118.9,111.4,80.3,55.9,53.5,53.0,28.9,28.4$.

HRMS (ESI-TOF) m/z [2e + H] Calc: 1005.5310, found: 1005.6048 

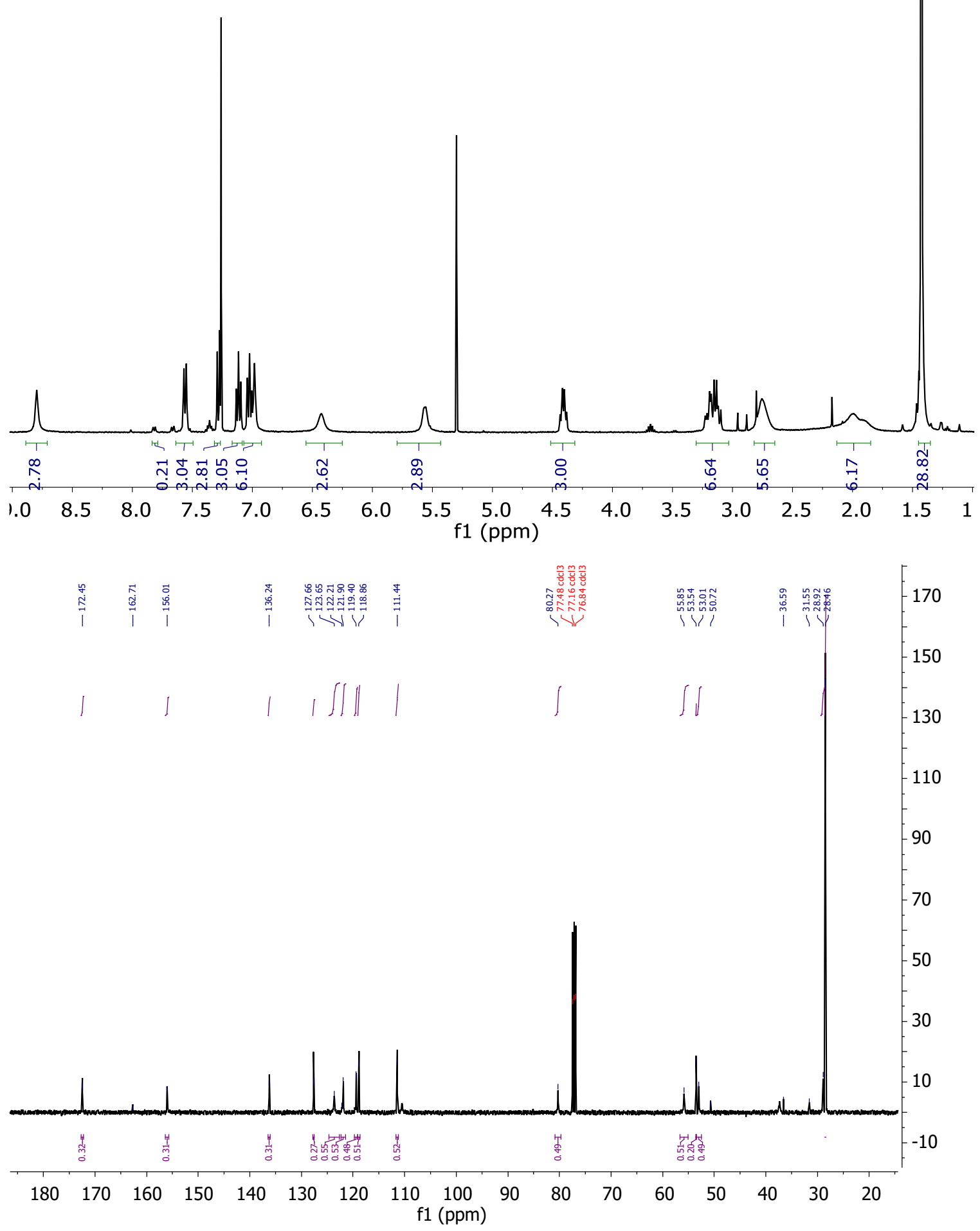

Figure S31. ${ }^{1} \mathrm{H}-\mathrm{NMR}\left(400 \mathrm{MHz}, \mathrm{CD}_{3} \mathrm{Cl}\right)$, and ${ }^{13} \mathrm{C}-\mathrm{NMR}\left(101 \mathrm{MHz}, \mathrm{CD}_{3} \mathrm{Cl}\right)$ spectra of $2 \mathrm{e}$ 


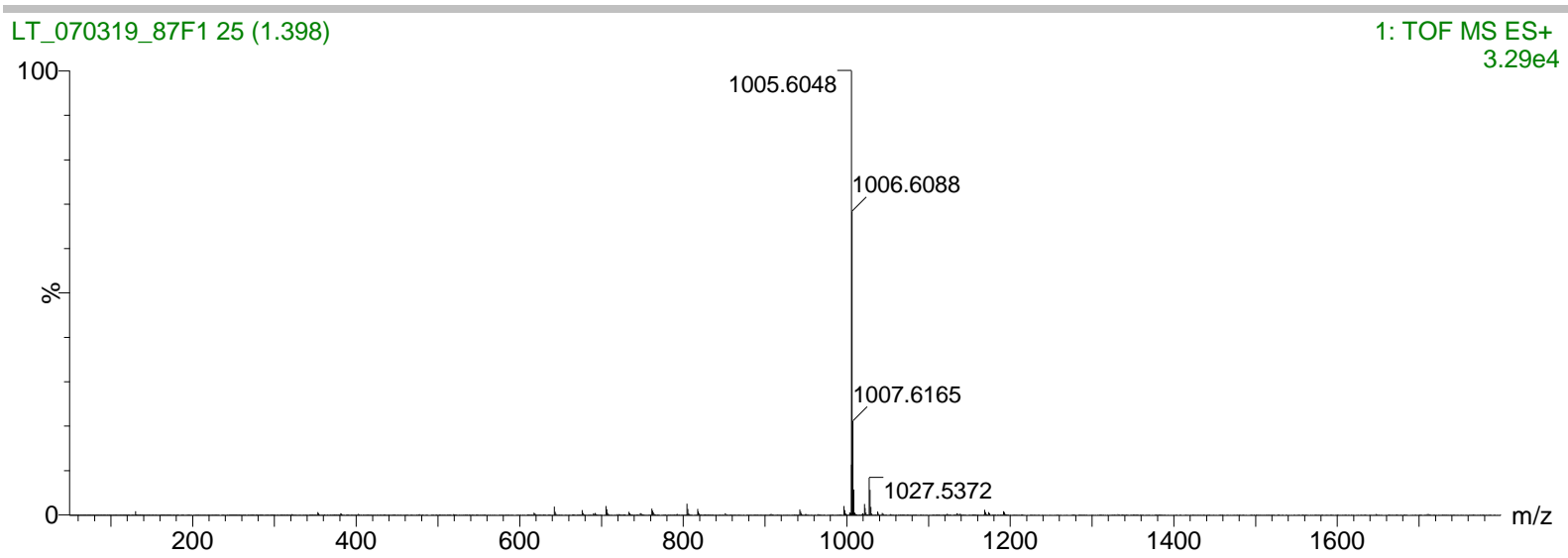

Figure S32. HRMS (ESI+) experimental spectrum of $2 \mathbf{e}$ 
<smiles>N[C@@H](Cc1c[nH]c2ccccc12)C(=O)NCCN(CCNC(=O)[C@H](N)Cc1c[nH]c2ccccc12)CCNC(=O)[C@H](N)Cc1c[nH]c2ccccc12</smiles>

Figure S33. Structure of $3 e$

2e $(250 \mathrm{mg}, 0.249 \mathrm{mmol})$ was dissolved in DCM $(1.5 \mathrm{ml})$. Triethylsilylsilane $(0.44 \mathrm{~mL}, 3.73 \mathrm{mmol})$ and trifluoroacetic acid $(1 \mathrm{~mL})$ were added. The solution was stirred at room temperature during 3 hours and then solvents were evaporated under an air current aff ording a yellow oil. It was washed several times with diethyl ether and dried affording $\mathbf{3 . 4 T F A}$ as a white solid $(253 \mathrm{mg}, 0.299 \mathrm{mmol}, 88 \%$ yield).

${ }^{1} \mathrm{H}$ NMR $\left(400 \mathrm{MHz}, \mathrm{CD}_{3} \mathrm{OD}\right): \delta(\mathrm{ppm})=7.59(\mathrm{~d}, \mathrm{~J}=7.8 \mathrm{~Hz}, 3 \mathrm{H}), 7.39(\mathrm{~d}, \mathrm{~J}=8.1 \mathrm{~Hz}, 3 \mathrm{H}), 7.21(\mathrm{~s}, 3 \mathrm{H}), 7.14(\mathrm{t}, \mathrm{J}=7.5 \mathrm{~Hz}, 3 \mathrm{H}), 7.06(\mathrm{t}, \mathrm{J}=7.4$, $3 \mathrm{H}$ ), 4.10 (X subsystem from $A B X, J_{A X}=7.4, J_{B X}=7.4 \mathrm{~Hz}, 3 \mathrm{H}$ ), 3.41-3.33 (A and B subsystems from $A B X, J_{A X}=7.4, J_{B X}=7.4 J_{A B}=4.5 \mathrm{~Hz}$ overlapped with 6 additional $\mathrm{H}, 12 \mathrm{H}), 3.35(\mathrm{~m}, 6 \mathrm{H}), 2.73(\mathrm{~m}, 6 \mathrm{H})$.

${ }^{13} \mathrm{C}$ NMR (101 MHz, CD $\left.{ }_{3} \mathrm{OD}\right): \delta(\mathrm{ppm})=199.3,166.3,156.5,153.8,151.1,148.5,147.3,140.9,136.2,83.4,81.5,63.9,56$.

HRMS (ESI-TOF) m/z [3e + H] Calc.: 705.3911, found: 705.4070

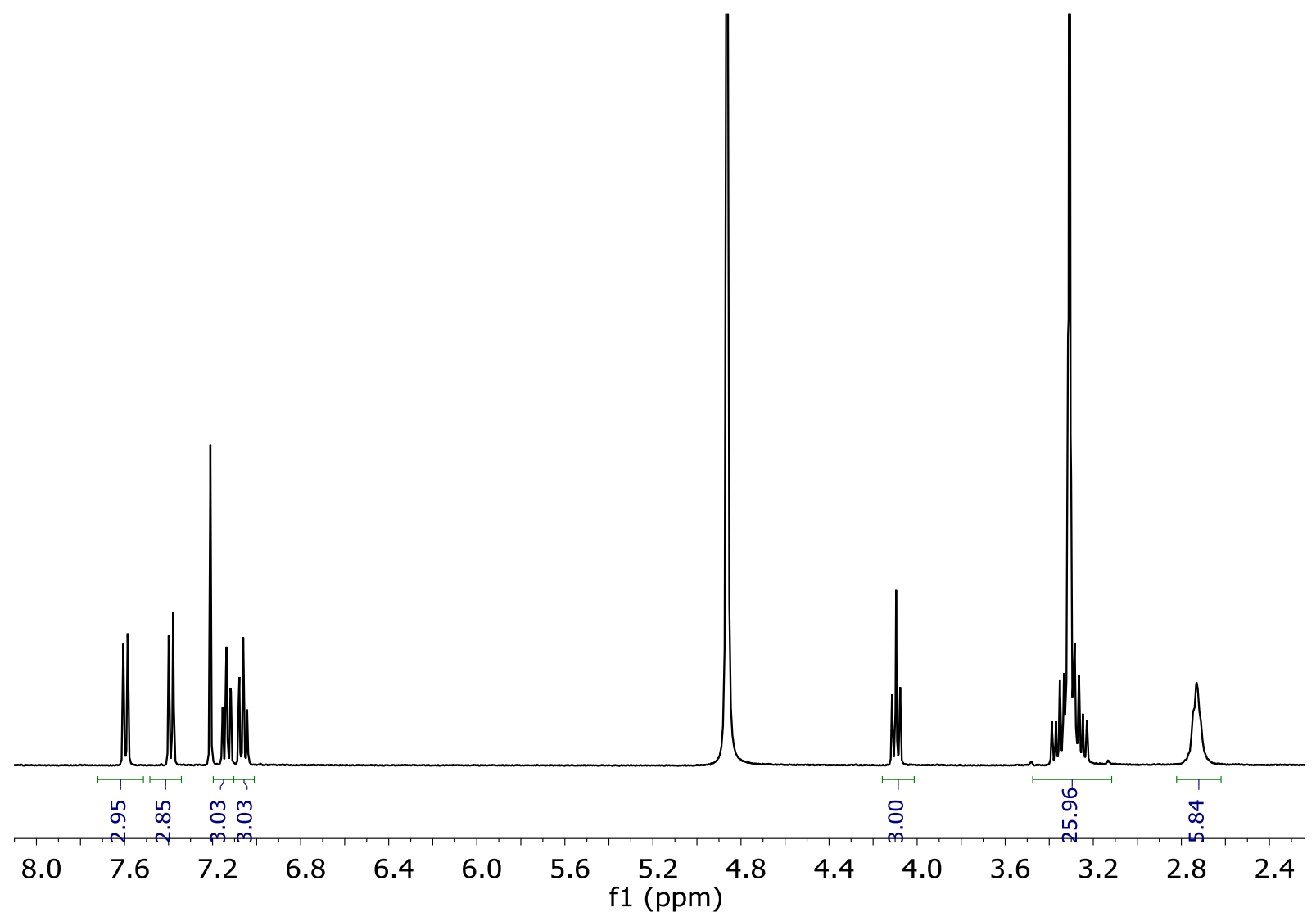




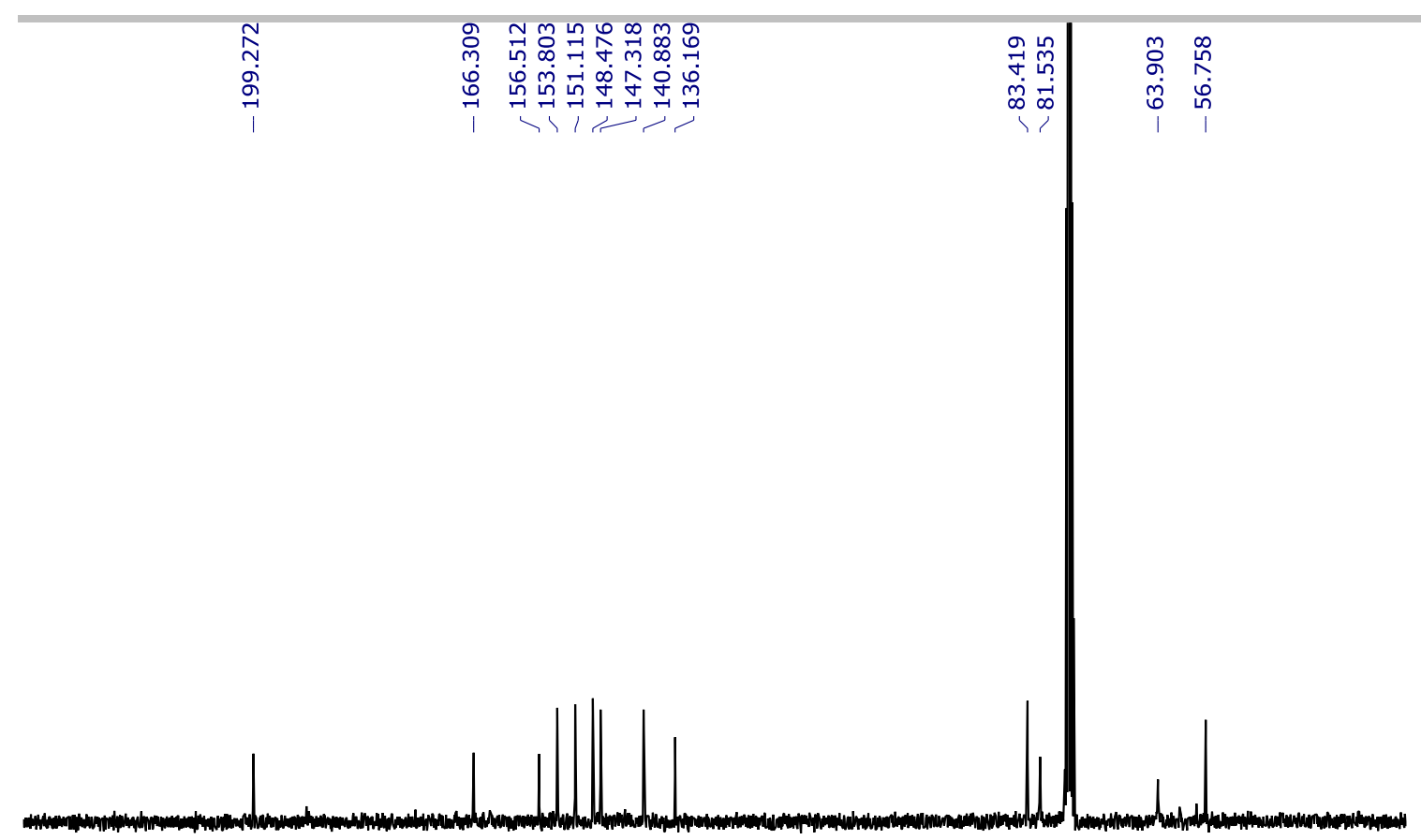

$\begin{array}{lllllllllllllllllllll}230 & 220 & 210 & 200 & 190 & 180 & 170 & 160 & 150 & 140 & 130 & 120 & 110 & 100 & 90 & 80 & 70 & 60 & 50 & 40 & 30\end{array}$ f1 (ppm)

Figure S34. ${ }^{\mathrm{H}} \mathrm{H}-\mathrm{NMR}\left(400 \mathrm{MHz} \mathrm{CD}_{3} \mathrm{OD}\right)$ and ${ }^{13} \mathrm{C}-\mathrm{NMR}\left(101 \mathrm{MHz}, \mathrm{CD}_{3} \mathrm{Cl}\right)$ spectra of $3 \mathbf{e}$

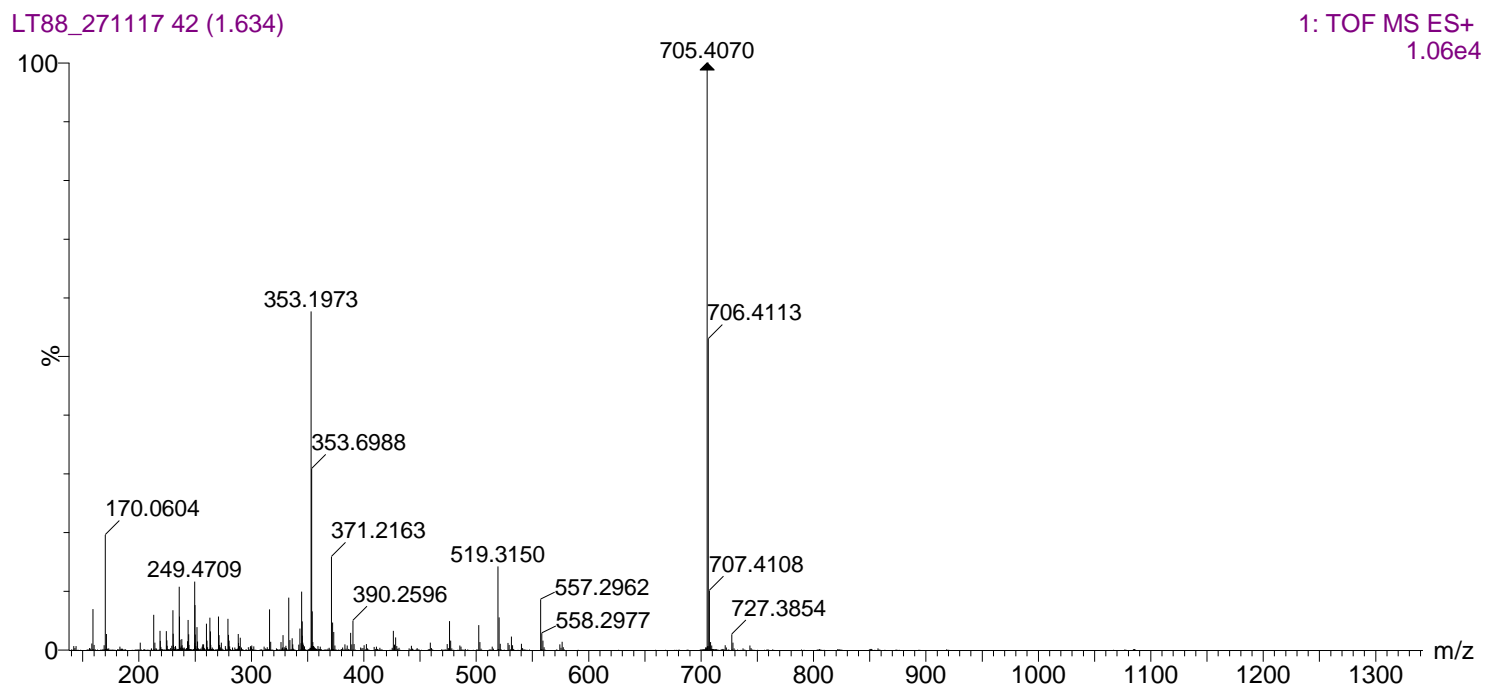

Figure S35. HRMS (ESI+) experimental spectrum of 3e 


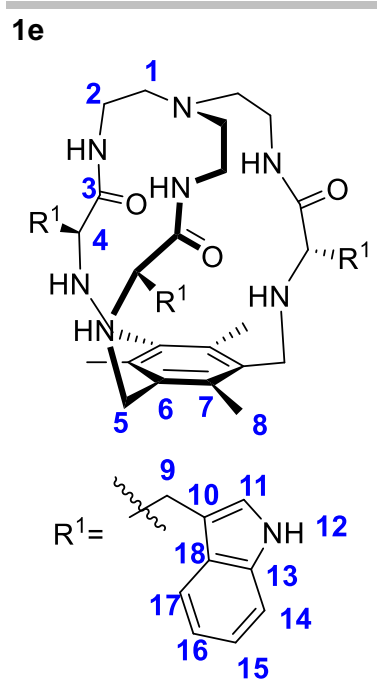

Figure S36. Structure of $1 \mathrm{e}$

3 e $(150 \mathrm{mg}, 0.213 \mathrm{mmol})$ was dissolved in dry acetonitrile $(40 \mathrm{~mL}) . \mathrm{Bu}_{4} \mathrm{Cl}(29 \mathrm{mg}, 0.106 \mathrm{mmol})$ and $\mathrm{K}_{2} \mathrm{CO}_{3}(588 \mathrm{mg}, 4.25 \mathrm{mmol})$ were then added. 1,3,5-tris(bromomethyl)-2,4,6-trimethylbenzene $(93.8 \mathrm{mg}, 0.212 \mathrm{mmol}$ ) was dissolved in acetonitrile $(10 \mathrm{~mL})$ and the solution was added to the $3 \mathrm{e}$ solution. The reaction mixture refluxed for 16 hours. Solvent was evaporated and the resulting crude was purified by flash chromatography using DCM:MeOH 95:5 as eluent to give 1e as a white solid (64 mg, $57.7 \mathrm{mmol}, 33 \%$ yield).

${ }^{1} \mathrm{H}$ NMR $\left(400 \mathrm{MHz}, \mathrm{CD}_{3} \mathrm{Cl}\right): \delta(\mathrm{ppm})=8.22(\mathrm{~s}, 3 \mathrm{H}, \mathrm{H} 12), 7.66$ (d, J=7.8 Hz, 3H, H17), 7.33 (d, J=8.0 Hz, 3H, H14), 7.26 (s, 3H, H11), $7.10(\mathrm{~m}, 9 \mathrm{H}, \mathrm{H} 15, \mathrm{H} 16), 6.18\left(\mathrm{~s}, 3 \mathrm{H}, \mathrm{NH}_{\text {amide }}\right), 3.99\left(\mathrm{AB}_{\mathrm{q}}, \delta_{\mathrm{A}}=4.02, \delta_{\mathrm{B}}=3.94, \mathrm{~J}_{\mathrm{AB}}=14 \mathrm{~Hz}, 6 \mathrm{H}, \mathrm{H} 5\right), 3.40(\mathrm{~m}, 3 \mathrm{H}, \mathrm{H} 4), 3.21(\mathrm{~m}, 6 \mathrm{H}, \mathrm{H} 9)$, $2.46(\mathrm{~m}, 3 \mathrm{H}, \mathrm{H} 2), 2.41$ (s, 9H, H8), 2.06 ( $\mathrm{m}, 6 \mathrm{H}, \mathrm{H} 2$ and $\left.\mathrm{NH}_{\mathrm{amine}}\right), 1.63(\mathrm{~m}, 6 \mathrm{H}, \mathrm{H} 1)$.

${ }^{13} \mathrm{C}$ NMR (101 MHz, CD 3 OD): $\delta(\mathrm{ppm})=176.0$ (C3), 140.0 (C7), 136.6 (C10), 135.5 (C6), 127.9 (C7), 123.8 (C15/16), 122.0 (C15/16), 119.3 (C11), 118.7 (C17), 111.7 (C14), 110.2 (C13), 61.8 (C4), 56.3 (C1), 45.9 (C5), 40.2 (C2), 27.8 (C9), 16.3 (C8).

HRMS (ESI-TOF) m/z [1e + H] Calc.: 861.485 , found: 861.5199

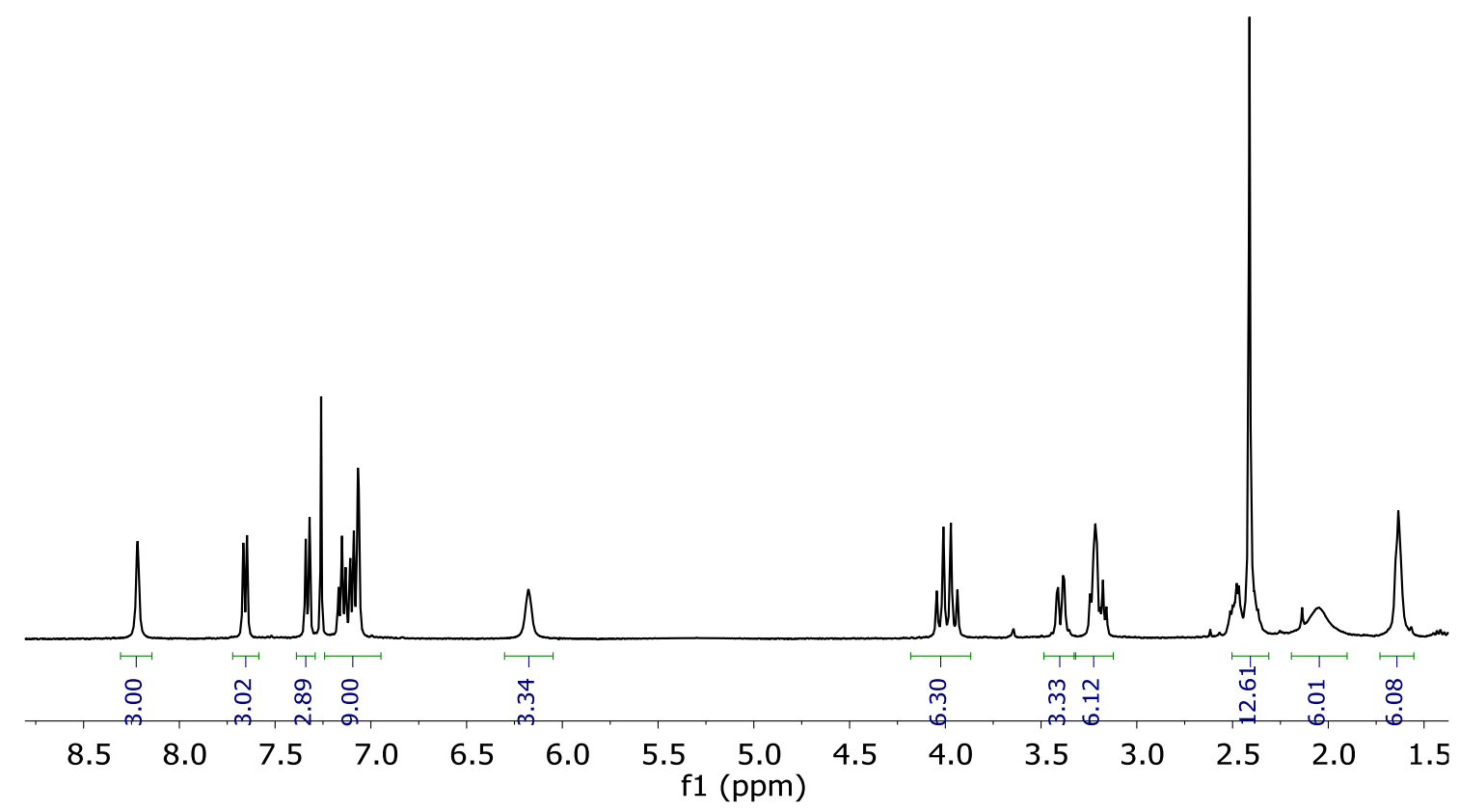




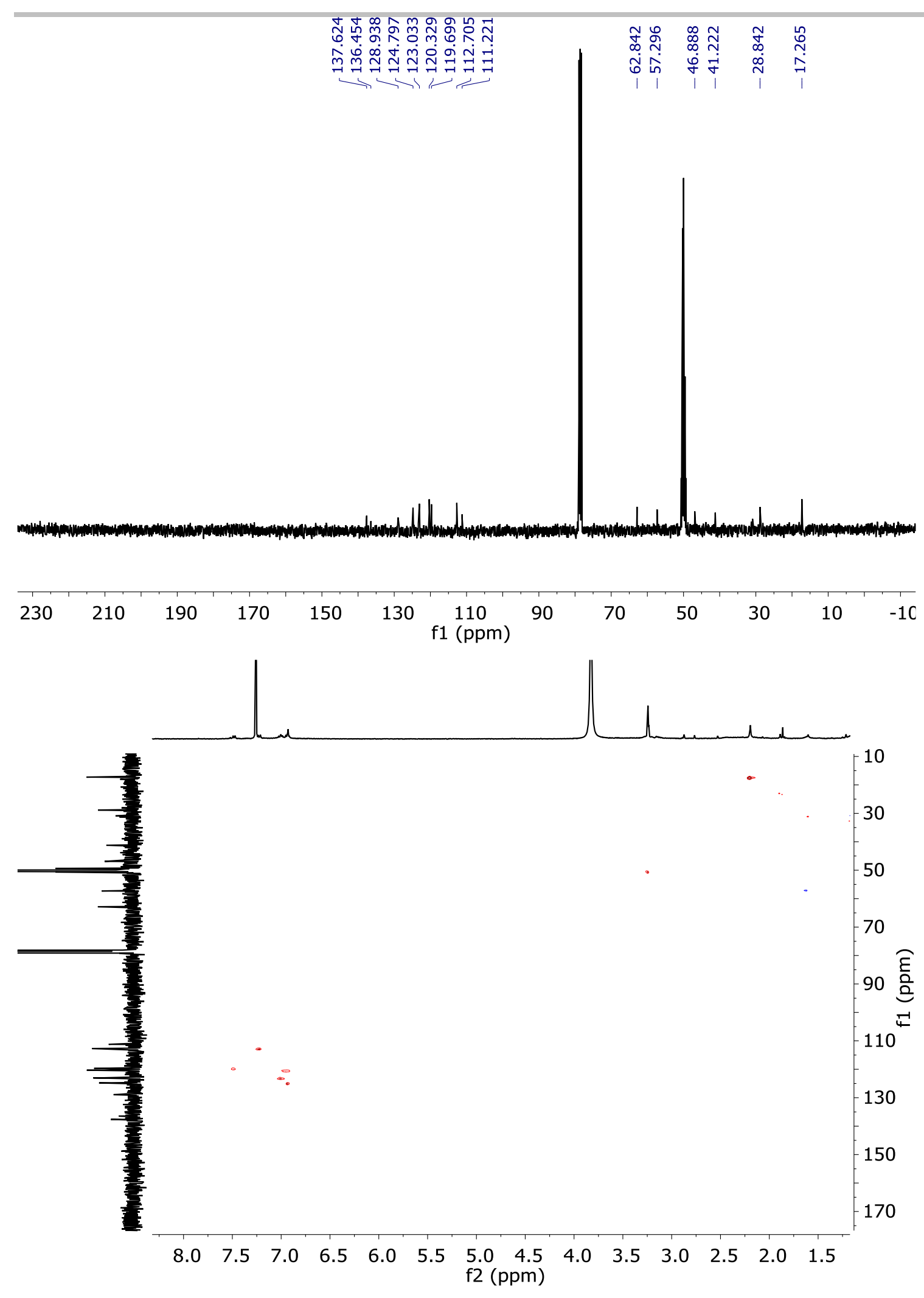




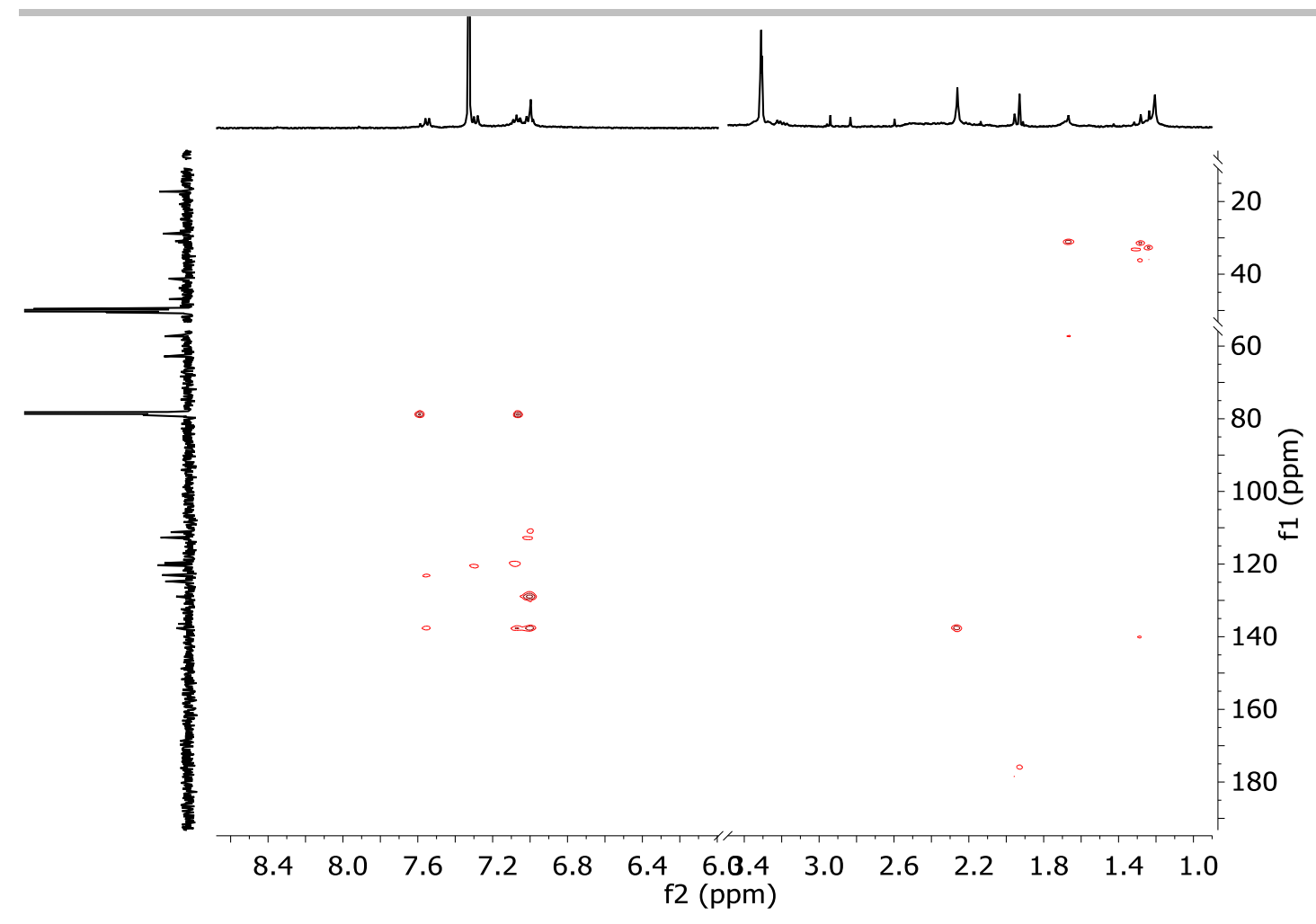

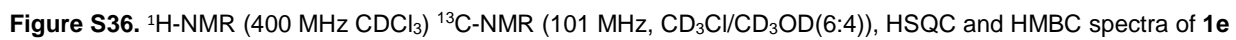

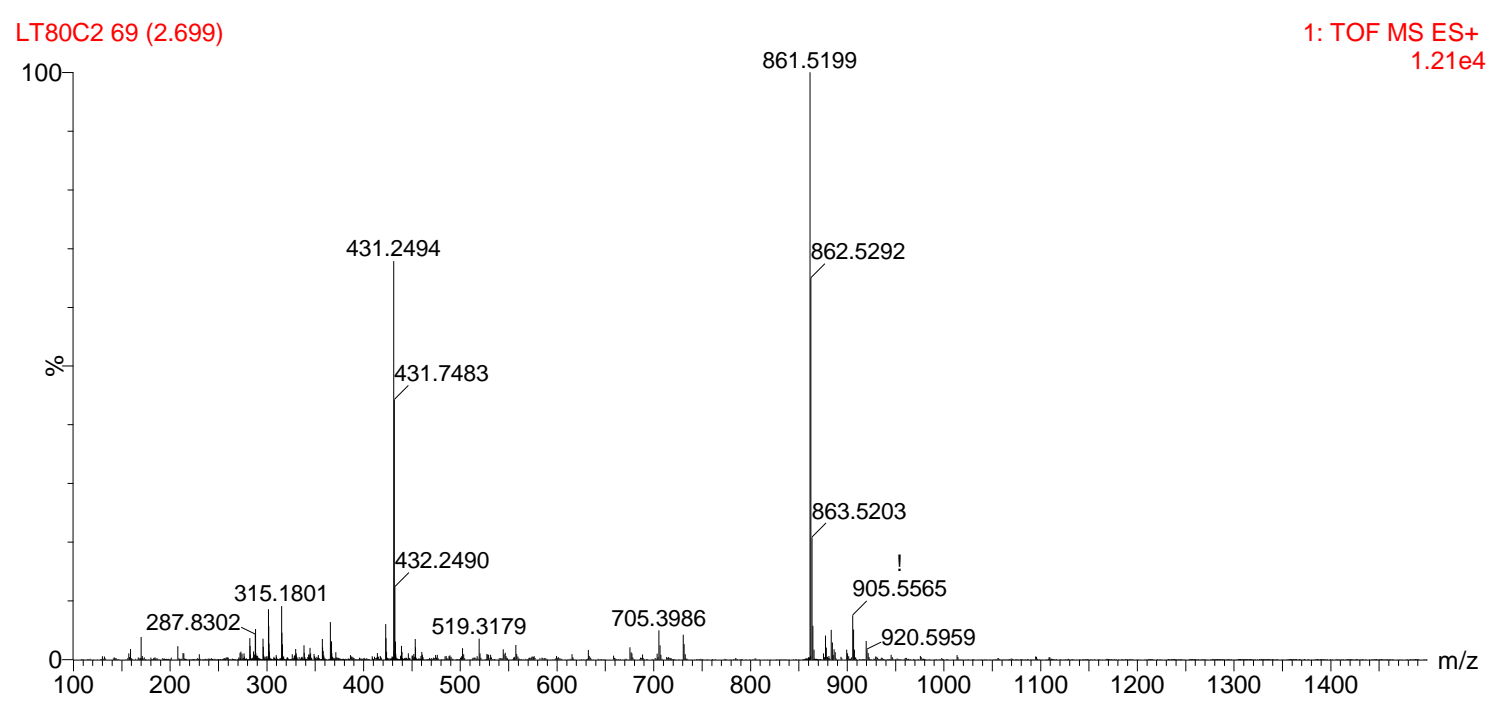

Figure S37 HRMS (ESI+) experimental spectrum of 1e 


\section{X-RAY crystal analysis}

Crystals were obtained by low evaporation of a methanolic solution of the corresponding compounds with an excess of concentrated aqueous $\mathrm{HCl}$.

\section{Crystal structure determinations}

Data for all structures were collected on a STOE IPDS II two-circle diffractometer with a Genix Microfocus tube with mirror optics using MoKa radiation $(\lambda=0.71073 \AA)$. The data were scaled using the frame scaling procedure in the X-AREA program system ${ }^{10}$. The structures were solved by direct methods using the program SHELXS ${ }^{11}$ and refined against F2 with full-matrix least-squares techniques using the program SHELXL ${ }^{12}$

In 1b, the methylene groups bonded to N1A are disordered over two sites with a site occupation factor of $0.576(11)$ for the major occupied sites. The absolute structure could be determined, Flack-x-parameter 0.05(4).

In 1d, the methylene groups bonded to N1B, N1C, N1D, N1B, N1B, and the water O atom O56 are disordered over two sites with a site occupation factor of $0.627(16), 0.652(15), 0.652(16), 0.516(15), 0.689(16), 0.52(4)$, respectively, for the major occupied sites. The displacement parameters of the atoms C17Z, C37Z and C57Z were restrained to an isotropic behavior.

The $\mathrm{H}$ atoms of the solvent water molecules could not be reliably located and were therefore omitted from the refinement. The absolute structure could be determined, Flack-x-parameter -0.01(3).

${ }^{10}$ Stoe \& Cie, X-AREA. Diffractometer control program system. Stoe \& Cie, Darmstadt, Germany, 2002.

${ }^{11}$ a) G. M. Sheldrick, Acta Crystallogr. Sect. A, 2008, 64, 112-122; b) A. L. Spek, Acta Crystallogr. Sect. D, 2009, 65, $148-155$. 


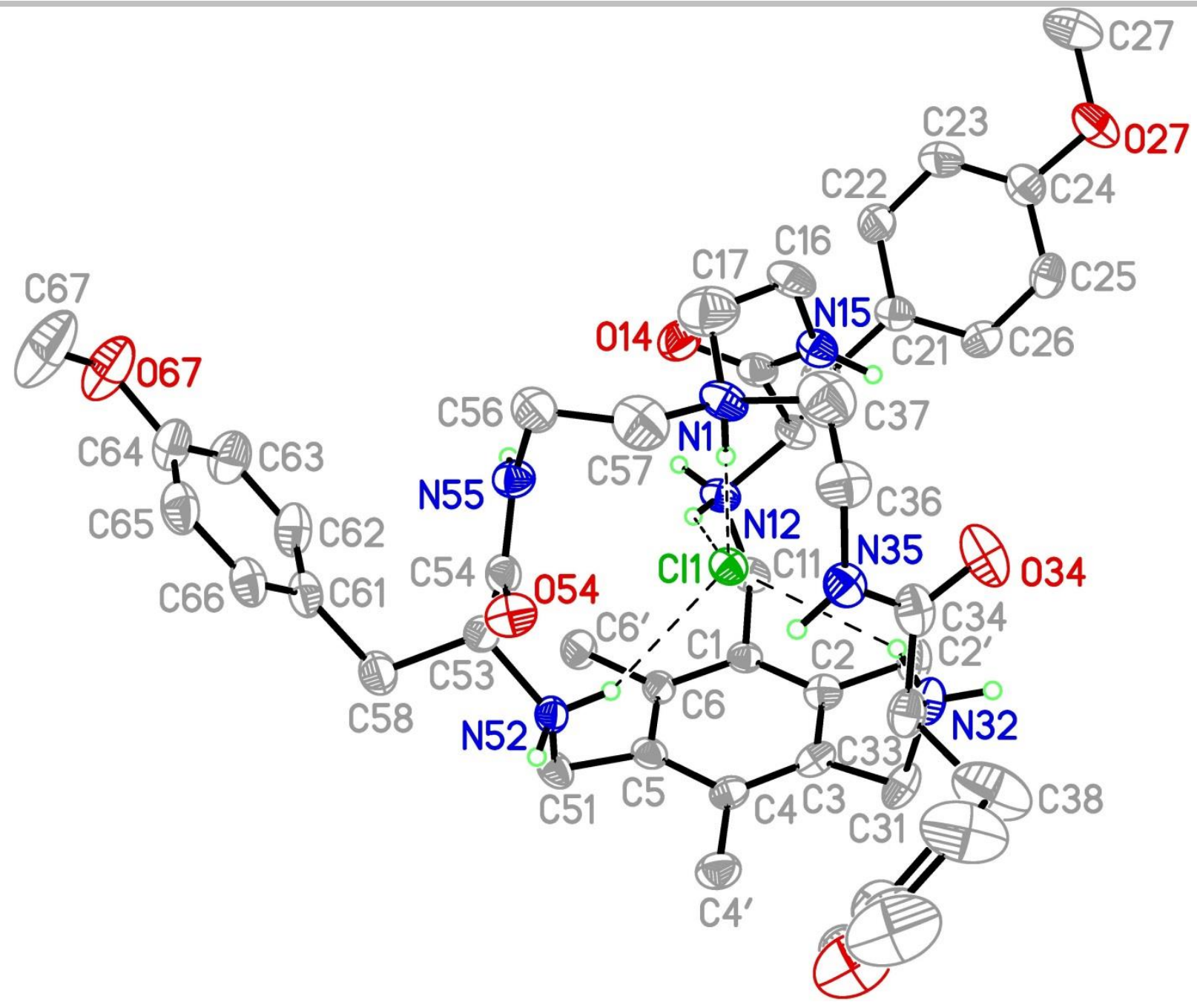

Figure S38 Perspective view of $\mathbf{1 b}$ with the atoms labels. Displacement parameters are drawn at the $50 \%$ probability level. Additional chloride counterions, solvent molecules and non-polar hydrogen atoms have been omitted for clarity. 


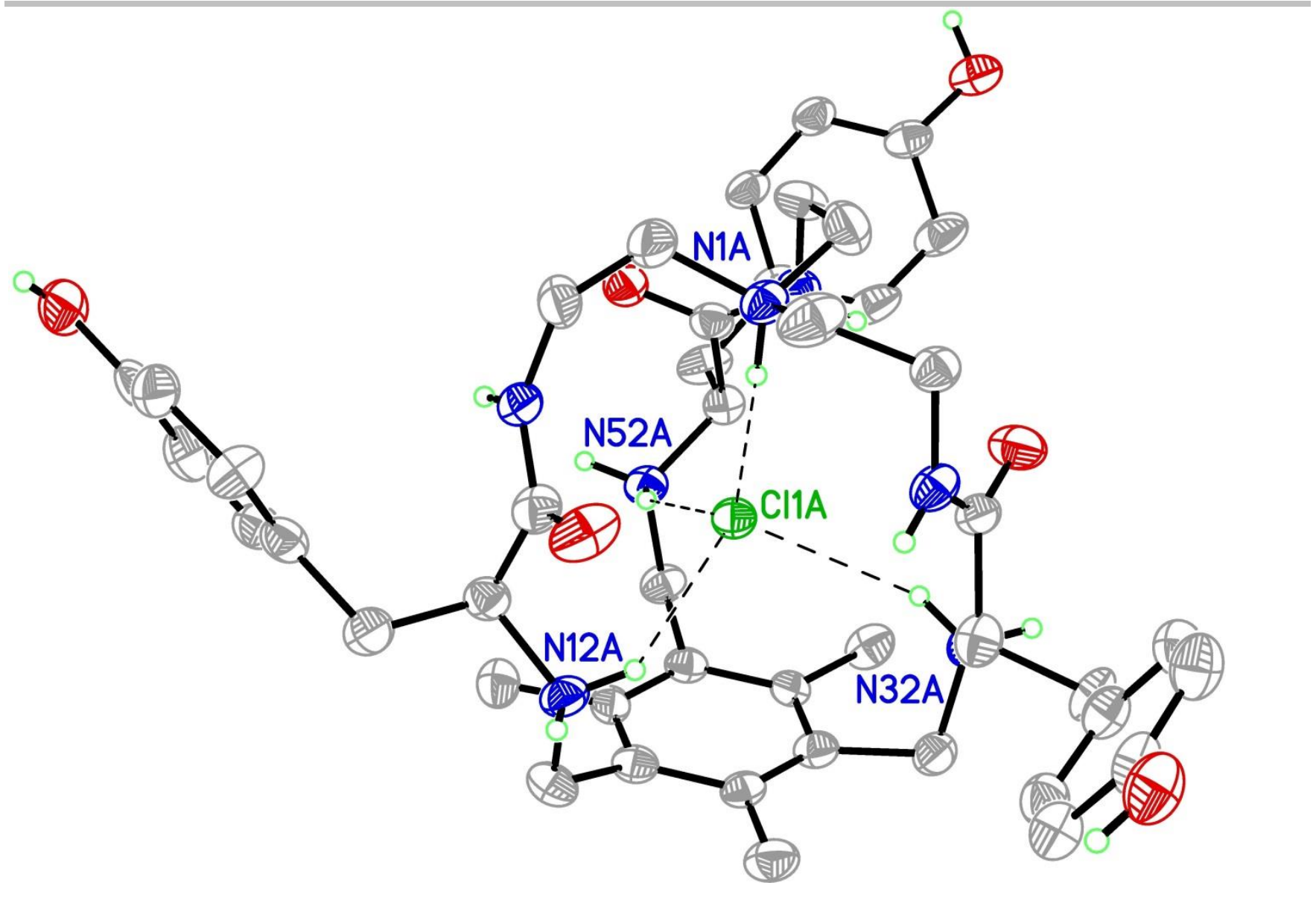

Figure S39 Perspective view of 1d with the most important atoms labels. Displacement parameters are drawn at the $30 \%$ probability level. Additional chloride counterions, solvent molecules and non-polar hydrogen atoms have been omitted for clarity. 
Table S1. Crystal data and structure refinement for $\mathbf{1 b}$.

\begin{tabular}{|c|c|c|}
\hline Identification code & $\mathrm{n} 28$ & \\
\hline Empirical formula & $\mathrm{C}_{48} \mathrm{H}_{82} \mathrm{Cl}_{4} \mathrm{~N}_{7} \mathrm{O}_{13.50}$ & \\
\hline Formula weight & 1115.00 & \\
\hline Temperature & $173(2) \mathrm{K}$ & \\
\hline Wavelength & $0.71073 \AA$ & \\
\hline Crystal system & Monoclinic & \\
\hline Space group & $P 2_{1}$ & \\
\hline \multirow[t]{3}{*}{ Unit cell dimensions } & $a=11.8632(5) \AA$ & $\alpha=90^{\circ}$ \\
\hline & $b=33.6823(12) \AA$ & $\beta=92.829(3)^{\circ}$. \\
\hline & $c=13.8741(6) \AA$ & $\gamma=90^{\circ}$ \\
\hline Volume & $5537.1(4) \AA^{3}$ & \\
\hline Z & 4 & \\
\hline Density (calculated) & $1.338 \mathrm{Mg} / \mathrm{m}^{3}$ & \\
\hline Absorption coefficient & $0.281 \mathrm{~mm}^{-1}$ & \\
\hline$F(000)$ & 2380 & \\
\hline Crystal size & $0.290 \times 0.290 \times 0.270 \mathrm{~mm}^{3}$ & \\
\hline Theta range for data collection & 1.903 to $25.404^{\circ}$ & \\
\hline Index ranges & $-14<=\mathrm{h}<=14,-34<=\mathrm{k}<=40,-16<=\mathrm{k}<=16$ & \\
\hline Reflections collected & 28973 & \\
\hline Independent reflections & $16705[\mathrm{R}$ (int) $=0.0450]$ & \\
\hline Completeness to theta $=25.000^{\circ}$ & $99.8 \%$ & \\
\hline Absorption correction & Semi-empirical from equivalents & \\
\hline Max. and min. transmission & 1.000 and 0.818 & \\
\hline Refinement method & Full-matrix least-squares on $\mathrm{F}^{2}$ & \\
\hline Data / restraints / parameters & $16705 / 1 / 1346$ & \\
\hline Goodness-of-fit on $\mathrm{F}^{2}$ & 1.029 & \\
\hline Final $R$ indices [l>2sigma(l)] & $\mathrm{R} 1=0.0602, \mathrm{wR} 2=0.1630$ & \\
\hline $\mathrm{R}$ indices (all data) & $\mathrm{R} 1=0.0667, \mathrm{wR} 2=0.1688$ & \\
\hline Absolute structure parameter & $0.05(4)$ & \\
\hline Largest diff. peak and hole & 1.316 and -1.150 e. $\AA^{-3}$ & \\
\hline
\end{tabular}


Table S2. Crystal data and structure refinement for $\mathbf{1 d}$.

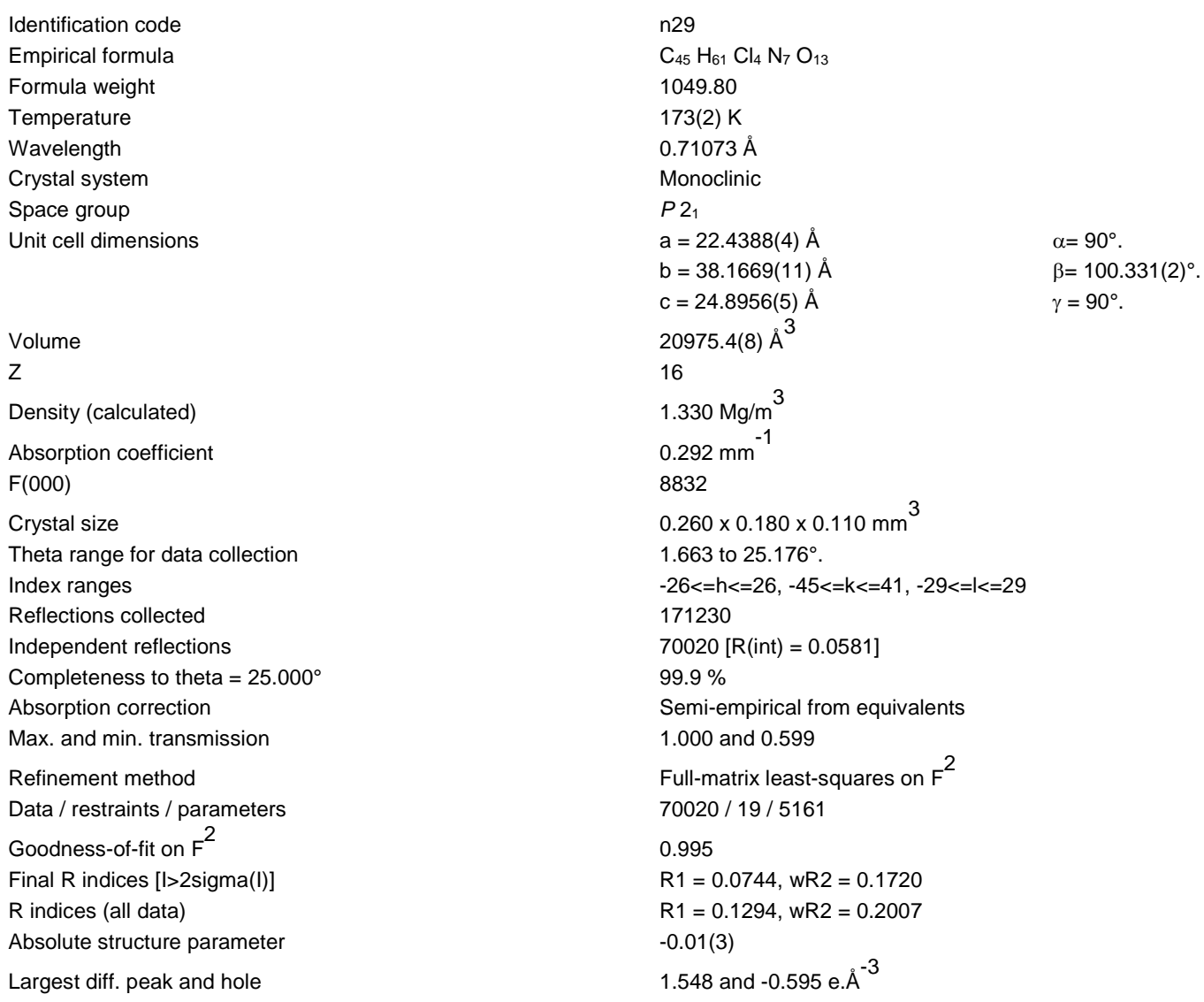




\section{Titration with Tetrabuthylamonium chloride (TBACI): Binding constants}

The titrations were performed with the cage receptor as the fully protonated molecules, using trifluoroacetic acid (TFA). The corresponding tetra-TFA salts were prepared by dissolving each compound in methanol and adding an excess of trifluoroacetic acid, followed by the solvent evaporation and drying in vacuum.

Stock solutions of the cage were prepared by weighting the corresponding amount of the receptor and reaching a final concentration between 1 and $2 \mathrm{mM}$. The solvent used was $95: 5 \mathrm{CD}_{3} \mathrm{CN}: \mathrm{H}_{2} \mathrm{O}$, since this mixture generally allowed a good solubility during the titration experiment and rendered reasonably sharp and well-defined ${ }^{1} \mathrm{H}$ NMR spectra. Besides, under these conditions, the amide proton is detectable during the titration experiments. Additionally, a stock solution of the titrant containing $0.1 \mathrm{M}$ TBACl was prepared by dissolving the salt in the stock solution of the cage. Thus, for each experiment, the solution of the titrant will be $0.1 \mathrm{M}$ in TBACl and 0.001-0.002 $\mathrm{M}$ in the receptor therefore maintaining the concentration of the cage constant during the titration experiment. The stock solution of the cage was introduced in a NMR tube and the ${ }^{1} \mathrm{H}$ NMR spectrum $(500 \mathrm{MHz}, 303 \mathrm{~K})$ was acquired, then small volumes of the stock solution of the titrant were added and the ${ }^{1} \mathrm{H}$ NMR spectrum recorded after each addition.

Different signals changed upon addition of chloride anion, and their variations were fitted using HypNMR 2008 version 4.0.71 software ${ }^{13}$. We tried different binding modes starting from the simplest 1:1 cage:chloride stoichiometry of the supramolecular complex, for which the fitting was unsatisfactory in all the cases. The simplest binding mode that led to a satisfactory fitting of all the proton signals corresponded to the formation of both 1:1 and 1:2 cage:chloride complexes. Because species with varied stoichiometry are formed in solution, for a suitable comparison of the systems, we calculated the $\mathrm{BC} 50^{\circ}$ parameter, using the $\mathrm{BC} 50$ calculator version 2.37 .1 program $^{14}$.

Following, we show the stacked plot of the NMR spectra for the titration experiments, the corresponding data set introduced (experimental) and obtained (fit) during the fitting process, the output values (both $\log \beta$ and $\mathrm{BC}_{50} 0^{\circ}$ ) for the binding for every supramolecular complex, the plot of the experimental (symbols) and the fitted (lines) values of the chemical shifts, and the plot of the simulated species distribution obtained.

Association constants for compound 1a had already been reported ${ }^{15}$.

${ }^{13}$ a) C. Frassineti, S. Ghelli, P. Gans, A. Sabatini, M.S. Moruzzi and A. Vacca, Anal Biochem 1995, 231, 374-382; b) C. Frassineti, L. Alderighi, P. Gans, A. Sabatini, A.Vacca, S. Ghelli, Anal. Bioanal. Chem. 2003, 376, 1041-1052.

${ }^{14}$ a) C. Nativi, O. Francesconi, G. Gabrielli, A. Vacca, S. Roelens, Chem. Eur. J. 2011, 17, 4814-4820; b) A. Vacca, C. Venturi, S. Roelens Chem. Eur. J. 2009, 15, 2635-2644. S. Roelens, A. Vacca, O. Francesconi, C. Venturi, Chem. Eur. J. 2009, 15, 8296-8302.

${ }^{15}$ I. Marti; J. Rubio, M. Bolte, M. I. Burguete, C. Vicent, I. Alfonso, S. V. Luis, Chem. Eur. J. 2014, 20, 7458-7464. 


\section{Titration of $\mathbf{1 b}$}

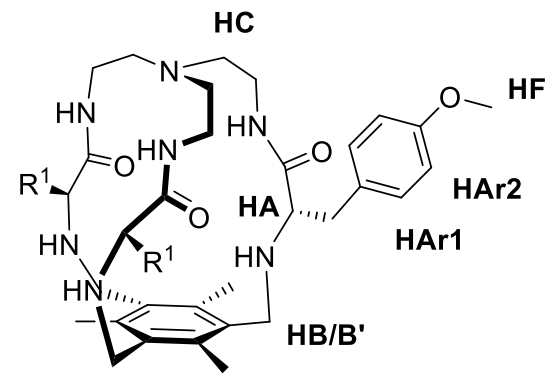

HE

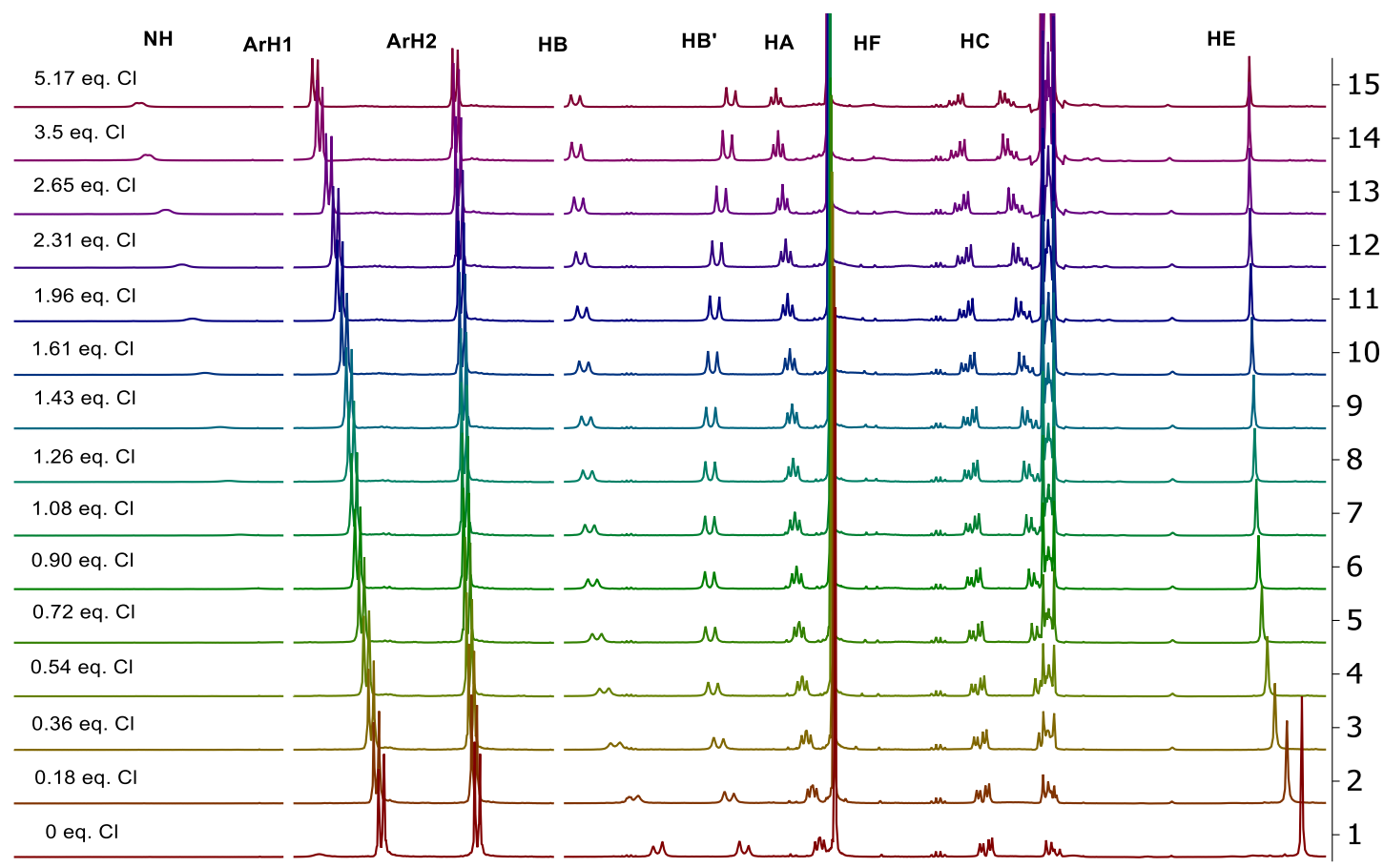

$\begin{array}{lllllllllllllllllllllll}8.8 & 8.6 & 8.4 & 8.2 & 7.4 & 7.2 & 7.0 & 6.8 & 4.6 & 4.4 & 4.2 & 4.0 & 3.8 & 3.6 & 3.4 & 3.2 & 3.0 & 2.8 & 2.6 & 2.4 & 2.2\end{array}$ f1 (ppm)

Figure S40. 1b Stacked ${ }^{1} \mathrm{H}$ NMR spectra for the titration of $\mathbf{1 b}$

Table S3. Data set of $\mathbf{1 b}$ titration:

\begin{tabular}{llllllllll}
{$[\mathrm{CI}]$} & Cl eq. & HAr2 & HAr2 fit & HB & HB fit & HB' & HB' fit & HE & HE fit \\
\hline 0.0000 & 0.0000 & 7.365 & 7.365 & 4.313 & 4.313 & 4.039 & 4.039 & 2.27 & 2.27 \\
0.0005 & 0.1815 & 7.603 & 7.5911 & 4.396 & 4.3828 & 4.086 & 4.0847 & 2.318 & 2.3167 \\
0.0011 & 0.3623 & 7.789 & 7.7828 & 4.447 & 4.4403 & 4.12 & 4.1199 & 2.356 & 2.3552 \\
0.0016 & 0.5425 & 7.926 & 7.9256 & 4.482 & 4.4808 & 4.137 & 4.1409 & 2.38 & 2.3823 \\
0.0022 & 0.7220 & 8.025 & 8.0236 & 4.505 & 4.5059 & 4.146 & 4.1495 & 2.397 & 2.399 \\
0.0027 & 0.9009 & 8.092 & 8.0919 & 4.519 & 4.5213 & 4.148 & 4.1507 & 2.408 & 2.4091 \\
0.0032 & 1.0791 & 8.133 & 8.1427 & 4.528 & 4.5313 & 4.148 & 4.1485 & 2.415 & 2.4157 \\
0.0038 & 1.2567 & 8.175 & 8.183 & 4.535 & 4.5383 & 4.146 & 4.1447 & 2.42 & 2.4202 \\
0.0043 & 1.4337 & 8.206 & 8.2162 & 4.539 & 4.5435 & 4.144 & 4.1404 & 2.423 & 2.4236 \\
0.0048 & 1.6100 & 8.25 & 8.2444 & 4.547 & 4.5476 & 4.139 & 4.1359 & 2.429 & 2.4262 \\
0.0059 & 1.9608 & 8.289 & 8.2904 & 4.553 & 4.5536 & 4.132 & 4.1273 & 2.432 & 2.43
\end{tabular}




\begin{tabular}{llllllllll}
\hline 0.0069 & 2.3091 & 8.323 & 8.3267 & 4.557 & 4.558 & 4.125 & 4.1195 & 2.435 & 2.4327 \\
0.0080 & 2.6549 & 8.372 & 8.3562 & 4.564 & 4.5613 & 4.111 & 4.1127 & 2.437 & 2.4348 \\
0.0105 & 3.5088 & 8.43 & 8.4108 & 4.571 & 4.5669 & 4.092 & 4.0991 & 2.438 & 2.4383 \\
0.0155 & 5.1724 & 8.458 & 8.4756 & 4.573 & 4.5731 & 4.081 & 4.0818 & 2.438 & 2.442
\end{tabular}

\section{Results of the HypNMR fitting:}

$\log B 1=3.69 \pm 0.1(1: 1)$

$\log B 2=5.89$ (1:2) excessive relative error on beta $=37 \%$

$\mathrm{BC}_{50}: 198 \pm 44 \mu \mathrm{M}$

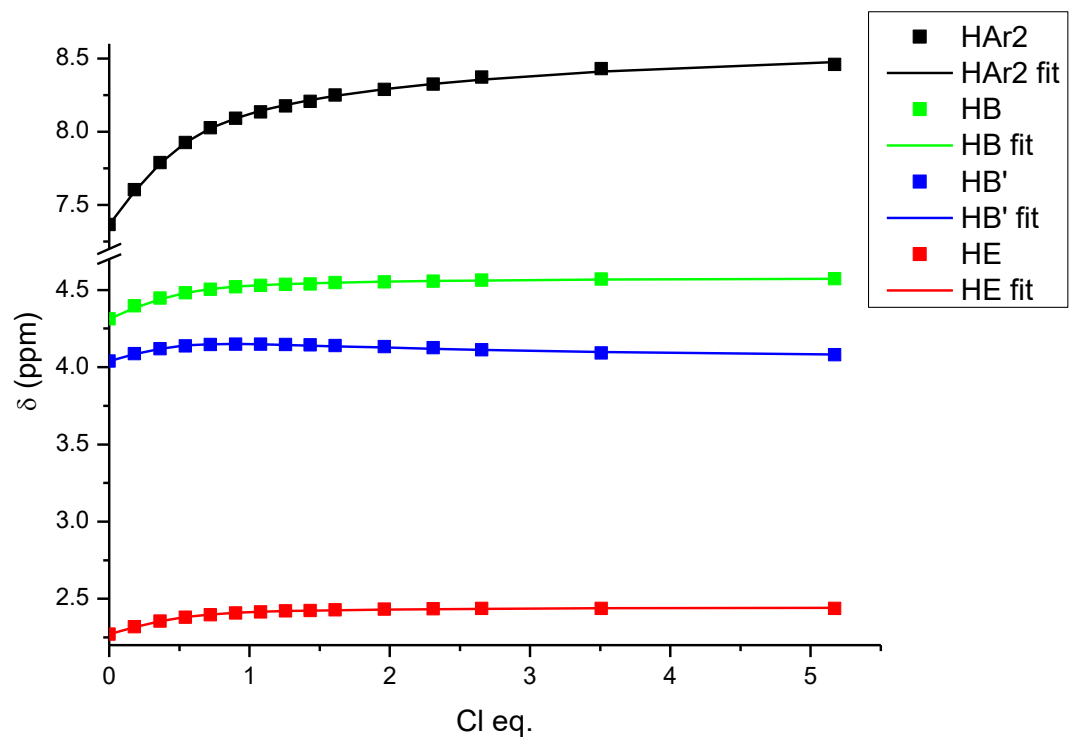

Figure S41. Plot of the experimental (symbols) and fitting (lines) data in $\mathbf{1 b}$ titration

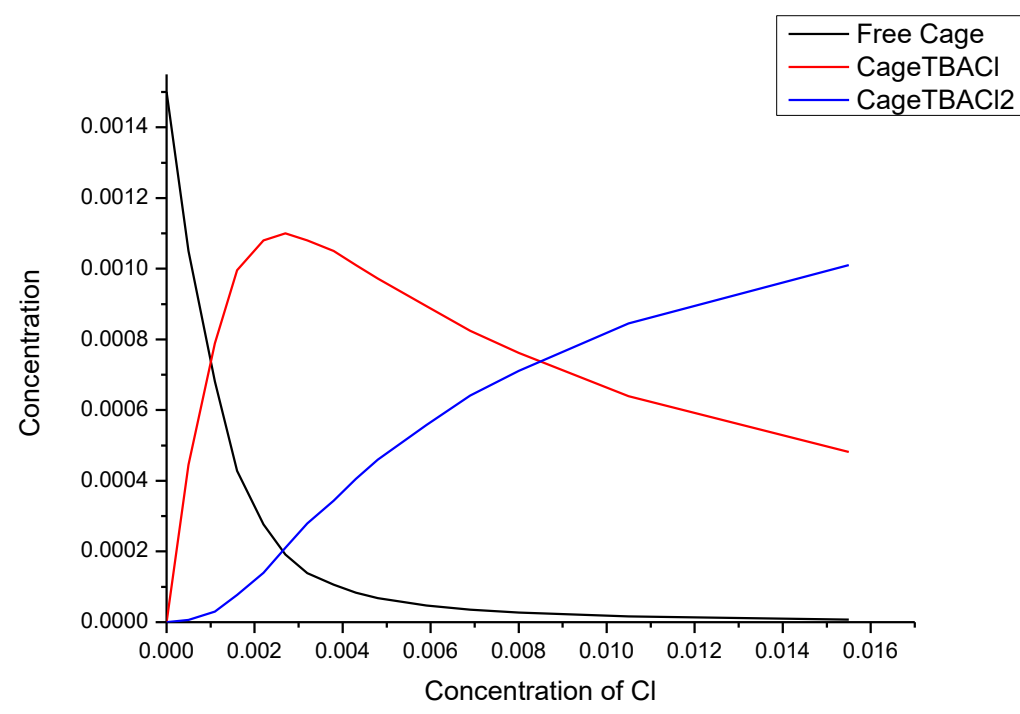

Figure S42. Species distribution as a function of the chloride concentration in $\mathbf{1 b}$ titration. 


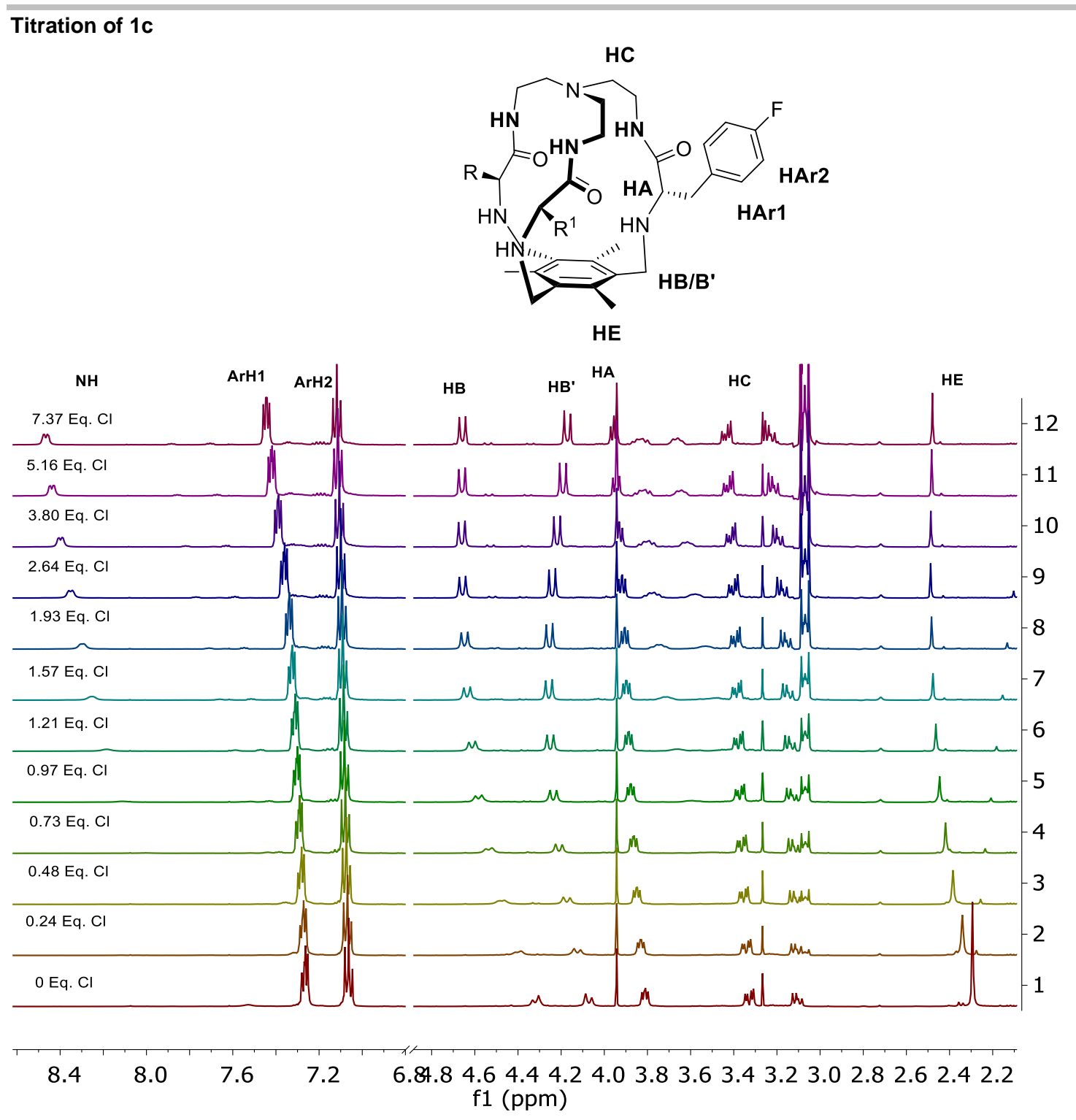

Figure S43. 1c Stacked ${ }^{1} \mathrm{H}$ NMR spectra for the titration of 1c

Table S4. Data set of 1c titration:

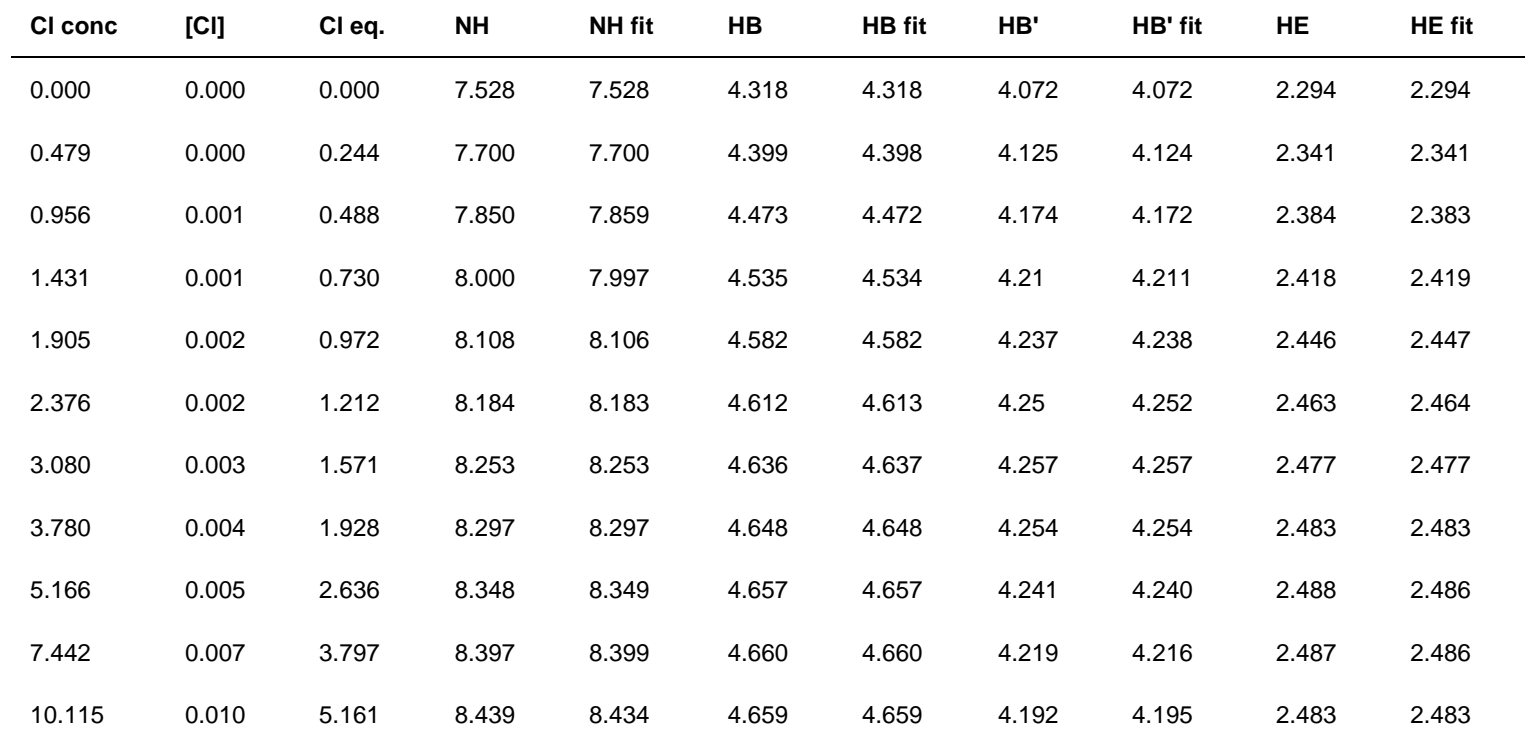




$\begin{array}{llllllllll}14.436 & 0.014 & 7.365 & 8.467 & 8.470 & 4.658 & 4.658 & 4.171 & 4.171 & 2.479\end{array}$

Results of the HypNMR fitting:

$\log B 1=3.82 \pm 0.028(1: 1)$

$\log B=2: 5.99 \pm 0.058(1: 2)$

$\mathrm{BC}_{50}: 148 \pm 10 \mu \mathrm{M}$

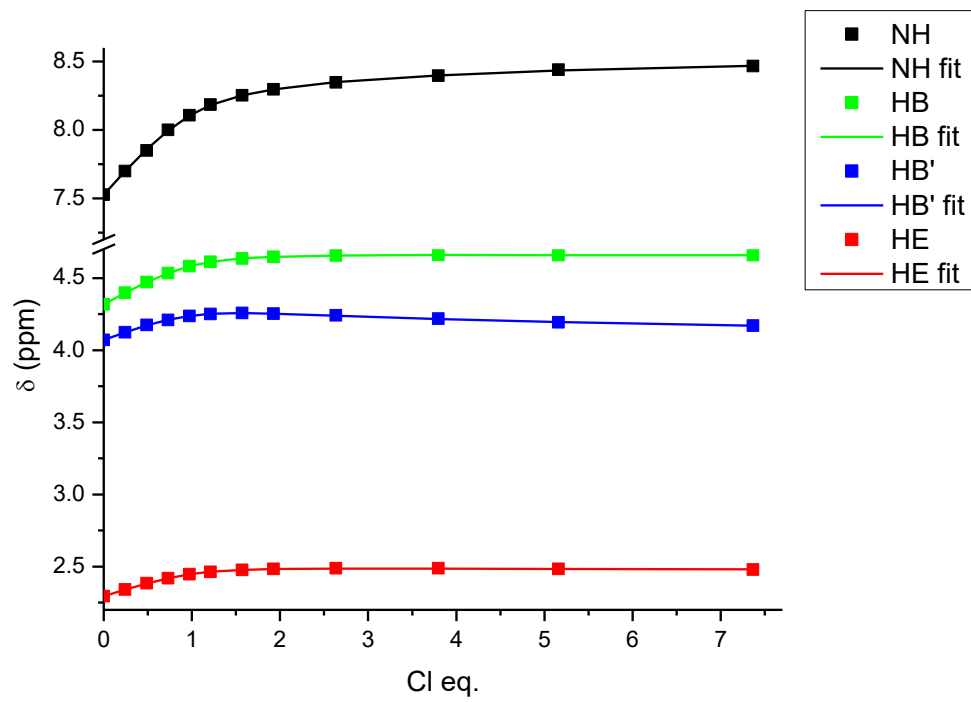

Figure S44. Plot of the experimental (symbols) and fitting (lines) data of 1c titration

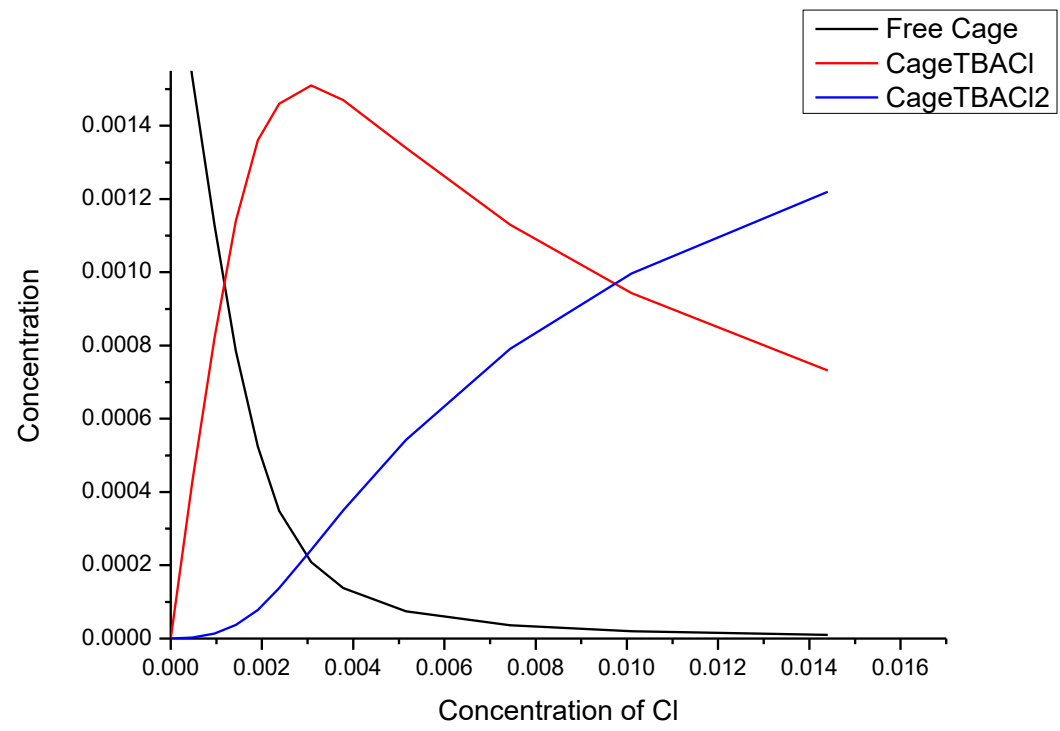

Figure S45. Species distribution as a function of the chloride concentration of $1 \mathrm{c}$ titration. 


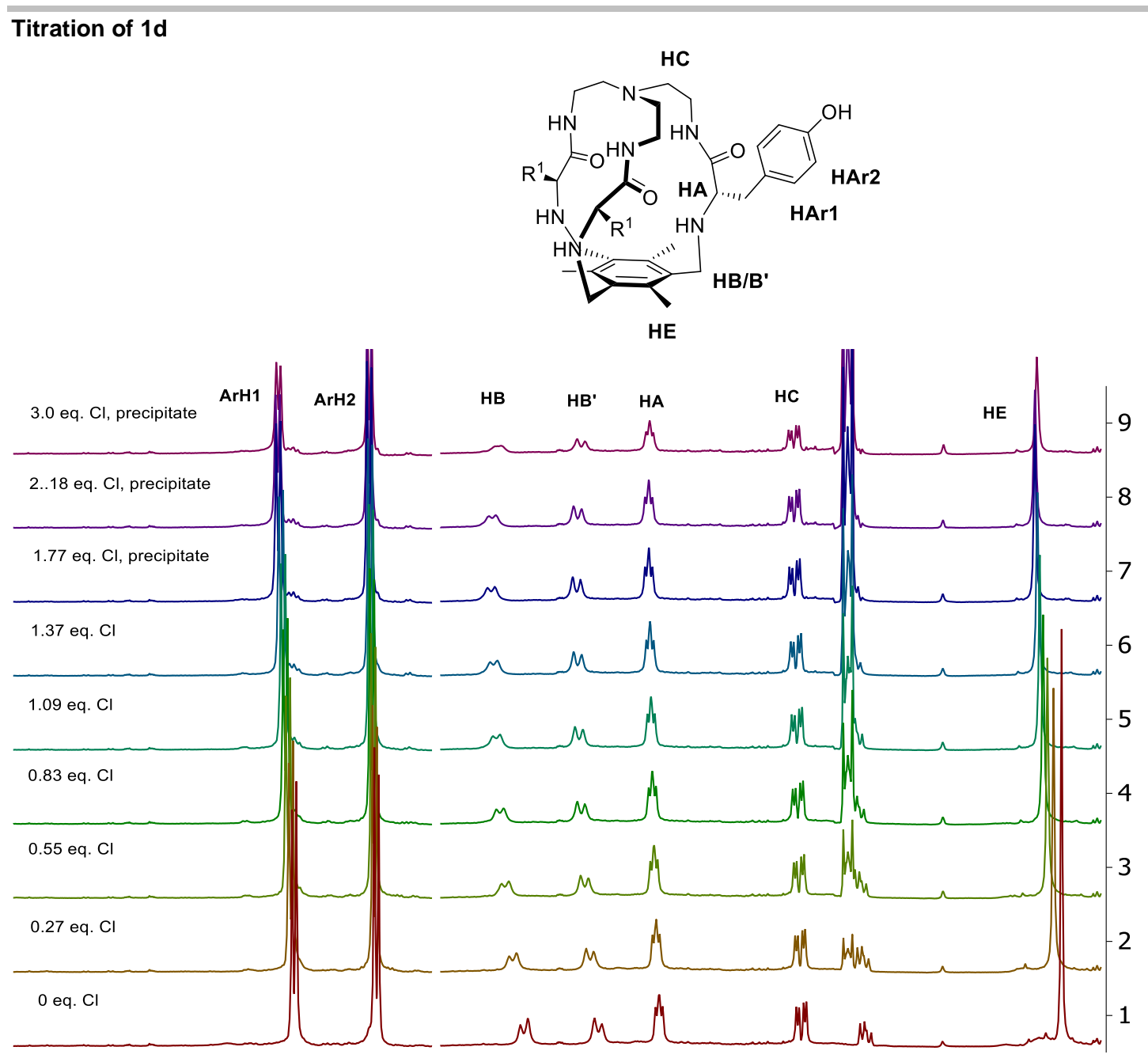

$\begin{array}{llllllllllllllllllllll}8.0 & 7.8 & 7.6 & 7.4 & 7.2 & 7.0 & 6.8 & 6.64 .6 & 4.4 & 4.2 & 4.0 & 3.8 & 3.6 & 3.4 & 3.2 & 3.0 & 2.8 & 2.6 & 2.4 & 2.2\end{array}$ f1 (ppm)

Figure S46. 1d Stacked ${ }^{1} \mathrm{H}$ NMR spectra for the titration of $\mathbf{1 d}$

Tyrosine cage 1d starts to precipitate when we add more than one equivalent of TBACl, so association constants in this case are harder to determine. However, it was observed that first and second association constants are within the same order of magnitude, data that we obtain if we fix one value and optimize by fitting the other one. Nuclei used for the adjustment were ArH1. HB/B' and HE.

Table S5. Data set of 1d titration:

\begin{tabular}{|c|c|c|c|c|c|c|c|c|c|}
\hline$[\mathrm{Cl}]$ & $\mathrm{Cl}$ eq. & HAr1 & HAr1 fit & HB & HB fit & HB' & HB'fit & HE & HE fit \\
\hline 0.0000 & 0.0000 & 7.0630 & 7.0630 & 4.3050 & 4.3050 & 4.0230 & 4.0230 & 2.2520 & 2.2522 \\
\hline 0.0005 & 0.2766 & 7.0760 & 7.0755 & 4.3490 & 4.3490 & 4.0540 & 4.0544 & 2.2830 & 2.2834 \\
\hline 0.0010 & 0.5521 & 7.0860 & 7.0863 & 4.3780 & 4.3783 & 4.0750 & 4.0744 & 2.3060 & 2.3057 \\
\hline 0.0015 & 0.8266 & 7.0960 & 7.0961 & 4.4000 & 4.3990 & 4.0880 & 4.0880 & 2.3230 & 2.3227 \\
\hline 0.0020 & 1.0999 & 7.1050 & 7.1050 & 4.4120 & 4.4132 & 4.0960 & 4.0965 & 2.3350 & 2.3356 \\
\hline 0.0025 & 1.3721 & 7.1130 & 7.1129 & 4.4220 & 4.4215 & 4.1010 & 4.1007 & 2.3450 & 2.3448 \\
\hline
\end{tabular}

Results of the HypNMR fitting:

$\log B 1=3.74 \pm 0.04(1: 1)$

$\log B 2=7.45 \pm 0.5(1: 2)$ 
$\mathrm{BC}_{50}: 115 \pm 34 \mu \mathrm{M}$

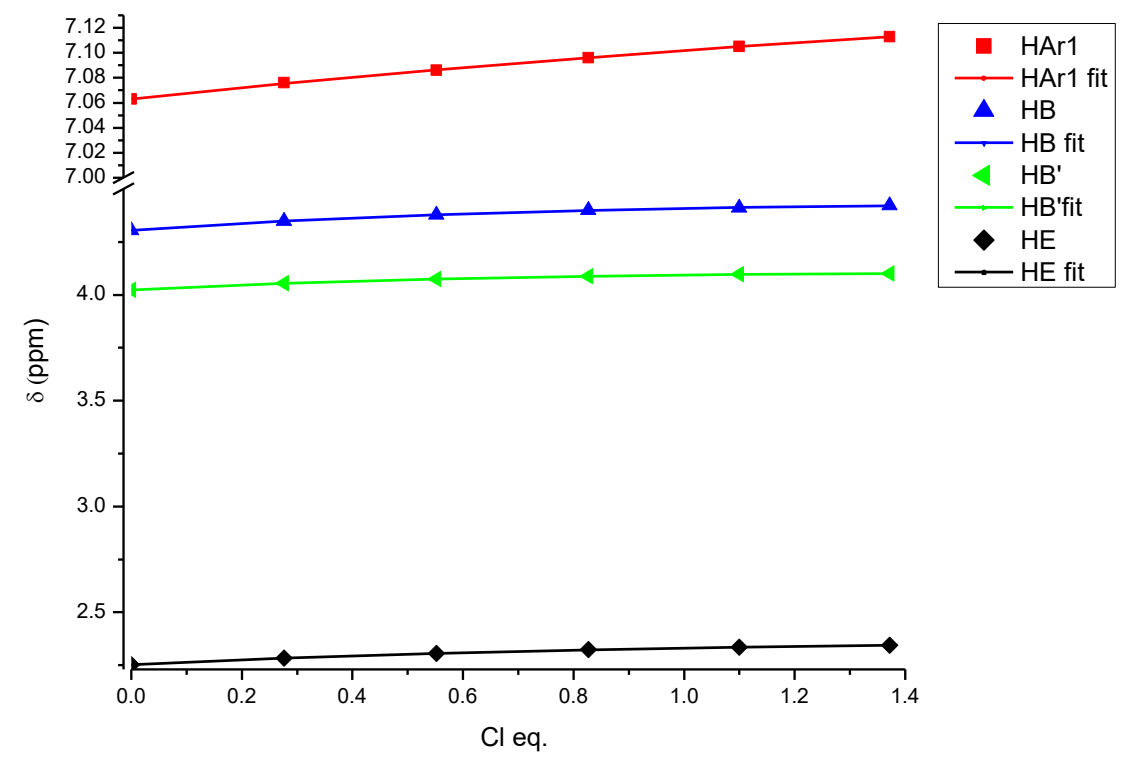

Figure S47. Plot of the experimental (symbols) and fitting (lines) data of $1 \mathbf{d}$ titration

Species distribution as a function of the chloride concentration. In this case the specie distribution is not accurate due to precipitation events of the 1:2 complex that is displacing the equilibrium towards the complexation of the cage.

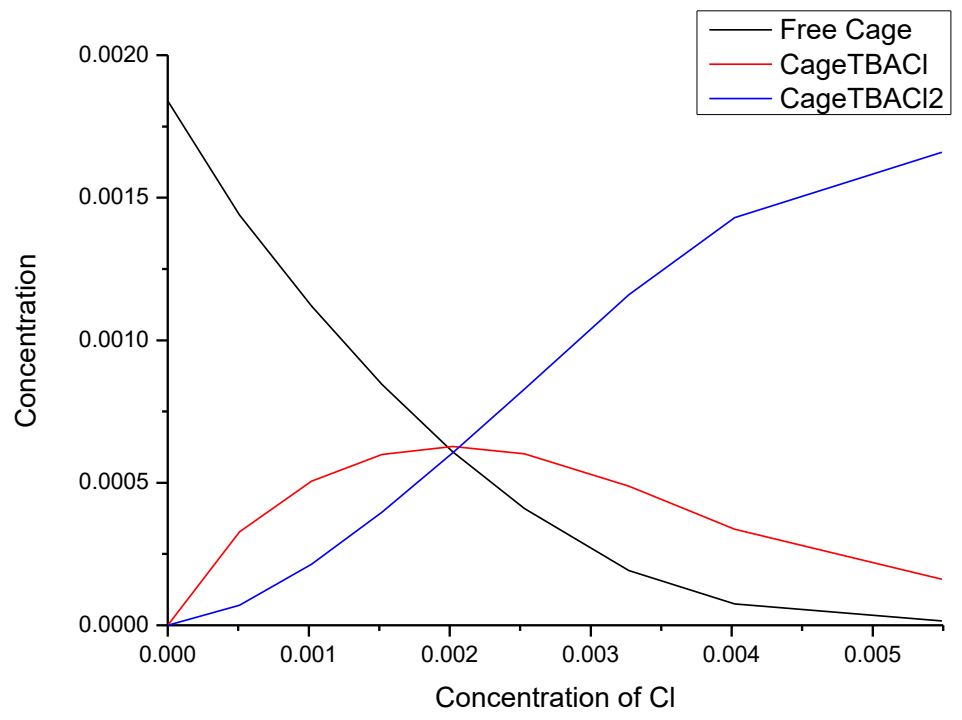

Figura S48. Species distribution as a function of the chloride concentration in $\mathbf{1 d}$ titration 
Titration of 1e

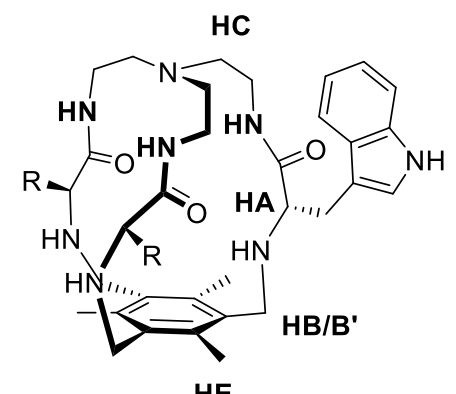

HE

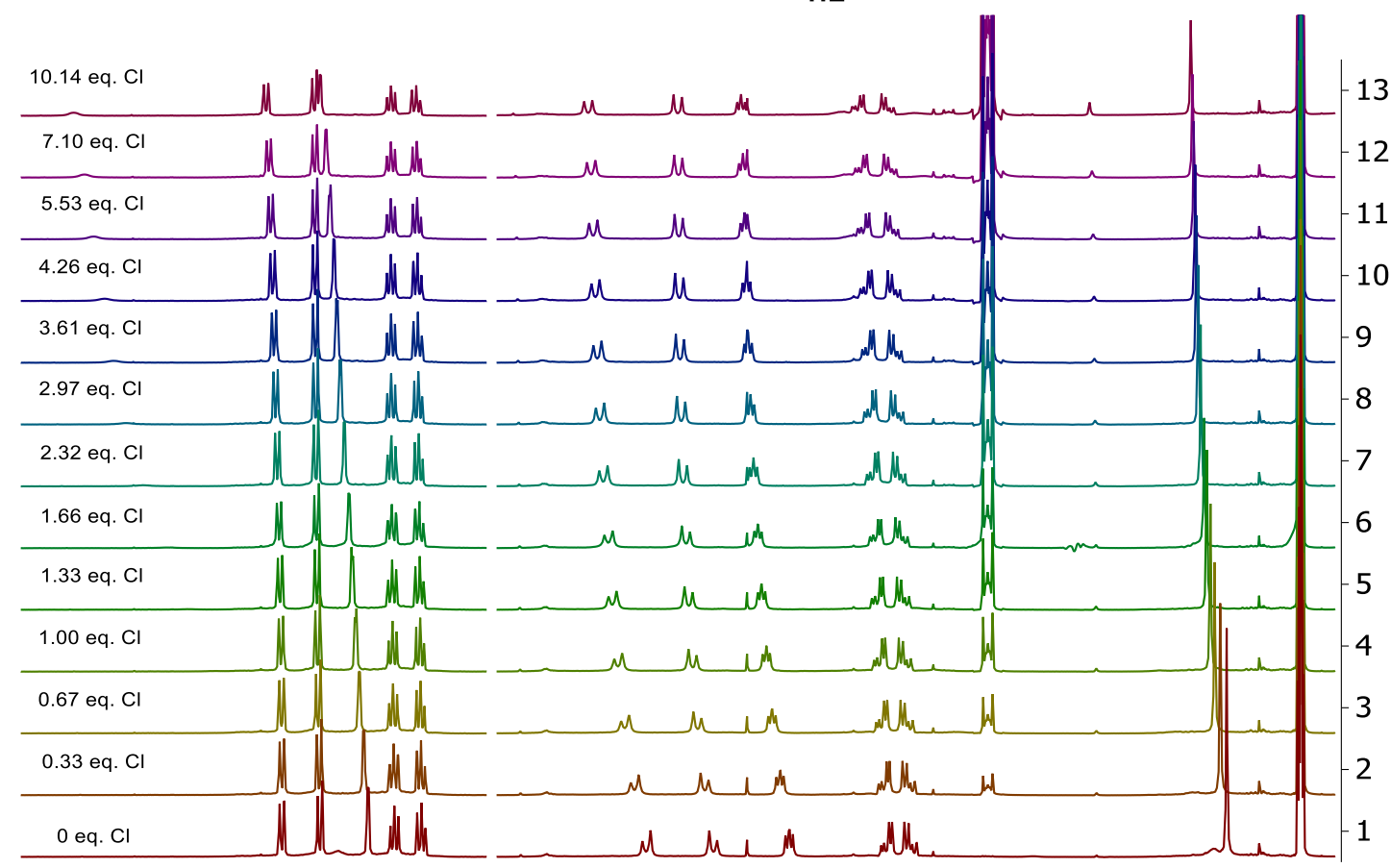

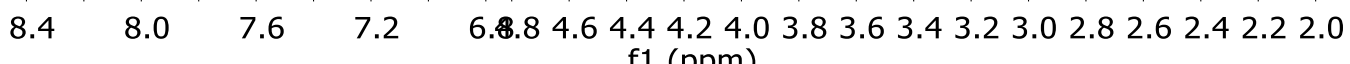

f1 (ppm)

Figure S.49. 4e Stacked ${ }^{1} \mathrm{H}$ NMR spectra for the titration of $1 \mathrm{e}$

Table S6. Data set of 1e titration

\begin{tabular}{|c|c|c|c|c|c|c|c|c|c|c|c|}
\hline$[\mathrm{Cl}]$ & $\mathrm{Cl}$ eq & $\mathrm{NHa}$ & NHa fit & $\mathrm{NHb}$ & $\mathrm{NHb}$ fit & $\mathrm{HB}$ & HB fit & $\mathrm{HB}^{\prime}$ & HB'fit & HA & HA fit \\
\hline 0.00000 & 0.00 & 9.67 & 9.67 & 7.34 & 7.34 & 4.31 & 4.31 & 4.07 & 4.07 & 3.79 & 3.79 \\
\hline 0.00028 & 0.33 & 9.69 & 9.69 & & 7.52 & 4.35 & 4.35 & 4.10 & 4.10 & 3.83 & 3.83 \\
\hline 0.00056 & 0.67 & 9.70 & 9.70 & & 7.67 & 4.39 & 4.38 & 4.13 & 4.12 & 3.86 & 3.85 \\
\hline 0.00084 & 1.00 & 9.72 & 9.72 & 7.79 & 7.79 & 4.41 & 4.41 & 4.14 & 4.14 & 3.88 & 3.88 \\
\hline 0.00112 & 1.33 & 9.73 & 9.73 & 7.88 & 7.88 & 4.43 & 4.43 & 4.16 & 4.16 & 3.89 & 3.89 \\
\hline 0.00140 & 1.66 & 9.74 & 9.74 & 7.96 & 7.95 & 4.45 & 4.45 & 4.17 & 4.17 & 3.91 & 3.91 \\
\hline 0.00195 & 2.32 & 9.76 & 9.76 & 8.04 & 8.05 & 4.47 & 4.47 & 4.18 & 4.18 & 3.92 & 3.92 \\
\hline 0.00250 & 2.97 & 9.77 & 9.77 & 8.11 & 8.11 & 4.48 & 4.48 & 4.18 & 4.19 & 3.93 & 3.93 \\
\hline 0.00304 & 3.62 & 9.79 & 9.78 & 8.15 & 8.15 & 4.49 & 4.49 & 4.19 & 4.19 & 3.94 & 3.94 \\
\hline 0.00358 & 4.26 & 9.80 & 9.80 & 8.18 & 8.18 & 4.49 & 4.49 & 4.19 & 4.19 & 3.95 & 3.95 \\
\hline 0.00465 & 5.53 & 9.81 & 9.81 & 8.22 & 8.22 & 4.50 & 4.50 & 4.19 & 4.19 & 3.95 & 3.95 \\
\hline
\end{tabular}




\begin{tabular}{|c|c|c|c|c|c|c|c|c|c|c|c|}
\hline 0.00596 & 7.10 & 9.83 & 9.83 & 8.25 & 8.25 & 4.51 & 4.51 & 4.19 & 4.19 & 3.96 & 3.96 \\
\hline 0.00852 & 10.2 & 9.85 & 9.85 & 8.29 & 8.29 & 4.52 & 4.52 & 4.20 & 4.19 & 3.96 & 3.96 \\
\hline
\end{tabular}

Results of the HypNMR fitting:

$\log B 1=3.40 \pm 0.03(1: 1)$

$\log B 2=5.53 \pm 0.12(1: 2)$

$\mathrm{BC}_{50}: 380 \pm 24 \mu \mathrm{M}$

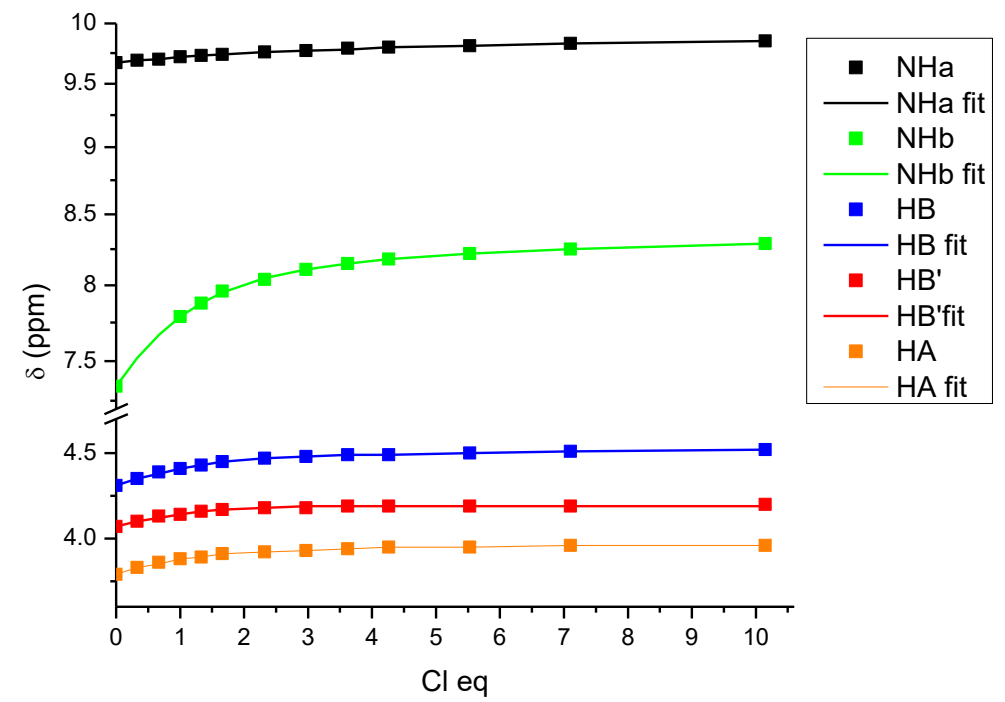

Figure S.50.Plot of the experimental (symbols) and fitting (lines) data in 1e titration

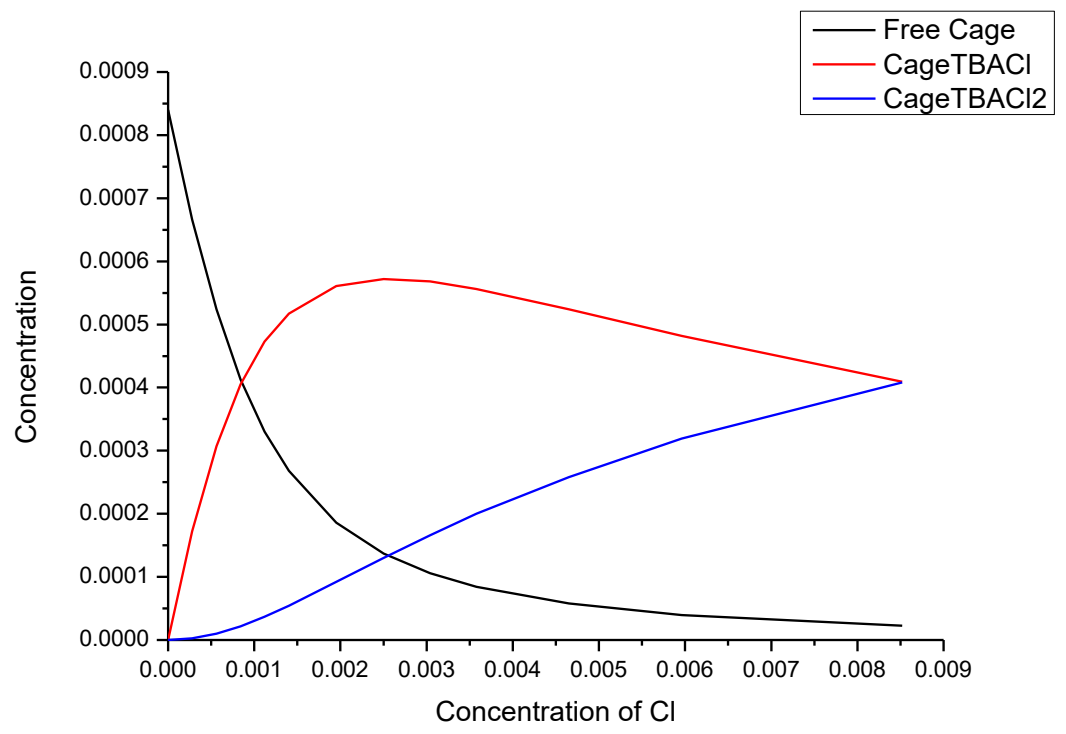

Figure S51. Species distribution as a function of the chloride concentration in 1e titration. 


\section{LOG P calculation and Retention time determination}

LogP values for compounds were calculated using VCCLab software. This software allows the calculation of LogP using different methods such as ALOGPS, AC LogP, ALOGP, MLOGP, MiLOGP, XLOPGP2 or XLOGP3, and we used consensus LogP as the average of these values. Neutral (for logP1) and tetraprotonated (for LogP2) forms of the pseudopeptidic tripodal small cages were considered. The results are summarized in Table S7. Reverse phase HPLC (equipment: Agilent technologies 1100 series, column: Xterra MS C18 4.6*150 mm (5 $\mu \mathrm{M})$ ) was also used for measuring the relative lipophilicity of these compounds, since the retention time of each molecule on the reverse phase column is related to its lipophilicity.

All the products were dissolved in $\mathrm{MeOH}$ at concentration of $1 \mathrm{mM}$ and eluted using a linear gradient of $20 \%$ to $100 \%$ of acetonitrile in water (using $0.1 \%$ of trifluoroacetic acid) in 20 minutes.

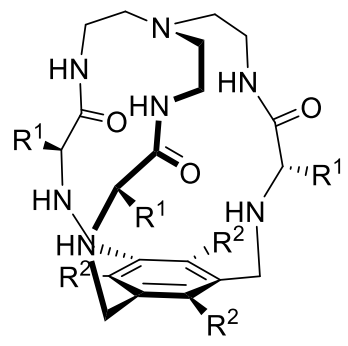

Neutral cage

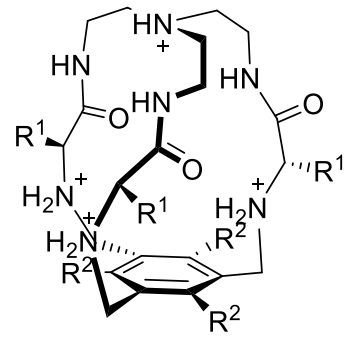

Tetraprotonated cage

Figure S52. General structures of the neutral and tetraprotonated cage.

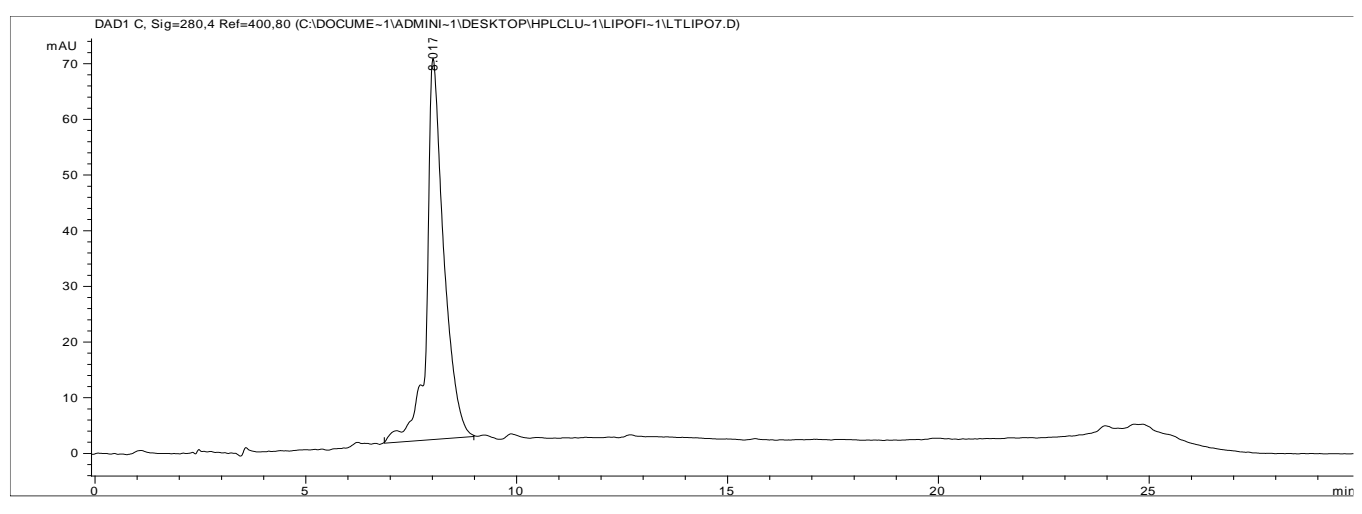

Figure S53. HPLC chromatogram of compound 1a

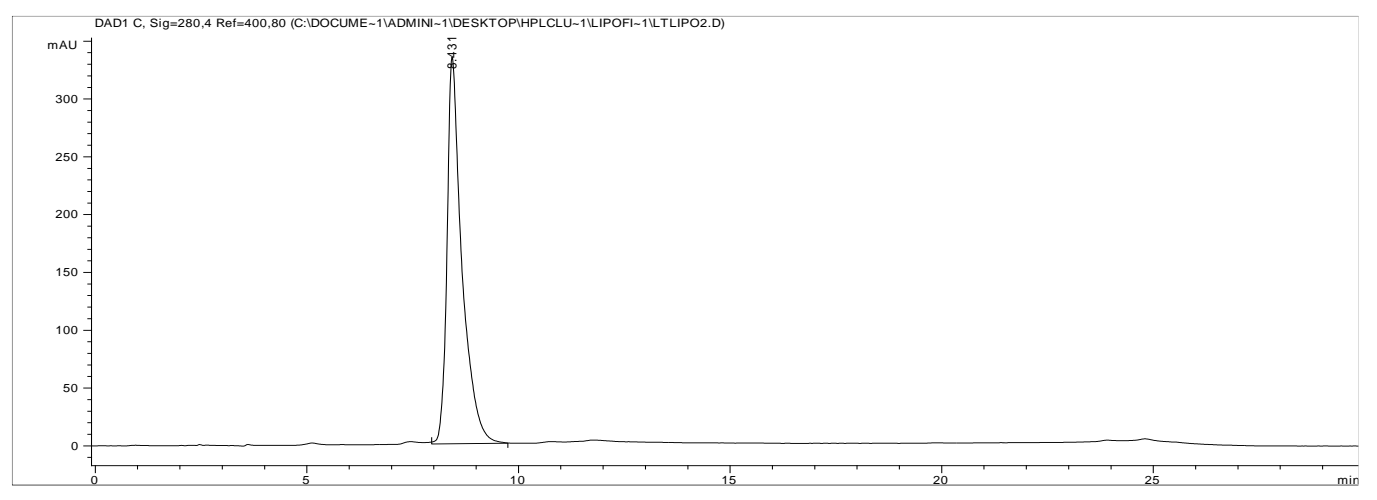

Figure S54. HPLC chromatogram of compound 1b 


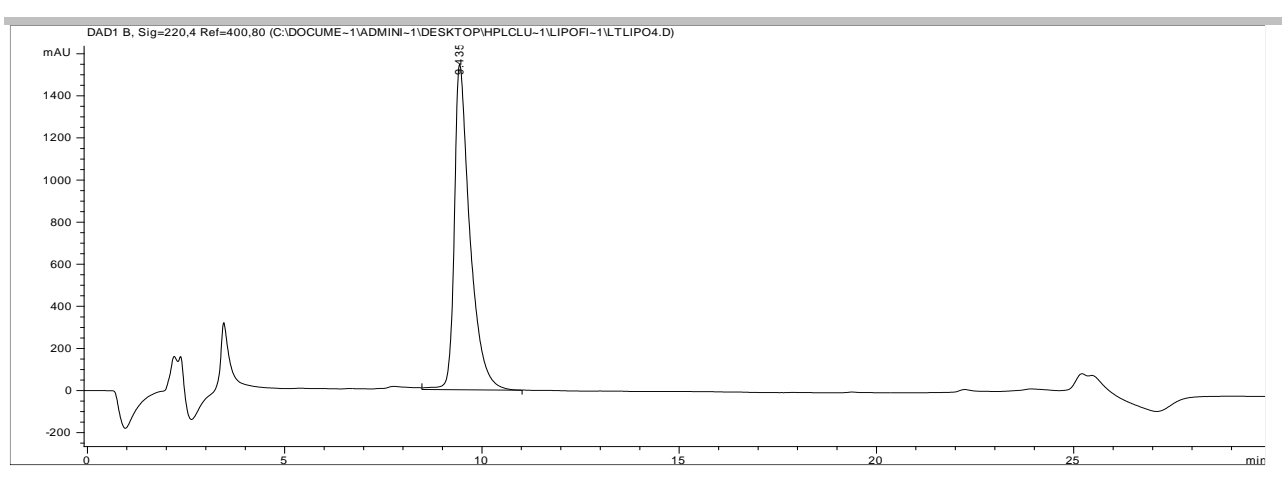

Figure S55. HPLC chromatogram of compound 1c

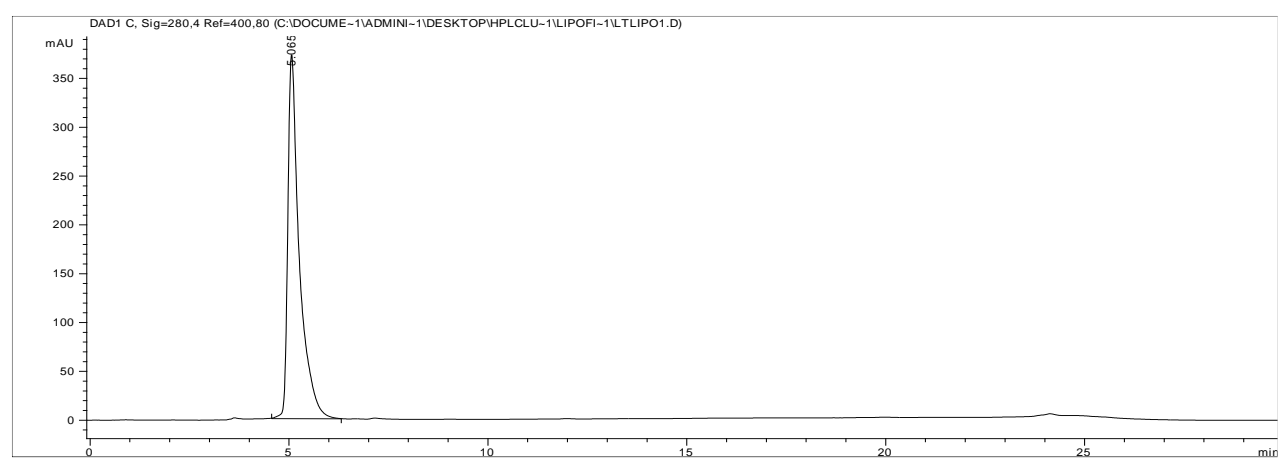

Figure S56. chromatogram of compound 1d

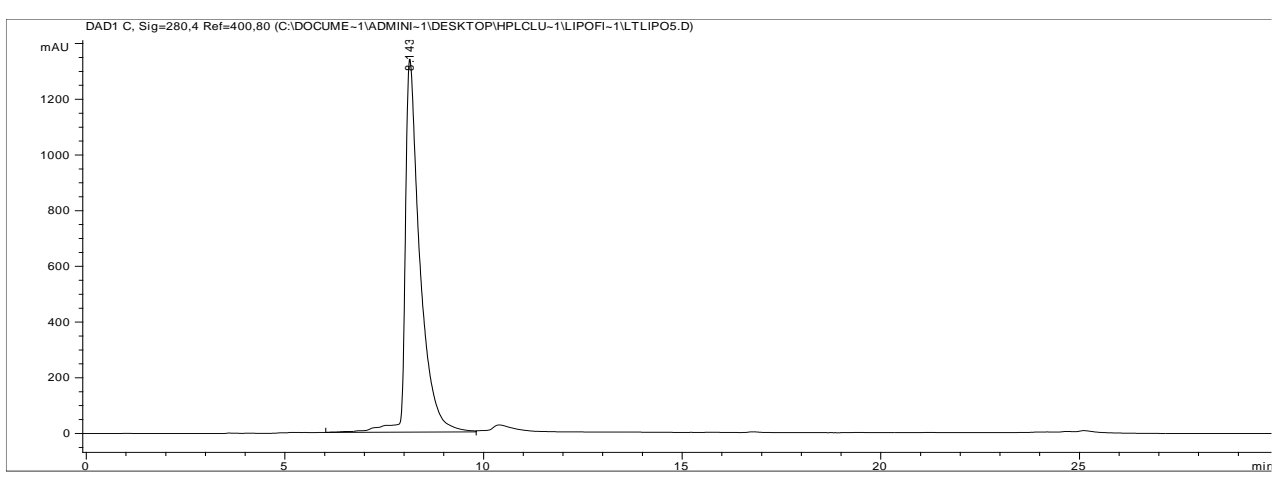

Figure S57. HPLC chromatogram of compound 1e

Table S7.: calculated Log P values and retention times (minutes). Log P1 correspond to the non-protonated cage and Log P2 corresponds to the tetraprotonated form of the cage.

\begin{tabular}{ccccc}
\hline Cage & LogP1 & LogP2 & Average LogP1 and LogP2 & Retention time (min) \\
\hline $\mathbf{1 a}$ & 3.56 & 0.26 & 1.91 & 8.017 \\
\hline $\mathbf{1 b}$ & 3.63 & 0.1 & 1.865 & 8.431 \\
\hline $\mathbf{1 c}$ & 4.31 & 0.77 & 2.54 & 9.435 \\
\hline $\mathbf{1 d}$ & 2.81 & -0.69 & 1.06 & 5.067 \\
\hline $\mathbf{1 e}$ & 4.04 & 0.7 & 2.37 & 8.148 \\
\hline
\end{tabular}




\section{Vesicles transport assays}

\section{Preparation of vesicles}

Vesicles composed of POPC (1-palmitoyl-2- oleoyl-sn-glycero-3-phosphocholine) or POPC and cholesterol were used. POPC and cholesterol stock solutions were prepared in chloroform and were kept in the freezer. In a standard preparation $2 \mathrm{~mL}$ of POPC stock solution $(20 \mathrm{mg} / \mathrm{mL}=26.32 \mathrm{mM})$ were added to a $5 \mathrm{~mL}$ round bottom flask. The solvent was evaporated using a rotary evaporator ( 20 ${ }^{\circ} \mathrm{C}$ ) and dried overnight under high vacuum. On the next morning, the obtained lipid film was rehydrated with $1 \mathrm{~mL}$ of the required internal solution corresponding to each assay, followed by careful vortexing. The obtained lipid suspension, composed of multilamellar vesicles with different sizes, was subjected to seven freeze-and-thaw cycles. At this point, the lipid solution was made of unilamellar vesicles with different sizes. In order to standardize the size, the suspension was extruded through 200 nm polycarbonate nucleopore membrane using a LiposoFast Basic extruder (Avestin, Inc.) 29 times. Once the vesicles were prepared, the next step was to remove the non-encapsulated contents of the rehydrating solution. There are two different manners of carrying this out. One of them consists in placing the lipid suspension in a dialysis membrane and dialyse it against the external required solution (2 times $x 500 \mathrm{~mL})$. This method was used for ISE experiments. The other method consists in carrying out a Size Exclusion Chromatography (SEC) on a Sephadex G-50 column. This method was used for removing fluorescent dyes. Finally, the vesicles suspension was place in a volumetric flask, to obtain a stock liposome suspension of known lipid concentration

\section{Transport assays}

\section{Potentiometric transport assays. Chloride selective electrode assays.}

This assay is focused on determining the chloride concentration using a Chloride Selective Electrode (Ion Selective Electrode, ISE) ${ }^{16}$ POPC vesicles were prepared as previously described. All ISE assays were carried out using a total volume of $5000 \mu \mathrm{L}$. Unilamellar vesicles were suspended in the external solution to give a final lipid concentration of $0.5 \mathrm{mM}$ POPC. At $t=60 \mathrm{~s}$ (unless other specification), a DMSO solution of the anion carrier was added to the sample. The volume of stock solution added was always smaller than $25 \mu \mathrm{L}$ in order to avoid influence of the solvent. The chloride efflux from the vesicles was monitored over time, using the combination chloride selective electrode. At $t=300 \mathrm{~s}$, a $20 \mu \mathrm{L}$ pulse of Triton X-10\% (v/v) (detergent) was added in order to lyse the vesicles and release all chloride anions. This total value of chloride anions was considered as $100 \%$ and the rest of data points were normalized as a function of it. Data was expressed as percentage of $\mathrm{Cl}^{-}$efflux over time. The initial clhoride efflux rates shown in Table 1 of the manuscript were calculated divinding the $\%$ of chloride effluxed $(\% \mathrm{Cl})$ at $\mathrm{t}=60 \mathrm{~s}$ by the time $(\mathrm{s})$.

\section{$\mathrm{NO}_{3} / \mathrm{Cl}$ exchange at $\mathrm{pH} 7.2$ both in and out of the vesicles}

- Intravesicular solution: $489 \mathrm{mM} \mathrm{NaCl}$, I.S. $500 \mathrm{mM}, \mathrm{NaH}_{2} \mathrm{PO}_{4} 5 \mathrm{mM}, \mathrm{pH} 7.2$.

- Extravesicular solution: $489 \mathrm{mM} \mathrm{NaNO}_{3}$, I.S. 500 mM, $\mathrm{NaH}_{2} \mathrm{PO}_{4} 5 \mathrm{mM}, \mathrm{pH} 7.2$.

- $t=0 \mathrm{~s}$ vesicles + buffer.

- $t=60 \mathrm{~s}$ anion carrier addition in DMSO solution.

- $\quad t=300 \mathrm{~s} 20 \mu \mathrm{L}$ Triton X (10\% v/v).

- Total time: until stable lecture after the detergent addition (30-60 s).

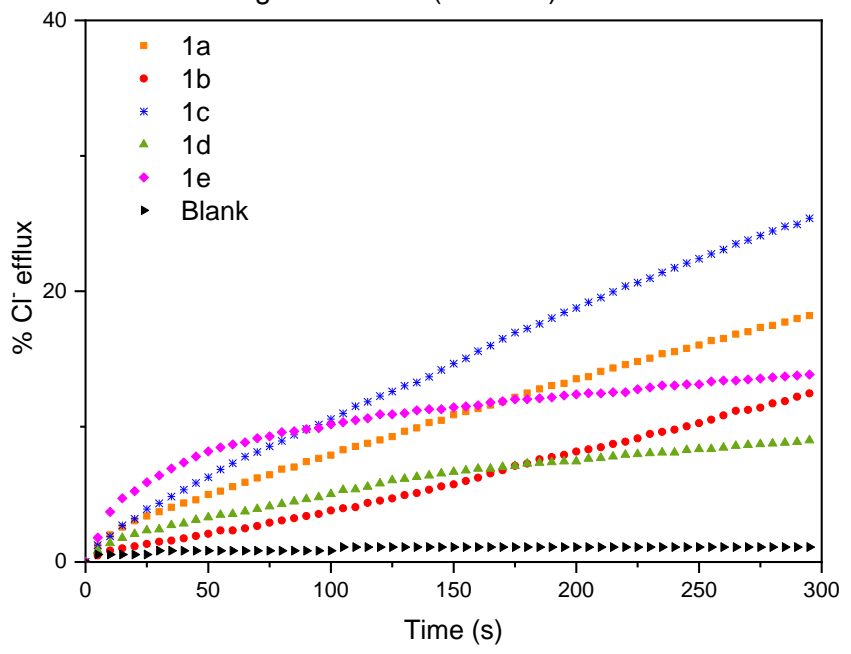

Figure S58. Anion transport activity of $1 \mathrm{a}-\mathrm{e}(50 \mu \mathrm{M}=10 \mathrm{~mol} \%)$ ISE experiment. $0.5 \mathrm{mM}$ POPC. Vesicles loaded with $489 \mathrm{mM} \mathrm{NaCl}$ (phosphate buffer $5 \mathrm{mM}$, pH 7.2) where suspended in $\mathrm{NaNO}_{3} 489 \mathrm{mM}$ (phosphate buffer $5 \mathrm{mM}, \mathrm{pH}$ 7.2). At $\mathrm{t}=300 \mathrm{~s}$ a pulse of detergent was added in order to release all chloride anions.

$\mathrm{NO}_{3}{ }^{-} / \mathrm{Cl}^{-}$exchange at $\mathrm{pH} 7.2$ outside and $\mathrm{pH} 6.2$ inside the vesicles

- $\quad$ Intravesicular solution: $489 \mathrm{mM} \mathrm{NaCl}$, I.S. $500 \mathrm{mM}, \mathrm{NaH}_{2} \mathrm{PO}_{4} 5 \mathrm{mM}, \mathrm{pH} 6.2$.

${ }^{16}$ L. A. Jowett, P. A. Gale, Supramol. Chem. 2019, 31, 297-312. 
- $\quad$ Extravesicular solution: $489 \mathrm{mM} \mathrm{NaNO}_{3}$, I.S. $500 \mathrm{mM}, \mathrm{NaH}_{2} \mathrm{PO}_{4} 5 \mathrm{mM}, \mathrm{pH} 7.2$.

- $t=0 \mathrm{~s}$ vesicles + buffer

- $t=60 \mathrm{~s}$ anion carrier addition in DMSO solution.

- $\mathrm{t}=300 \mathrm{~s} 20 \mu \mathrm{L}$ Triton X (10\% v/v).

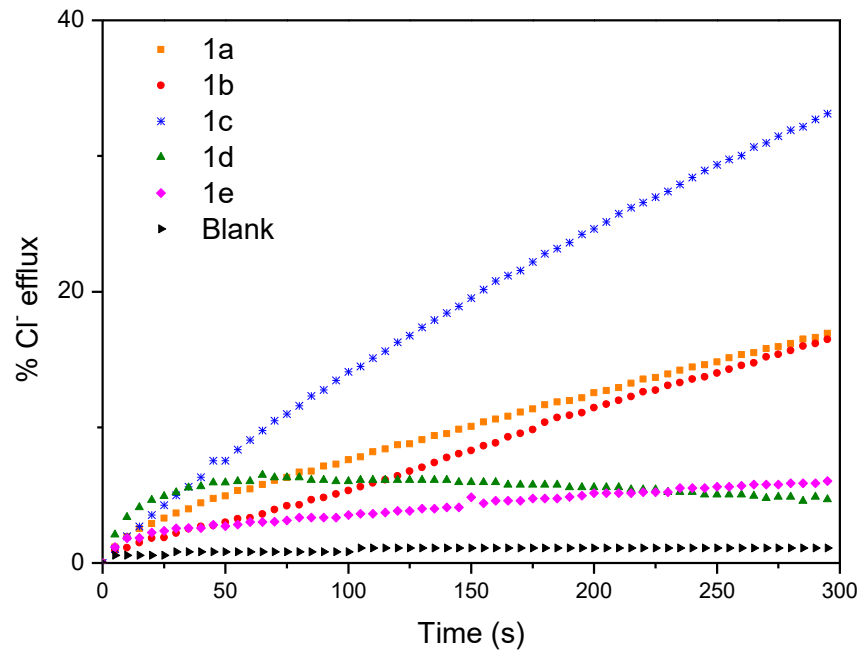

Figure S59. Anion transport activity of $1 \mathrm{a}-\mathrm{e}(50 \mu \mathrm{M}=10 \mathrm{~mol} \%)$ ISE experiment. $0.5 \mathrm{mM}$ POPC. Vesicles loaded with $489 \mathrm{mM} \mathrm{NaCl}$ (phosphate buffer $5 \mathrm{mM}$, pH 6.2) where suspended in $\mathrm{NaNO}_{3} 489 \mathrm{mM}$ (phosphate buffer $5 \mathrm{mM}, \mathrm{pH}$ 7.2). At $\mathrm{t}=300 \mathrm{~s}$ a pulse of detergent was added in order to release all chloride anions.

$\mathrm{NO}_{3} / \mathrm{Cl}^{-}$exchange at $\mathrm{pH} 6.2$ outside and 6.2 inside the vesicles

- Intravesicular solution: $489 \mathrm{mM} \mathrm{NaCl}$, I.S. $500 \mathrm{mM}, \mathrm{NaH}_{2} \mathrm{PO}_{4} 5 \mathrm{mM}, \mathrm{pH}$ 6.2.

- $\quad$ Extravesicular solution: $489 \mathrm{mM} \mathrm{NaNO}_{3}$, I.S. $500 \mathrm{mM}, \mathrm{NaH}_{2} \mathrm{PO}_{4} 5 \mathrm{mM}, \mathrm{pH} 7.2$.

- $t=0$ s vesicles + buffer.

- $t=60 \mathrm{~s}$ anion carrier addition in DMSO solution.

- $\mathrm{t}=300 \mathrm{~s} 20 \mu \mathrm{L}$ Triton $X(10 \% \mathrm{v} / \mathrm{v})$.

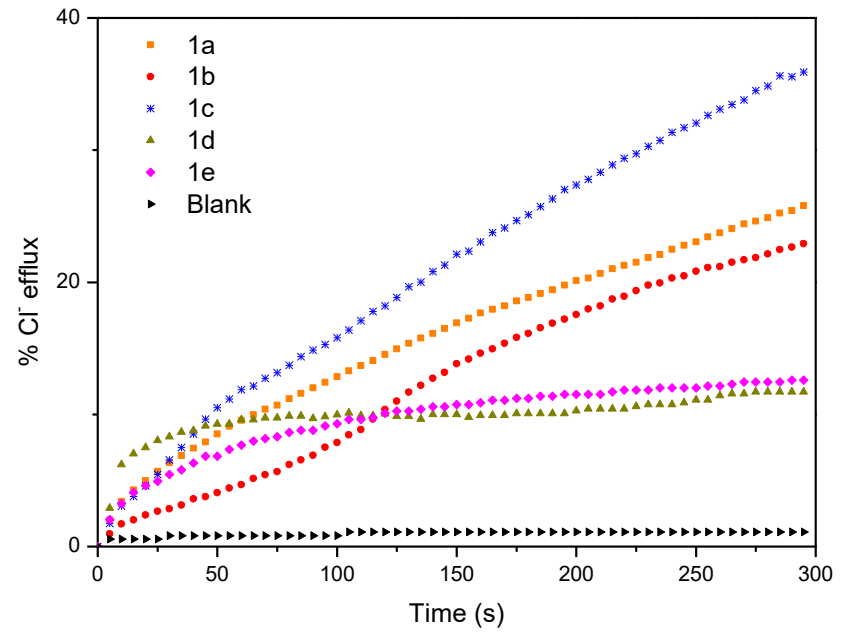

Figure S60. Anion transport activity of $1 \mathrm{a}-\mathrm{e}(50 \mu \mathrm{M}=10 \mathrm{~mol} \%)$ ISE experiment. $0.5 \mathrm{mM}$ POPC. Vesicles loaded with $489 \mathrm{mM} \mathrm{NaCl}$ (phosphate buffer $5 \mathrm{mM}$, pH 6.2) where suspended in $\mathrm{NaNO}_{3} 489 \mathrm{mM}$ (phosphate buffer $5 \mathrm{mM}, \mathrm{pH}$ 6.2). At $\mathrm{t}=300 \mathrm{~s}$ a pulse of detergent was added in order to release all chloride anions. 


\section{Fluorescence based transport assays.}

These assays are based on fluorophores whose fluorescence varies as a function of changes in different variables such as concentration (carboxyfluorescein), pH (HPTS) or the presence of some ions (lucigenin is selectively quenched by chloride). POPC and POPC : cholesterol (7:3) vesicles were prepared as previously described. The non-encapsulated rehydrating solution was removed by SEC, using as mobile phase the external buffer. The intra- and extravesicular compositions are outlined below. The total volume in the cuvettes was $2500 \mu \mathrm{L}$. Unless other specification, the anion carrier was added at $\mathrm{t}=60 \mathrm{~s}$ and fluorescence changes were monitored over time.

\section{Lucigenin based assays}

- $\quad$ Extravesicular solution: $102.2 \mathrm{mM} \mathrm{NaCl}$, I.S. $150 \mathrm{mM}, \mathrm{NaH}_{2} \mathrm{PO}_{4} 20 \mathrm{mM}, \mathrm{pH} 7.2$.

- $t=0 \mathrm{~s}$ vesicles + buffer.

- $\mathrm{t}=60 \mathrm{~s}$ anion carrier addition in $\mathrm{MeOH}$ solution.

- Total time $360 \mathrm{~s}$.

- $\quad \lambda_{\mathrm{exc}}=372 \mathrm{~nm} ; \lambda_{\mathrm{em}}=503 \mathrm{~nm}$.

Lucigenin is a bisacridinium salt whose fluorescence emission is quenched by halides. $\left(\mathrm{Ksv}, \mathrm{Cl}^{-}=390 \mathrm{M}^{1}\right) .{ }^{17}$ Based on these properties, lucigenin could be employed to monitor the chloride transport inside vesicles at $503 \mathrm{~nm}$ after exciting at $372 \mathrm{~nm}$. Data collected was represented as initial fluorescence divided by fluorescence vs time $\left(f_{0} / f\right)$.

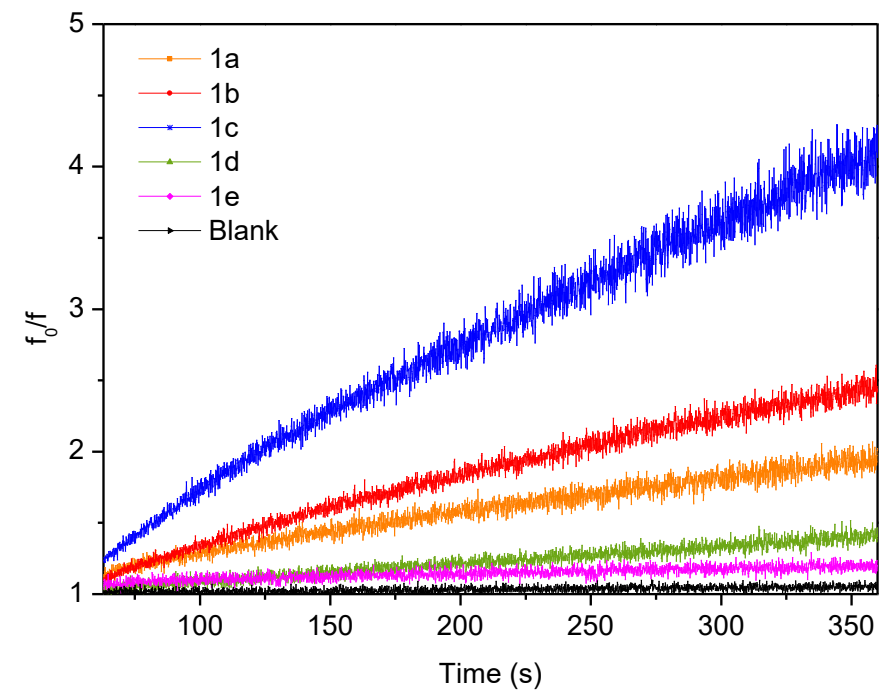

Figure S61. fo/f normalization of lucigenin fluorescence emission upon addition of cages 1a-e to POPC:Cholesterol (7:3) vesicles, 0.25 mM POPC. Vesicles contained $\mathrm{NaNO}_{3}\left(102.2 \mathrm{mM} \mathrm{NaNO}_{3}\right.$, I.S. $150 \mathrm{mM}, \mathrm{NaH}_{2} \mathrm{PO}_{4} 20 \mathrm{mM}$, pH 7.2; lucigenin $3 \mathrm{mM}$ ) were suspended in $\mathrm{NaCl}\left(102.2 \mathrm{mM} \mathrm{NaCl}, \mathrm{I} . \mathrm{S} .150 \mathrm{mM}, \mathrm{NaH}_{2} \mathrm{PO}_{4} 20\right.$ $\mathrm{mM}, \mathrm{pH}$ 7.2). At $\mathrm{t}=60 \mathrm{~s}$ the anion carrier was added $(10 \mathrm{~mol} \%$ carrier to lipid; $0.025 \mathrm{mM})$. Blank $(12.5 \mu \mathrm{L} \mathrm{MeOH})$. Each trace represents the average of at least three different trials, done with at least two different batches of vesicles.

\section{5(6)-carboxyfluorescein based assays}

- $\quad$ POPC vesicles $0.05 \mathrm{mM}$

- Intravesicular solution: $451 \mathrm{mM} \mathrm{NaCl}$, I.S. $500 \mathrm{mM}, \mathrm{NaH}_{2} \mathrm{PO}_{4} 20 \mathrm{mM}$, pH 7.2; carboxyfluorescein 50 mM.

- Extravesicular solution: $150 \mathrm{mM} \mathrm{Na}_{2} \mathrm{SO}_{4}$, I.S. $500 \mathrm{mM}, \mathrm{NaH}_{2} \mathrm{PO}_{4} 20 \mathrm{mM}, \mathrm{pH} 7.2$

- $t=0 \mathrm{~s}$ vesicles + buffer

- $t=60 \mathrm{~s}$ anion carrier addition in DMSO solution

- $t=360 \mathrm{~s}$ detergent. The fluorescence was recorded 2 more minutes

- $\quad$ Total time $=480 \mathrm{~s}$

- $\lambda_{\mathrm{exc}}=490 \mathrm{~nm} ; \lambda_{\mathrm{em}}=520 \mathrm{~nm}$

Data processed:

The following equation is applied to the obtained data.

$$
C F \text { Leakage }=\left[\frac{I_{t}-I_{0}}{I_{\max }-I_{0}}\right]_{\lambda=520 \mathrm{~nm}}
$$

- $\quad \mathrm{I}_{\mathrm{t}} \rightarrow$ fluorescence intensity at time $\mathrm{t}$.

${ }^{17}$ a) J. Biwersi, B. Tulk, A. S. Verkman, Anal. Biochem., 1994, 219, 139-143; b) C. Huber, K. Fähnrich, C. Krause and T, Werner, J. Photochem. Photobiol., 1999, $128,111-120$ 
- $\quad \mathrm{I}_{0} \rightarrow$ fluorescence intensity at time $0 \mathrm{~s}$.

- $\quad I_{\max } \rightarrow$ maximum fluorescence intensity observed after addition of detergent.

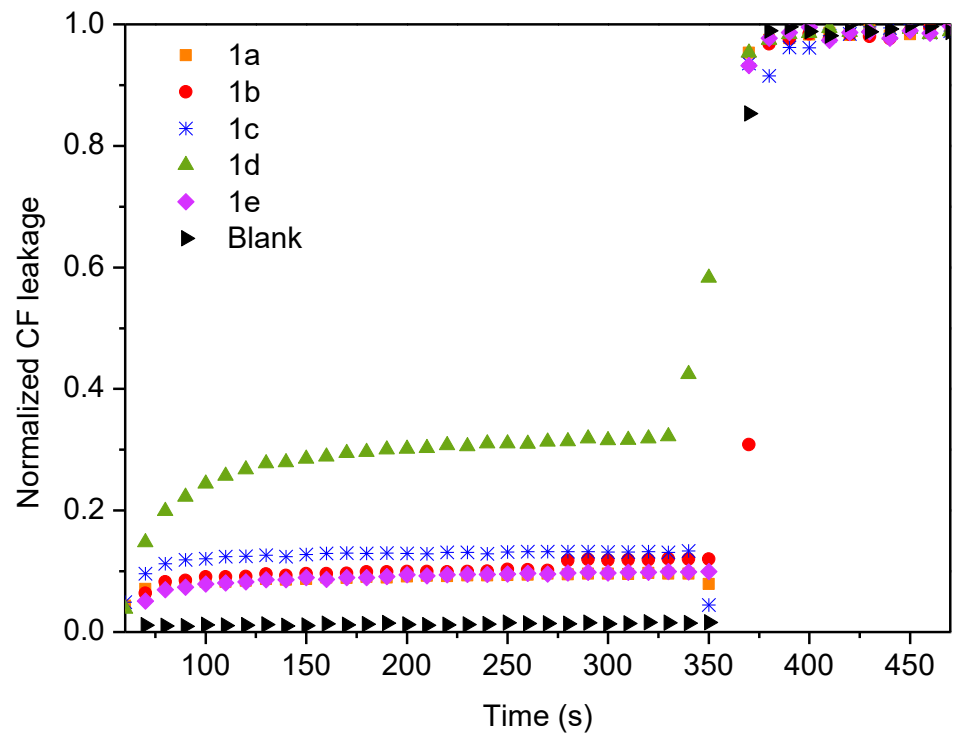

Figure S62. Carboxyfluorescein leakage upon addition of 1a-e to POPC vesicles, $0.05 \mathrm{mM}$. Vesicles contained $\mathrm{NaCl}\left(451 \mathrm{mM}\right.$, buffered with $\mathrm{NaH}_{2} \mathrm{PO}{ }_{4} 20 \mathrm{mM}$ to $\mathrm{pH}$ 7.2, I.S. $500 \mathrm{mM}$ and $50 \mathrm{mM} \mathrm{CF})$ were suspended in $\mathrm{Na}_{2} \mathrm{SO}_{4}\left(150 \mathrm{mM}\right.$, buffered with $\mathrm{NaH}_{2} \mathrm{PO}_{4} 20 \mathrm{mM}$ to $\mathrm{pH} 7.2$, I.S. $\left.500 \mathrm{mM}\right)$. At $\mathrm{t}=60 \mathrm{~s}$ addition of the anion carrier (10 mol\% carrier to lipid). At $t=360 \mathrm{~s}$ addition of $20 \mu \mathrm{L}$ of detergent. blank (12.5 $\mu \mathrm{L} \mathrm{DMSO}$ ). Each trace represents the average of at least three different trials, done with at least two different batches of vesicles

\section{HPTS based assays}

HPTS based assay with $\mathrm{NaNO}_{3}$ :

- $\quad$ POPC:cholesterol (7:3) vesicles $0.5 \mathrm{mM}$ in POPC

- Intravesicular solution: $126.2 \mathrm{mM} \mathrm{NaNO}_{3}$, I.S. $150 \mathrm{mM}, \mathrm{NaH}_{2} \mathrm{PO}_{4} 10 \mathrm{mM}$, pH 6.5; HPTS $10 \mu \mathrm{M}$

- $\quad$ Extravesicular solution: $126.2 \mathrm{mM} \mathrm{NaNO}_{3}$, I.S. $150 \mathrm{mM}, \mathrm{NaH}_{2} \mathrm{PO}_{4} 10 \mathrm{mM}, \mathrm{pH} 7.5$

- $t=0$ s vesicles + buffer

- $t=60 \mathrm{~s}$ anion carrier addition in DMSO solution.

- $\quad$ Total time $360 \mathrm{~s}$

- $\lambda_{\mathrm{exc}}=403 \mathrm{~nm}$ and $460 \mathrm{~nm} ; \lambda_{\mathrm{em}}=510 \mathrm{~nm}$

HPTS based assay with $\mathrm{NaCl}$ :

- $\quad$ POPC:cholesterol (7:3) vesicles $0.5 \mathrm{mM}$ in POPC

- Intravesicular solution: $126.2 \mathrm{mM} \mathrm{NaCl}$, I.S. $150 \mathrm{mM}, \mathrm{NaH}_{2} \mathrm{PO}_{4} 10 \mathrm{mM}$, pH 6.5; HPTS $10 \mu \mathrm{M}$

- Extravesicular solution: $126.2 \mathrm{mM} \mathrm{NaCl}$, I.S. $150 \mathrm{mM}, \mathrm{NaH}_{2} \mathrm{PO}_{4} 10 \mathrm{mM}, \mathrm{pH} 7.5$

- $t=0 \mathrm{~s}$ vesicles + buffer

- $t=60 \mathrm{~s}$ anion carrier addition in DMSO solution.

- Total time $360 \mathrm{~s}$

- $\lambda_{\mathrm{exc}}=403 \mathrm{~nm}$ and $460 \mathrm{~nm} ; \lambda_{\mathrm{em}}=510 \mathrm{~nm}$

The relationship between the fluorescence intensity at $510 \mathrm{~nm}$ when the sample is excited at both 460 and $403 \mathrm{~nm}$ allows to determine the internal $\mathrm{pH}$ at each time:

$$
\frac{\text { Fi em } 510 \mathrm{~nm}(\lambda \text { ex } 460 \mathrm{~nm})}{\text { Fi em } 510 \mathrm{~nm}(\lambda \text { ex } 403 \mathrm{~nm})}
$$

A calibration curve for determining the actual $\mathrm{pH}$ value as function of the ratiometric emission of HPTS was carried out using $15 \mathrm{nM}$ HPTS in the phosphate buffer solutions used in the measurements (with $\mathrm{NaNO}_{3}$ and with $\mathrm{NaCl}$ ) and adding consecutive aliquots of $\mathrm{NaOH} 0.5 \mathrm{M}$ to the solution to raise the $\mathrm{pH}$ from 5.5 to 9.5. After each addition the fluorescence rate was read. The representation of the emission ration $\left(\mathrm{I}_{406} / \mathrm{I}_{403}\right)$ vs the $\mathrm{pH}$ was adjusted to a S-Logistic model ${ }^{18}$. 


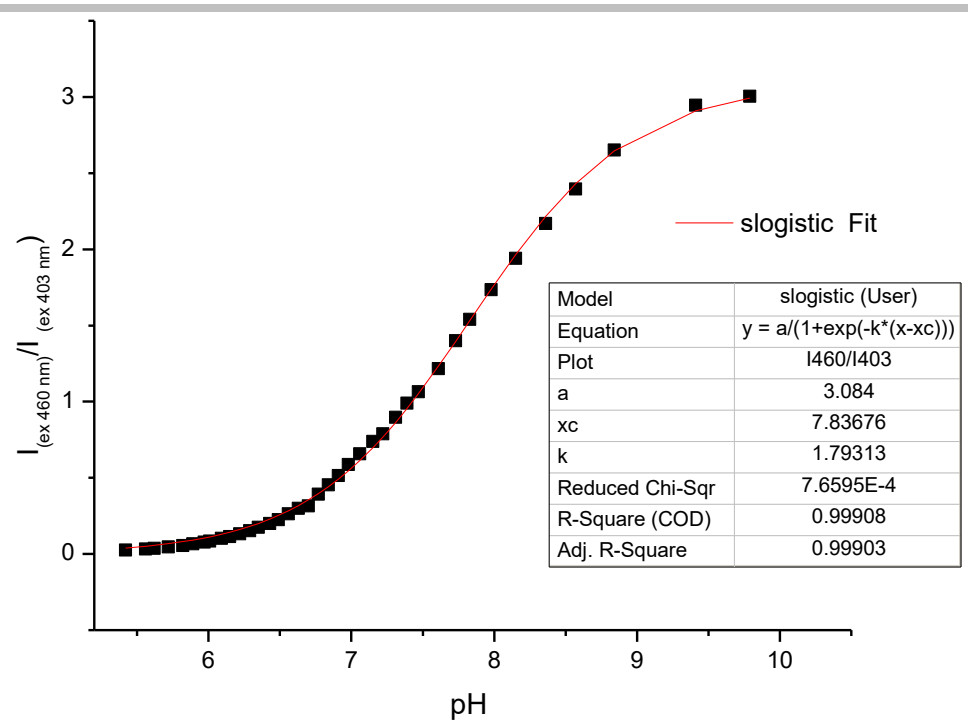

Figure S63. HPTS calibration s-logistic1 model (126 mM NaCl,10 mM buffer phosphate).

The conversion of fluorescence data into $\mathrm{pH}$ was done with the corresponding S-Logistic1 model obtained from the calibration curve at the experimental condition.

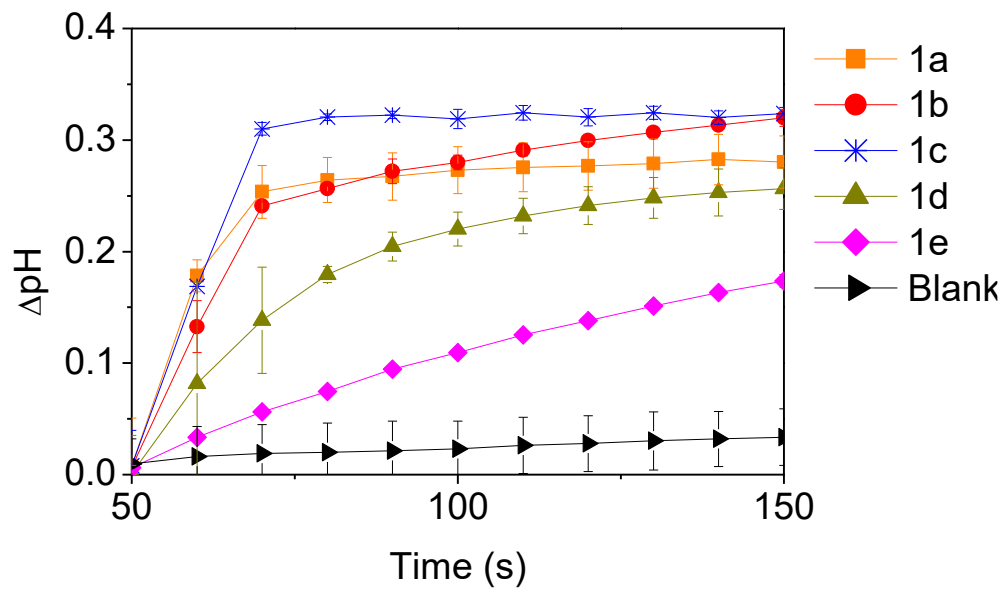

Figure S64. Variation of pH upon addition of compounds 1a-e (10 mol\%) to POPC:cholesterol (7:3) vesicles, $0.5 \mathrm{mM} \mathrm{POPC.} \mathrm{Vesicles} \mathrm{contained} \mathrm{NaCl} \mathrm{(126.25} \mathrm{mM}$ $\mathrm{NaCl}, 10 \mathrm{mM}$ buffer phosphate pH 6.5, I.S. $150 \mathrm{mM}$ and HPTS $10 \mu \mathrm{M})$ were suspended in $\mathrm{NaCl}(126.25 \mathrm{mM} \mathrm{NaCl}, 10 \mathrm{mM}$ buffer phosphate and I.S. $150 \mathrm{mM})$. At $\mathrm{t}$ $=60 \mathrm{~s}$ addition of the anion carrier. (blank (12.5 $\mu \mathrm{L} \mathrm{DMSO})$ ). Each trace represents the average of at least three different trials from at least two different batches of vesicles. 


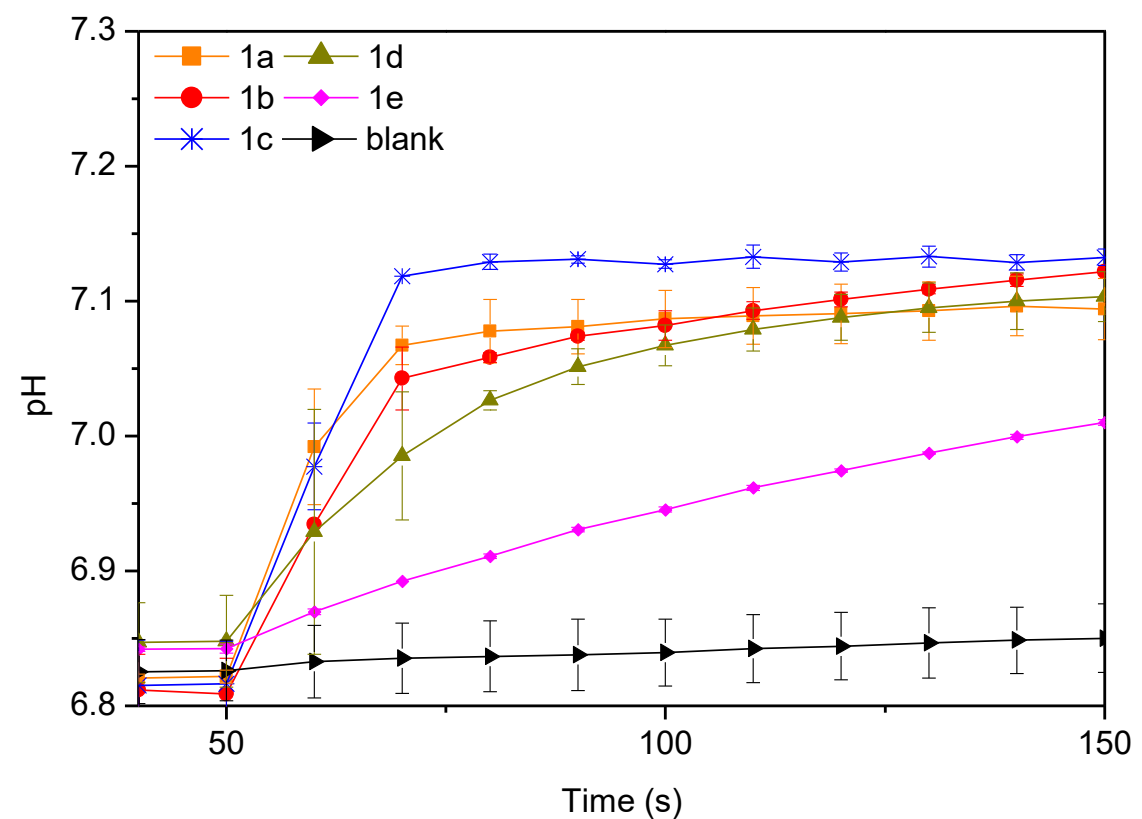

Figure S65. Plot of the $\mathrm{pH}$ value upon addition of compounds 1a-e (10 mol\%) to POPC:cholesterol (7:3) vesicles, $0.5 \mathrm{mM}$ POPC. Vesicles contained NaCl (126.25 $\mathrm{mM} \mathrm{NaCl}, 10 \mathrm{mM}$ buffer phosphate, I.S. $150 \mathrm{mM}$ and HPTS $10 \mu \mathrm{M})$ were suspended in $\mathrm{NaCl}(126.25 \mathrm{mM} \mathrm{NaCl}, 10 \mathrm{mM}$ buffer phosphate and I.S. $150 \mathrm{mM})$. At t $=$ $60 \mathrm{~s}$ addition of the anion carrier (blank (12.5 $\mu \mathrm{L}$ DMSO)). Each trace represents the average of at least three different trials from at least two different batches of vesicles. 
(FPhe) - $\mathrm{CH}-\mathrm{CH}-\mathrm{CF}$

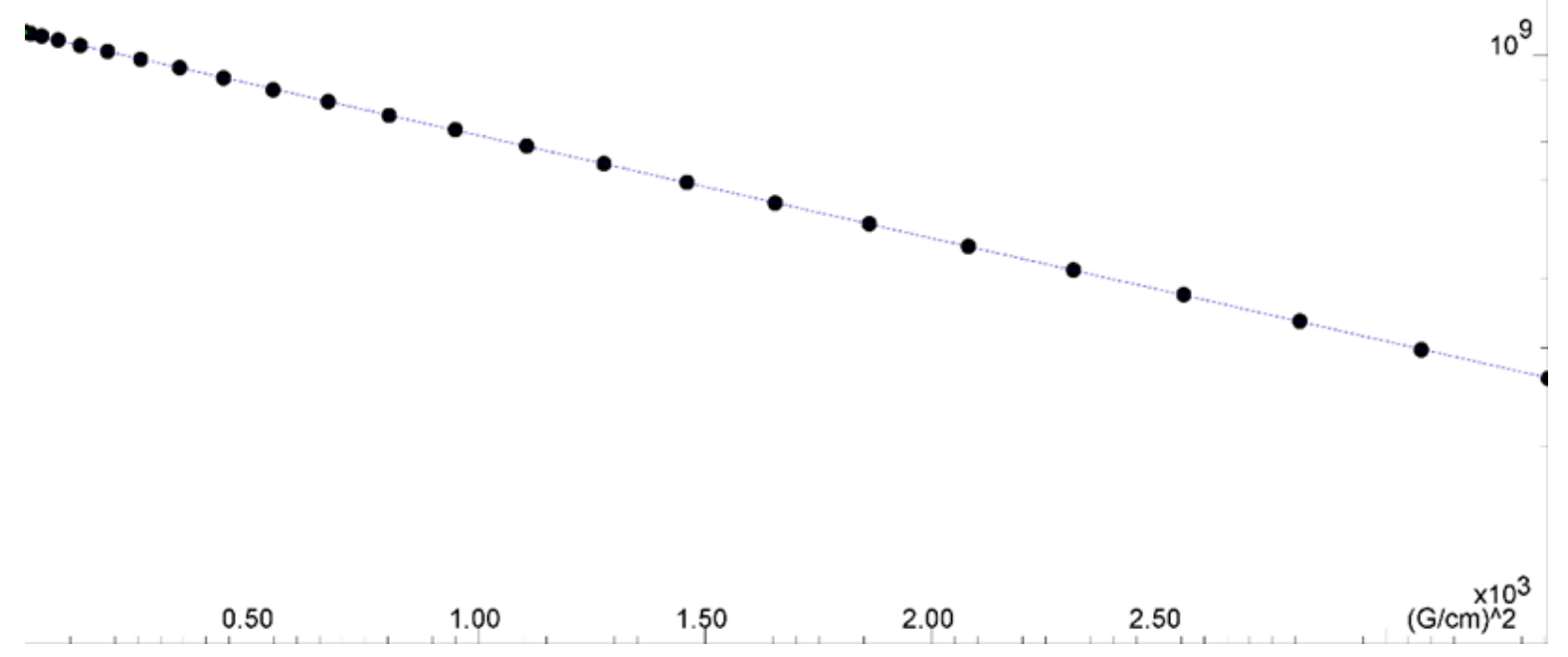

(FPhe) - $\mathrm{CH}-\mathrm{CH}-\mathrm{CF}$

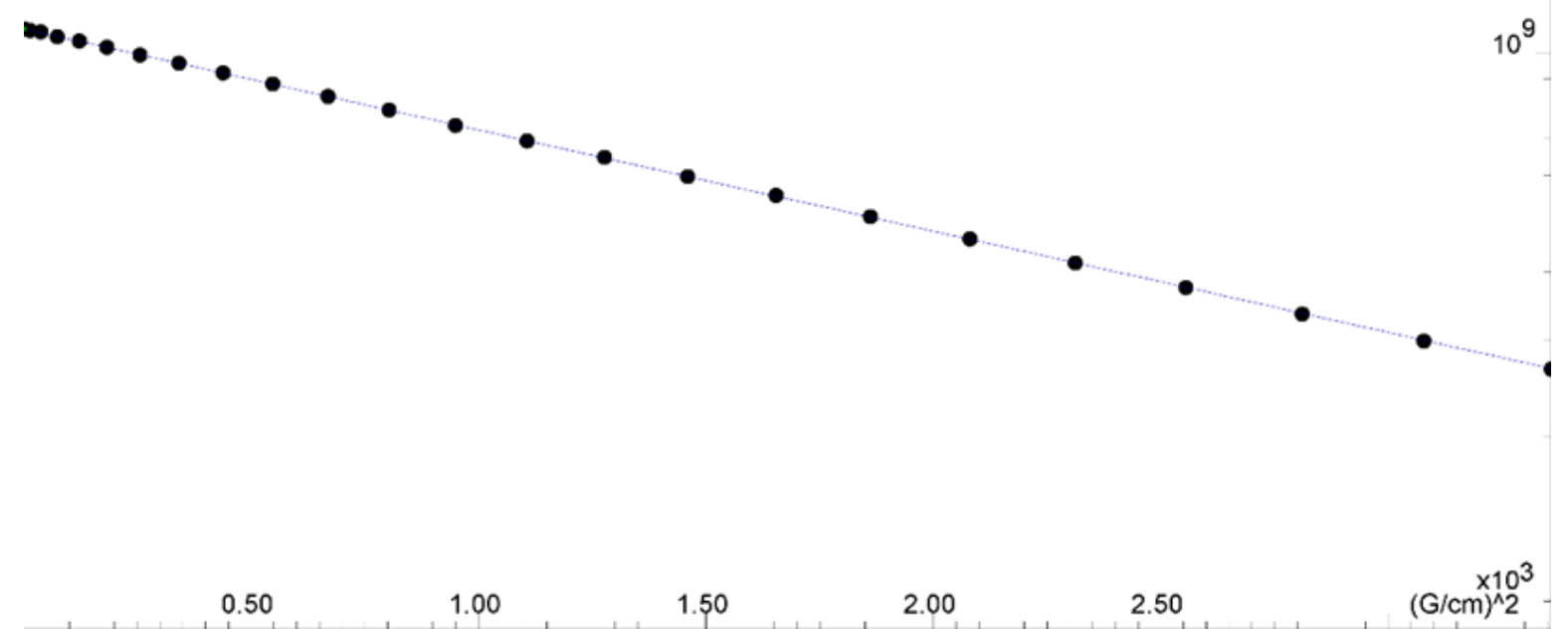

Figure S66. Representative fittings (In(I/I0) versus g2, Eq.1) for diffusion coefficients measurements (sample $1.0 \mathrm{mM}$ cage 1c in DMSO-d6/5 mM TBACl/10 mM TFA-d1) obtained using Dynamics Center software from Bruker 
Table S8. Translational diffusion coefficient measured by NMR spectroscopy for 1c samples in DMSO-d6 or DPC-d38 micelles at different pH values and salt concentration.

\begin{tabular}{|c|c|c|}
\hline & $\mathrm{D}\left(10^{-11} \mathrm{~m}^{2} \cdot \mathrm{s}^{-1}\right)$ & $\operatorname{SD}\left(10^{-11} \mathrm{~m}^{2} \cdot \mathrm{s}^{-1}\right)$ \\
\hline \multicolumn{3}{|c|}{$0.4 \mathrm{mM}$ 1c DMSO- $d 6 / 5 \mathrm{mM}$ TBACl/10 mM TFA- $d 1$} \\
\hline 2,6- $\mathrm{H}$ Aromatic region & 14.98 & 0.003095 \\
\hline 3,5- $\mathrm{H}$ Aromatic region & 15.08 & 0.002951 \\
\hline DMSO-d6 & 76.10 & 0.010090 \\
\hline \multicolumn{3}{|l|}{$0.4 \mathrm{mM} 1 \mathrm{c}$ DMSO-d6 } \\
\hline 2,6- $\mathrm{H}$ Aromatic region & 18.53 & 0.002400 \\
\hline 3,5- $\mathrm{H}$ Aromatic region & 18.32 & 0.002372 \\
\hline $\mathrm{CH}_{3}$ & 18.60 & 0.002403 \\
\hline DMSO-d6 & 74.62 & 0.008677 \\
\hline \multicolumn{3}{|c|}{$0.4 \mathrm{mM} 1 \mathrm{c}: 25 \mathrm{mM}$ DPC $\left(\mathrm{D}_{2} \mathrm{O}, \mathrm{pH} 2.6\right)$} \\
\hline 2,6- $\mathrm{H}$ Aromatic region & 8.824 & 0.000525 \\
\hline 3,5- $\mathrm{H}$ Aromatic region & 8.856 & 0.000482 \\
\hline $\mathrm{CH}_{3}$ & 8.936 & 0.000458 \\
\hline $\mathrm{DPC} \mathrm{CH}$ & n.m. (broad) & n.m. (broad) \\
\hline $\mathrm{DPC} \mathrm{CH} \mathrm{CH}_{2}$ & 11.113 & 0.013930 \\
\hline \multicolumn{3}{|c|}{$0.4 \mathrm{mM} 1 \mathrm{c}: 25 \mathrm{mM}$ DPC $\left(\mathrm{D}_{2} \mathrm{O}, 150 \mathrm{mM} \mathrm{NaCl}, \mathrm{pH} 2.6\right)$} \\
\hline 2,6-H Aromatic region & 8.810 & 0.001428 \\
\hline 3,5- $\mathrm{H}$ Aromatic region & 8.870 & 0.001054 \\
\hline $\mathrm{CH}_{3}$ & 8.867 & 0.001075 \\
\hline $\mathrm{DPC} \mathrm{CH}_{3}$ & n.m. (broad) & n.m. (broad) \\
\hline $\mathrm{DPC} \mathrm{CH} 2$ & 11.160 & 0.000333 \\
\hline \multicolumn{3}{|c|}{$0.4 \mathrm{mM} 1 \mathrm{c}: 25 \mathrm{mM}$ DPC $\left(\mathrm{D}_{2} \mathrm{O}, \mathrm{pH} 7.1\right)$} \\
\hline 2,6-H Aromatic region & 8.844 & 0.000432 \\
\hline 3,5- $\mathrm{H}$ Aromatic region & 8.914 & 0.000313 \\
\hline $\mathrm{CH}_{3}$ & 8.917 & 0.000294 \\
\hline $\mathrm{DPC} \mathrm{CH}$ & 10.903 & 0.001280 \\
\hline $\mathrm{DPC} \mathrm{CH}$ & 12.590 & 0.001531 \\
\hline \multicolumn{3}{|c|}{0.4 mM 1c:25 mM DPC ( $\left.\mathrm{D}_{2} \mathrm{O}, 150 \mathrm{mM} \mathrm{NaCl}, \mathrm{pH} 7.1\right)$} \\
\hline 2,6- $\mathrm{H}$ Aromatic region & 8.751 & 0.009715 \\
\hline 3,5- $\mathrm{H}$ Aromatic region & 8.808 & 0.007750 \\
\hline $\mathrm{CH}_{3}$ & 8.743 & 0.006564 \\
\hline $\mathrm{DPC} \mathrm{CH}$ & 10.680 & 0.003462 \\
\hline $\mathrm{DPC} \mathrm{CH} \mathrm{CH}_{2}$ & 11.500 & 0.003900 \\
\hline
\end{tabular}



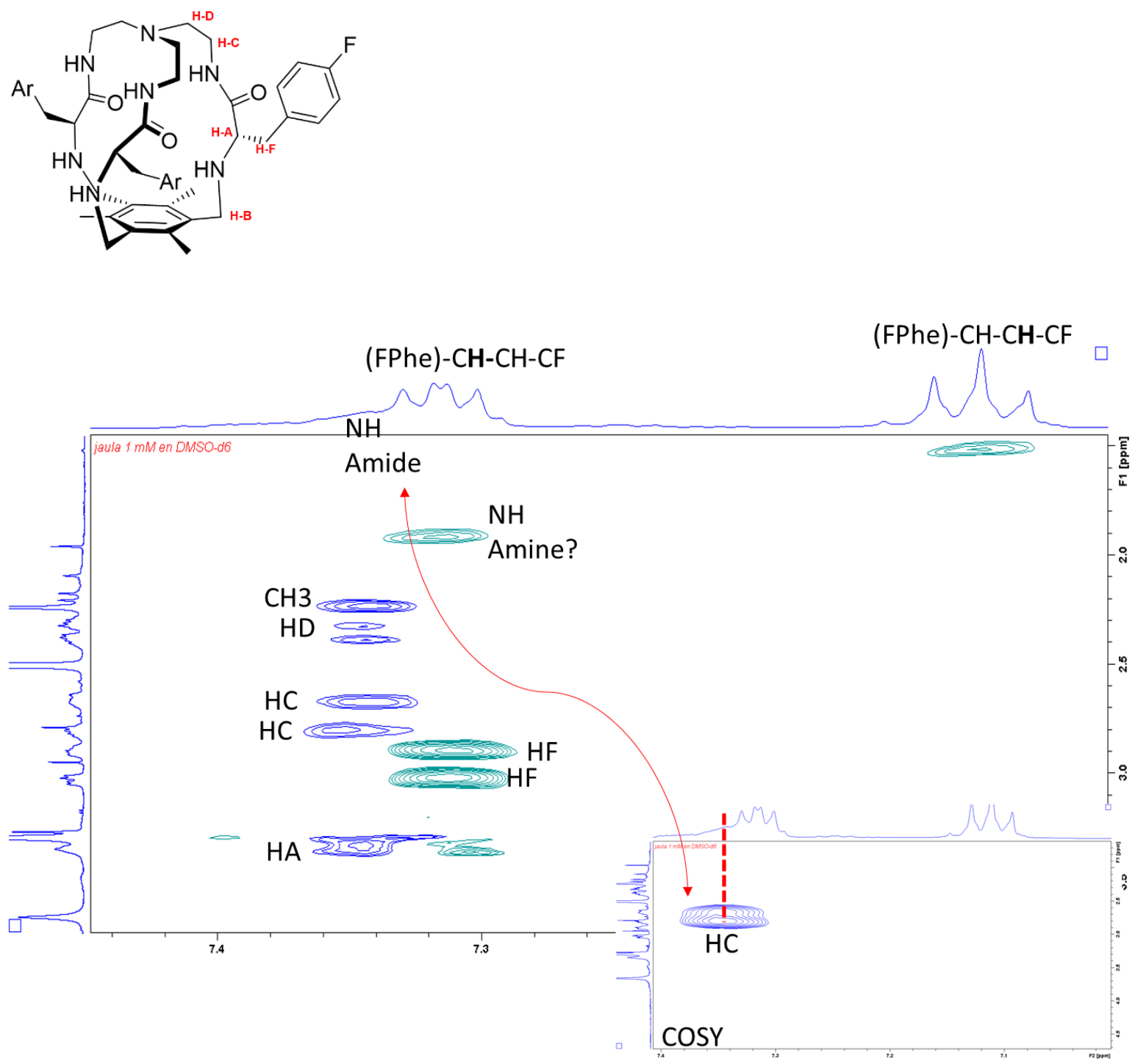

Figure S67. Part of the $2 \mathrm{D}{ }^{1} \mathrm{H}-{ }^{1} \mathrm{H}$ NOESY spectrum (250 ms mixing time, pulse sequence noesygpphzs) of $1 \mathrm{mM} 1 \mathrm{c}$ cage in DMSO-d6 with NOE's assignments The inset shows the ${ }^{1} \mathrm{H}-{ }^{1} \mathrm{H}$ COSY crosspeak between the cage amide and $\mathrm{H}-\mathrm{C}$ proton. 

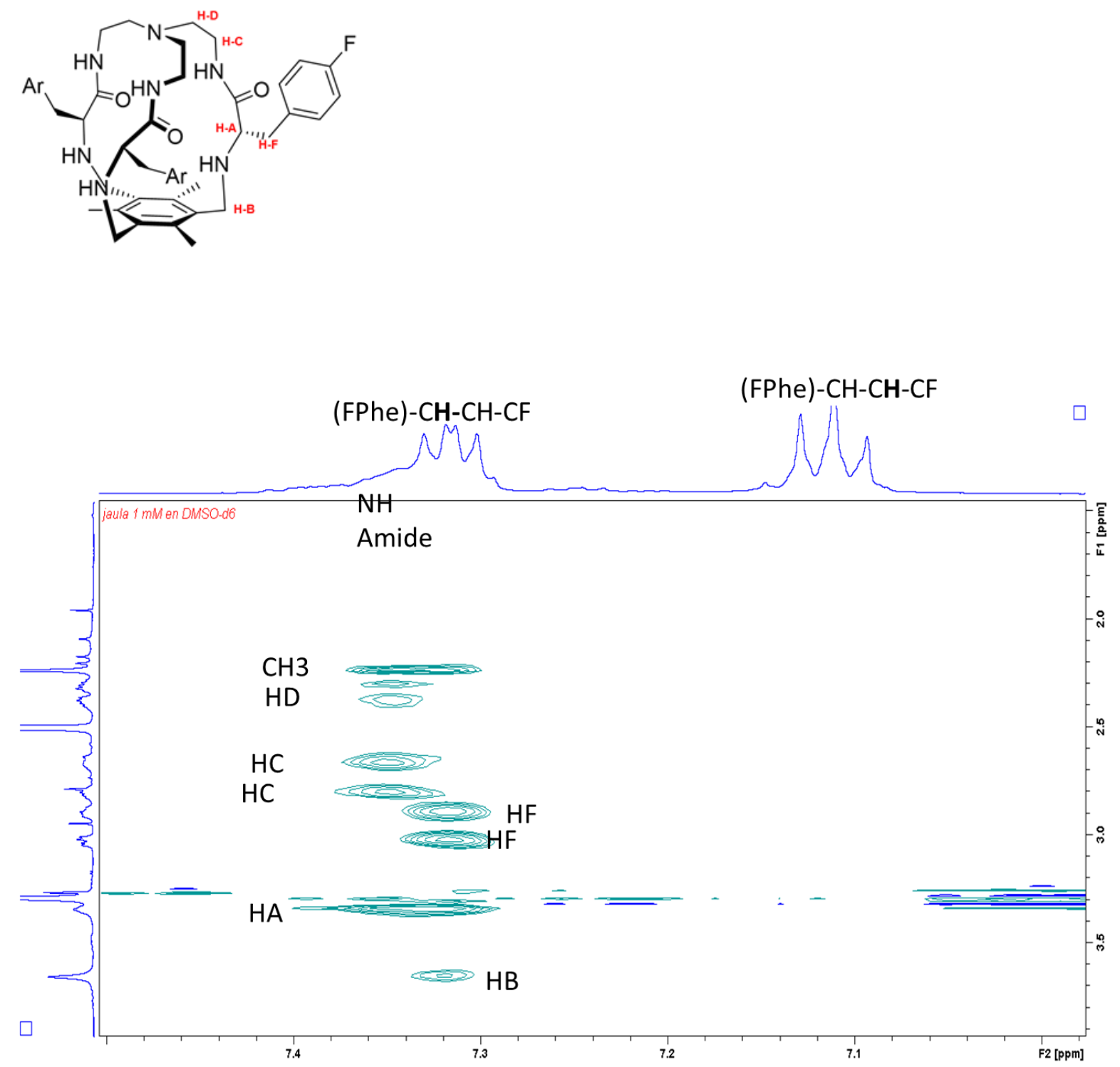

Figure S68. Part of the 2D ${ }^{1} \mathrm{H}-{ }^{1} \mathrm{H}$ EASY-ROESY spectrum (50 ms mixing time, pulse sequence roesyadjsphpr) of $1 \mathrm{mM} 1 \mathrm{c}$ in DMSO-d6 with ROE's assignments 

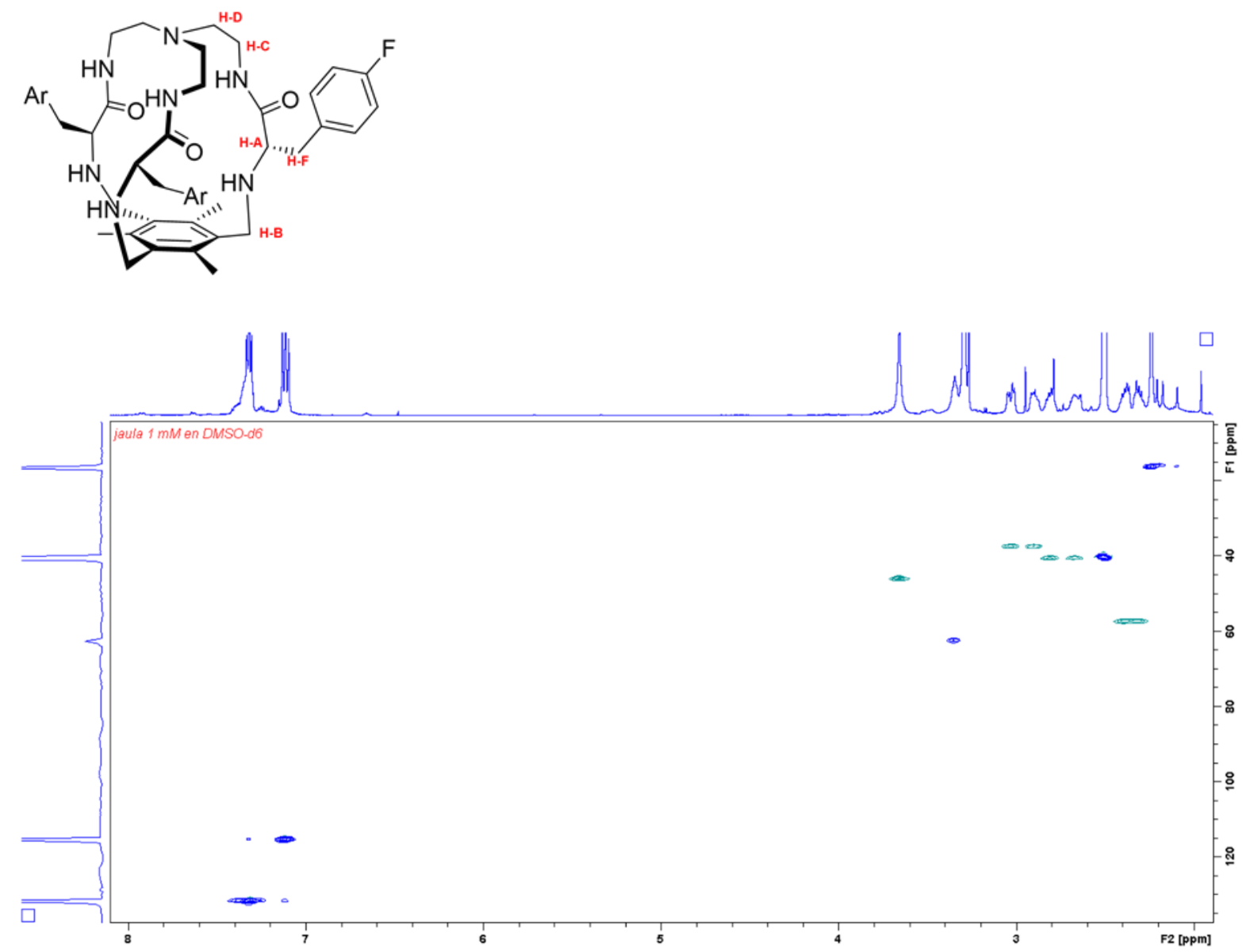

Figure S69. 2D ${ }^{1} \mathrm{H}-{ }^{13} \mathrm{C}$ HSQC spectrum (pulse sequence hsqcedetgpsisp2.3) of $1 \mathrm{mM} \mathrm{1c}$ in DMSO-d6. 

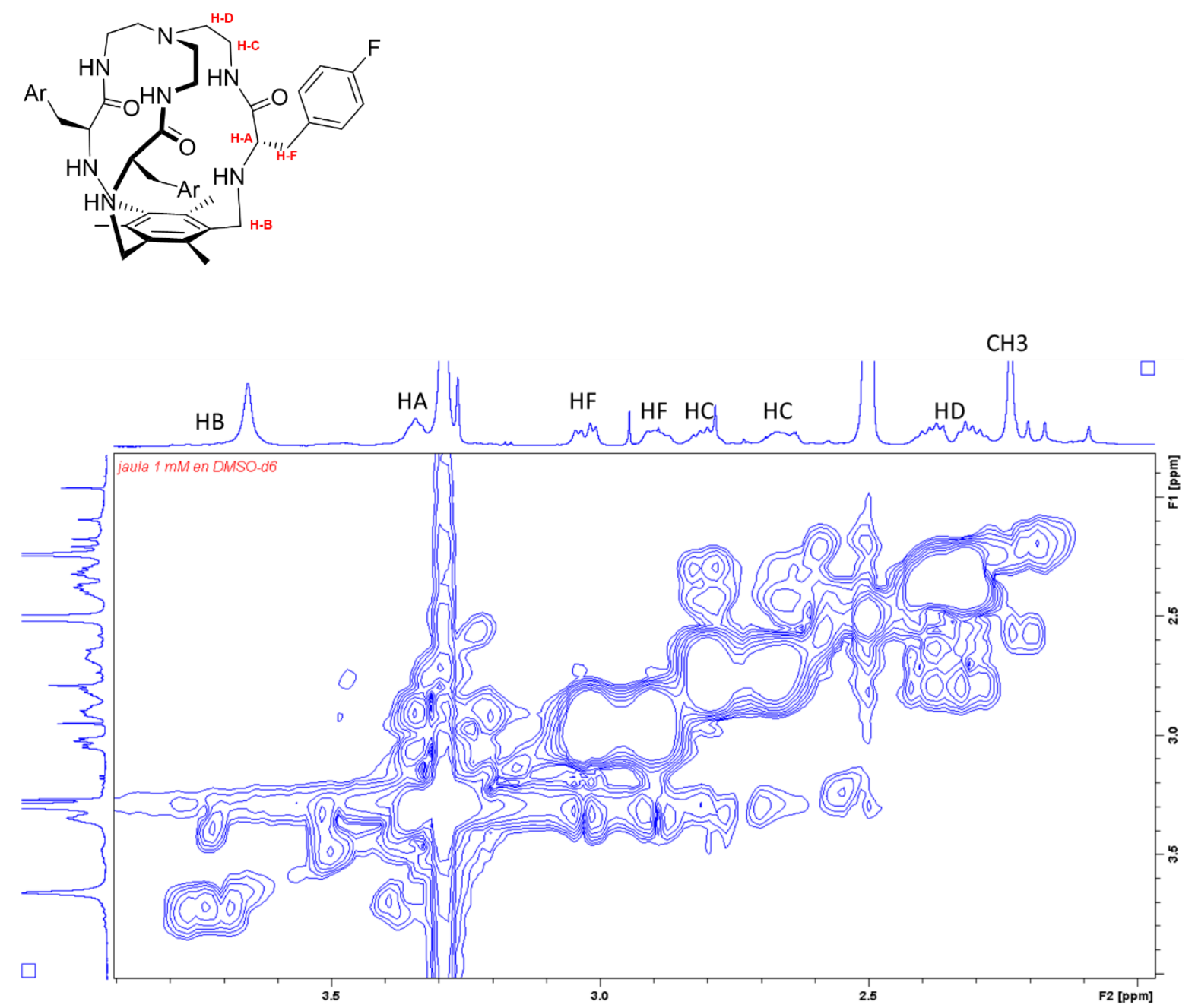

Figure S70. Part of the $2 \mathrm{D}^{1} \mathrm{H}-{ }^{-1} \mathrm{H}$ COSY spectrum (pulse sequence cosygpmfaf) of $1 \mathrm{mM} 1 \mathrm{c}$ cage in DMSO-d6. 


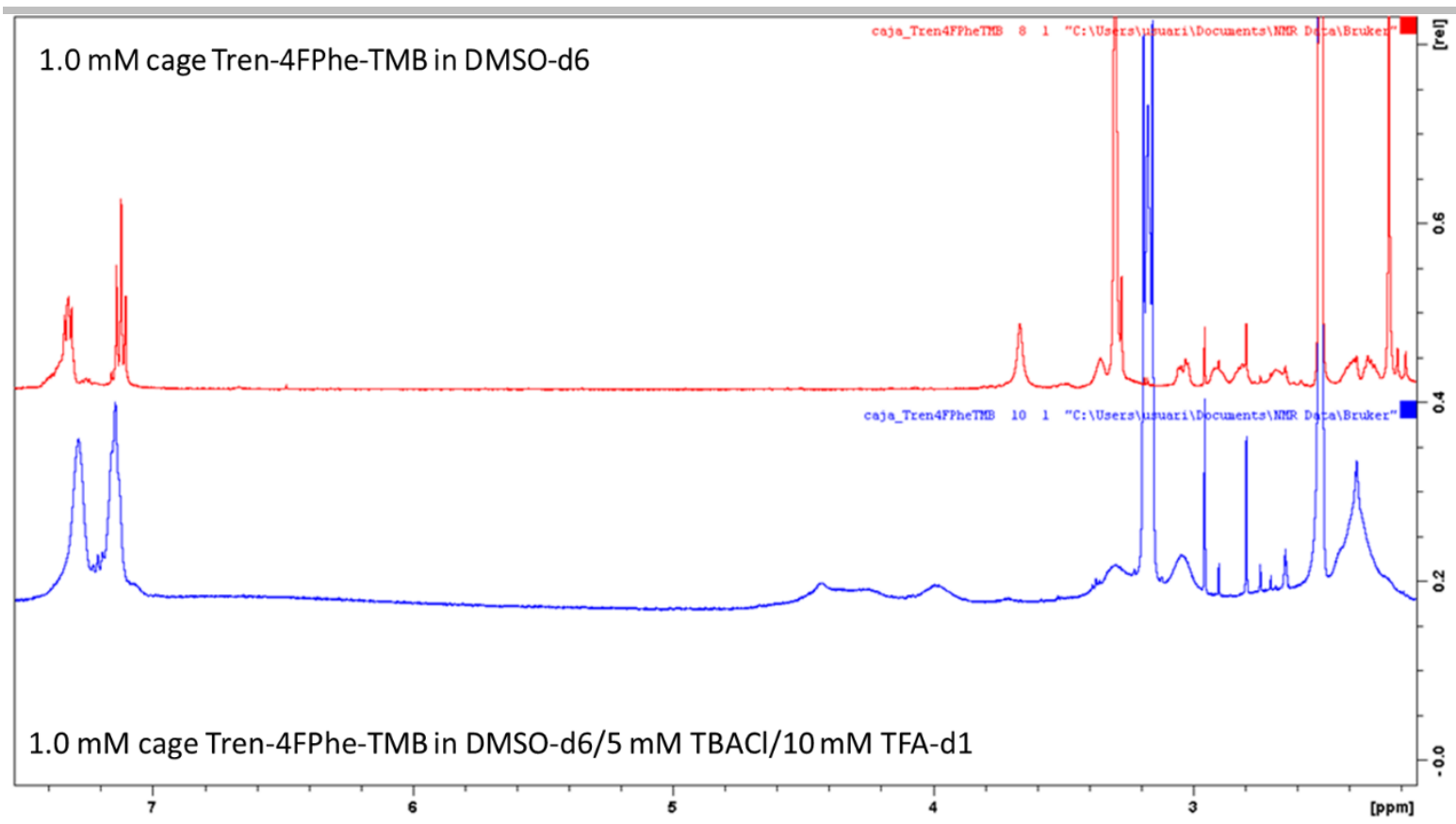

Figure S71. A comparison of the ${ }^{1} \mathrm{H}$ spectra of $1 \mathrm{mM} 1 \mathrm{c}$ non-protonated cage in DMSO-d6 (red spectrum) and protonated in presence of chloride (blue spectrum).

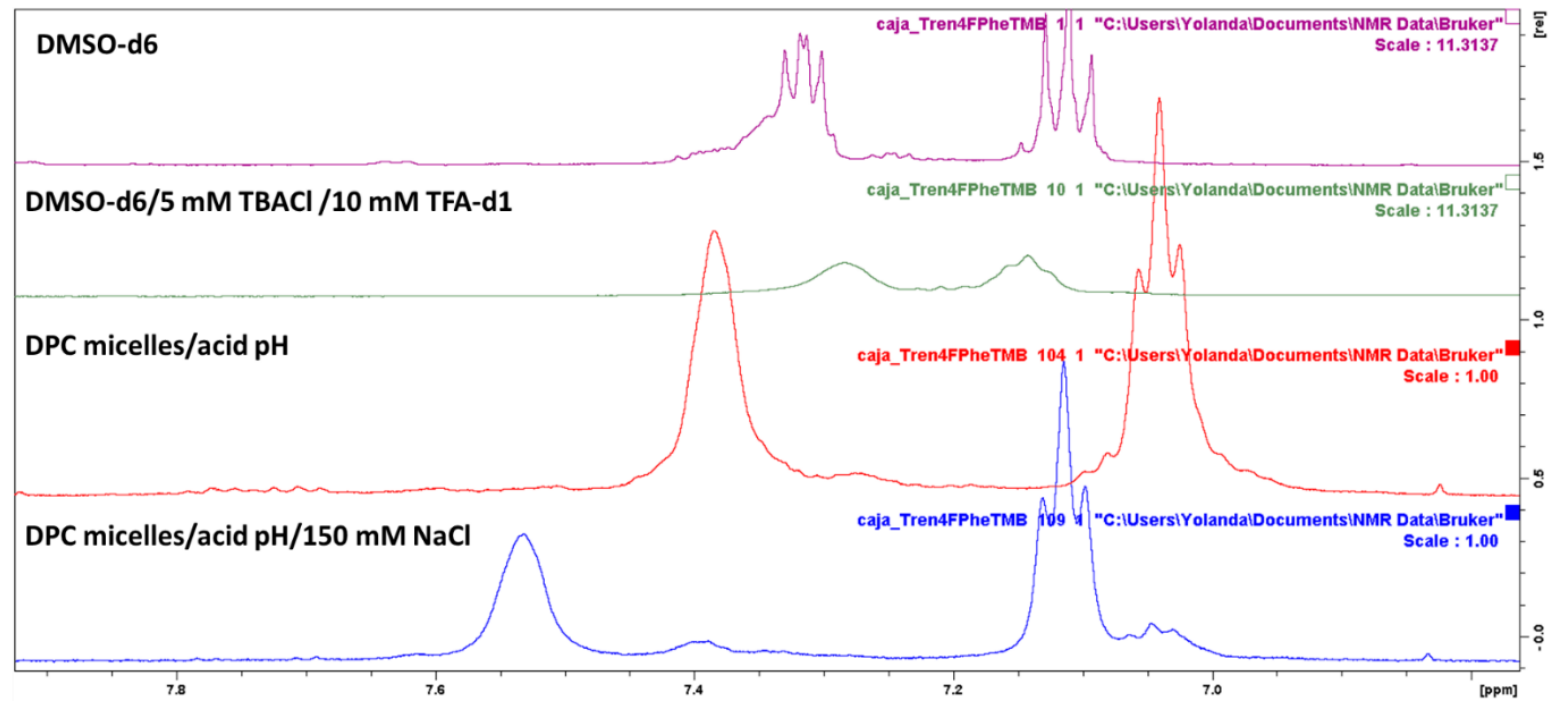

Figure S72. A comparison of the aromatic region of ${ }^{1} \mathrm{H}$ spectra of $1 \mathrm{c}$ in different solvent conditions $\left(1 \mathrm{mM}\right.$ in DMSO-d6 and $0.4 \mathrm{mM}$ in DPC/ $\left.{ }_{2} \mathrm{O}\right)$ 


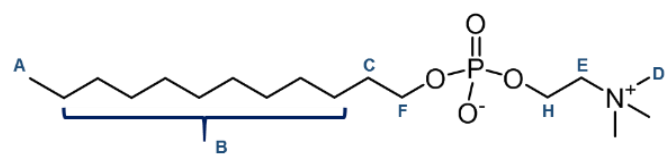

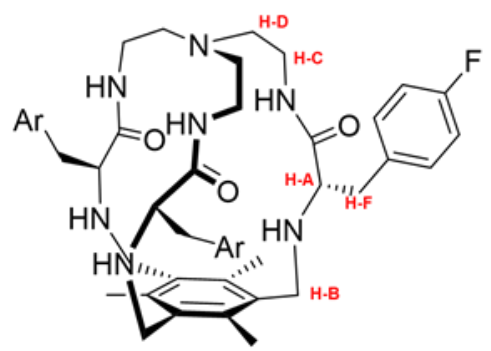

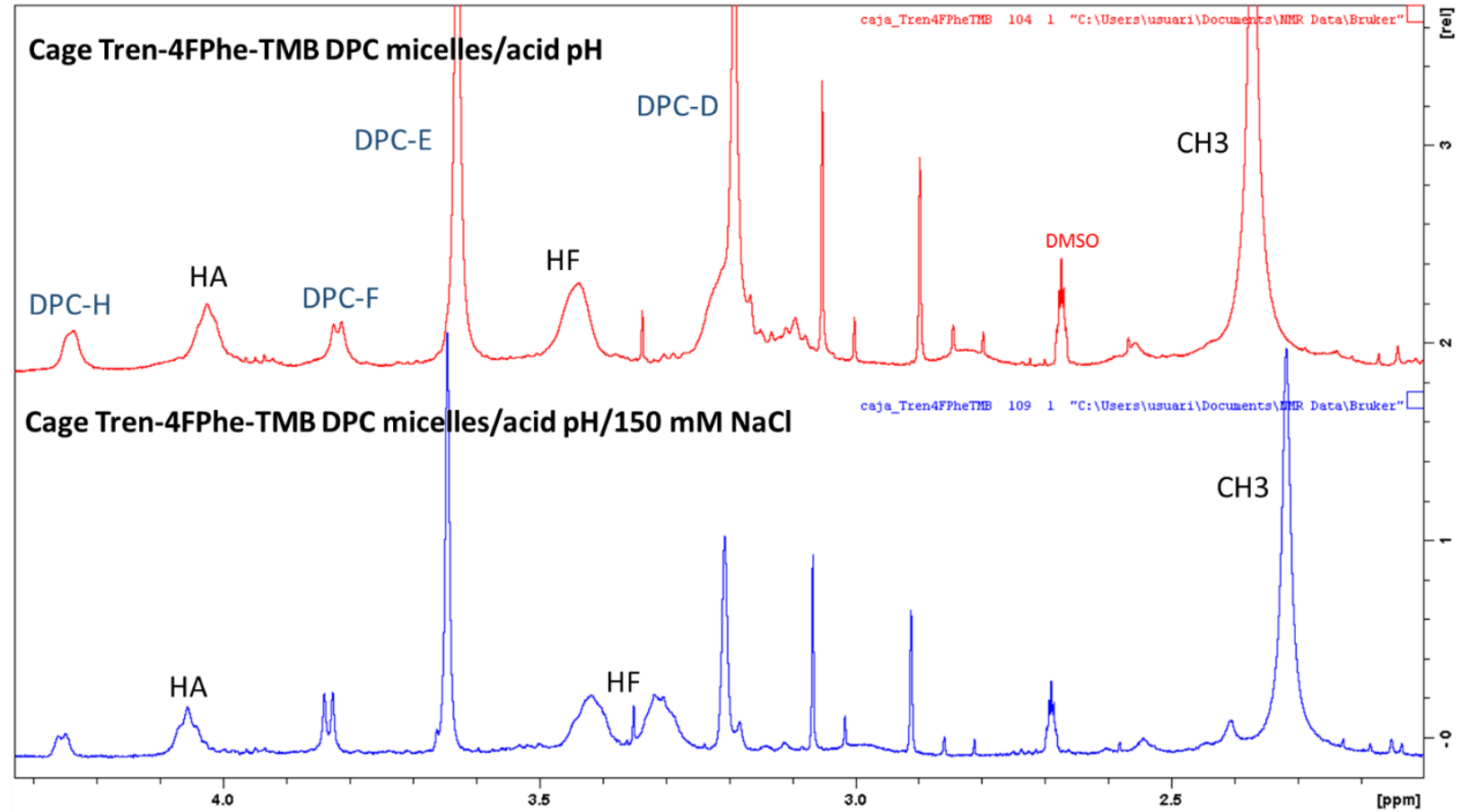

Figure S73. A comparison of the aliphatic region of ${ }^{1} \mathrm{H}$ spectra of $0.4 \mathrm{mM} 1 \mathrm{c}$ in DPC- $d 38 / \mathrm{D}_{2} \mathrm{O}$ micelles at pH 2.3-2.6 without (red spectrum) and with (blue spectrum) $150 \mathrm{mM} \mathrm{NaCl}$ 

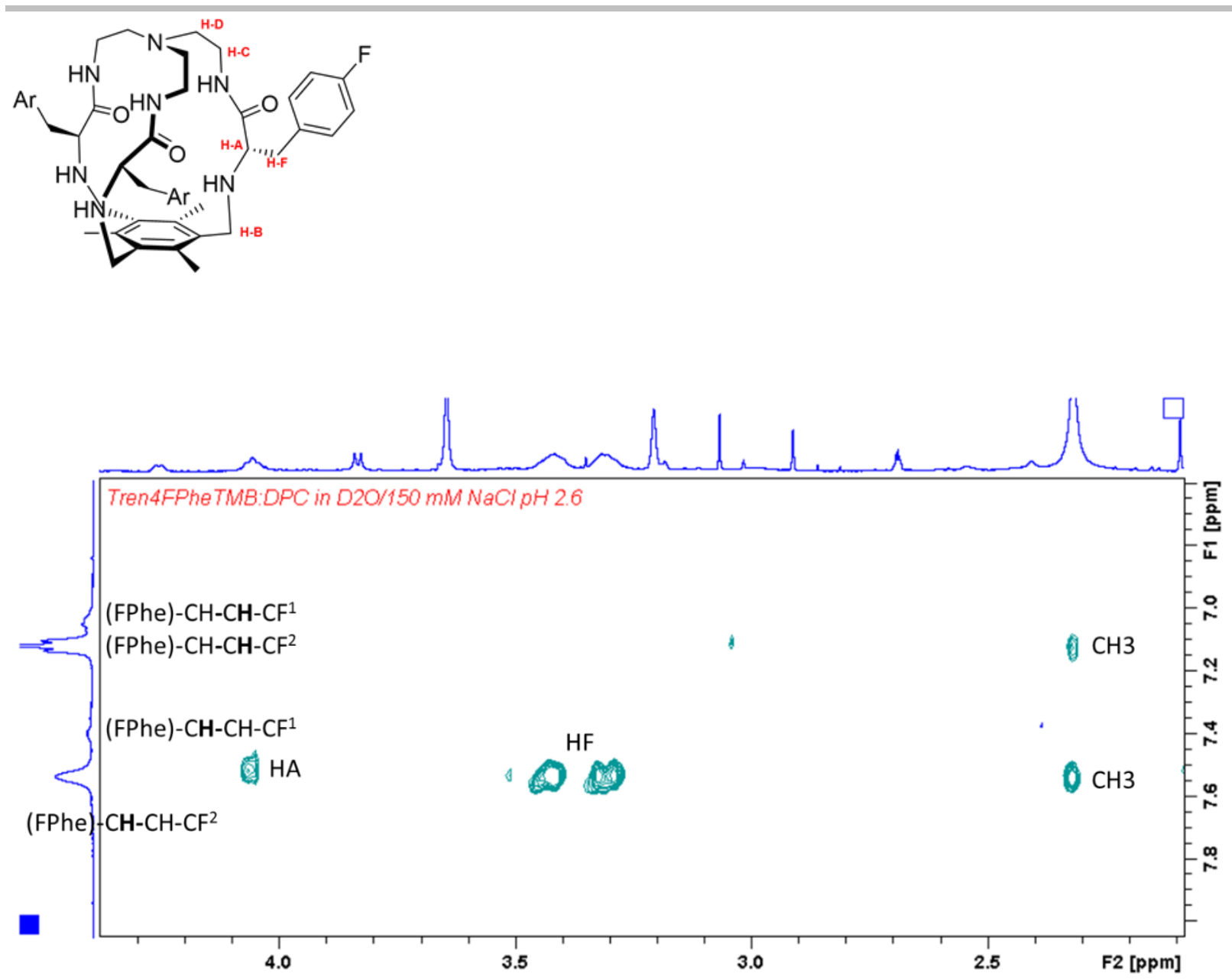

Figure S74. Part of the $2 \mathrm{D}^{1} \mathrm{H}-{ }^{1} \mathrm{H}$ ROESY spectrum (75 ms mixing time, pulse sequence roesygpph19) of $0.4 \mathrm{mM} \mathrm{1c}$ in $\mathrm{DPC}-\mathrm{d} 38 / \mathrm{D}_{2} \mathrm{O}$ micelles at acid pH with 150 $\mathrm{mM} \mathrm{NaCl}$. Superscripts 1 and 2 indicate the presence of several species in slow exchange in the chemical shift timescale (possibly 1-free and 2-chloride bound). 

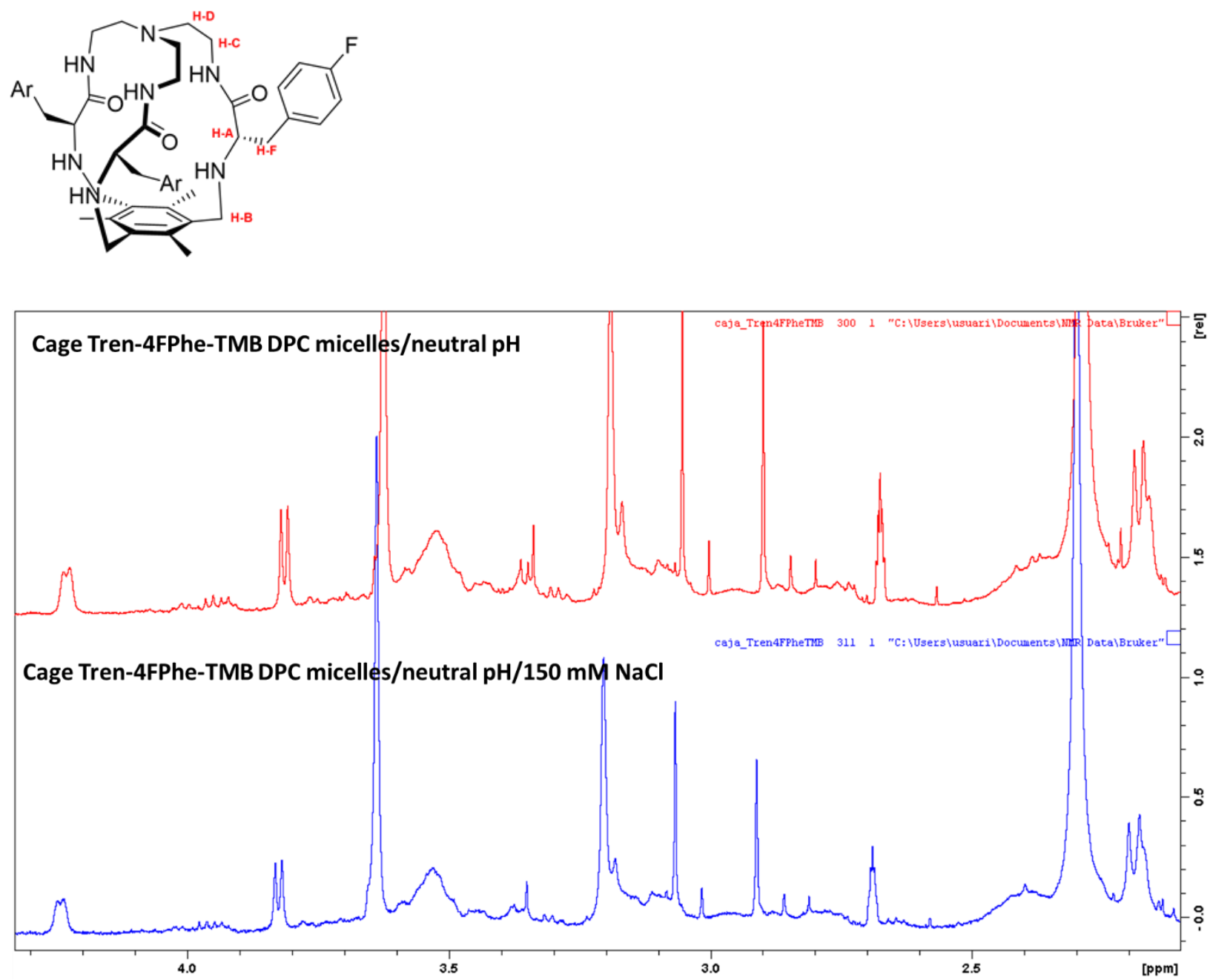

Figure S75. A comparison of the aliphatic region of ${ }^{1} \mathrm{H}$ spectra of $0.4 \mathrm{mM} 1 \mathrm{c}$ in $\mathrm{DPC}-\mathrm{d} 38 / \mathrm{D}_{2} \mathrm{O}$ micelles at $\mathrm{pH} 7.1$ without (red spectrum) and with (blue spectrum) $150 \mathrm{mM} \mathrm{NaCl}$. 

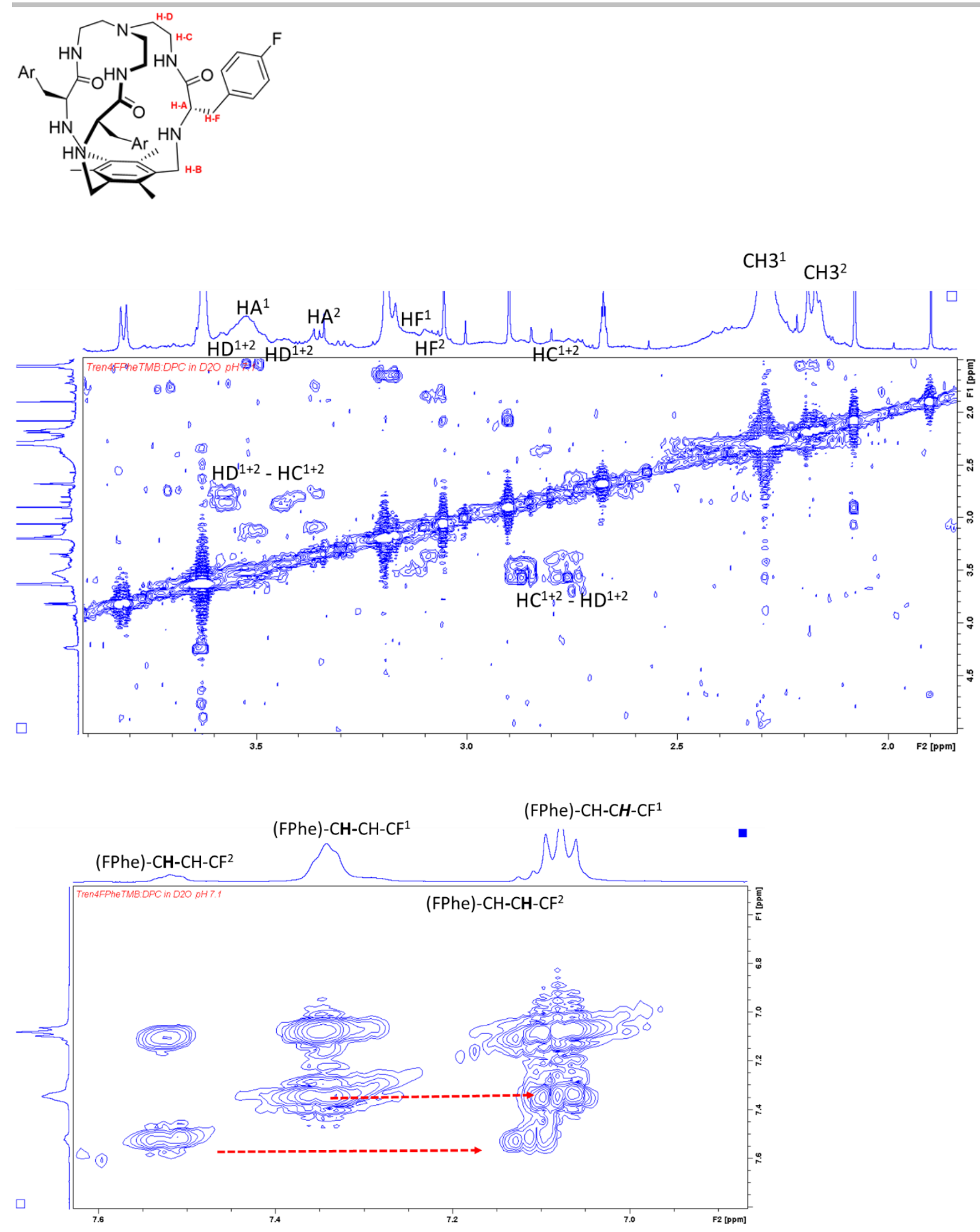

Figure S76. Parts of the $2 \mathrm{D}^{1} \mathrm{H}-{ }^{-1} \mathrm{H}$ COSY spectrum (pulse sequence cosygpprqf) of $0.4 \mathrm{mM} 1 \mathrm{c}$ in $\mathrm{DPC}-\mathrm{d} 38 / \mathrm{D}_{2} \mathrm{O}$ micelles at $\mathrm{pH} 7.1$ without salt. Superscripts 1 and 2 indicate the presence of different species in slow exchange in the chemical shift timescale. 


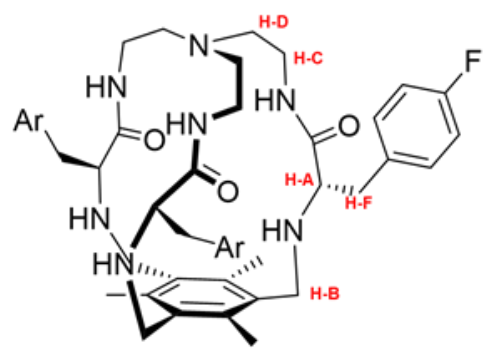

(FPhe)-CH-CH-CF ${ }^{1}$

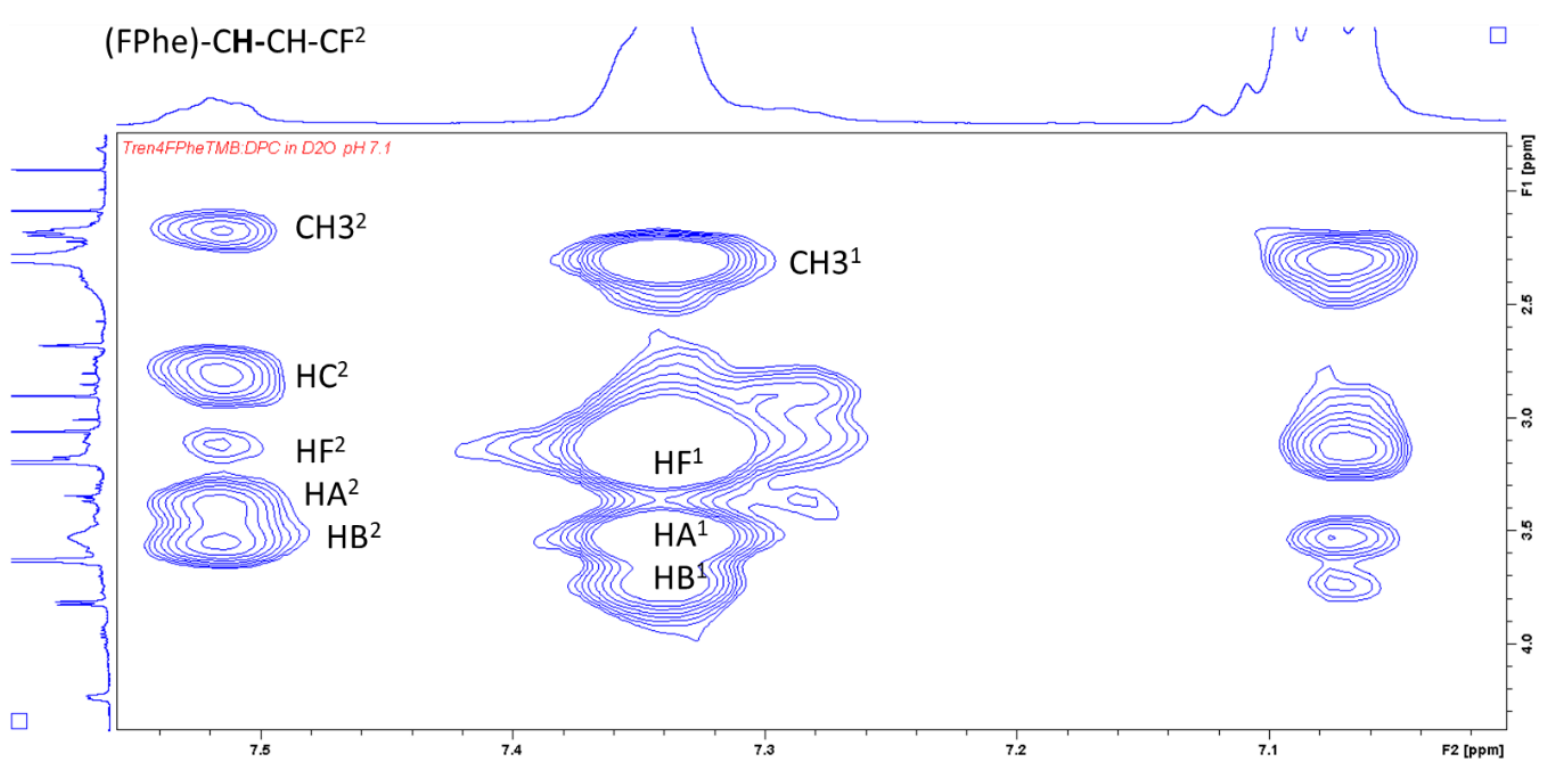

Figure S77. Part of the $2 \mathrm{D}^{1} \mathrm{H}-{ }^{1} \mathrm{H}$ NOESY spectrum (250 ms mixing time, pulse sequence noesyfpgpphwg) of $0.4 \mathrm{mM} \mathrm{1c}$ in DPC-d38/D ${ }_{2} \mathrm{O}$ micelles at pH 7.1 without salt. Superscripts 1 and 2 indicate the presence of several species in slow exchange in the chemical shift timescale. 


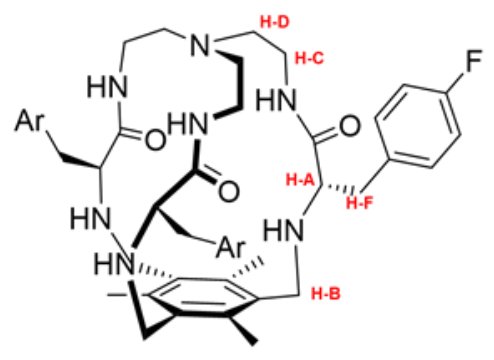

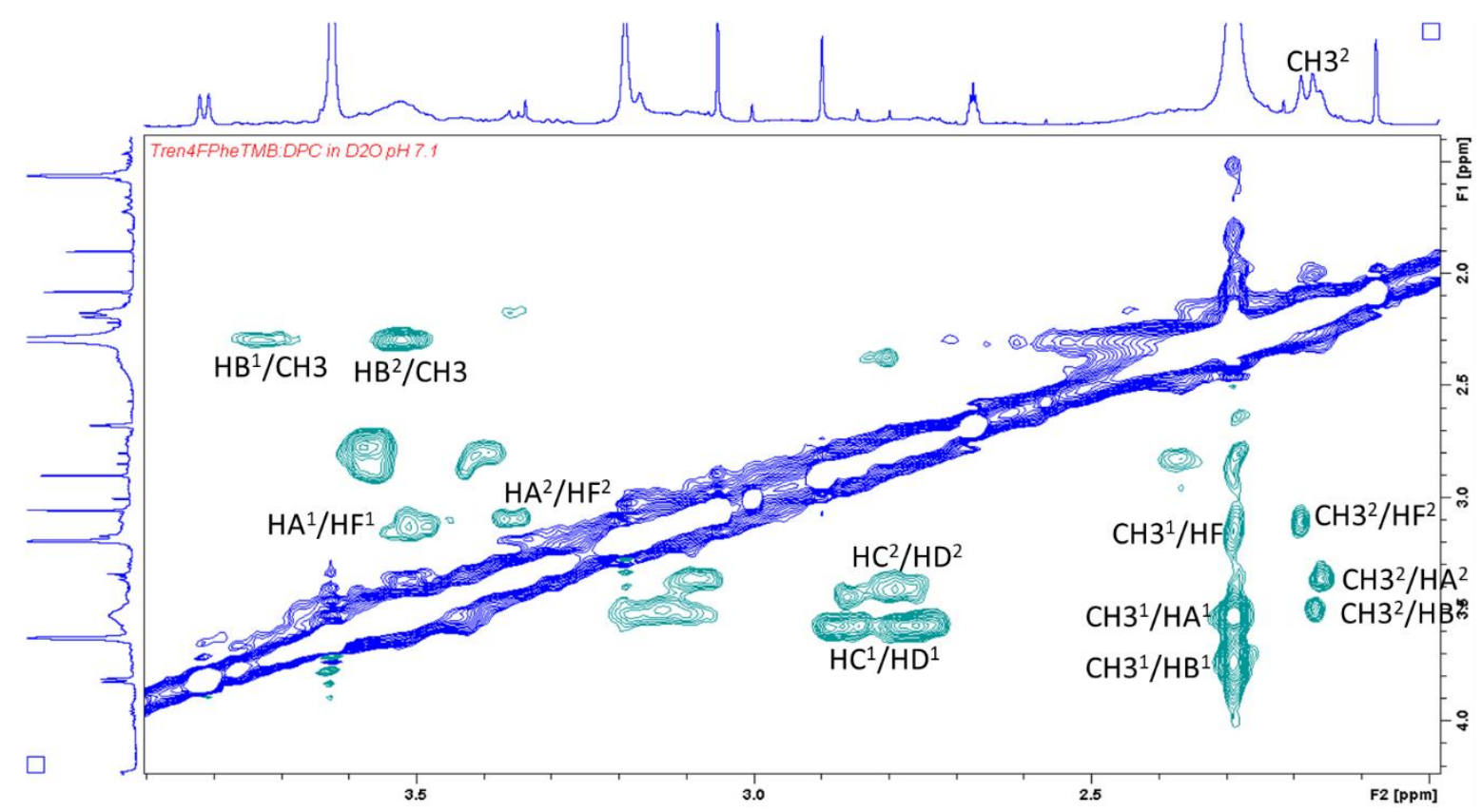

Figure S78. Part of the $2 \mathrm{D}^{1} \mathrm{H}-{ }^{1} \mathrm{H}$ ROESY spectrum (75 ms mixing time, pulse sequence roesygpph19) of $0.4 \mathrm{mM} 1 \mathrm{c}$ in $\mathrm{DPC}-\mathrm{d} 38 / \mathrm{D}_{2} \mathrm{O}$ micelles at pH 7.1 without salt. Superscripts 1 and 2 indicate the presence of several species in slow exchange in the chemical shift timescale. 


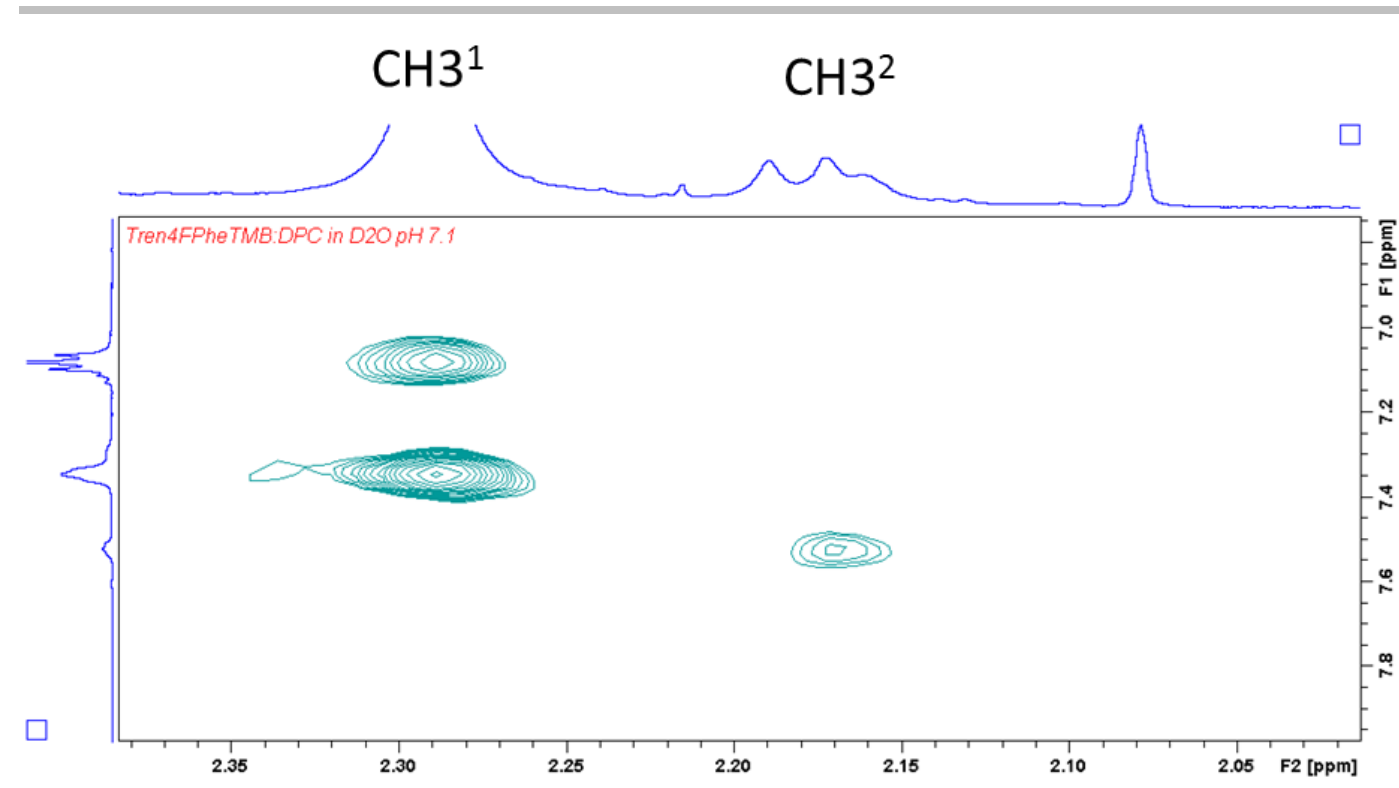

$\mathrm{CH}^{1}$

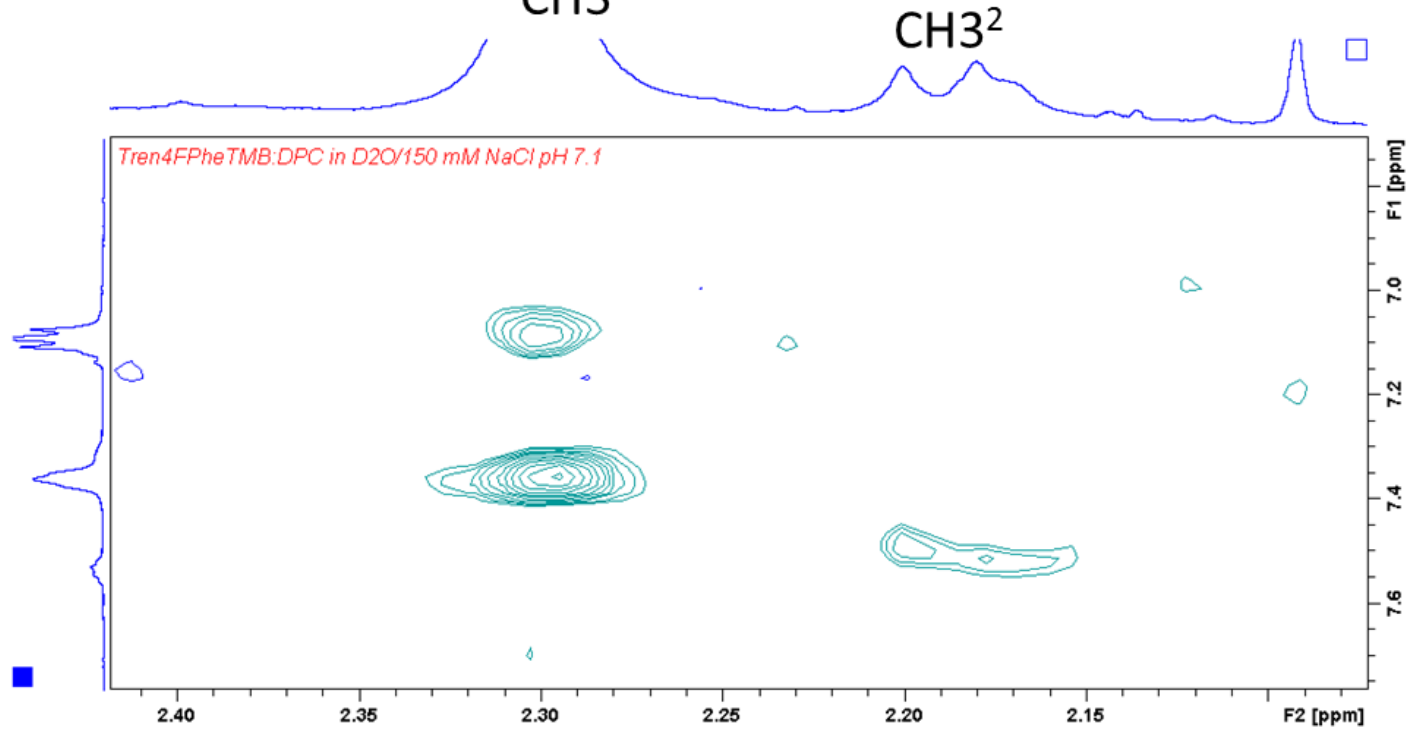

Figure S79. Part of the $2 \mathrm{D}{ }^{1} \mathrm{H}-{ }^{1} \mathrm{H}$ ROESY spectrum (75 ms mixing time, pulse sequence roesygpph19) of $0.4 \mathrm{mM} \mathrm{1c}$ in $\mathrm{DPC}-\mathrm{d} 38 / \mathrm{D}_{2} \mathrm{O}$ micelles at pH 7.1 without salt (above) and with $150 \mathrm{mM} \mathrm{NaCl}$ (below). Superscripts 1 and 2 indicate the presence of several species in slow exchange in the chemical shift timescale. 


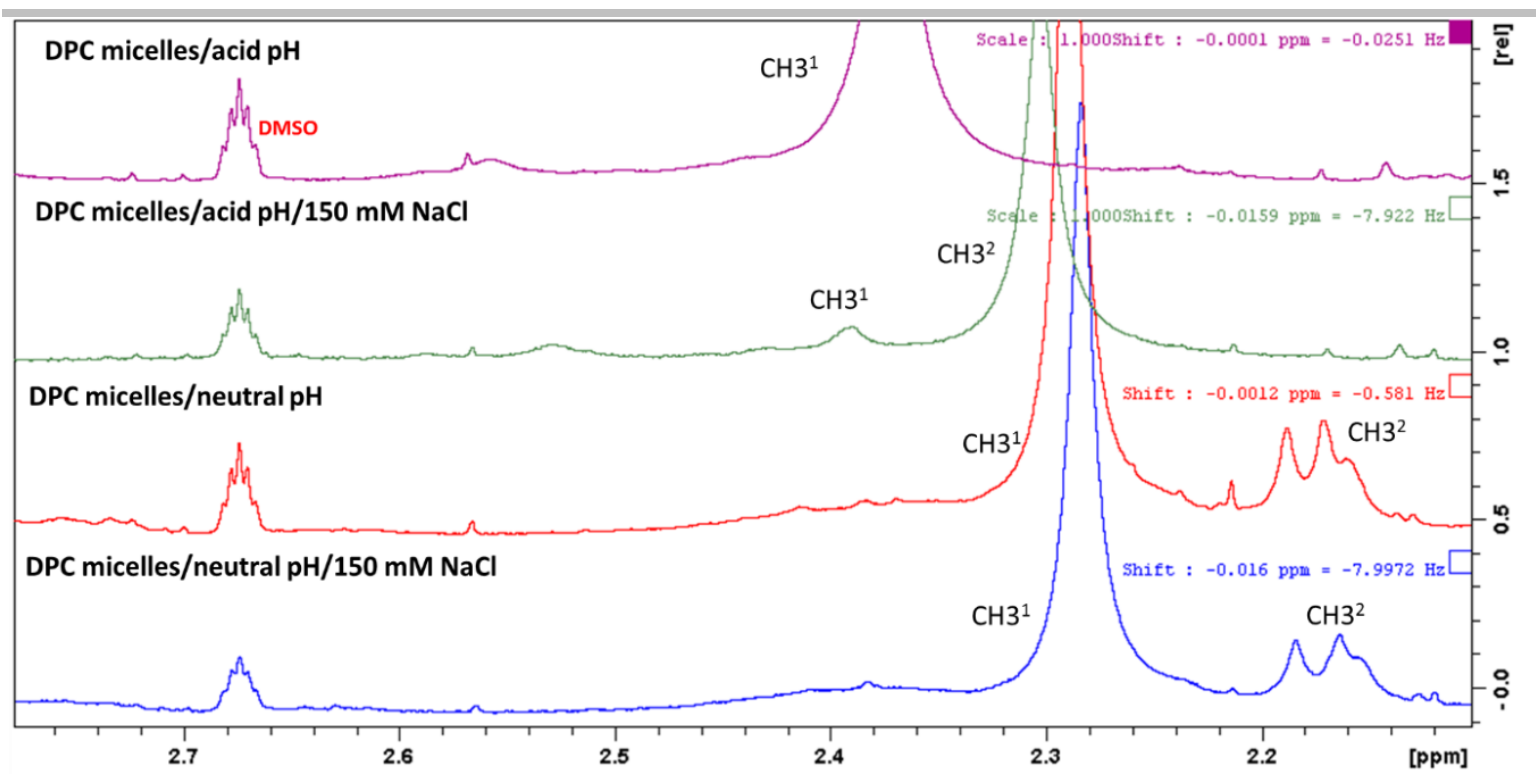

Figure S80. Methyl region of the ${ }^{1} \mathrm{H}$ spectra of $0.4 \mathrm{mM} \mathrm{1c}$ in DPC-d38/D $\mathrm{D}_{2} \mathrm{O}$ micelles at acid/neutral pH and without/with salt. For comparison purposes, the small differences in DPC/cage resonances chemical shift due to presence of salt or different $\mathrm{pH}$ 's are corrected using the DMSO-d5 residual resonance as chemical shift reference at $2.674 \mathrm{ppm}$.

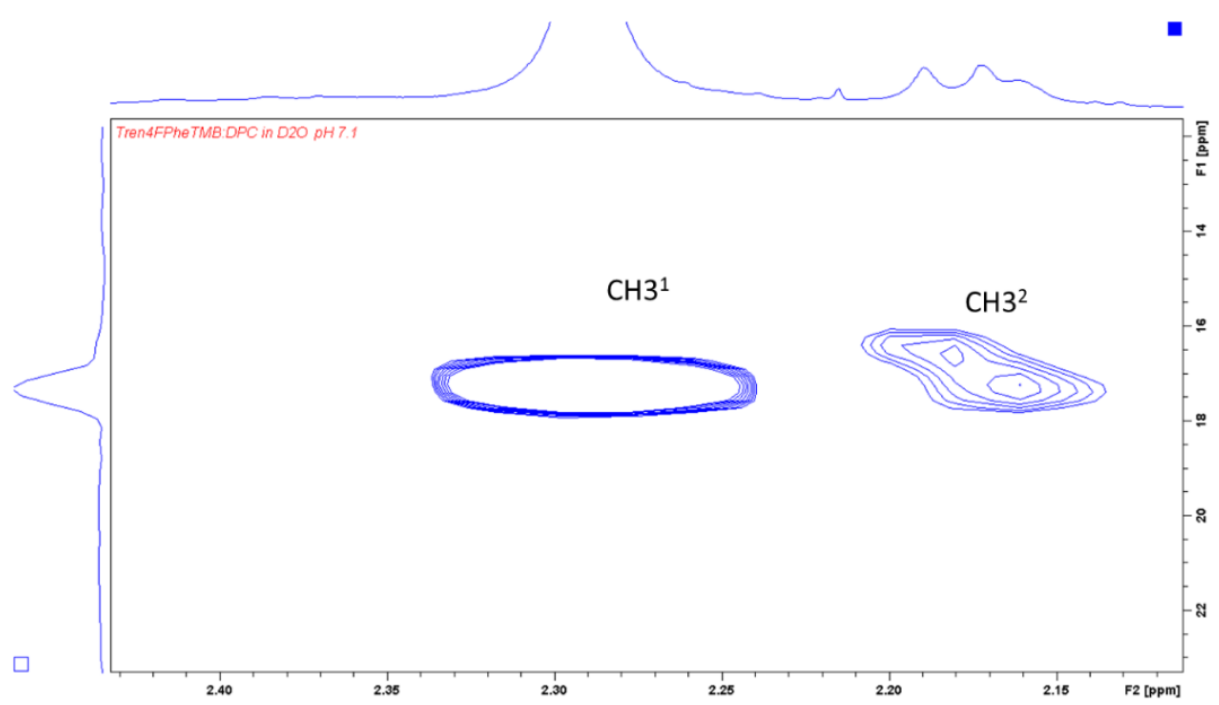

Figure S81. Methyl region of the ${ }^{1} \mathrm{H}-{ }^{13} \mathrm{C} H S Q C$ spectrum of $0.4 \mathrm{mM} 1 \mathrm{c}$ in $\mathrm{DPC}-\mathrm{d} 38 / \mathrm{D}_{2} \mathrm{O}$ micelles at neutral pH without salt.

For the sample of $1 \mathrm{c}$ in DPC- $d 38 / \mathrm{D}_{2} \mathrm{O}$ micelles at acid $\mathrm{pH}$ in the presence of $150 \mathrm{mM}$ salt, we observed two groups of resonances for the methyl protons in slow exchange, $\mathrm{CH}_{3}{ }^{1}$ and $\mathrm{CH}_{3}{ }^{2}$, corresponding to free (minor) and chloride-bound cage (major), respectively (see figure S80). For $1 \mathrm{c}$ in DPC-d38/ $\mathrm{D}_{2} \mathrm{O}$ micelles at neutral $\mathrm{pH}$, we also observed two groups of resonances for the cage methyl protons with and without salt, $\mathrm{CH}_{3}{ }^{1}$ and $\mathrm{CH}_{3}{ }^{2}$. In this case, we propose that the minor species (2-superscript) corresponds to $\mathrm{HCl}$-bound 1c, in much lower concentration at neutral $\mathrm{pH}$. 
$\mathrm{pH} 7.1,150 \mathrm{mM} \mathrm{NaCl}, \mathrm{mix}=75 \mathrm{~ms}$

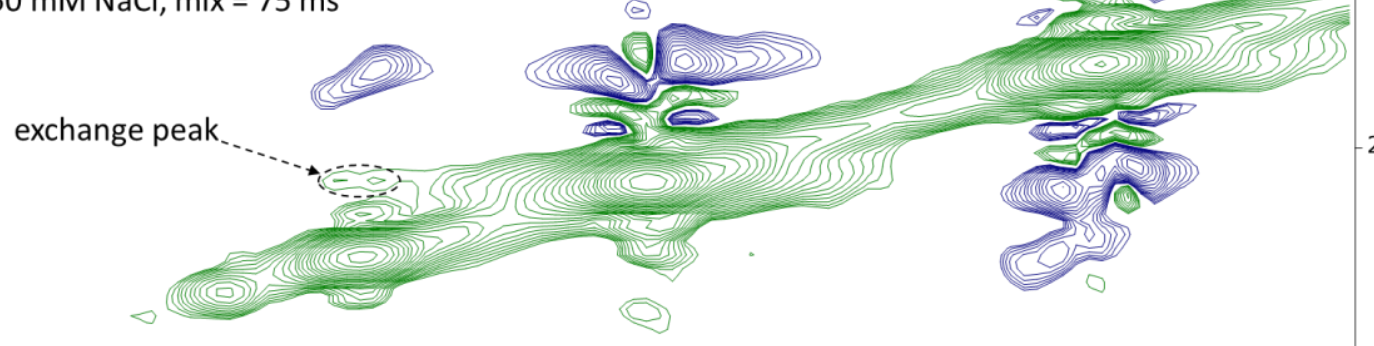

$\mathrm{pH} 2.5,150 \mathrm{mM} \mathrm{NaCl}, \mathrm{mix}=75 \mathrm{~ms}$

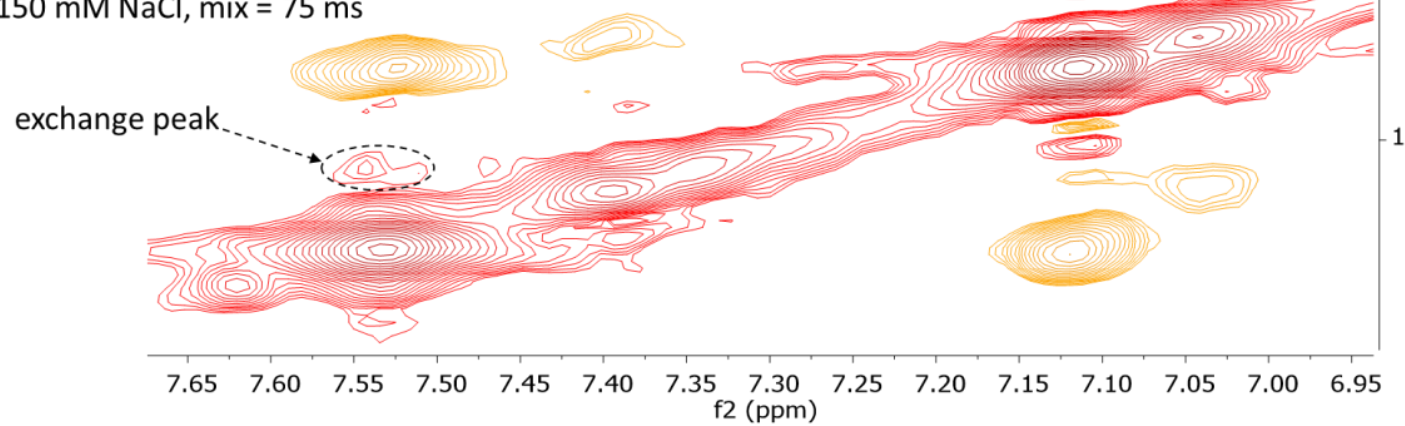

Figure S82. Comparison of the $2 \mathrm{D}^{1} \mathrm{H}-{ }^{1} \mathrm{H}$ ROESY spectra of $0.4 \mathrm{mM} 1 \mathrm{c}$ in $\mathrm{DPC}-\mathrm{d} 38 / \mathrm{D}_{2} \mathrm{O} / 150 \mathrm{mM} \mathrm{NaCl}$ micelles at neutral and acid pH. Exchange resonances for $4 \mathrm{FPhe}$ ortho protons between the two observed species (free and chloride-bound) are indicated. 


\section{Cell cultures}

Human lung adenocarcinoma cells, A549 were maintained in Dulbecco's modified eagle's medium (DMEM; Gibco Thermo Fisher Scientific, USA) with carbonate buffer. Cells were kept in the logarithmic growth phase by routine passage every $2-3$ days using $0.025 \%$ trypsin-EDTA treatment.

$\mathrm{pH} 7.2$ and 6.2 media were prepared replacing the carbonate by PIPES buffer (10 mM) and adjusting the $\mathrm{pH}$ with $\mathrm{HCl}$ or $\mathrm{NaOH}$. $\mathrm{pH} 7.6$ media (with carbonate buffer) is the same used for cell growth.

\section{Cytotoxicity vs cancer cells}

The antiproliferative activity of compounds 1a-e was evaluated using the MTT assay method. Cells were seeded 24 hours prior to treatment in 96 -well plate $\left(100 \mu \mathrm{L}\right.$ of a suspension $\left.2.5 \cdot 10^{5} \mathrm{cell} / \mathrm{mL}\right)$. The following day, culture media from the wells was replaced by $100 \mu \mathrm{L}$ of fresh media at each $\mathrm{pH}$ containing the desired concentration of the compound to be tested. All the compounds were previously dissolved in DMSO at a concentration of $20 \mathrm{mM}$. The final concentration of DMSO used in the corresponding wells did not exceeded $1 \%(\mathrm{v} / \mathrm{v})$. This concentration does not affect cell viability. Negative control cultures received the same concentration of solvent alone. Cells were incubated for $24 \mathrm{~h}$ in the presence of compounds $1 \mathrm{a}-1 \mathrm{e}$ at $37^{\circ} \mathrm{C}$ in a humidified atmosphere with $5 \% \mathrm{CO}_{2}$. At the end of incubation, culture media was removed and $100 \mu \mathrm{L}$ of MTT solution $(5 \mathrm{mg} / \mathrm{mL}$ diluted with plain culture media $1: 5)$ was added to each well and incubated for 4 hours. Afterwards, MTT solution was discarded. The purple formazan crystal formed at the bottom of the wells was dissolved with $100 \mu \mathrm{L}$ of DMSO and stirred for 30 minutes at room temperature. The absorbance at $570 \mathrm{~nm}$ was read on a spectrophotometer plate reader. The proportion of surviving cells was calculated as Absorbance of treated sample/ Absorbance of control x 100. Dose-response curves were constructed to obtain $\mathrm{IC}_{50}$ values using Origin dose-response fitting function. All experimental data were derived from at least 3 independent experiments.

Control cells were grown in the same conditions (same cell culture media, buffer and $\mathrm{pH}$ ) as treated cells to ensure that the difference in viability is only associated to the corresponding cages and not the buffer or the $\mathrm{pH}$ of the medium.

In order to ensure the suitability of PIPES buffer in the experimental conditions (10 mM, 24h incubation) pH of the media with PIPES at both $\mathrm{pH} 7.2$ and 6.2 was measured before incubation, and after 24 hours incubation with A549 cancer cells in the presence of the cages. The corresponding $\mathrm{pH}$ changes in all the cases were lower than $0.12 \mathrm{pH}$ units so we concluded that this buffer concentration was enough to maintain the extracellular $\mathrm{pH}$ constant during the experiment.

The antiproliferative activity of compound 1c in DPBS with different concentrations of chloride in the buffer was carried out as follows: Cells were seeded 24 hours prior to treatment in 96-well plate $\left(100 \mu \mathrm{L}\right.$ of a suspension $\left.2.5 \cdot 10^{5} \mathrm{cell} / \mathrm{mL}\right)$. The following day, culture media from the wells was replaced by $100 \mu \mathrm{L}$ of fresh DPBS with the desired concentration of chloride and previously adjusted to $\mathrm{pH}$ 6.4 containing different concentrations of compound 1c (from the $20 \mathrm{mM}$ stock solution in DMSO). Negative control cultures received the same concentration of solvent alone. The rest of the assay was carried out as described for the previous MTT assays. The DPBS solutions with different concentrations of chloride were prepared by replacing $\mathrm{NaCl}$ with sodium gluconate. $\mathrm{pH}$ was adjusted before each experiment to 6.4 by adding $\mathrm{NaOH}$ or $\mathrm{HCl}$.

Statistical analysis: GraphPad Prism v5.0 software (GraphPad Software Inc., La Jolla, USA) was used for statistical analysis. For all experiments, the obtained results of the triplicates were represented as means with standard deviation (SD). 


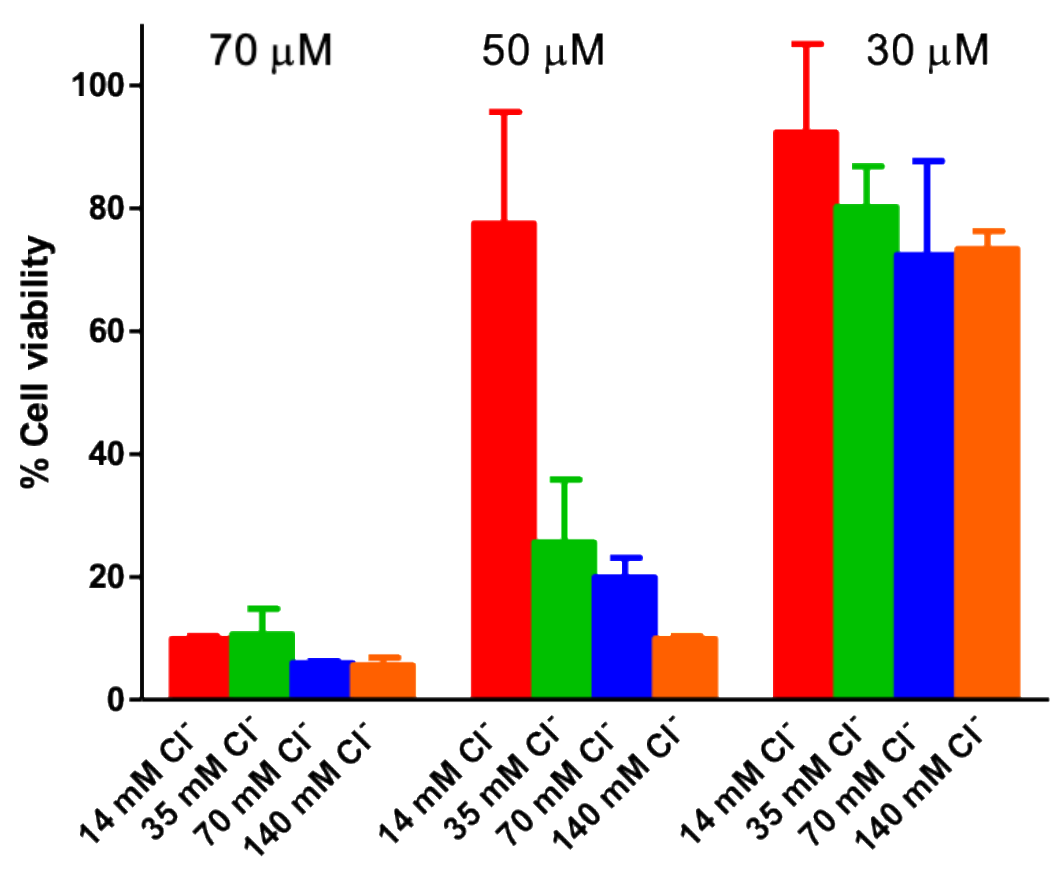

Figure S83. Cytotoxicity of compound $1 \mathrm{c}(70,50$ and $30 \mu \mathrm{M})$ towards A549 cells determined by the MTT assay after $24 \mathrm{~h}$ of incubation in DPBS containing different concentrations of chloride $(14,35,70,140 \mathrm{mM})$ at $\mathrm{pH} 6.4$. The cell viabilities were calculated considering their respective negative controls.

\section{Author Contributions}

L. Tapia synthesized all the compounds and carried out most of the experimental part of the work, she also analyzed the data and compiled the results. Y. Pérez acquired the NMR spectra for the titrations and all the experiments regarding the characterization of 1c in DPC micelles (design and preparation of the samples, acquisition of the spectra and analysis of the data). M. Bolte performed the $\mathrm{X}$-ray diffraction studies and resolved the corresponding structures. J. Casas participated in the design of the cell-culture assays. J. Solà participated in the synthetic work and in the design of the project. R. Quesada designed the chloride transport experiments in liposomes and tutored L. Tapia for their performance. I. Alfonso conceived and coordinated the whole project, guided L. Tapia throughout the study, analyzed the data and wrote the first version of the draft. All the authors participated in the writing of the last version of the manuscript. All the authors read and approved the final version of the manuscript. 